\title{
Aspectos bioquímicos e moleculares da resistência sistêmica adquirida em cafeeiro contra Hemileia vastatrix
}

\author{
SYLVIA DIAS GUZZO
}

\begin{abstract}
Tese apresentada ao Centro de Energia Nuclear na Agricultura, Universidade de São Paulo, para obtenção do título de Doutor em Ciências, Área de Concentração: Energia Nuclear na Agricultura.
\end{abstract}

\footnotetext{
P I R A C I C A B A

Estado de São Paulo - Brasil

Junho - 2004
} 


\title{
Aspectos bioquímicos e moleculares da resistência sistêmica adquirida em cafeeiro contra Hemileia vastatrix
}

\author{
SYLVIA DIAS GUZZO \\ Química \\ Orientador: Profa. Dra. SIU MUI TSAI \\ Co-orientador: Dr. RICARDO HARAKAVA
}

Tese apresentada ao Centro de Energia Nuclear na

Agricultura, Universidade de São Paulo, para obtenção do título de Doutor em Ciências, Área de Concentração: Energia Nuclear na Agricultura.

\author{
P I R A C I C A B A \\ Estado de São Paulo - Brasil \\ Junho - 2004
}


Dados Internacionais de Catalogação na Publicação (CIP) Seção Técnica de Biblioteca - CENA/USP

Guzzo, Sylvia Dias

Aspectos bioquímicos e moleculares da resistência sistêmica adquirida em cafeeiro contra Hemileia vastatrix / Sylvia Dias Guzzo. Piracicaba, 2004.

236p.: il.

Tese - (doutorado) - Centro de Energia Nuclear na Agricultura, 2004.

1. Biologia molecular vegetal 2. DNA complementar 3. Interação planta-patógeno 4. Mecanismos de defesa vegetal I. Título.

CDU 581.2:577 
A Deus

Aos meus queridos pais João (in memorian) e Maria

Às minhas irmãs e amigas

Teresa e Lilia

Ao grande amigo

Carlos Eduardo

Dedico 


\section{AGRADECIMENTOS}

À Profa. Dra. Siu Mui Tsai, pela oportunidade, confiança e orientação.

Ao Dr. Ricardo Harakava, pela orientação, sugestões, auxílio e amizade.

À minha mãe Maria, minhas irmãs Teresa e Lilia, à Paulinha, Mauro, Amanda e Gui pela amizade, incentivo e auxílio em todas as horas e demais familiares pelo apoio e carinho.

Ao grande amigo Carlos Eduardo pelo apoio constante, amizade, incentivo e paciência em todos os momentos.

À Dra. Cláudia de Mattos Bellato do CENA/USP, pelo auxílio na análise quantitativa dos resultados obtidos na metodologia de seleção diferencial.

Ao Dr. Oliveiro Guerreiro Filho do Centro de Análise e Pesquisa Tecnológica do Agronegócio do Café “Alcides Carvalho” do Instituto Agronômico, pelo fornecimento das mudas de cafeeiro Híbrido de Timor.

À Dra. Natália A.R. Peres da Universidade da Flórida, GCREC - Dover, pelas sugestões e auxílio na confecção dos gráficos.

À Marília R.G. Henyei, diretora da Biblioteca do CENA/USP, pela revisão das referências bibliográficas.

Aos professores, funcionários e colegas do CENA/USP pela formação e auxílio.

Ao Celso Bezerra de Jesus, do Laboratório de Bioquímica Fitopatológica do Centro de Pesquisa e Desenvolvimento de Sanidade Vegetal (CPDSV) do Instituto Biológico, pelo auxílio na coleta de urediniosporos da ferrugem do cafeeiro e manutenção das plantas de café. 
À Dra. Cleusa M.M. Lucon, do Laboratório de Bioquímica Fitopatológica-CPDSV do Instituto Biológico, pelo auxílio nos experimentos de indução de resistência.

À Clarice Oliveira de Jesus e a Milena Apetito Akamatsu do Laboratório de Bioquímica Fitopatológica do Instituto Biológico, pelo auxílio na execução dos minipreps e seqüenciamento.

Às amigas Heloísa, Darcy, Paula, Timinha e Yolanda pelo apoio e amizade.

Às amigas Alice, Letícia, Thais, Clarice, Milena, Elza, Júlia, Cleusa e Denise, pelo companheirismo, carinho, apoio e incentivo e aos demais colegas e funcionários do Instituto Biológico.

À Cooperativa dos Cafeicultores de Garça, SP (GARCAFÉ), pelo fornecimento de sementes de cafeeiro Mundo Novo. 


\section{SUMÁRIO}

Página

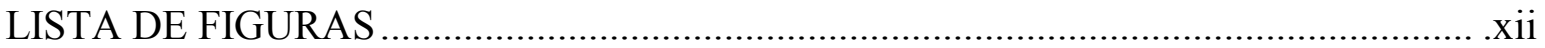

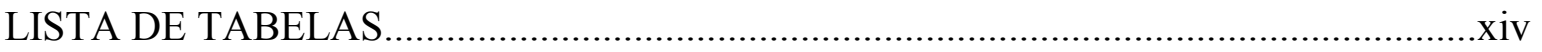

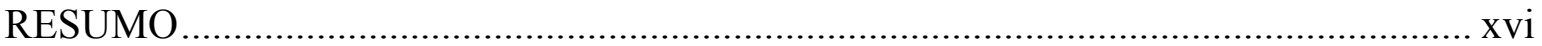

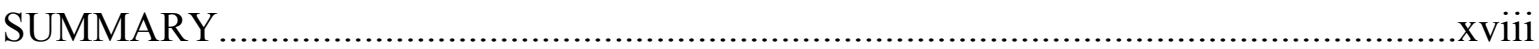

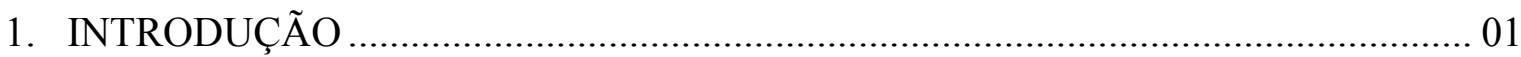



2.1. Considerações gerais sobre a interação Coffea arabica - Hemileia vastatrix....... 05



2.3. Ativação da expressão de genes de resistência ................................................ 25

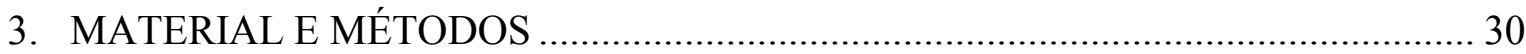

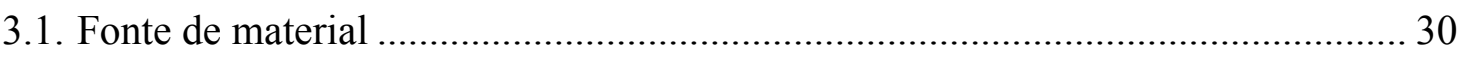

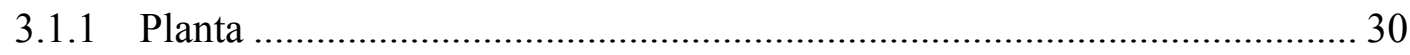

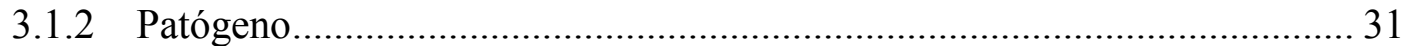

3.2 Determinação da resistência sistêmica adquirida em cafeeiro suscetível cv. Mundo

Novo contra $H$. vastatrix .......................................................................... 31

3.2.1 Obtenção do indutor de resistência ......................................................... 31

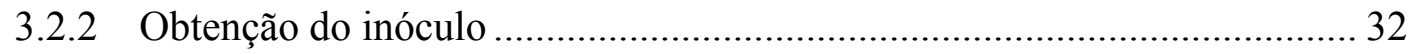

3.2.3 Indução de resistência local e sistêmica em cv. suscetível Mundo Novo



3.2.4 Inoculação das plantas com o patógeno e avaliação da indução de resistência local e sistêmica .............................................................................. 33

3.2.5 Extração de proteínas relacionadas à patogênese ....................................... 33

3.2.6 Quantificação de proteínas totais .......................................................... 34 
3.2.7 Ensaio enzimático para a determinação da atividade de quitinase 35

3.2.8 Ensaio enzimático para a determinação da atividade de $\beta$-1,3-glucanase .. 36

3.3 Isolamento de genes de cafeeiro cv. Mundo Novo, associados à resistência

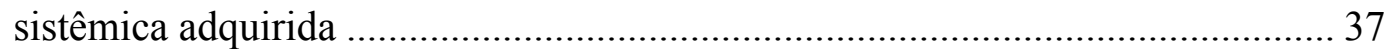

3.3.1 Tratamento das plantas com o indutor de resistência .............................. 37

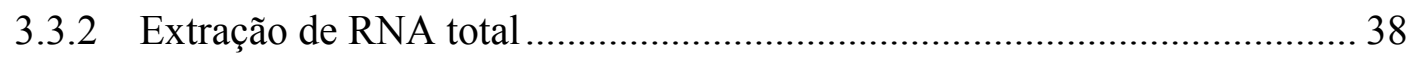

3.3.3 Síntese de DNA complementar (cDNA) ................................................... 39

3.3.3.1 Síntese da primeira fita de cDNA .............................................. 41

3.3.3.2 Síntese da segunda fita de cDna pela reação em cadeia da polimerase à longa distância (LD PCR) ............................................................... 41

3.3.3.3 Purificação do cDNA dupla fita..................................................... 42

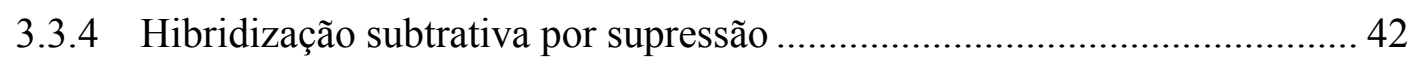

3.3.4.1 Digestão dos cDNAs com a enzima de restrição Rsa I....................... 45

3.3.4.2 Ligação de adaptadores ao cDNA proveniente de plantas induzidas ... 45

3.3.4.3 Primeira reação de hibridização....................................................... 46

3.3.4.4 Segunda reação de hibridização ..................................................... 47

3.3.4.5 Primeira amplificação do produto da hibridização pela reação em cadeia

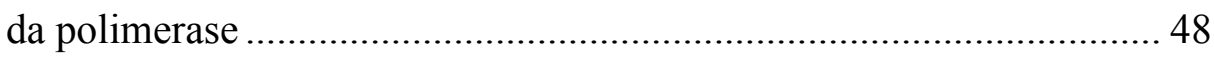

3.3.4.6 Segunda amplificação pela reação em cadeia da polimerase............... 49

3.3.5 Clonagem do produto final da hibridização subtrativa por supressão no vetor

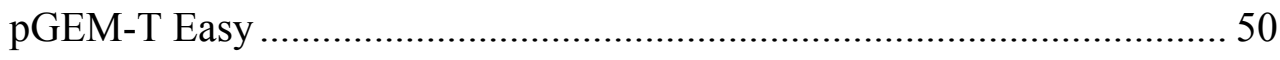

3.3.6 Transformação por eletroporação em células competentes de Escherichia



3.3.7 Extração dos plasmídeos dos clones obtidos .......................................... 52

3.3.8 Seqüenciamento dos plasmídeos da mini-biblioteca de cDNA de genes obtidos de plantas induzidas ................................................................... 53

3.3.9 Avaliação da função dos genes isolados de cafeeiro Mundo Novo tratado com indutor de resistência

3.3.10 Confirmação da ativação da expressão de genes na planta induzida, por seleção diferencial 
3.3.10.1 Desnaturação com hidróxido de sódio dos cDNAs da biblioteca subtraída

3.3.10.2 Fixação por ultravioleta, dos cDNAs aplicados às membranas de

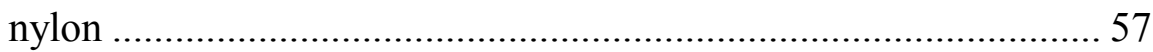

3.3.10.3 Preparo e marcação das sondas de cDNAs com digoxigenina ....... 58

3.3.10.4 Pré-hibridização dos cDNAs....................................................5

3.3.10.5 Hibridização dos cDNAs presentes nas membranas com as sondas marcadas

3.3.10.6 Revelação das membranas após a hibridização por

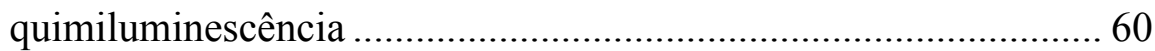

3.3.10.7 Revelação dos filmes de raios X............................................... 61

3.4 Isolamento de genes de cafeeiro Híbrido de Timor associados à resistência contra a

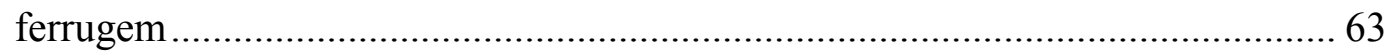

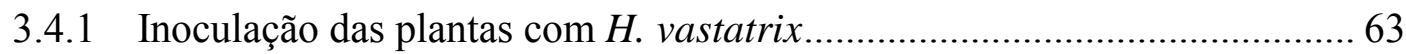

3.4.2 Certificação da resistência do cafeeiro Híbrido de Timor contra $H$. vastatrix

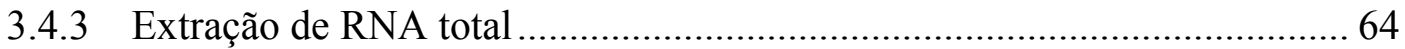

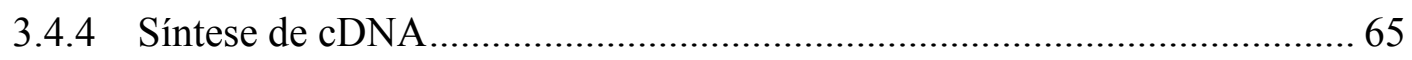

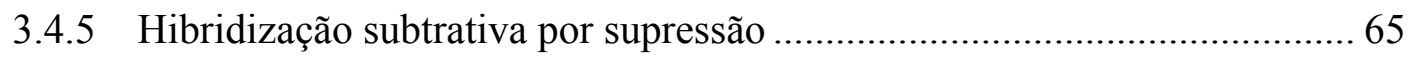

3.4.6 Clonagem e seqüenciamento dos plasmídeos da mini-biblioteca de cDNA de

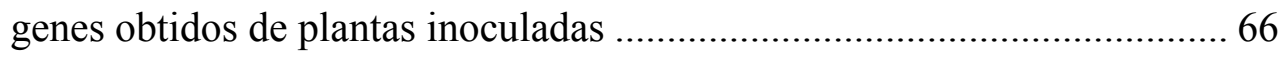

3.4.7 Avaliação da função dos genes isolados de cafeeiro Híbrido de Timor inoculado com $H$. vastatrix. 67

3.4.8 Confirmação por seleção diferencial da expressão de genes ativados em cafeeiro Híbrido de Timor após inoculação com $H$. vastatrix.

3.5 Isolamento de cDNAs dos genes codificadores de $\beta$-1,3-glucanase de cafeeiro cv. Mundo Novo e de Híbrido de Timor 68

3.5.1 Síntese dos primers para amplificação dos cDNAs dos genes de $\beta$-1,3glucanase de cafeeiro cv. Mundo Novo e Híbrido de Timor 69

3.5.2 Amplificação rápida das extremidades de cDNA - RACE 
3.5.2.1 Síntese das extremidades 5' e 3' dos cDNAs provenientes de plantas tratadas com indutor de resistência ou inoculadas com $H$. vastatrix .... 71

3.5.2.2 Amplificação das extremidade 5' e 3' dos cDNAs dos genes codificadores de $\beta$-1,3-glucanase pela reação em cadeia da polimerase .......... 72

3.5.2.3 Clonagem das extremidades 5' e 3' dos cDNAs de $\beta$-1,3-glucanase nos vetores pCR 4-TOPO ou pGEM-T Easy.

3.5.2.4 Digestão dos clones de cDNA codificadores de $\beta$-1,3-glucanase com a enzima EcoRI.

3.5.2.5 Seqüenciamento dos clones de cDNAs apresentando as extremidades 5' e 3' dos genes codificadores de $\beta$-1,3-glucanase .............................. 76

4.1 Determinação da resistência sistêmica adquirida em cafeeiro suscetível cv. Mundo Novo contra $H$. vastatrix 79

4.1.1 Avaliação da indução de resistência local e sistêmica em cafeeiro cv. Mundo Novo contra $H$. vastatrix.

4.1.2 Determinação das atividades de $\beta$-1,3-glucanase e quitinases em cafeeiro cv. Mundo Novo tratado com indutor de resistência.

4.2 Isolamento de genes de cafeeiro cv. Mundo Novo, associados à resistência sistêmica adquirida 85

4.2.1 Extração de RNA total de cafeeiro cv. Mundo Novo a partir de plantas controle ou tratadas com indutor de resistência.

4.2.2 Síntese de cDNA a partir de RNA extraído de plantas de café Mundo Novo controle ou tratadas com indutor de resistência..... 86

4.2.3 Isolamento por hibridização subtrativa por supressão de genes de cafeeiro Mundo Novo tratado com indutor de resistência.

4.2.4 Seqüenciamento e avaliação da função de genes isolados de cafeeiro Mundo Novo tratado com indutor de resistência .....

4.2.5 Determinação por seleção diferencial da expressão de genes ativados em cafeeiro cv. Mundo Novo após tratamento com indutor de resistência .... 111 
4.3 Isolamento de genes de cafeeiro Híbrido de Timor associados à resistência vertical

4.3.1 Certificação da resistência do cafeeiro Híbrido de Timor contra $H$. vastatrix 114

4.3.2 Isolamento por hibridização subtrativa por supressão de genes de cafeeiro Híbrido de Timor inoculado com $H$. vastatrix. 115

4.3.3 Seqüenciamento e avaliação da função de genes isolados de cafeeiro Híbrido de Timor inoculado com $H$. vastatrix

4.3.4 Determinação por seleção diferencial da expressão de genes ativados em cafeeiro Híbrido de Timor após inoculação com $H$. vastatrix 140

4.4 Comparação de genes isolados por hibridização subtrativa por supressão induzidos em cafeeiro cv. Mundo Novo após tratamento com indutor de resistência, com aqueles ativados em Híbrido de Timor em resposta à $H$. vastatrix

4.5 Isolamento de cDNAs dos genes codificadores de $\beta$-1,3-glucanases de cafeeiro cv. Mundo Novo e de Híbrido de Timor através da técnica RACE.

4.5.1 Obtenção dos clones de cDNA dos genes codificadores das $\beta$-1,3-glucanases de cafeeiro cv. Mundo Novo e de Híbrido de Timor e digestão com EcoRI

4.5.2 Determinação das seqüências completas dos cDNAs dos genes codificadores de $\beta$-1,3-glucanases de cafeeiro cv. Mundo Novo e de Híbrido de Timor

5.1 Resistência sistêmica adquirida em cafeeiro contra $H$. vastatrix e indução local e sistêmica de quitinases e $\beta$-1,3-glucanases por acibenzolar-S-metil

5.2 Genes de cafeeiro cv. Mundo Novo, associados à resistência sistêmica adquirida e de cafeeiro Híbrido de Timor associados à resistência vertical

5.2.1 Genes isolados de cafeeiro cv. Mundo Novo tratado com o indutor de resistência acibenzolar-S-metil

5.2.2 Genes isolados de cafeeiro cv. Híbrido de Timor inoculado com o patógeno H. vastatrix. 
5.2.3 Determinação por seleção diferencial da expressão de genes ativados em cafeeiro cv. Mundo Novo após tratamento com ASM e em Híbrido de Timor, após inoculação com $H$. vastatrix

5.2.4 Comparação de genes isolados por HSS induzidos em cafeeiro cv. Mundo Novo após tratamento com o indutor de resistência, com aqueles ativados em Híbrido de Timor em resposta à $H$. vastatrix.................................... 195



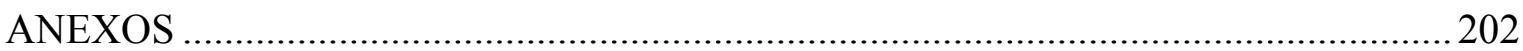

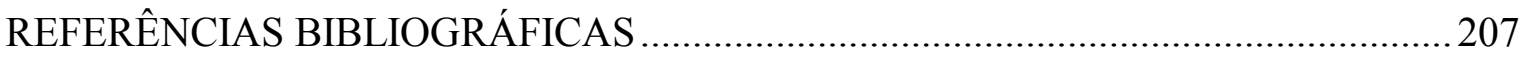




\section{LISTA DE FIGURAS}

Página

Figura 1 Representação diagramática da síntese de cDNA com o kit SMART............ 40

Figura 2 Representação diagramática da hibridização subtrativa por supressão............ 44

Figura 3 Indução local e sistêmica de quitinases e $\beta$-1,3-glucanases em folhas de cafeeiro suscetíveis cv. Mundo Novo, protegidos contra $H$. vastatrix por acibenzolar-Smetil (ASM) 84

Figura 4 Eletroforese em gel de agarose $(0,8 \%)$ de RNA total extraído de cafeeiro cv. Mundo Novo antes e após o tratamento com acibenzolar-S-metil (ASM) ...... 85

Figura 5 Eletroforese em gel de agarose $(1,2 \%)$ de cDNA sintetizado a partir de RNA total extraído de cafeeiro cv. Mundo Novo antes e após o tratamento das plantas com acibenzolar-S-metil (ASM)

Figura 6 Eletroforese em gel de agarose (1,5\%) de cDNAs obtidos após hibridização subtrativa por supressão (HSS) e amplificação por PCR, provenientes de plantas de café cv. Mundo Novo, tratadas com o ASM ou com água 88

Figura 7 Eletroforese em gel de agarose $(1,5 \%)$ do produto do segundo PCR da hibridização subtrativa por supressão (HSS), antes e após purificação, proveniente de plantas de café cv. Mundo Novo, tratadas com o ASM

Figura 8 Seleção diferencial dos clones de cDNA da biblioteca subtraída de cafeeiro cv. Mundo Novo tratado com acibenzolar-S-metil (ASM) 113

Figura 9 Sintomas da ferrugem alaranjada do cafeeiro em plantas de café cv. Mundo Novo e Híbrido de Timor, inoculadas com uma suspensão de urediniosporos de H. vastatrix $(2 \mathrm{mg} / \mathrm{mL})$ 114 
Figura 10 Eletroforese em gel de agarose (1,5\%) de cDNAs obtidos após hibridização subtrativa por supressão (HSS) e amplificação por PCR, provenientes de plantas de café Híbrido de Timor, inoculadas com $H$. vastatrix ou com água

Figura 11 Seleção diferencial dos clones de cDNA da biblioteca subtraída de cafeeiro Híbrido de Timor inoculado com $H$. vastatrix.....

Figura 12 Genes ativados em cafeeiro cv. Mundo Novo tratado com acibenzolar-S-metil (ASM)

Figura 13 Genes ativados em cafeeiro Híbrido de Timor inoculado com H. vastatrix.. 145

Figura 14 Genes associados à resistência sistêmica adquirida, ativados em cafeeiro cv. Mundo Novo através da aplicação de acibenzolar-S-metil (ASM)

Figura 15 Genes associados à resistência vertical ativados em cafeeiro Híbrido de Timor após inoculação com $H$. vastatrix 146

Figura 16 Eletroforese em gel de agarose (0,8\%) dos clones de cDNA dos genes codificadores das $\beta$-1,3-glucanases de cafeeiro cv. Mundo Novo e de Híbrido de Timor, após digestão com EcoRI 150

Figura 17 Representação esquemática do procedimento utilizado para obter as seqüências completas dos genes codificadores das $\beta$-1,3-glucanases de cafeeiro cv. Mundo Novo e Híbrido de Timor. 151

Figura 18 cDNA e seqüência de aminoácidos da $\beta$-1,3-glucanase de cafeeiro cv. Mundo Novo

Figura 19 cDNA e seqüência de aminoácidos da $\beta$-1,3-glucanase de cafeeiro cv. Híbrido de Timor.

Figura 20 Alinhamento de seqüências de aminoácidos da proteína $\beta$-1,3-glucanase de cafeeiro cv. Mundo Novo com aquelas de Arabidopsis, arroz e sorgo presentes no GenBank

Figura 21 Alinhamento de seqüências de aminoácidos da proteína $\beta$-1,3-glucanase de cafeeiro cv. Híbrido de Timor com aquelas de tomateiro, fumo e videira presentes no GenBank 


\section{LISTA DE TABELAS}

Página

Tabela 1 Indução de resistência local e sistêmica em plantas de café cv. Mundo Novo contra $H$. vastatrix, após diferentes intervalos de tempo do tratamento foliar com acibenzolar-S-metil

Tabela 2 Indução local e sistêmica de quitinases em plantas de café cv. Mundo Novo em diferentes intervalos de tempo após o tratamento das folhas com o indutor acibenzolar-S-metil

Tabela 3 Indução local e sistêmica de $\beta$-1,3-glucanase em plantas de café cv. Mundo Novo em diferentes intervalos de tempo, após o tratamento das folhas com o indutor acibenzolar-S-metil

Tabela 4 Genes de cafeeiro Mundo Novo tratado com ASM, envolvidos no estresse oxidativo, resposta de hipersensibilidade e/ou apoptose 92

Tabela 5 Genes isolados de cafeeiro Mundo Novo tratado com ASM, codificadores de compostos antimicrobianos

Tabela 6 Genes de cafeeiro Mundo Novo tratado com ASM, envolvidos na síntese de fitoalexinas, fenóis, flavonóides e/ou lignina e no transporte de compostos sucundários antimicrobianos.....

Tabela 7 Genes isolados de cafeeiro Mundo Novo tratado com ASM, envolvidos na síntese de compostos de baixo peso molecular com função sinalizadora de respostas de defesa

Tabela 8 Genes isolados de cafeeiro Mundo Novo tratado com ASM, envolvidos na percepção e transdução do sinal de resistência 
Tabela 9 Genes de cafeeiro Mundo Novo tratado com ASM, envolvidos no metabolismo de lipídeos

Tabela 10 Genes de cafeeiro Mundo Novo tratado com ASM, envolvidos na degradação controlada de proteínas

Tabela 11 Genes de cafeeiro Mundo Novo tratado com ASM, apresentando funções relacionadas à manutenção celular e desenvolvimento vegetal

Tabela 12 Genes de cafeeiro Híbrido de Timor inoculado com Hemileia vastatrix, envolvidos no estresse oxidativo, resposta de hipersensibilidade e/ou apoptose

Tabela 13 Genes isolados de cafeeiro Híbrido de Timor inoculado com Hemileia vastatrix, codificadores de compostos antimicrobianos

Tabela 14 Genes de cafeeiro Híbrido de Timor inoculado com Hemileia vastatrix, envolvidos na síntese de fitoalexinas, fenóis, alcalóides e/ou lignina e no transporte de compostos secundários antimicrobianos 122

Tabela 15 Genes isolados de cafeeiro Híbrido de Timor inoculado com Hemileia vastatrix, envolvidos na síntese de compostos de baixo peso molecular com função sinalizadora de respostas de defesa

Tabela 16 Genes de cafeeiro Híbrido de Timor inoculado com Hemileia vastatrix, envolvidos na percepção e transdução do sinal de resistência.

Tabela 17 Genes de cafeeiro Híbrido de Timor inoculado com Hemileia vastatrix, envolvidos no metabolismo de lipídeos

Tabela 18 Genes de cafeeiro Híbrido de Timor inoculado com Hemileia vastatrix, envolvidos na degradação controlada de proteínas....

Tabela 19 Genes de cafeeiro Híbrido de Timor inoculado com Hemileia vastatrix, apresentando funções relacionadas à manutenção celular e desenvolvimento vegetal 132

Tabela 20 Características das proteínas $\beta$-1,3-glucanases codificadas por genes isolados de cafeeiro cv. Mundo Novo e Híbrido de Timor, após tratamento com acibenzolar-S-metil ou inoculação com $H$. vastatrix, respecivamente 156 


\title{
Aspectos bioquímicos e moleculares da resistência sistêmica adquirida em cafeeiro contra Hemileia vastatrix
}

\author{
Autora: SYLVIA DIAS GUZZO \\ Orientador: Profa. Dra. SIU MUI TSAI \\ Co-orientador: Dr. RICARDO HARAKAVA
}

\section{RESUMO}

Com o propósito de contribuir para o esclarecimento dos mecanismos bioquímicos e moleculares envolvidos na resistência sistêmica adquirida (SAR) em plantas suscetíveis contra fitopatógenos, foram conduzidos estudos na interação Coffea arabica-Hemileia vastatrix.

A indução de atividade de quitinases e $\beta$-1,3-glucanases e o envolvimento dessas enzimas na resistência sistêmica adquirida contra $H$. vastatrix foram avaliados em cafeeiro suscetível cultivar Mundo Novo (MN) após o tratamento com acibenzolar-Smetil (ASM) (200 $\mu$ g de i.a./mL). O produto induziu aumento local e sistêmico das atividades de quitinases e $\beta$-1,3-glucanases nos tecidos foliares, a partir do primeiro e segundo dia da aplicação do indutor, respectivamente. As atividades enzimáticas atingiram níveis máximos de aumento nas plantas tratadas em relação ao controle, sete dias após a aplicação do ASM. Resistências local e sistêmica ao patógeno foram induzidas a partir do primeiro dia após o tratamento com ASM. A proteção e atividades enzimáticas foram detectadas até 35 dias, após aplicação do indutor. A indução de resistência local contra a ferrugem atingiu um nível máximo de 87\% entre 7 e 14 dias. 
Níveis máximos de proteção sistêmica de 53 a 68\% foram observados entre 2 e 21 dias após o tratamento de cafeeiro com o indutor. Neste intervalo de tempo foi observado, também, um aumento sistêmico máximo de atividade enzimática. Os resultados sugerem que o aumento de atividade dessas hidrolases está relacionado com a resistência local e sistêmica, induzida por ASM, em cafeeiro MN contra a ferrugem.

Genes relacionados à SAR foram identificados em cafeeiro através de hibridização subtrativa por supressão (HSS), a partir de mRNAs isolados de plantas suscetíveis cv. MN, 72 h após o tratamento com ASM (200 $\mu$ g i.a./mL). Os mecanismos de respostas de defesa associados à SAR ativada em MN foram comparados, através do isolamento de genes por HSS, com a resistência raça-cultivar específica observada no cafeeiro resistente Híbrido de Timor (HT), 72 h após a inoculação com $H$. vastatrix. Através da HSS, produziram-se duas bibliotecas de cDNAs subtraídas, enriquecidas de fragmentos de genes induzidos em MN pelo ASM (MN-ASM) ou ativados em HT pelo patógeno (HT-Hv). Os genes encontrados estão envolvidos em diversos processos relacionados à resistência contra fitopatógenos como: formação de espécies de oxigênio reativas, resposta de hipersensibilidade, morte celular programada, síntese e transporte de metabólitos antimicrobianos, percepção e transdução de sinal, síntese de proteínas relacionadas à patogênese, metabolismo de lipídeos e degradação controlada de proteínas. Foi identificado em HT-Hv um número maior de genes implicados em mecanismos de defesa (22\%), do que em MN-ASM (16\%). Na interação HT-Hv foi detectado um número maior de genes implicados na percepção e transdução de sinal (44\%), do que em MN-ASM (30\%). Entretanto, o número de genes codificadores de proteínas antimicrobianas foi maior no MN com resistência induzida (22\%), do que no cafeeiro resistente HT inoculado com o patógeno (6\%). Foram isolados de HT-Hv e MN-ASM, genes codificadores de $\beta$-1,3-glucanases e as seqüências completas puderam ser determinadas através da técnica RACE. Os resultados obtidos sugerem que a resistência em HT-Hv e MN-ASM ocorre através de mecanismos distintos. 


\title{
Biochemical and molecular aspects of systemic acquired resistance in coffee plants against Hemileia vastatrix
}

\author{
Author: SYLVIA DIAS GUZZO \\ Adviser: Prof. Dr. SIU MUI TSAI \\ Co-adviser: Dr. RICARDO HARAKAVA
}

\section{SUMMARY}

Studies on the interaction Coffea arabica-Hemileia vastatrix were performed in order to contribute to the elucidation of biochemical and molecular mechanisms involved in systemic acquired resistance (SAR) developed in susceptible plants against pathogens.

Induction of chitinase and $\beta$-1,3-glucanase activities and their involvement in systemic acquired resistance against $H$. vastatrix were evaluated in susceptible coffee plants cultivar "Mundo Novo” (MN) after treatment with acibenzolar-S-methyl (ASM) (200 $\mu \mathrm{g}$ a.i./mL). The product induced local and systemic increases in chitinase and $\beta$ 1,3-glucanase activities in leaf tissues, starting from the first and second days after inducer application, respectively. The increases in enzymatic activity reached their maximum levels in treated plants compared to control seven days after application of ASM. Induction of local and systemic resistance against pathogen was detected one day after ASM treatment. Protection and increases in enzyme activities were detected up to 35 days after product application. Induction of local resistance against coffee leaf rust reached a highest level of $87 \%$ between 7 and 14 days. Highest levels of systemic 
protection ranging from 53\% to 68\% were observed in coffee plants between 2 and 21 days after inducer treatment. During the same time frame maximum increases in systemic enzymatic activity were also observed. Results suggest that the increases in these hydrolase activities were correlated with the local and systemic resistance induced by ASM in coffee plants against coffee leaf rust.

Genes related to SAR were identified in coffee plants by suppression subtractive hybridization (SSH), from mRNA isolated from susceptible plants cv. MN $72 \mathrm{~h}$ after treatment with ASM (200 $\mu \mathrm{g}$ a.i. $/ \mathrm{mL})$. The mechanisms of defense responses associated with SAR activated in MN were compared through the isolation of genes by SSH, with the race-specific resistance observed in the resistant coffee plant "Hibrido de Timor" (HT) $72 \mathrm{~h}$ after the inoculation with H. vastatrix. By SSH technique two subtracted cDNA libraries were constructed enriched for gene fragments induced in MN by ASM (MN-ASM) or activated in HT by pathogen infection (HT-Hv). The isolated genes were involved in different processes related to resistance against pathogens, such as: production of active oxygen species, hypersensitive response, programmed cell death, synthesis and transport of antimicrobial metabolites, signal perception and transduction, synthesis of pathogenesis-related proteins, lipid metabolism and selective degradation of proteins. It was identified in HT-Hv a higher number of defense-related genes (22 \%) than in MN-ASM (16\%). The incompatible interaction HT-Hv showed a higher number of genes implicated in the signal perception and transduction (44\%) than MN-ASM (30 \%). However, the number of genes encoding antimicrobial proteins was higher in the susceptible cultivar MN with induced resistance (22 \%) than in the resistant coffee plant HT inoculated with the incompatible pathogen (6\%). Genes encoding $\beta$ 1,3-glucanases were isolated from HT-Hv and MN-ASM and their complete sequences could be obtained by RACE procedure. Results suggest that distinct recognition events and defense pathways are involved in the expression of resistance in HT-Hv and MNASM. 


\section{INTRODUÇÃO}

A resistência de plantas contra doenças está associada a um conjunto de respostas de defesa ativadas pelo hospedeiro após o contato com agentes patogênicos. A ativação dessas respostas em plantas depende da eficiência do hospedeiro em reconhecer a presença de patógenos através de mecanismos de percepção e transdução de sinais, que envolvem alterações transitórias no fluxo de íons através da membrana plasmática e mudanças no estado de fosforilação de várias proteínas. Como conseqüência desse processo, ocorre a ativação de fatores de transcrição no núcleo da célula vegetal, com a expressão subseqüente de genes de defesa. A resistência é freqüentemente manifestada como uma resposta de hipersensibilidade, que resulta na morte celular localizada no sítio de penetração do patógeno. Outras respostas de resistência podem incluir alterações estruturais, o acúmulo de espécies de oxigênio reativas, a síntese de metabólitos secundários e a produção de uma ampla variedade de moléculas de defesa, tais como proteínas antimicrobianas (Schenk et al., 2000). A resistência pode também ser ativada em plantas suscetíveis, após a infecção localizada por fitopatógenos ou em resposta ao tratamento com agentes bióticos ou abióticos, sendo conhecida como resistência sistêmica adquirida ("systemic acquired resistance”, SAR) ou indução de resistência sistêmica (Hammerschmidt et al., 2001 e Sticher et al., 1997). A SAR tem sido demonstrada em várias interações hospedeiro-patógeno, conferindo uma proteção sistêmica de longa duração e amplo espectro, sendo efetiva contra doenças causadas por diferentes agentes bióticos, tais como, vírus, bactérias e fungos (Ryals et al., 1996). A indução da SAR resulta na restrição do crescimento de fitopatógenos e conseqüentemente, na supressão ou diminuição dos sintomas de doenças, devido à 
ativação dos mecanismos de resistência das plantas, associada à expressão coordenada de um conjunto de genes de defesa (Ryals et al., 1996).

A perspectiva promissora do controle de doenças através da ativação dos mecanismos de defesa inerentes das plantas, pela utilização de produtos bióticos ou abióticos, não tóxicos, tem estimulado vasta pesquisa, visando o esclarecimento dos aspectos bioquímicos e moleculares envolvidos na SAR. Tem sido demonstrado, em diferentes interações hospedeiro-patógeno estudadas, que a indução da SAR resulta na ativação de diferentes mecanismos bioquímicos de resistência. Entre esses, estão a alteração da parede celular vegetal pelo depósito de calose e lignina, o aumento na atividade de enzimas, tais como, fenilalanina amônia-liase, chalcona isomerase e peroxidases ou, ainda, o acúmulo de proteínas relacionadas à patogênese ("pathogenesisrelated proteins”, PR-proteínas) e fitoalexinas (Benhamou \& Bélanger, 1998; Bokshi et al., 2003; Iriti \& Faoro, 2003; Kohler et al., 2002; Latunde-Dada \& Lucas, 2001; Resende et al., 2002 e Suo \& Leung, 2002). Uma das estratégias que tem sido utilizada para elucidar as bases moleculares da resistência induzida envolve o estudo da expressão de genes em plantas, após o tratamento com patógenos, elicitores ou indutores químicos ativadores da SAR (Kohler et al., 2002; Schenk et al., 2000 e Xiong et al., 2001). Entre os indutores abióticos utilizados nesses estudos, podem ser mencionados além do ácido $\beta$ - aminobutírico, o ácido salicílico e os respectivos análogos funcionais, como o ácido 2,6-dicloroisonicotínico (INA) e o éster S-metil do ácido benzo-(1,2,3)-tiadiazole-7carbotióico (acibenzolar-S-metil, ASM) (Friedrich et al., 1996; Jakab et al., 2001; Mauch-Mani \& Métraux, 1998 e Métraux et al.,1991). O composto sintético ASM, derivado do benzotiodiazole, tem sido citado como um agente ativador dos mecanismos de defesa de plantas, conferindo proteção sistêmica contra diferentes patógenos em várias culturas, como, por exemplo, fumo, trigo, feijoeiro e cacaueiro (Friedrich et al., 1996; Görlach et al., 1996; Iriti \& Faoro, 2003 e Resende et al., 2002).

A ferrugem alaranjada do cafeeiro (Coffea arabica L.) tem como agente causal o fungo Hemileia vastatrix Berkeley et Broome pertencente à ordem Uredinales, família Pucciniaceae, sendo um parasita biotrófico exclusivo do gênero Coffea. Foi verificado que a SAR pode ser ativada em cafeeiro cultivar Mundo Novo, suscetível à ferrugem, 
após o tratamento com o composto acibenzolar-S-metil, conferindo proteção contra $H$. vastatrix (Guzzo et al., 2001). Estudos através de microscopia de fluorescência, sobre o desenvolvimento do patógeno em folhas previamente tratadas com o indutor de resistência e em folhas de plantas controle, não tratadas, indicaram que a germinação de esporos e a formação de apressórios por $H$. vastatrix não foram afetadas pelo tratamento com o ASM (Guzzo et al., 2001). De fato, agentes indutores da SAR, como o ASM, geralmente, não apresentam ação antimicrobiana direta sobre patógenos, mas induzem a expressão de genes de defesa das plantas, ativando, nas mesmas, a produção de compostos que impedem ou dificultam o estabelecimento e/ou desenvolvimento de patógenos (Friedrich et al., 1996; Kohler et al., 2002 e Ryals et al., 1996). Marchi et al. (2002) também verificaram que o ASM induziu proteção contra a ferrugem em cafeeiro cv. Catuaí Vermelho, quando aplicado às plantas três dias antes da inoculação com $H$. vastatrix. Por outro lado, a indução de resistência local e sistêmica em cafeeiro cv. Mundo Novo contra a ferrugem foi, também, obtida, através de tratamento prévio das plantas com uma formulação comercial de Bacillus thuringiensis, tendo sido correlacionada com a síntese das PR-proteínas, $\beta$-1,3-glucanases e quitinases (Guzzo \& Martins, 1996). As referidas enzimas catalisam, respectivamente, a hidrólise dos polímeros $\beta$-1,3-glucana e quitina, componentes principais das paredes celulares de muitos fungos, podendo apresentar atividade antimicrobiana. Essas hidrolases, detectadas em várias plantas após o contato com patógenos, metabólitos provenientes de microrganismos ou substâncias químicas que agem como indutores de resistência, têm sido associadas aos mecanismos de defesa contra fitopatógenos (Stangarlin \& Pascholati, 2000; Ryals et al., 1996 e Sticher et al., 1997).

A utilização adequada da indução de resistência visando o controle de doenças de plantas depende em grande parte do conhecimento sobre os genes e os mecanismos bioquímicos envolvidos na proteção mediada por indutores de resistência. Por outro lado, estudos sobre a expressão e identificação de genes ativados em plantas resistentes em resposta a microrganismos ou em plantas suscetíveis tratadas com indutores de resistência, permitem elucidar os mecanismos de defesa que restringem ou 
impossibilitam o desenvolvimento de fitopatógenos em combinações hospedeiropatógeno incompatíveis ou que apresentam resistência induzida.

Com o propósito de contribuir para o esclarecimento dos mecanismos bioquímicos e moleculares envolvidos na SAR ativada em plantas contra fitopatógenos, esse trabalho tem por objetivos:

1. Detectar, através de ensaios enzimáticos, proteínas relacionadas à patogênese (PR-proteínas), induzidas na SAR em cafeeiro suscetível cultivar Mundo Novo contra $H$. vastatrix, pela aplicação do indutor sintético acibenzolar-S-metil (ASM);

2. Isolar genes codificadores de proteínas relacionadas à SAR, ativada em cafeeiro cv. Mundo Novo após o tratamento com o ASM, através de hibridização subtrativa por supressão (HSS);

3. Comparar os mecanismos de respostas de defesa associados à SAR, ativada por ASM em cafeeiro suscetível cv. Mundo Novo, com a resistência raçacultivar específica na interação cafeeiro Híbrido de Timor - $H$. vastatrix, através do isolamento de genes por HSS. 


\section{REVISÃO DE LITERATURA}

\subsection{Considerações gerais sobre a interação Coffea arabica - Hemileia vastatrix}

A ferrugem alaranjada do cafeeiro, causada por Hemileia vastatrix, fungo biotrófico exclusivo do gênero Coffea, atinge todas as regiões cafeicultoras do Brasil e se não for devidamente controlada pode ocasionar decréscimos na produção que variam de $35 \%$ a 50\% (Zambolim et al., 2002). Os principais prejuízos ocasionados pela ferrugem consistem na redução da área foliar, pela formação de lesões e queda precoce das folhas e a seca dos ramos laterais, provocando gradualmente a deformação das plantas. A desfolha acarreta uma redução no florescimento e na frutificação, afetando a produtividade (Matiello et al., 2002). O controle químico da ferrugem no Brasil, tem se mostrado eficaz e vem sendo realizado através da utilização de fungicidas protetores cúpricos e/ou de fungicidas sistêmicos do grupo dos triazóis (Matiello et al., 2002 e Zambolim et al., 2002). Entretanto, pelo seu efeito na microbiota, eliminando inimigos naturais, pode levar ao agravamento de outras doenças e pragas do cafeeiro, além de possibilitar, por pressão de seleção, o surgimento de raças resistentes aos fungicidas aplicados (Matiello et al., 2002 e Zambolim et al., 2002). Outra abordagem viável para o controle da ferrugem do cafeeiro de menor impacto ambiental, consiste na utilização de cultivares portadores de resistência genética a $H$. vastatrix, visando a dispensa total ou parcial do controle químico, sendo que nos últimos anos vários cultivares têm sido colocados à disposição de produtores (Fazuoli et al., 2002; Pereira et al., 2002 e Sera et al., 2002). Existe ainda, a perspectiva de controle da doença pela ativação dos mecanismos de defesa inerentes das plantas, através da aplicação prévia de produtos 
bióticos ou abióticos, não tóxicos, que atuam como indutores de resistência (Martins, 1991 e Moraes, 1992).

O fungo $H$. vastatrix, pertencente à ordem Uredinales e família Pucciniaceae, se desenvolve na superfície abaxial foliar a partir da germinação dos urediniosporos na presença de água e temperatura favorável, em 6-8 h, podendo emitir de um a três tubos germinativos. $\mathrm{Na}$ extremidade do tubo germinativo ocorre a formação de apressório usualmente sobre um estômato, dando origem, em seguida, ao peg de penetração (hifa de penetração), o qual, após atravessar o ostíolo do estômato, diferencia-se em vesícula sub-estomática. O desenvolvimento subseqüente de hifa de infecção na câmara subestomática leva à colonização das células subsidiárias e do mesófilo, com a formação do micélio intercelular e em seguida, dos haustórios, estruturas responsáveis pela absorção de nutrientes pelo patógeno, dentro das células do hospedeiro (Martins, 1988 e Zambolim et al., 2002). Em cafeeiros suscetíveis, a colonização do mesófilo pela formação de numerosas hifas intercelulares e muitos haustórios, acaba dando origem aos soros uredospóricos, que saem em buquê através do estômato (Rijo \& Rodrigues, 1978). O fungo $H$. vastatrix, descrito inicialmente por Berkeley (1869) no Ceilão, encontra-se, atualmente, presente na maioria das regiões cafeeiras do mundo, com 40 raças fisiológicas já identificadas, sendo a raça II a mais amplamente distribuída. Além dessas já diferenciadas, cerca de seis novas raças estão sendo caracterizadas no Centro de Investigação das Ferrugens do Cafeeiro (CIFC) (Várzea et al., 2002).

As espécies do gênero Coffea de maior importância econômica são a Coffea arabica L. e Coffea canephora Pierre, conhecida como robusta, perfazendo cerca de $70 \%$ e $30 \%$, respectivamente, do café comercializado mundialmente (Fazuoli et al., 2002 e Matiello et al., 2002). O café robusta é resistente à maioria das raças do fungo, enquanto que os cultivares tradicionais de arábica utilizados comercialmente, são muito suscetíveis à ferrugem (Matiello et al., 2002 e Várzea et al., 2002). O cultivar Mundo Novo corresponde a uma recombinação resultante de um cruzamento natural entre os cultivares Sumatra e Bourbon Vermelho de C. arabica (Fazuoli et al., 2002). Sendo suscetível à maioria das raças de $H$. vastatrix, incluindo as mais comuns II e I, compõe, juntamente com os cultivares Catuaí Amarelo e Catuaí Vermelho, mais de $80 \%$ da 
cafeicultura nacional (Bettencourt, 1981; Carvalho \& Mônaco, 1972; Fazuoli, 1977 e Matiello et al., 2002). Por outro lado, o café Híbrido de Timor, derivado de um cruzamento interespecífico natural, provavelmente entre $C$. arabica cultivar Típica e $C$. canephora na Ilha de Timor, é resistente a todas as raças fisiológicas de $H$. vastatrix (Bettencourt, 1984; Rodrigues et al., 1975a e Várzea et al., 2002). O Híbrido de Timor é descendente de um cafeeiro encontrado em uma plantação do cultivar Típica de $C$. arabica, na Ilha de Timor em 1917, o qual não apresentava sintomas de ataque do patógeno $H$. vastatrix, em contraste com as outras plantas afetadas pela ferrugem do cafeeiro (Rodrigues et al., 1975a e Pereira et al., 2002). Devido a essa característica, a população de Híbrido de Timor constitui-se em um importante germoplasma, como fonte de resistência às doenças, para os programas de melhoramento genético do cafeeiro (Pereira et al., 2002). Segundo Várzea et al. (2002), muitas das variedades melhoradas atualmente cultivadas comercialmente, tiveram como fonte de resistência o Híbrido de Timor, selecionado no CIFC com as designações CIFC 832/1, CIFC 832/2 e CIFC 1343.

Martins (1988) e Martins \& Moraes (1996), através de estudos histológicos, observaram o desenvolvimento de $H$. vastatrix, predominantemente raça II, após a inoculação em C. arabica cultivar Mundo Novo com ou sem resistência induzida pela aplicação prévia de extrato de fermento e no híbrido Sarchimor, o qual apresenta resistência a todas as raças do patógeno. Os autores observaram que o fungo se desenvolveu de forma semelhante nas três interações estudadas, até a diferenciação de apressório em vesícula sub-estomática, que ocorreu entre 24 e 36 h após a inoculação. A expressão da incompatibilidade entre cafeeiro e ferrugem foi detectada em Sarchimor e em Mundo Novo com resistência induzida, entre 48 e 72 h após a inoculação do fungo, quando a inibição do desenvolvimento do patógeno pôde ser notada. Nesse estágio, foi detectada a formação dos primeiros haustórios, que apresentaram crescimento reduzido em Sarchimor. Após 96 h, a maioria dos haustórios na interação incompatível apresentou-se encapsulada em um espessamento, que se desenvolve a partir da parede celular do hospedeiro. Foi verificado, também, que a expressão da resistência induzida no cafeeiro suscetível pelo tratamento com extrato de levedura (Saccharomyces 
cerevisiae) 3 dias antes da inoculação do patógeno, ocorre $72 \mathrm{~h}$ após a inoculação de $H$. vastatrix. Nas plantas induzidas, $80 \%$ das colônias do fungo não puderam mais ser visualizadas $72 \mathrm{~h}$ após a inoculação. Foi aventada a hipótese de que o desaparecimento das colônias do fungo nas plantas induzidas, 6 dias após o tratamento com o indutor de resistência, poderia estar relacionado com a degradação das estruturas de infecção de $H$. vastatrix por enzimas sintetizadas pelo hospedeiro (Martins, 1988). Por outro lado, estudos imunocitoquímicos revelaram que as paredes das hifas intercelulares de $H$. vastatrix, bem como das células-mãe de haustório e dos haustórios, contêm $\beta-1,3$ glucanas e resíduos de $\mathrm{N}$-acetilglucosamina, monômeros formadores do polímero quitina (Silva et al., 1999 e Guerra-Guimarães et al., 2001). Esses polissacarídeos do patógeno poderiam ter sido degradados por enzimas hidrolíticas, como $\beta$-1,3-glucanases e quitinases, durante a resposta de resistência induzida em cafeeiro.

Estudos citológicos conduzidos em interações incompatíveis, utilizando-se diferentes genótipos de cafeeiro apresentando resistência completa a $H$. vastatrix, revelaram que uma das primeiras respostas de resistência consistiu na morte rápida das células do hospedeiro no sítio de infecção (Guerra-Guimarães et al., 2001 e Silva et al., 2002). Esta reação de hipersensibilidade observada nas células vegetais foi acompanhada pelo encapsulamento dos haustórios do patógeno através do depósito de calose e celulose. A reação de hipersensibilidade foi associada, também, com o acúmulo, nos espaços intercelulares, de material de composição heterogênea composto por pectinas, polissacarídeos e fenóis, com a lignificação e espessamento da parede celular e hipertrofia das células do hospedeiro (Martins \& Moraes, 1996 e Silva et al., 2002). Tem sido, também, associado à expressão de resistência do cafeeiro à $H$. vastatrix, o aumento de atividade de algumas enzimas, como, lipoxigenase (Rojas et al., 1993), peroxidase (Silva et al., 2000), fenilalanina amônia-liase (Silva et al., 2002) e as PR-proteínas, quitinases e/ou $\beta$-1,3-glucanases (Guerra-Guimarães et al., 2001; Guzzo \& Martins, 1996; Maxemiuc-Naccache et al., 1992). 


\subsection{Resistência sistêmica adquirida}

Foi observado inicialmente por Chester (1933) que plantas normalmente suscetíveis podiam adquirir resistência contra doenças após uma infecção primária causada por patógenos ou após o tratamento com formas atenuadas de agentes patogênicos. Posteriormente, Ross (1961) demonstrou que plantas de fumo após a infecção localizada com o vírus do mosaico do fumo (TMV) e a conseqüente formação de lesões necróticas nas folhas inferiores, adquiriam resistência sistêmica contra vários patógenos. Simultaneamente, Cruickshank \& Mandryk (1960), demonstraram que a infecção caulinar de plantas de fumo com o agente causal do míldio do fumo, Peronospora tabacina, levou a um aumento de resistência contra patógenos foliares. A resistência sistêmica pôde, também, ser induzida em plantas de pepino após o tratamento localizado com diferentes microrganismos patogênicos, como o vírus da necrose do fumo (TNV), Colletotrichum lagenarium e Pseudomonas syringae pv. lachrymans. As plantas foram protegidas por um período de 4 a 6 semanas contra pelo menos 12 doenças causadas por fungos, bactérias e vírus, como por exemplo, a antracnose e a sarna causadas, respectivamente, por C. lagenarium e Cladosporium cucumerinum, a mancha angular e a murcha bacteriana causadas por $P$. syringae pv. lachrymans e Erwinia tracheiphila e o mosaico do pepino e a necrose local causadas pelo vírus do mosaico do pepino (CMV) e por TNV, respectivamente (Kuć et al., 1975 e Dean \& Kuć, 1986).

Posteriormente, foi demonstrado que plantas suscetíveis previamente tratadas com raças avirulentas de um patógeno, patógenos incompatíveis, microrganismos não patogênicos, como por exemplo, leveduras, elicitores provenientes de patógenos, metabólitos de microrganismos ou agentes abióticos também apresentaram-se protegidas local e/ou sistemicamente, contra uma subseqüente inoculação com fitopatógenos (Kuć, 1995; Martins et al., 1985; Oostendorp et al., 2001; Pascholati, 1998 e Sticher et al., 1997). Foi observada uma restrição do crescimento de patógenos e, conseqüentemente, uma diminuição da extensão e severidade dos sintomas de doenças nas plantas previamente tratadas, quando comparadas com plantas não induzidas, infectadas pelos mesmos fitopatógenos (Heil \& Bostock, 2002; Ryals et al., 1996 e Sticher et al., 1997). 
O fenômeno, denominado de indução de resistência sistêmica ou resistência sistêmica adquirida (SAR), foi conceituado como sendo a ativação de um estado de resistência contra doenças, induzido sistemicamente em plantas pela infecção localizada por fitopatógenos ou em resposta ao tratamento com diferentes agentes bióticos ou abióticos (Hammerschmidt et al., 2001; Sticher et al., 1997 e Kuć, 2001). O fenômeno foi extensivamente caracterizado em pepino (Madamanchi \& Kuć, 1991), fumo (Kuć, 1982 e Vernooij et al., 1995) e Arabidopsis (Mauch-Mani \& Slusarenko, 1994 e Lawton et al., 1995) e demonstrado também, em outras culturas, como melão, melancia, algodão, soja, alfafa, feijão, trevo, cevada, trigo, arroz, batata, tomate, pêra, maçã, uva, cravo e café (Hammerschmidt et al., 2001; Kuć, 1995; Madamanchi \& Kuć, 1991; Ryals et al., 1996; Sticher et al., 1997 e Tuzun, 2001). O efeito protetor observado nas plantas se mostrou persistente e dependente das condições de luz, temperatura, das concentrações do indutor e do inóculo utilizadas e de um intervalo de tempo entre o tratamento inicial com o indutor de resistência e a inoculação subseqüente com o patógeno. A resistência induzida nas plantas não se mostrou específica, sendo efetiva contra vários tipos de patógenos (Madamanchi \& Kuć, 1991 e Kuć, 1995).

Diferentes compostos inorgânicos ou orgânicos não relacionados estruturalmente e diversas substâncias de origem biológica induziram resistência em plantas ao ataque por insetos herbívoros e contra doenças causadas por nematóides, bactérias, fungos e vírus (Bostock et al., 2001; Hammerschmidt et al., 2001; Heil \& Bostock, 2002; Kessmann et al., 1994; Kuć, 2001; Sticher et al., 1997 e Oostendorp et al., 2001). Essas substâncias foram denominadas de indutores, devido à sua capacidade de induzir resistência contra doenças nas plantas tratadas, sem apresentarem um efeito antimicrobiano direto sobre os agentes patogênicos. Entre os compostos inorgânicos, foi demonstrado que sais de fosfato induziram resistência sistêmica em plantas de pepino e milho contra os fungos fitopatogênicos C. lagenarium e Puccinia sorghi, respectivamente (Gottstein \& Kuć, 1989; Reuveni et al., 1994 e Orober et al., 2002). Entre os compostos orgânicos, os ácidos graxos araquidônico, linoleico, linolênico e oleico induziram resistência em batata contra Phytophthora infestans (Cohen et al., 1991 e Coquoz et al., 1995) e as quitosanas, em tomateiro contra Fusarium oxysporum f. sp. 
radicis-lycopersici (Benhamou \& Theriault, 1992). Além destes, foi demonstrada em diferentes interações hospedeiro-patógeno, a ação do ácido salicílico e dos respectivos análogos funcionais, INA e o acibenzolar-S-metil (ASM), como indutores da SAR (Friedrich et al., 1996; Mauch-Mani \& Métraux, 1998 e Métraux et al., 1991), como também, do aminoácido não protéico, o ácido $\beta$-aminobutírico (BABA) (Jakab et al., 2001). O tratamento de plantas de trigo e cevada com o ácido $\beta$-aminobutírico induziu resistência contra duas espécies de Heterodera medida pela redução de cerca de 90 \% na formação de cistos e acarretou, também, uma redução na produção da massa de ovos por uma espécie de nematóide do gênero Meloidogyne, que infecta especificamente monocotiledôneas. $\mathrm{O}$ desenvolvimento desse nematóide nas raízes das plantas tratadas com BABA foi também inibido (Oka \& Cohen, 2001). Oka et al. (1999) verificaram que o desenvolvimento do nematóide Meloidogyne javanica foi inibido em plantas de tomate previamente tratadas com o indutor BABA. Foi também demonstrada a ação desse composto como indutor de resistência sistêmica em muitas outras plantas contra diferentes patógenos, como por exemplo, em Arabidopsis thaliana contra os fungos Peronospora parasitica e Botrytis cinerea e contra a bactéria Pseudomonas syringae pv. tomato (Zimmerli et al., 2000), em videira contra o fungo Plasmopara viticola (Cohen et al., 1999), em couve-flor contra P. parasitica (Silué et al., 2002) e em fumo contra o TMV (Siegrist et al., 2000). Na maioria dos estudos efetuados, o composto BABA, não apresentou efeito tóxico direto sobre os fitopatógenos em ensaios in vitro (Jakab et al., 2001). Estudos efetuados em tomateiro e A. thaliana revelaram, também, que esse composto não sofre modificações dentro da planta, sendo absorvido e transportado através das plantas da base para o ápice, acumulando-se preferencialmente nas folhas mais jovens (Jakab et al., 2001).

O composto sintético acibenzolar-S-metil conferiu proteção em plantas de fumo (70 a 97\% para uma concentração de $1200 \mu \mathrm{M}$ ) contra o vírus TMV, os fungos Cercospora nicotianae, P. tabacina, Phytophthora parasitica e as bactérias Erwinia carotovora e P. syringae pv. tabaci (Friedrich et al., 1996) e em plantas de trigo (87 \% para uma concentração de $300 \mu \mathrm{M}$ ) contra o fungo Erysiphe graminis f.sp. tritici (Görlach et al., 1996). O ASM quando aplicado em A. thaliana $72 \mathrm{~h}$ antes da inoculação 
com patógenos, promoveu uma redução nos sintomas das doenças causadas pelo fungo $P$. parasitica, pela bactéria $P$. syringae pv. tomato e pelo vírus TCV ("turnip crinkle virus") (Lawton et al., 1996). Plântulas de tomate pré-tratadas com o ASM mostraram uma redução na severidade do cancro bacteriano causado por Clavibacter michiganensis subsp. michiganensis. A proteção observada foi correlacionada com uma redução de cerca de $68 \%$ no crescimento da bactéria durante a patogênese (Baysal et al., 2003). Entretanto, Tally et al. (1999) observaram que em plantas de tomate a resistência foi ativada pelo ASM contra P. infestans, mas nenhum efeito protetor significativo foi verificado em batata em relação ao mesmo patógeno. Os autores concluíram, baseados, também, em estudos efetuados com outras culturas, que o espectro de resistência ativado por ASM é específico e determinado para cada espécie vegetal. A SAR foi ativada, também, em outras culturas após a aplicação do ASM como, por exemplo, batata (Bokshi et al., 2003), pepino (Narusaka et al., 1999), roseira (Suo \& Leung, 2002), feijoeiro (Iriti \& Faoro, 2003), cacaueiro (Resende et al., 2002) e cafeeiro (Guzzo et al., 2001 e Marchi et al., 2002). O ASM, na maioria dos casos estudados, não apresenta atividade antimicrobiana direta sobre os patógenos, sendo um produto de baixa toxicidade e sistêmico, que é rapidamente absorvido e translocado através das plantas (Oostendorp et al., 2001 e Ruess et al., 1996). Experimentos realizados in vitro demonstraram que o ASM e seus metabólitos, na concentração de 1,4 mM, não afetam significativamente o desenvolvimento de 18 fungos (Friedrich et al., 1996). O produto, também, não inibiu o desenvolvimento do fungo $H$. vastatrix, nas fases de prépenetração (germinação e formação de apressórios), em cafeeiro (Guzzo et al., 2001). Não foi constatado efeito biocida in vitro do ASM sobre a germinação de urediniosporos de H. vastatrix (Marchi et al., 2002). Entretanto, foi verificado um efeito fungistático in vitro do ASM em Colletotrichum graminicola (Pascholati et al., 1998).

Por outro lado, foi verificado por alguns pesquisadores que o tratamento de plantas com ASM pode induzir resistência contra fitopatógenos, mas aumentar, simultaneamente, a suscetibilidade ao ataque por insetos herbívoros. Em experimentos realizados em tomateiro, a aplicação foliar prévia de ácido jasmônico, mas não a de ASM ou ácido salicílico, protegeu as plantas contra as larvas da lagarta Spodoptera 
exigua e da broca Helicoverpa zea, refletida pelas taxas de crescimento reduzidas e menor sobrevivência das larvas nas folhas induzidas, tratadas com esse regulador vegetal (Thaler et al., 1999; Thaler et al., 2001 e Bostock et al., 2001). As plantas induzidas com ácido jasmônico apresentaram uma redução de 60 \% nos danos foliares provocados pelo ataque dos insetos herbívoros, em relação às plantas controle (Thaler et al., 2001). O tratamento de folhas de tomateiro com o ASM (1,2 mM) induziu resistência contra $P$. syringae pv. tomato, manifestada pela redução do número e tamanho de lesões nas folhas protegidas sistemicamente. Entretanto, as larvas de insetos da família Noctuidae se desenvolveram melhor nas plantas tratadas com ASM expressando a SAR, do que no controle, não tratado (Bostock et al., 2001). Plantas de tomate tratadas com ASM comprometeram a resistência do hospedeiro às larvas de $S$. exigua, em experimentos realizados em condições de campo (Thaler et al., 1999). Os autores concluíram que a SAR induzida por alguns tratamentos químicos pode trazer um risco potencial, aumentando a vulnerabilidade das plantas a determinados insetos herbívoros (Bostock et al., 2001).

Entretanto, experimentos conduzidos por outros pesquisadores indicam que a ativação de mecanismos de defesa em plantas através da aplicação exógena de indutores abióticos de resistência pode resultar em uma redução simultânea dos danos causados por vários patógenos e insetos herbívoros. Inbar et al. (1998) aplicaram os indutores abióticos de respostas de defesa, ASM, probenazole, quitosana, ácido salicílico, em tomateiro em condições de campo e avaliaram a habilidade desses compostos para promover, simultaneamente, resistência contra diferentes patógenos e insetos herbívoros. Somente o ASM induziu resistência simultânea contra diferentes fitopatógenos e contra a larva minadora Liriomyza spp. O composto ASM reduziu significativamente a incidência da mancha bacteriana, da pinta preta e da mancha de Cladosporium causadas, respectivamente, por Xanthomonas campestris pv. vesicatoria, Alternaria solani e Cladosporium fuvum e a densidade das larvas de Liriomyza spp. Os efeitos sobre as densidades das larvas de Liriomyza spp foram mais pronunciados durantes os primeiros estádios de desenvolvimento da planta. Alguns dos indutores avaliados, embora tenham controlado determinados fitopatógenos, não apresentaram efeito significativo sobre a 
população de insetos. O efeito do ASM sobre a larva minadora foi confirmado por ensaios em laboratório, tendo sido constatado que as larvas apresentaram melhor desempenho nas plantas não tratadas com esse indutor de resistência. Pascual et al. (2003) observaram, também, que a aplicação foliar de ASM (0,2 g/L) em plantas de tomate induziu resistência contra a mosca branca Bemisia tabaci, vetor do geminivírus, "tomato leaf curl virus".

Existem vários relatos na literatura de diversas substâncias de origem biológica que agem como indutores de resistência (Kuć, 2001), como por exemplo, frações de parede celular de plantas, de fungos (Doke et al., 1987) e de bactérias, como lipopolissacarídeos de rizobactérias promotoras de crescimento de plantas (Pieterse et al., 2001b e Van Loon et al., 1998); fluído intercelular de plantas; extratos vegetais (Fought \& Kuć, 1996) e de microrganismos não patogênicos, como S. cerevisiae (Pascholati, 1998) e substâncias provenientes de fitopatógenos, como Phytophthora spp., Pyricularia oryzae e Erwinia amylovora (Keller et al., 1996; Schaffrath et al., 1995; Wei et al., 1992 e Yu, 1995). Foi verificado que as elicitinas, uma família de pequenas proteínas altamente conservadas, secretadas por espécies de fungos fitopatogênicos do gênero Phytophthora (Ricci et al., 1989) ou Pythium (Panabières et al., 1997), são capazes de ativar respostas de defesa em plantas e a SAR. Plantas de fumo previamente tratadas com elicitinas, especialmente a criptogeína, purificada de filtrado de cultura de Phytophthora cryptogea, adquirem resistência à uma infecção subseqüente com o patógeno Phytophthora parasitica var. nicotianae e a outros agentes patogênicos (Etienne et al., 2000 e Ricci et al., 1989). Foi constatado, também, que a proteína Harpina rica em glicina, produzida pela bactéria patogênica E. amylovora, induz resistência sistêmica em plantas contra várias doenças causadas por fungos, bactérias e vírus e também contra alguns insetos herbívoros (Capdeville et al., 2003, Peng et al., 2003 e Wei et al., 1992).

Tem sido demonstrado, em diferentes interações hospedeiro-patógeno, que a indução da SAR resulta na proteção de plantas contra uma ampla variedade de fitopatógenos e de insetos herbívoros, devido à ativação de diversos mecanismos de resistência. Entre os mecanismos ativados têm sido observadas a resposta de 
hipersensibilidade, resultando na morte localizada de células do hospedeiro no sítio de infecção do patógeno (Orober et al., 2002 e Silué et al., 2002) e alterações estruturais, levando ao fortalecimento da parede celular vegetal pelo depósito de calose e de lignina (Benhamou \& Bélanger, 1998 e He et al., 2002) ou pela formação de papila junto à parede celular no sítio de penetração do patógeno (Besser et al., 2000). Foi detectado o acúmulo de peróxido de hidrogênio (Iriti \& Faoro, 2003), de fitoalexinas (Hwang et al., 1997 e Latunde-Dada \& Lucas, 2001) e de PR-proteínas (Bokshi et al., 2003 e Ziadi et al., 2001) e também, um aumento na atividade de várias enzimas, tais como lipoxigenase (Buzi et al., 2004), fenilalanina amônia-liase (FAL) (Stadnik \& Buchenauer, 2000), chalcona isomerase (Latunde-Dada \& Lucas, 2001), peroxidases (Baysal et al., 2003) e polifenol oxidases (Thaler et al., 2001).

A ativação rápida de reações de defesa em associação com a morte celular do hospedeiro é freqüentemente denominada de resposta de hipersensibilidade. A morte localizada de algumas células vegetais no sítio de penetração de patógenos pode se constituir em um processo eficaz para a contenção de patógenos biotróficos, que necessitam de células vivas para obtenção de nutrientes durante seu desenvolvimento. No caso de organismos necrotróficos a morte celular pode ser nociva, pois o colapso da célula vegetal acarreta a liberação de compostos pré-formados, estocados no vacúolo, tóxicos aos microrganismos, que se acumulam nos sítios de infecção impossibilitando o estabelecimento desses patógenos (Hammond-Kosack \& Jones, 1996). A resistência sistêmica induzida em pepino contra a antracnose causada por C. lagenarium pela aplicação foliar de sais de fosfato $\left(\mathrm{K}_{2} \mathrm{HPO}_{4}\right)$ foi correlacionada com a morte celular localizada (Orober et al., 2002). A morte de células do hospedeiro observada em folhas de pepino tratadas com o sal de fosfato foi precedida por uma rápida produção de espécies de oxigênio reativas, como o ânion superóxido e o peróxido de hidrogênio. A resposta de hipersensibilidade resultou, subseqüentemente, na produção de manchas necróticas visíveis macroscopicamente, tendo sido observado, também, um aumento local e sistêmico de ácido salicílico livre ou conjugado. Silué et al. (2002), também, observaram que a resistência sistêmica induzida pelo composto BABA em plântulas de couve-flor contra o agente causal do míldio, P. parasitica, foi acompanhada por uma 
reação de hipersensibilidade. As manchas necróticas se tornaram evidentes antes da inoculação subseqüente com o patógeno. Esse mecanismo de defesa foi também observado em outras plantas apresentando resistência induzida contra diferentes patógenos, através da aplicação de indutores abióticos ou bióticos. Por exemplo, em cevada contra a infecção causada por Blumeria graminis f.sp. hordei após a aplicação de ácido salicílico, INA ou ASM (Besser et al., 2000); em videira contra P. viticola pela aplicação de BABA (Cohen et al., 1999); em aspargos contra Fusarium oxysporum f.sp. asparagi após o tratamento das raízes das plantas com isolados não patogênicos de $F$. oxysporum (He et al., 2002) e em A. thaliana contra P. parasitica pela aplicação de BABA (Zimmerli et al., 2000).

De fato, a SAR, normalmente, é observada em plantas após a formação localizada de lesões necróticas nos tecidos vegetais, provocadas pela presença de patógenos ou relacionadas à resposta de hipersensibilidade (Ryals et al., 1996 e Sticher et al., 1997). Entretanto, a resistência induzida nem sempre está associada com a resposta de hipersensibilidade. Iriti \& Faoro (2003), verificaram através de estudos histoquímicos e citoquímicos, que a aplicação de ASM em cultivares suscetíveis de feijoeiro induziu resistência sistêmica contra a ferrugem causada por Uromyces appendiculatus e acúmulo de peróxido de hidrogênio $\left(\mathrm{H}_{2} \mathrm{O}_{2}\right)$ nos tecidos vegetais. A produção de espécies reativas de oxigênio, uma das primeiras respostas de defesa ativadas em plantas, pode acarretar a resposta de hipersensibilidade. Entretanto, não foi observada morte celular nas plantas induzidas à resistência pela aplicação de ASM. Os autores inferiram que a resistência induzida contra a ferrugem do feijoeiro, por esse indutor abiótico, está particularmente associada com o aumento de atividade de peroxidases aniônicas, promovido pelo acúmulo de $\mathrm{H}_{2} \mathrm{O}_{2}$. A produção dessas enzimas resultou no fortalecimento da parede celular do hospedeiro, constituindo-se em uma barreira principal à infecção do patógeno durante a fase de penetração para formar haustórios e na emergência de $U$. appendiculatus a partir da epiderme para $o$ desenvolvimento de pústulas.

Outras alterações estruturais como o depósito de calose e de lignina ou a formação de papilas no sítio de infecção, resultam, também, no fortalecimento da parede 
celular do hospedeiro dificultando a entrada de patógenos ou a troca de nutrientes entre estes e a célula vegetal. Enquanto que a calose e a lignina, que são polímeros, constituídos, respectivamente, de $\beta$-1,3-glucana e de álcoois cinâmicos (compostos fenilpropanóides), se depositam normalmente na parede celular do hospedeiro, a papila, que é uma estrutura contendo especialmente calose e compostos fenólicos, se forma junto à parede celular vegetal no sítio de penetração do patógeno. A aplicação foliar de ASM em tomateiro aumentou a resistência das plantas contra o patógeno de solo $F$. oxysporum f.sp. radicis-lycopersici. O ingresso do fungo foi aparentemente detido pela formação de aposições na parede celular vegetal ricas em calose nos sítios de penetração do patógeno, tendo sido observado, também, o depósito de compostos fenólicos junto às paredes das células do fungo (Benhamou \& Bélanger, 1998). Além da resposta de hipersensibilidade observada em videira, previamente tratada com o indutor BABA, foi detectado um acúmulo de lignina nas paredes de células do hospedeiro sob o sítio de penetração de P. viticola (Cohen et al., 1999). A formação de papilas no sítio de infecção de B. graminis f.sp. hordei junto às paredes de células de cevada pré-tratadas com ácido salicílico, INA ou ASM, constituiu-se em um mecanismo efetivo de defesa das plantas, dificultando a penetração do patógeno (Besser et al., 2000). Foi observado, também, por Zimmerli et al. (2000), que o composto BABA protegeu Arabidopsis contra P. parasitica através da ativação de mecanismos de defesa, tais como, depósito de calose, resposta de hipersensibilidade e a formação de necrose nas células do hospedeiro.

Essas alterações estruturais podem também reter compostos antimicrobianos no sítio de infecção como fenóis e fitoalexinas, substâncias de baixo peso molecular lipofílicas, que se acumulam rapidamente no sítio de infecção. Plântulas de um cultivar suscetível de Vigna unguiculata, obtidas a partir de sementes tratadas com ASM, mostraram-se protegidas contra a antracnose causada por Colletotrichum destructivum (Latunde-Dada \& Lucas, 2001). Após a penetração, o patógeno permaneceu confinado nas primeiras células da epiderme do hospedeiro, que apresentaram uma reação de hipersensibilidade acompanhada de necrose e do aumento rápido de atividade de FAL e chalcona isomerase, duas enzimas chave nas vias biossintéticas de fenilpropanóides e 
flavonóides, respectivamente. Subseqüentemente, foi observado nos tecidos vegetais, o acúmulo rápido das fitoalexinas de leguminosas, kievitona e faseolidina. Nas plantas suscetíveis não tratadas com ASM e inoculadas com o patógeno, o aumento de atividade das enzimas e a síntese das fitoalexinas ocorreram de forma tardia e em concentrações bem menores, quando comparados com as plantas induzidas à resistência. Os autores inferiram que o acúmulo desses compostos nas plantas pré-tratadas com o ASM, após a inoculação, impediu a colonização dos tecidos do hospedeiro por C. destructivum, confinando o patógeno no sítio de penetração.

O aumento de atividade da enzima FAL, que catalisa a formação do ácido cinâmico a partir de fenilalanina, iniciando a via biossintética dos compostos fenilpropanóides, foi detectado, também, em outras plantas induzidas à resistência, como por exemplo, Arabidopsis (Kohler et al., 2002), trigo (Stadnik \& Buchenauer, 2000) e aspargo (He et al., 2002). Stadnik \& Buchenauer (2000) verificaram, que o composto ASM induziu resistência sistêmica em um cultivar suscetível de trigo contra Blumeria graminis f.sp. tritici, acompanhada pela formação de papila no sítio de penetração do patógeno e do aumento de atividade de FAL e peroxidase. Foram observados, também, o acúmulo de compostos fenólicos ligados à parede celular vegetal no sítio de infecção e uma diminuição na eficiência de penetração do fungo. A inibição da FAL reduziu o acúmulo localizado dos compostos fenólicos e suprimiu a resistência induzida pelo ASM. Os autores concluíram que os compostos fenilpropanóides, possivelmente ácidos fenólicos esterificados à parede celular vegetal, são mais rapidamente sintetizados em resposta à infecção pelo oídio, em plantas pré-tratadas com o ASM. Portanto, um rápido acúmulo desses compostos no sítio de penetração de B. graminis f.sp. tritici pode estar envolvido na resistência induzida por ASM. Os resultados obtidos por esses autores evidenciam que a enzima FAL pode ser essencial para a ativação da SAR em determinadas interações planta-patógeno.

As peroxidases podem estar envolvidas na síntese de lignina e na interligação oxidativa entre as cadeias de glicoproteínas ricas em hidroxiprolina presentes na parede celular vegetal (Hammond-Kosack \& Jones, 1996). O aumento dessas enzimas foi detectado em diversas plantas induzidas à resistência como, tomate (Baysal et al., 2003), 
melão (Buzi et al., 2004), aspargo (He et al., 2002), feijão (Iriti \& Faoro, 2003), cacau (Resende et al., 2002) e trigo (Stadnik \& Buchenauer, 2000). O aumento de atividade de outras enzimas envolvidas em respostas de defesa, como polifenol oxidases e lipoxigenases, tem sido observado em plantas suscetíveis após a indução de resistência com indutores bióticos ou abióticos. As polifenol oxidases catalisam a oxidação de compostos fenólicos, enquanto que as lipoxigenases estão envolvidas na peroxidação de lipídeos da membrana celular vegetal e na síntese do regulador vegetal, ácido jasmônico. Um aumento de atividade de polifenol oxidase e/ou peroxidase foi detectado em diferentes cultivares de plantas de cacau protegidas contra Crinipellis perniciosa e Verticillium dahliae por ASM (Resende et al., 2002). Thaler et al. (2001) verificaram que a aplicação foliar de ácido jasmônico em tomateiro induziu resistência contra diferentes insetos herbívoros no campo e aumento de atividade de inibidores de proteinase e polifenol oxidase. Experimentos conduzidos no campo durante três anos indicaram que a indução dessas proteínas de defesa está associada com a diminuição na abundância de herbívoros, que preferiram plantas controle às induzidas. Buzi et al. (2004) verificaram que a infecção causada pelo patógeno de solo Didymella bryoniae foi completamente suprimida em plântulas de melão obtidas a partir de sementes tratadas com metil jasmonato, tendo sido observado, também, um aumento rápido de lipoxigenase e das PR-proteínas, quitinase e peroxidase.

As PR-proteínas constituem-se em proteínas de plantas que se acumulam rapidamente nos tecidos vegetais após o contacto com patógenos ou ataque por insetos herbívoros ou, também, em resposta ao tratamento com determinados compostos químicos ou a outros tipos de estresse (Van Loon et al., 1994). Estão localizadas no espaço intercelular, no vacúolo e/ou parede da célula vegetal, tendo sido encontradas em várias espécies de plantas pertencentes a diferentes famílias. A maioria possui um peptídeo-sinal na região N-terminal, responsável por sua translocação através da membrana do retículo endoplasmático para o vacúolo ou para o espaço intercelular (Bol et al., 1990). Apresentam algumas características gerais como baixo peso molecular, estabilidade em meio ácido e resistência a proteases. Atualmente são classificadas em 17 famílias distintas, baseando-se na similaridade das seqüências de aminoácidos, relação 
sorológica e/ou atividade enzimática ou biológica. Muitas apresentam atividade antimicrobiana comprovada ou podem ativar outras respostas de defesa em plantas (Kombrink \& Hahlbrock, 1986 e Roulin \& Buchala, 1995). As PR-proteínas têm sido particularmente associadas com a SAR (Pieterse et al., 2001a e Ryals et al., 1996).

As PR-proteínas acumulam-se nos tecidos vegetais no local de aplicação de indutores bióticos ou abióticos da SAR e sistemicamente, em partes da planta distantes do ponto inicial de aplicação, estando associadas com a expressão e manutenção da resistência sistêmica induzida (Conrath et al., 2002; Pieterse et al., 2001a e Ryals et al., 1996). PR-proteínas associadas à SAR foram detectadas em muitas plantas, como por exemplo, em fumo (Pan et al., 1991), tomate (Benhamou et al., 1994), batata (Schröder et al., 1992), feijão (Dann et al., 1996), pepino (Strobel et al., 1996), melão (Roby et al., 1988 e Buzi et al., 2004), pimenta (Hwang et al., 1997), cafeeiro (Guzzo \& Martins, 1996) e videira (Busam et al., 1997).

As PR-proteínas, $\beta$-1,3-glucanases e quitinases, têm sido detectadas em várias plantas após a ativação da SAR e são capazes de degradar, respectivamente, glucanas e quitinas, presentes nas paredes celulares de muitos fungos. As quitinases da classe III, pertencentes à família de PR-proteínas, PR-8, possuem atividade enzimática adicional similar à lisozima, catalisando a hidrólise do polímero peptídeoglicano, componente estrutural das paredes celulares de bactérias (Fritig et al., 1998 e Van Loon et al., 1994). Em plantas de café, pimenta, pepino e fumo, a resistência induzida contra $H$. vastatrix, Phytophthora capsici, C. lagenarium e P. tabacina, respectivamente, foi correlacionada com o aumento da atividade de $\beta$-1,3-glucanases e/ou quitinases (Guzzo \& Martins, 1996; Hwang et al., 1997; Métraux \& Boller, 1986 e Pan et al., 1991). Foram utilizados nestas interações, indutores de resistência bióticos ou abióticos. Em cafeeiro, a resistência foi induzida pela aplicação de uma formulação comercial da bactéria $B$. thuringiensis, enquanto que em plantas de fumo foram utilizadas inoculações localizadas com P. tabacina ou com TMV. Para induzir resistência em plantas de pepino, apenas a folha primária foi inoculada com vírus (TNV), bactéria (P. lachrymans) ou com fungo (Pseudoperonospora cubensis) ou, ainda, tratada com etileno. Plantas de pimenta foram protegidas contra $P$. capsici através da pulverização com o indutor abiótico BABA 
(Hwang et al., 1997). O BABA desencadeou um aumento drástico de ácido salicílico e induziu a síntese e acúmulo de $\beta$-1,3-glucanases e quitinases nos tecidos caulinares das plantas. A resistência a $P$. capsici induzida em plantas de pimenta pelo tratamento com BABA foi positivamente correlacionada com o acúmulo de ácido salicílico e de certas isoformas de $\beta-1,3$-glucanases e quitinases. Os autores sugeriram que o ácido salicílico pode agir como um sinal endógeno responsável por ativar determinados componentes de resistência ao patógeno e a indução de PR-proteínas (Hwang et al., 1997).

Foi verificado, também, que a proteína harpina, isolada de P. syringae 61, induziu a SAR em pepino contra diversos patógenos, incluindo o fungo C. lagenarium, o vírus da necrose do fumo e a bactéria $P$. syringae pv. lachrymans. A expressão da SAR foi acompanhada por aumentos nas atividades das PR-proteínas, peroxidase, $\beta-1,3-$ glucanase e quitinase (Strobel et al., 1996). O aumento de resistência induzido em plântulas de tomate contra a bactéria C. michiganensis através da aplicação do indutor ASM foi, também, associado com aumentos significativos nas atividades de peroxidase e quitinase (Baysal et al., 2003). Da mesma forma, o nível aumentado de resistência contra os patógenos de solo $D$. bryoniae e Sclerotinia sclerotiorum observado em plântulas de melão, obtidas de sementes tratadas com ASM ou metil jasmonato, foi associado com um aumento rápido na atividade das PR-proteínas quitinase e peroxidase (Buzi et al., 2004).

O acúmulo de PR-proteínas foi também observado na resistência induzida contra insetos herbívoros. Inbar et al. (1998) verificaram que a indução de resistência conferida por ASM em plantas de tomate em condições de campo contra diferentes fitopatógenos e também contra a larva minadora Liriomyza spp. e a mosca-branca Bemisia argentifolii foi acompanhada pelo acúmulo de PR-proteínas. O ASM induziu nas plantas altos níveis das PR-proteínas, peroxidases, lisozimas, quitinases e $\beta-1,3-$ glucanase.

Foi verificado que a indução ou aumento da expressão de um determinado grupo de genes, denominados genes-SAR ou genes marcadores da SAR, está estreitamente correlacionada com o início da SAR ativada em diferentes plantas, como A. thaliana, fumo, trigo, milho e centeio (Ryals et al., 1996). O início da expressão 
desses genes está relacionado com a expressão da resistência induzida, sendo que muitos codificam PR-proteínas (Pieterse et al., 2001a e Ryals et al., 1996). Em fumo, por exemplo, o conjunto de marcadores da SAR, consiste de pelo menos seis famílias de PRproteínas, compreendendo três proteínas ácidas e uma básica da família PR-1, as $\beta-1,3-$ glucanases ácidas da família PR-2, as quitinases ácidas da família PR-3, quitinases da família PR-4, as proteínas tipo taumatinas ácidas da família PR-5 e as isoformas ácidas e básicas das quitinases classe III da família PR-8 (Friedrich et al., 1996; Heitz et al., 1994 e Ward et al., 1991). Em A thaliana os genes marcadores da SAR codificam as proteínas PR-1, PR-2 e PR-5 (Uknes et al., 1992 e Van Wees et al., 2000).

Em experimentos realizados com plantas transgênicas ou plantas mutantes de Nicotiana tabacum ou A. thaliana foi observado que a SAR é ativada por uma via de transdução de sinal dependente de ácido salicílico e da proteína reguladora NPR1 (Pieterse et al., 2001a). Plantas deficientes no acúmulo de ácido salicílico ou NPR1 são incapazes de desencadear a SAR e de ativar a síntese das PR-proteínas associadas a essa resposta (Delaney et al., 1995 e Nawrath \& Métraux, 1999). Zhang et al. (1999) demonstraram que sob indução da SAR, a NPR1 ativa em plantas a expressão do gene $P R$ - 1 , interagindo fisicamente com uma subclasse de fatores de transcrição constituídos por proteínas básicas com domínio de zíper de leucina (bZIP). Essas proteínas ligam-se nas seqüências do promotor requerido para a expressão do gene $P R-1$, sugerindo uma ligação direta entre atividade de NPR1 e regulação da expressão de genes codificadores de PR-proteínas (Zhang et al., 1999 e Zhou et al., 2000). Essas observações indicam que as PR-proteínas possuem um papel relevante na resistência sistêmica adquirida em plantas, contribuindo, possivelmente, para o efeito protetor observado contra diferentes patógenos. Por outro lado, estudos conduzidos, também, em A. thaliana revelaram que determinadas estirpes da rizobactéria Pseudomonas fluorescens induzem resistência sistêmica nesta planta contra diferentes patógenos, ativando uma via sinalizadora independente de ácido salićlico, mas dependente de ácido jasmônico e etileno. Entretanto, a resistência induzida mediada por P. fluorescens é controlada, também, pelo fator regulador NPR1, embora seja independente da expressão de genes codificadores de PR-proteínas (Pieterse et al., 2001b). 
Foi demonstrado, em algumas interações hospedeiro-patógeno, que o tratamento das plantas com determinados indutores de resistência leva à ativação direta de um conjunto de respostas de defesa. Entretanto, alguns mecanismos de resistência são ativados apenas após a inoculação subseqüente das plantas com agentes patogênicos. Nesse caso, o tratamento prévio com indutores de resistência predispõe as plantas suscetíveis para ativar respostas de defesa mais rapidamente e intensamente do que plantas não induzidas, quando em contacto com agentes patogênicos. Os indutores de resistência possuiriam, dessa forma, um papel duplo na ativação de respostas de defesa. Este mecanismo, denominado de preparo ou sensibilização ("priming”), foi demonstrado em Arabidopsis (Conrath et al., 2002 e Kohler et al., 2002). Foi observado nas plantas tratadas com o indutor sintético ASM, uma acentuada expressão de gene codificador da PR-proteína, PR-1. Embora, o ASM tenha sido inativo para induzir imediatamente a expressão de gene codificador de fenilalanina amônia-liase e o depósito de calose em Arabidopsis, estas respostas de defesa foram ativadas nas plantas pré-tratadas, após a inoculação com $P$. syringae pv. tomato, ferimento ou infiltração das folhas com água. $\mathrm{O}$ tratamento com esse indutor de resistência aumentou a habilidade das plantas para ativar estas respostas de defesa (Kohler et al., 2002). Hwang et al. (1997), também, observaram que o tratamento de plantas de pimenta com o composto BABA induziu, nos tecidos caulinares, um acúmulo de $\beta$-1,3-glucanases e quitinases, mas não da fitoalexina capsidiol, um sesquiterpeno antimicrobiano. Entretanto, o tratamento prévio com o indutor de resistência BABA, levou a um acentuado acúmulo de capsidiol, após a inoculação das plantas com $P$. capsici. De forma similar, a resistência induzida em plântulas de couve-flor contra P. parasitica, após aplicação de BABA, foi acompanhada de uma resposta de hipersensibilidade, mas não do acúmulo de PR-proteínas. Somente as plantas tratadas com BABA e posteriormente inoculadas com o patógeno acumularam $\beta$-1,3-glucanases (Silué et al., 2002).

O fenômeno da SAR implica, também, na produção de um sinal liberado a partir do sítio inicial de penetração do patógeno ou do local de aplicação do indutor e sua posterior translocação para outras partes da planta, ativando nesses tecidos reações de defesa e impedindo, à distância, uma posterior infecção do patógeno (Madamanchi \& 
Kuć, 1991). Foi constatado que a aplicação exógena de ácido salicílico induziu a SAR e a expressão coordenada de genes SAR em plantas (Vernooij et al., 1994 e Ward et al., 1991). Além desse aspecto, foi observado que o ácido salicílico é produzido localmente em plantas no sítio de infecção de patógenos ou após o tratamento com indutores de resistência, sendo encontrado, também, no floema e em folhas não tratadas (Sticher et al., 1997). Estudos desenvolvidos em plantas de fumo e Arabidopsis evidenciaram que o ácido salicílico é um sinal crítico para a ativação de respostas de resistência locais e sistêmicas e está envolvido na via de transdução do sinal sistêmico na SAR (Gaffney et al., 1993; Lawton et al., 1995 e Métraux, 2001). Plantas transgênicas que expressam o gene NahG, o qual codifica a enzima salicilato hidroxilase que catalisa a conversão de ácido salicílico em catecol, rapidamente degradam o ácido salicílico, não possuem habilidade em desenvolver um estado imune e demonstram um aumento de suscetibilidade a fitopatógenos (Gaffney et al., 1993 e Lawton et al., 1995). Outros estudos utilizando vários mutantes de Arabidopsis, também, corroboram a importância do ácido salicílico para a SAR (Glazebrook, 1999). Entretanto, pesquisas efetuadas com diferentes combinações de enxertia em plantas de fumo transgênicas que expressam o gene $n a h \mathrm{G}$ e plantas não transformadas, demonstraram que o ácido salicílico não é o sinal translocado que desencadeia a SAR em outras partes da planta, embora seja requerido para expressão da resistência induzida (Métraux, 2001 e Ryals et al., 1996). Trabalhos recentes indicam moléculas lipídicas como mensageiras sistêmicas da SAR. Maldonado et al. (2002) conduziram estudos utilizando uma planta mutante de A. thaliana defeituosa em induzir resistência (dir 1-1). Essa planta, embora apresente capacidade de exibir resistência local contra $P$. syringae, não possui a habilidade de expressar genes codificadores de PR-proteínas em folhas distantes, não inoculadas. Além da expressão sistêmica desses genes ter sido abolida, as plantas mutantes são falhas em desenvolver a SAR contra isolados virulentos de $P$. syringae pv. tomato ou $P$. parasitica. Experimentos realizados com exudatos de pecíolo indicaram que as plantas dir 1-1 são defeituosas na produção ou transmissão, a partir da folha inoculada, de um sinal móvel essencial para a expressão da resistência sistêmica. DIR1 parece desempenhar, portanto, um papel na produção ou translocação do sinal da SAR que se 
move a partir das folhas inoculadas para outras partes da planta. Foi verificado que o gene DIR1 codifica uma proteína de transferência de lipídeos, localizada possivelmente no apoplasto da célula vegetal. Os autores propuseram que a proteína DIR1 interage com uma molécula lipídica para promover a sinalização à longa distância, responsável pela expressão da resistência sistêmica. Por outro lado, Kumar \& Klessig (2003) isolaram uma proteína de fumo denominada SABP2, que apresenta atividade de lipase e se liga especificamente ao ácido salicílico. Em decorrência dessa ligação, a atividade enzimática de SABP2 é estimulada, possibilitando a produção de uma molécula sinalizadora de natureza lipídica. O silenciamento da expressão do gene $S A B P 2$ suprimiu a resistência local e sistêmica em plantas de fumo contra a infecção por patógenos e a expressão do gene codificador da PR-proteína, PR-1. Os autores especularam que a atividade de lipase de SABP2, estimulada após a ligação dessa proteína com o ácido salicílico, pode gerar uma molécula lipídica que seria translocada pela proteína de transferência de lipídeos codificada pelo gene DIR1 para partes não inoculadas da planta, transmitindo o sinal para expressão da resistência sistêmica nesses tecidos vegetais.

\subsection{Ativação da expressão de genes de resistência}

A identificação de genes de hospedeiros envolvidos em respostas de defesa é importante para a elucidação dos mecanismos de resistência em plantas contra fitopatógenos. A seleção diferencial de bibliotecas de cDNA, produzidas a partir de mRNAs isolados de plantas inoculadas, tratadas com elicitores ou indutores de resistência e de cultura de células, tem sido utilizada para identificar genes relacionados à defesa em muitas interações hospedeiro-patógeno. Um clone de cDNA do gene de sorgo codificador de uma PR-proteína da família PR-10 que apresenta potente função de ribonuclease, foi isolado de uma biblioteca de cDNA por seleção diferencial. A biblioteca de cDNA foi preparada a partir de mRNAs isolados de mesocótilos de um cultivar resistente de sorgo, inoculados com Colletotrichum sublineolum, agente causal da antracnose do sorgo (Lo et al., 1999). Um estudo do padrão da expressão de genes 
codificadores da PR-10 e de chalcona sintase, enzima envolvida na síntese de fitoalexina do sorgo, foi efetuado em plântulas, após inoculação com Cochliobolus heterostrophus, não patogênico ao sorgo ou com C. sublineolum. Os resultados obtidos por esses autores sugeriram que eventos de reconhecimento distintos estão envolvidos na expressão da resistência nestas interações. Morris et al. (1998) verificaram que o ASM, ácido salicílico e o INA, conferiram proteção significativa em milho contra Peronosclerospora sorghi, agente causal do míldio. Clones de cDNAs de genes de milho, codificadores das PR-proteínas das famílias PR-1 e PR-5, foram isolados de uma biblioteca de cDNA, através de seleção com sondas específicas, obtidas de genes de cevada e de arroz. A biblioteca de cDNA foi obtida a partir de RNAs isolados de folhas de milho, 3 e 7 dias após o tratamento com o ASM. Os indutores químicos da SAR ativaram a expressão dos genes da SAR, $P R-1$ e PR-5. Estes genes foram, também, coordenadamente ativados após a infecção com o patógeno, atuando como indicadores da resposta de defesa. $\mathrm{Na}$ interação incompatível, os genes $P R-1$ e $P R-5$ foram induzidos mais rapidamente e com maior intensidade, do que na interação compatível (Morris et al., 1998).

A técnica da hibridização subtrativa foi utilizada por Takemoto et al. (2003), para gerar uma biblioteca de cDNA enriquecida de genes induzidos em plantas de fumo, após o tratamento com o elicitor de respostas de defesa, constituído por componentes da parede celular de hifas de $P$. infestans. Foram isolados 19 genes, incluindo aqueles codificadores de PR-proteínas, como $\beta$-1,3-glucanase, ou de proteínas da parede celular vegetal, como a extensina e uma proteína rica em glicina. Os autores verificaram, também, o padrão de expressão desses genes, em resposta ao tratamento com ácido salićlíco e metil jasmonato ou à inoculação com a bactéria Pseudomonas syringae pv. glycinea, não patogênica à $N$. tabacum. Os resultados obtidos indicaram que a ativação da transcrição desses genes é regulada por diferentes moléculas sinalizadoras e que os respectivos produtos estão envolvidos em processos distintos relacionados à resistência.

A técnica de microarranjo ("microarray") tem sido bastante utilizada, para o estudo e comparação da expressão de genes de plantas, induzidos em diferentes condições e após o tratamento com patógenos, elicitores e moléculas sinalizadoras de respostas de defesa, como o ácido salicílico, ácido jasmônico ou metil jasmonato e 
etileno (Wan et al., 2002). Schenk et al. (2000) verificaram mudanças no padrão de expressão de 2.375 genes de A. thaliana examinados simultaneamente por análise de cDNAs através da técnica de microarranjo, após inoculação das plantas com Alternaria brassicicola ou tratamento com ácido salicílico, metil jasmonato e etileno. Foram observadas mudanças em 705 mRNAs em resposta a um ou mais tratamentos. O maior número de genes co-induzidos ou co-reprimidos foram encontrados após tratamentos com metil jasmonato e ácido salicílico, sendo que 50\% dos genes induzidos por etileno foram induzidos por metil jasmonato. Entre esses, foram identificados quatro grupos distintos relacionados à defesa de plantas contra doenças, incluindo genes codificadores de cinco PR-proteínas. Os resultados obtidos evidenciaram a existência de uma rede de interações reguladoras entre as diferentes vias sinalizadoras que ativam respostas de defesa em plantas.

Uma metodologia alternativa para o isolamento de genes diferencialmente expressos foi desenvolvida por Diatchenko et al. (1996). Este método, denominado Hibridização Subtrativa por Supressão (HSS), baseia-se na amplificação preferencial, pela reação em cadeia da polimerase (PCR), de seqüências diferencialmente representadas em duas populações de cDNA, enquanto que o fenômeno da supressão impede a amplificação das seqüências comuns. Distintamente de outros métodos de obtenção de genes diferencialmente expressos, que permitem a identificação de pequena quantidade de genes, como a seleção diferencial ("differential display”), por exemplo, a HSS resulta em uma mini-biblioteca enriquecida destes genes, fornecendo amplo material para a comparação de populações de mRNAs. Dada à sua eficiência, a HSS vem sendo amplamente empregada para a identificação de genes envolvidos em diferentes tipos de câncer e em processos de diferenciação celular. Ainda são poucos os trabalhos na área vegetal que fizeram uso da HSS, entretanto, estes já confirmaram a eficiência desta técnica. Birch et al. (1999) isolaram genes de batata, induzidos nos primeiros estágios da resposta de hipersensibilidade $(\mathrm{RH})$ à $P$. infestans, utilizando a técnica da HSS para gerar uma biblioteca de cDNA enriquecida de seqüências induzidas na RH. As sequiências de cDNA obtidas foram comparadas com aquelas depositadas em bancos de dados internacionais ("National Center for Biotechnology Information", 
NCBI). Os produtos dos genes isolados apresentaram similaridade com moléculas sinalizadoras envolvidas na diferenciação celular, apoptose (morte celular programada) e na transdução de sinal da RH. Esta técnica foi utilizada, também, por Xiong et al. (2001), permitindo a identificação de genes envolvidos na resistência de plantas de arroz contra Pyricularia grisea e por Dellagi et al. (2000), para o isolamento de genes de batata, ativados na interação compatível com a bactéria patogênica E. carotovora. Foi identificado, em batata, um importante fator de transcrição da família WRKY, envolvido na indução de genes codificadores de PR-proteínas. A regulação desse gene foi investigada durante as interações compatíveis e incompatíveis de plantas de batata com P. infestans (Dellagi et al., 2000). Em tomateiro, o gene de resistência Pto confere resistência a bactéria patogênica $P$. syringae pv. tomato, portadora do gene de avirulência avrPto. A superexpressão do gene Pto sob o controle do promotor 35S do vírus do mosaico da couve-flor, ativa nas plantas de tomate, de forma constitutiva, respostas de defesa na ausência de infecção pelo patógeno e aumenta, também, a resistência inespecífica. Para elucidar os mecanismos de resistência, envolvidos nesta interação incompatível, Xiao et al. (2001), empregaram, também, a HSS. A técnica possibilitou o isolamento de 82 clones de cDNAs em plantas de tomate 35S::Pto correspondendo a genes envolvidos em diversos mecanismos de defesa, como transdução de sinal, resposta de hipersensibilidade, estresse oxidativo e proteólise.

Com base nestes resultados foi utilizada, no presente trabalho, a técnica da HSS para o estudo de cafeeiros tratados com o indutor ASM, com o objetivo de identificar genes associados à SAR, como aqueles codificadores de PR-proteínas, de enzimas de vias metabólicas envolvidas na produção de compostos antimicrobianos e de proteínas envolvidas na transdução do sinal que leva à ativação do estado de resistência. $\mathrm{O}$ procedimento da HSS foi utilizado, também, para comparar os mecanismos de respostas de defesa associados à $\mathrm{SAR}$, com a resistência raça-cultivar específica, ativada em cafeeiro resistente após a inoculação com o fungo $H$. vastatrix. Deve ser salientado, que além dos aspectos mencionados, a técnica de HSS permite o enriquecimento de seqüências raras cerca de 1000 vezes (Diatchenko et al., 1996). Os genes associados à resistência em plantas não são expressos de forma abundante após a respectiva ativação, 
ocorrendo a transcrição de um número pequeno de cópias, o que dificulta seu isolamento e caracterização. Portanto, a técnica de HSS foi utilizada no presente estudo, com o objetivo de facilitar a caracterização de genes em cafeeiro associados à respostas de resistência. 


\section{MATERIAL E MÉTODOS}

\subsection{Fonte de material}

\subsubsection{Planta}

Foram utilizadas nos experimentos plantas de:

1- Coffea arabica L. cultivar Mundo Novo linhagem IAC 388-17-1, portadoras do fator de resistência à ferrugem SH5, pertencentes ao grupo fisiológico E, o qual é suscetível à maioria das raças fisiológicas de Hemileia vastatrix Berkeley et Broome, incluindo as mais comuns, II e I (Bettencourt, 1981 e Fazuoli, 1977).

2- Coffea arabica L. x Coffea canephora Pierre, Híbrido de Timor CIFC 832/1, portadoras de fatores de resistência SH5, SH6, SH7, SH8, SH9 à ferrugem do cafeeiro, pertencentes ao grupo fisiológico A, o qual apresenta resistência a todas as raças conhecidas de $H$. vastatrix. O café Híbrido de Timor utilizado é procedente da seleção 832/1 realizada no Centro de Investigação das Ferrugens do Cafeeiro (CIFC, Oeiras, Portugal), sendo derivado de um cruzamento interespecífico natural, provavelmente entre $C$. arabica cultivar Típica e $C$. canephora na Ilha de Timor (Bettencourt, 1984; Rodrigues et al., 1975a e Várzea et al., 2002).

As plantas de C. arabica cv. Mundo Novo foram obtidas a partir de sementes fornecidas pela Cooperativa GARCAFÉ, Garça, SP. O plantio foi feito em uma mistura de terra vegetal e esterco de galinha (250 L/2,5 L), acrescida de 1.250 g de superfosfato simples, 250 g de calcário calcítico e 250 g de cloreto de potássio. As plantas foram mantidas em casa de vegetação, à temperatura ambiente, recebendo adubação mensal por irrigação com solução de sulfato de amônio/ superfosfato simples e cloreto de 
potássio ( $25 \mathrm{~g} / 50 \mathrm{~g} / 10 \mathrm{~g}$ em $10 \mathrm{~L}$ de água para 300 mudas). As plantas foram utilizadas quando atingiram seis a oito pares de folhas totalmente expandidas (cerca de oito meses de idade).

Mudas do germoplasma Híbrido de Timor 832/1 foram gentilmente cedidas pelo Centro de Análise e Pesquisa Tecnológica do Agronegócio do Café "Alcides Carvalho” do Instituto Agronômico de Campinas, Fazenda Santa Elisa, SP (IAC).

\subsubsection{Patógeno}

Urediniosporos de H. vastatrix, raça II, foram coletados na Fazenda Santa Elisa, IAC em Campinas, a partir de plantas de café (cv. Mundo Novo) naturalmente infectadas. Os urediniosporos foram recolhidos com auxílio de um tubo de polietileno, raspando-se suavemente as lesões da superfície abaxial das folhas. Após a coleta, os urediniosporos foram peneirados em peneiras de 0,149 $\mathrm{mm}$ para eliminar impurezas, sendo em seguida acondicionados em criotubos e mantidos em nitrogênio líquido até o uso.

\subsection{Determinação da resistência sistêmica adquirida em cafeeiro suscetível cv. Mundo Novo contra H. vastatrix}

Com a finalidade de avaliar a resistência sistêmica adquirida em cafeeiros suscetíveis contra o patógeno $H$. vastatrix e a indução de proteínas relacionadas à patogênese, após a aplicação de indutor de resistência, foram conduzidos experimentos envolvendo: avaliação de sintomas em plantas de café cv. Mundo Novo inoculadas com H. vastatrix, previamente tratadas com indutor de resistência e detecção das PRproteínas quitinases e $\beta$-1,3-glucanases nas plantas induzidas, através de ensaios enzimáticos.

\subsubsection{Obtenção do indutor de resistência}


O composto éster S-metil do ácido benzo-(1,2,3)-tiadiazole-7-carbotióico, um derivado do benzotiadiazole (acibenzolar-S-metil, ASM), na concentração de $200 \mu \mathrm{g}$ de i.a./mL $(950 \mu \mathrm{M})$ foi utilizado para induzir resistência em cafeeiros suscetíveis cv. Mundo Novo contra H. vastatrix. A suspensão aquosa preparada a partir de formulação comercial em pó molhável contendo $50 \%$ do princípio ativo foi agitada durante 10 min à temperatura ambiente antes da aplicação nas plantas.

\subsubsection{Obtenção do inóculo}

Urediniosporos de $H$. vastatrix, retirados do nitrogênio líquido, foram submetidos a um choque térmico por 10 min pela imersão dos criotubos em água aquecida a $40^{\circ} \mathrm{C}$. Em seguida, foram misturados com água destilada esterilizada para uma concentração de $2 \mathrm{mg} / \mathrm{mL}$. A suspensão, agitada por 10 min e submetida em seguida a ultra-som, $50 \mathrm{~Hz}$ por $30 \mathrm{~s}$ (Sonorex RK 103), foi mantida sob agitação constante durante a inoculação das plantas.

\subsubsection{Indução de resistência local e sistêmica em cv. suscetível Mundo Novo contra H. vastatrix}

Os $2^{\text {os }}$ e $3^{\text {os }}$ pares de folhas de plantas de café cv. Mundo Novo foram lavados com água corrente, considerando-se como primeiro par as folhas logo abaixo da gema apical. Após a secagem das folhas à temperatura ambiente, o indutor foi aspergido apenas nas superfícies abaxiais dos $3^{\text {os }}$ pares de folhas, a partir do ápice, usando como propelente, nitrogênio gasoso ( 0,2 bars). As plantas controle foram aspergidas com água destilada ao invés do indutor. As plantas permaneceram a $\pm 24^{\circ} \mathrm{C}$, em fotoperíodo de 12 h, sob luz fluorescente $\left(7,35 \mathrm{Wm}^{-2}\right)$. Após intervalos de tempo de 0, 1, 2, 3, 7, 14, 21, 28 e 35 dias, as plantas foram submetidas à inoculação com o patógeno para a determinação da indução de resistência local e sistêmica ou à extração de proteínas. Foram utilizados grupos de 15 plantas por tratamento. 


\subsubsection{Inoculação das plantas com o patógeno e avaliação da indução de resistência local e sistêmica}

Para a inoculação das plantas com o patógeno foi utilizada a suspensão de urediniosporos, obtida conforme descrito no item 3.2.2. A suspensão do inóculo foi aspergida nas superfícies abaxiais dos $2^{\text {os }}$ e $3^{\text {os }}$ pares de folhas das plantas controle e das plantas previamente tratadas com o indutor, após os diferentes intervalos de tempo mencionados anteriormente (item 3.2.3.), usando como propelente, nitrogênio gasoso ( 0,2 bars). Grupos de 10 plantas por tratamento foram utilizados para a avaliação da resistência induzida. As plantas inoculadas foram mantidas no escuro por $48 \mathrm{~h}$ em umidade relativa de cerca de $85 \%$, a $\pm 24^{\circ} \mathrm{C}$ e, em seguida, transferidas para casa de vegetação até o aparecimento de sintomas. A avaliação dos sintomas foi feita em cada par de folhas de cada tratamento, 21-24 dias após a inoculação, determinando-se a média do número de lesões por folha. Foi considerada como lesão cada mancha clorótica individualizada. Para auxiliar a visualização das lesões, cada folha analisada foi submersa em água e iluminada com luz incidente. A proteção foi calculada como redução do número de lesões por folha e expressa como porcentagem do controle, de acordo com Moraes et al. (1976).

\subsubsection{Extração de proteínas relacionadas à patogênese}

A metodologia empregada para a extração de proteínas baseou-se naquela utilizada por Moerschbacher (1988) com modificações, tendo em vista aspectos inerentes ao tecido vegetal empregado, como o alto teor de compostos fenólicos presentes em folhas de cafeeiro. Para o estabelecimento do procedimento adotado no presente trabalho foram consideradas, também, algumas características gerais de PRproteínas como, estabilidade em meio ácido, resistência à ação de proteases e localização no espaço intercelular, vacúolo e/ou parede celular.

A extração de proteínas foi feita a partir dos $2^{\text {os }}$ e $3^{\text {os }}$ pares de folhas de plantas controle e de plantas tratadas com ASM, após os diferentes intervalos de tempo do 
tratamento com o indutor, conforme mencionado no item 3.2.3. Foram preparados dois extratos para cada tratamento.

Os $2^{\text {os }}$ e $3^{\text {os }}$ pares de folhas de plantas controle e de plantas tratadas com ASM, em cada intervalo de tempo, foram destacados, separadamente, para extração das proteínas, tendo sido utilizados grupos de cinco plantas para cada tratamento. As folhas foram lavadas com água corrente, seguida de água destilada, e secas suavemente com algodão. Amostras de folhas, $1 \mathrm{~g}$ de peso fresco de cada tratamento, foram imediatamente imersas em nitrogênio líquido e trituradas em almofariz, na presença de 0,5 g de areia do mar puríssima, 0,3 g da resina Dowex 1-X8 (200-400 mesh) e 1,5 g de polivinilpirrolidona insolúvel (PVPP). O material resultante foi transferido para recipiente mantido no gelo e misturado durante 5 min com $10 \mathrm{~mL}$ de tampão borato de sódio 0,1 M (pH 8,8), contendo EDTA 1 mM (ácido etilenodiaminotetraacético), DTT 1 mM (ditiotreitol) e ácido ascórbico 50 mM. Em seguida, os extratos foram centrifugados a $20.000 \mathrm{~g}$, a $4^{\circ} \mathrm{C}$ por $30 \mathrm{~min}$. Os sobrenadantes foram utilizados para a quantificação de proteínas totais e nos ensaios enzimáticos.

Cumpre mencionar que o EDTA, DTT e o ácido ascórbico foram dissolvidos no tampão imediatamente antes do uso e a solução, apresentando um pH final igual a 4,0 foi mantida sob agitação no gelo em recipiente vedado com papel alumínio durante a extração das proteínas. O EDTA foi utilizado como um agente quelante de metais pesados e íons $\mathrm{Ca}^{2+}$ presentes no meio de extração, enquanto que o uso do DTT teve por finalidade proteger contra oxidação, os gupos sulfidrila livres presentes em proteínas (Moerschbacher, 1988). A utilização conjunta de PVPP, ácido ascórbico e da resina Dowex teve por objetivo propiciar a absorção e inibição de oxidação de compostos fenólicos presentes em folhas de cafeeiro e liberados no meio de extração.

\subsubsection{Quantificação de proteínas totais}

A concentração protéica foi determinada em todos os extratos de plantas controle e tratadas com ASM, obtidos após os diferentes intervalos de tempo do tratamento com o indutor, conforme mencionado no item 3.2.5. A quantificação foi feita 
pelo método descrito por Bradford (1976), utilizando-se albumina de soro bovino como padrão. Foram realizadas três determinações para cada extrato foliar, tendo sido preparados dois extratos por tratamento, conforme descrito no item 3.2.5.

\subsubsection{Ensaio enzimático para a determinação da atividade de quitinase}

Para a detecção de PR-proteínas em folhas de cafeeiro após a indução de resistência com ASM, foram determinadas, através de ensaios enzimáticos, as atividades de quitinases e $\beta$-1,3-glucanases em todos os extratos vegetais, obtidos a partir de plantas controle e tratadas com o indutor, conforme descrito no item 3.2.5.

Para a determinação espectrofotométrica das atividades de quitinases nos extratos foi utilizado como substrato uma solução de carboximetilquitina-remazol violeta brilhante (CM-Chitin-RBV 2mg/ml, Loewe Biochemica $\mathrm{GmbH}$ ), de acordo com metodologia desenvolvida por Wirth \& Wolf (1990) e com o procedimento descrito por Guzzo \& Martins (1996). O método baseia-se na hidrólise enzimática do polímero solúvel carboximetilquitina ligado covalentemente ao corante remazol violeta brilhante 5R (CM-Chitin-RBV). Quitinases hidrolisam o polímero liberando oligômeros de quitina marcados com o corante. O polímero não hidrolisado é precipitado pela acidulação do meio de reação e pode ser eliminado por centrifugação, enquanto que os oligômeros menores permanecem em solução e após a centrifugação, conferem ao sobrenadante uma coloração violeta. A intensidade de coloração é quantificada em espectrofotômetro e utilizada para medir a atividade de quitinase.

Foram utilizados nos ensaios $100 \mu \mathrm{l}$ de cada extrato foliar (diluído previamente 1:100), acrescidos de $500 \mu \mathrm{l}$ de tampão acetato de sódio $50 \mathrm{mM} \mathrm{pH} \mathrm{5,0} \mathrm{e} 200 \mu \mathrm{l}$ de substrato. A mistura foi incubada a $38^{\circ} \mathrm{C}$ por $2 \mathrm{~h}$. A reação foi interrompida pela adição de $200 \mu$ de $\mathrm{HCl}$ 2N e resfriamento em gelo por $10 \mathrm{~min}$. O substrato insolúvel não hidrolisado foi removido por centrifugação, durante 5 min a $10.000 \mathrm{~g}$. Em seguida foi determinada, em espectrofotômetro, a absorbância a $550 \mathrm{~nm}$ dos sobrenadantes, contendo oligômeros solúveis de CM-Chitin-RBV, utilizando-se como referência uma mistura de reação sem o extrato foliar. A atividade enzimática foi expressa como 
absorbância a $550 \mathrm{~nm}$ determinada para cada extrato foliar dividida pela concentração protéica presente na mistura de reação, segundo procedimento descrito por Wüstefeld (1993). O conteúdo protéico na mistura de reação pôde ser estimado pela concentração protéica, em $\mu$ g por $\mathrm{mL}$, determinada para cada extrato foliar, conforme mencionado no item 3.2.6. Os valores obtidos (absorbância a $550 \mathrm{~nm}$ por $\mu$ g de proteína) foram ajustados para equivalência a 0,2 $\mu$ g de proteína (Wüstefeld, 1993). Foram realizadas três determinações para cada extrato foliar, tendo sido preparados dois extratos por tratamento, conforme descrito no item 3.2.5.

\subsubsection{Ensaio enzimático para a determinação da atividade de $\beta$-1,3-glucanase}

Para a determinação espectrofotométrica das atividades de $\beta$-1,3-glucanases nos extratos foi utilizado como substrato uma solução de carboximetilcurdlan-remazol azul brilhante (CM-Curdlan-RBB $4 \mathrm{mg} / \mathrm{ml}$, Loewe Biochemica $\mathrm{GmbH}$ ), de acordo com metodologia desenvolvida por Wirth \& Wolf (1992) e com o procedimento descrito por Guzzo \& Martins (1996). O método baseia-se na hidrólise enzimática do polímero solúvel carboximetilcurdlan ( $\beta$-1,3-glucana carboximetilada) ligado covalentemente ao corante remazol azul brilhante (CM-Curdlan-RBB), seguindo um princípio similar ao descrito para a determinação de quitinase no item 3.2.7. Glucanases hidrolisam o polímero, liberando oligômeros de glucana marcados com o corante. A adição de ácido ao meio de reação interrompe a ação enzimática e promove a precipitação do polímero não degradado, o qual é removido por centrifugação. Os fragmentos menores, que se constituem no produto da ação enzimática, permanecem em solução e conferem uma coloração azul ao sobrenadante. A intensidade de coloração é quantificada em espectrofotômetro e utilizada para medir a atividade de glucanase.

Para as reações enzimáticas foram utilizados $200 \mu \mathrm{l}$ de cada extrato foliar, acrescidos de $400 \mu \mathrm{l}$ de tampão acetato de sódio 50 mM pH 5,0 e $200 \mu \mathrm{l}$ de substrato. Após a incubação da mistura, a $40^{\circ} \mathrm{C}$ por 2 h, a reação foi finalizada pela adição de 200 $\mu \mathrm{l}$ de $\mathrm{HCl} 2 \mathrm{~N}$ a cada amostra e resfriamento no gelo por $10 \mathrm{~min}$. As amostras foram 
centrifugadas por 5 min a $10.000 \mathrm{~g}$. A absorbância a $600 \mathrm{~nm}$ dos sobrenadantes foi determinada contra uma referência em espectrofotômetro e foi utilizada para medir a atividade de $\beta$-1,3-glucanase. A referência consistiu de uma mistura de reação sem o extrato foliar. A atividade enzimática foi expressa como absorbância a $600 \mathrm{~nm}$ obtida para cada extrato dividida pela concentração protéica presente na mistura de reação, conforme descrito no item 3.2.7. Os valores obtidos (absorbância a $600 \mathrm{~nm}$ por $\mu \mathrm{g}$ de proteína) foram ajustados para equivalência a $20 \mu \mathrm{g}$ de proteína (Guzzo \& Martins, 1996). Foram realizadas três determinações para cada extrato foliar, tendo sido preparados dois extratos por tratamento, conforme descrito no item 3.2.5.

\subsection{Isolamento de genes de cafeeiro cv. Mundo Novo, associados à resistência sistêmica adquirida}

Com a finalidade de isolar genes relacionados à resistência sistêmica adquirida em cafeeiro após o tratamento com indutor de resistência, foram conduzidos experimentos envolvendo as seguintes etapas: tratamento de plantas de café suscetíveis cv. Mundo Novo com o indutor de resistência ASM; extração de RNA total a partir de folhas de plantas tratadas ou não com o ASM; síntese de DNA complementar (cDNA) a partir de RNA obtido de plantas tratadas e controle; hibridização subtrativa por supressão (HSS) para obtenção de uma mini-biblioteca de cDNA enriquecida de genes expressos especificamente na planta induzida; clonagem e seqüenciamento dos clones obtidos e confirmação da expressão diferencial dos clones, presentes na biblioteca de cDNA subtraída, obtida após a HSS.

\subsubsection{Tratamento das plantas com o indutor de resistência}

Plantas de café cv. Mundo Novo foram tratadas com uma solução de ASM na concentração de $200 \mu$ g de i.a./mL (950 $\mu \mathrm{M})$, preparada em água deionizada, conforme descrito no ítem 3.2.1. Os $2^{\text {os }}$ e $3^{\text {os }}$ pares de folhas das plantas foram lavados com água corrente, e em seguida, após a secagem à temperatura ambiente, o indutor foi aspergido 
nas superfícies abaxiais das folhas, usando como propelente, nitrogênio gasoso (0,2 bars). As plantas controle foram aspergidas com água destilada ao invés do indutor. As plantas permaneceram a $\pm 24^{\circ} \mathrm{C}$, em fotoperíodo de $12 \mathrm{~h}$, sob luz fluorescente $\left(7,35 \mathrm{Wm}^{-}\right.$

${ }^{2}$ ). Após 72 h, foram utilizadas para extração de RNA total. Foram utilizados grupos de quatro plantas por tratamento.

\subsubsection{Extração de RNA total}

Folhas de plantas controle e de plantas tratadas com ASM, conforme descrito no item 3.3.1., foram destacadas separadamente das plantas, 72 h após o tratamento com o indutor, sendo então, lavadas com água corrente, seguida de água deionizada, e secas suavemente com algodão. Amostras de folhas, $100 \mathrm{mg}$ de peso fresco de cada tratamento, foram imediatamente trituradas em almofariz com nitrogênio líquido. O pó fino resultante foi misturado com $1 \mathrm{~mL}$ do reagente TRIzol (Life Technologies, Grand Island, New York) para extração de RNA total, seguindo-se o procedimento descrito em manual do fabricante. O reagente TRIzol é uma solução monofásica de fenol e isotiocianato de guanidina e permite a extração de RNA em uma etapa única, baseandose em método desenvolvido por Chomczynski \& Sacchi (1987).

Após a adição do reagente a cada amostra (100 mg tecido foliar/1 mL de TRIzoL) e homogeneização sob agitação suave, a mistura permaneceu por 5 min à temperatura ambiente para permitir a completa dissociação do complexo núcleoprotéico. O material insolúvel foi removido por centrifugação $\left(12.000 \mathrm{~g}, 10 \mathrm{~min}, 4^{\circ} \mathrm{C}\right)$. Em seguida, após a extração do sobrenadante com 0,2 mL de clorofórmio, o RNA presente na fase aquosa foi precipitado com $0,5 \mathrm{~mL}$ de álcool isopropílico. No final do procedimento, após lavagem do sedimento com $1 \mathrm{~mL}$ de etanol 75\%, seguida de secagem a vácuo (5 min), o RNA extraído foi dissolvido em $50 \mu \mathrm{L}$ de água livre de RNase $\left(55^{\circ} \mathrm{C}, 10 \mathrm{~min}\right)$. A concentração de RNA das amostras foi quantificada em espectrofotômetro a $260 \mathrm{~nm}$. O perfil do RNA extraído foi visualizado por eletroforese em gel de agarose 0,8 \% contendo brometo de etídeo (EtBr), em tampão TAE pH 8,3 
(Tris-ácido acético-EDTA; Tris-acetato $40 \mathrm{mM}$, EDTA 1mM). Todas as amostras de RNA foram mantidas em congelador a $-80^{\circ} \mathrm{C}$.

\subsubsection{Síntese de DNA complementar (cDNA)}

O DNA complementar foi obtido a partir do RNA total extraído de folhas de cafeeiro tratados ou não com ASM, conforme descrito no item 3.3.2., utilizando-se o conjunto de síntese "SMART PCR cDNA Synthesis Kit” (Clontech Laboratories, Palo Alto, Califórnia). O "kit SMART" possibilita a síntese de cDNA de alta qualidade a partir de nanogramas de RNA total ou poli $\mathrm{A}^{+}$, necessário para a construção de biblioteca de cDNA (Chenchik et al., 1998). O método, baseado na reação em cadeia da polimerase (PCR - Polymerization of Chain Reaction), utiliza um primer oligo(dT) modificado, denominado primer CDS e o oligonucleotídeo SMART II para a síntese da primeira fita de cDNA. Enquanto o primer CDS começa a reação de síntese anelando-se logo no início da cauda poli A do RNA mensageiro, o oligonucleotídeo SMART II, que apresenta uma seqüência oligo(G), garante que a transcritase reversa faça a transcrição completa do mRNA até a extremidade 5'. Em seguida, os cDNAs de dupla fita são sintetizados por PCR à longa distância (LD PCR - Long Distance PCR), utilizando-se um primer (primer PCR) que apresenta uma seqüência de nucleotídeos idêntica a uma região comum ao primer CDS e ao SMART II. Esse processo permite a amplificação exponencial apenas dos cDNAs fita simples que apresentam as seqüências complementares completas dos mRNAs presentes na amostra (Figura 1). A síntese de cDNA foi feita segundo as instruções do manual da Clontech "SMART PCR cDNA Synthesis Kit User Manual” (2000b). 


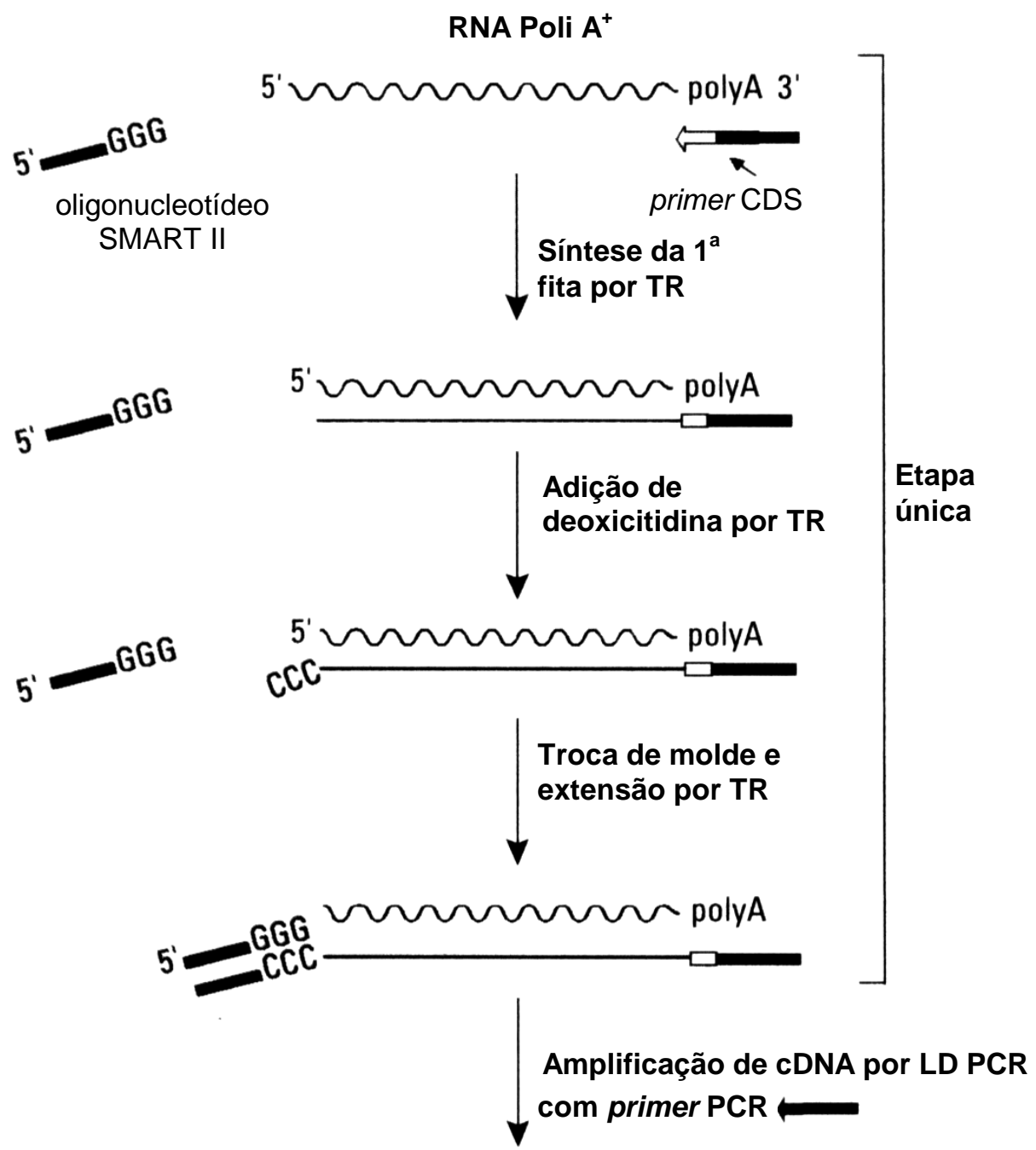

cDNA fita dupla

Figura 1 - Representação diagramática da síntese de cDNA com o kit SMART. O oligonucleotídeo SMART II, o primer CDS e o primer PCR apresentam trechos idênticos de seqüência (س). TR = transcritase reversa. 


\subsubsection{Síntese da primeira fita de cDNA}

Para a síntese da $1^{\mathrm{a}}$ fita de cDNA, 0,870 $\mu$ g de RNA total obtido a partir de folhas de plantas controle ou tratadas com ASM (item 3.3.2.) foram misturadas com 1 $\mu \mathrm{L}$ de primer CDS $10 \mu \mathrm{M}, 1 \mu \mathrm{L}$ do oligonucleotídeo SMART II $10 \mu \mathrm{M}$ e água deionizada para um volume final de $5 \mu \mathrm{L}$. Após incubação a $70^{\circ} \mathrm{C}$ por 2 min em termociclador (Gene Amp PCR System 2400, PerkinElmer, Wellesley, Massachussetts), foram acrescentados a cada mistura, $2 \mu \mathrm{L}$ de tampão- $1^{\text {a }}$ fita $5 \mathrm{X}, 1 \mu \mathrm{L}$ de DTT $20 \mathrm{mM}, 1$ $\mu \mathrm{L}$ de dNTP $10 \mathrm{mM} 50 \mathrm{X}$ (desoxirribonucleosídeo trifosfato) e $1 \mu \mathrm{L}$ de transcritase reversa PowerScript. As amostras foram incubadas a $42^{\circ} \mathrm{C}$ por $1 \mathrm{~h}$ e em seguida, diluídas com $40 \mu \mathrm{L}$ de tampão TE (Tris $10 \mathrm{mM} \mathrm{pH} \mathrm{7,6,} \mathrm{EDTA} 1 \mathrm{mM}$ ). Após aquecimento a $72^{\circ} \mathrm{C}$ por 7 min foi feita a síntese da $2^{\mathrm{a}}$ fita de cDNA por PCR.

\subsubsection{Síntese da segunda fita de cDNA pela reação em cadeia da polimerase à longa distância (LD PCR)}

Amostras de 1,5 $\mu \mathrm{L}$ de cDNA fita simples obtidos de plantas controle ou tratadas com ASM (item 3.3.3.1.) foram diluídas com água deionizada para um volume final de $10 \mu \mathrm{L}$ e utilizadas para a síntese de cDNA dupla fita por LD PCR. A reação de amplificação para cada amostra foi feita com $10 \mu \mathrm{L}$ de tampão PCR $10 \mathrm{X}, 2 \mu \mathrm{L}$ de dNTP 10mM 50 X, $2 \mu \mathrm{L}$ de primer PCR $10 \mu \mathrm{M}, 2 \mu \mathrm{L}$ de advantage polimerase mix 50 $\mathrm{X}$ (preparado especial de Taq DNA polimerase) e $74 \mu \mathrm{L}$ de água deionizada. A amplificação foi realizada em termociclador (PerkinElmer) utilizando-se o programa: $95^{\circ} \mathrm{C}$ por 1 min, seguido de 18 ciclos de $95^{\circ} \mathrm{C}$ por $5 \mathrm{~s}, 65^{\circ} \mathrm{C}$ por $5 \mathrm{~s} \mathrm{e} 68^{\circ} \mathrm{C}$ durante 6 min. Em seguida foi acrescentado a cada amostra, $2 \mu \mathrm{L}$ de EDTA 0,5 M para finalizar a reação. Os produtos de PCR foram visualizados por eletroforese em gel de agarose 1,2 $\% /$ EtBr em tampão TAE. 


\subsubsection{Purificação do cDNA dupla fita}

Os produtos das amplificações contendo os cDNAs dupla fita obtidos de plantas controle ou tratadas com ASM (item 3.3.3.2.) (190 $\mu \mathrm{L} /$ tratamento) foram purificados com o kit de purificação para produto de PCR (“Concert Rapid PCR Purification System”, Life Technologies). Em seguida, foi feita uma purificação subseqüente, em colunas CHROMA SPIN-1000 (Clontech), seguindo as instruções do manual da Clontech “SMART PCR cDNA Synthesis Kit User Manual” (2000b). Os cDNAs dupla fita purificados foram eluídos das colunas com $320 \mu \mathrm{L}$ de tampão TNE (Tris-HCl 10 $\mathrm{mM} \mathrm{pH}$ 8,0, $\mathrm{NaCl} 10 \mathrm{mM}$, EDTA 0,1 mM) e em seguida, visualizados através de eletroforese em gel de agarose 1,2 \%. Os cDNAs de plantas controle e tratadas com ASM obtidos nessa etapa, foram utilizados, em seguida, para a hibridização subtrativa por supressão (HSS).

\subsubsection{Hibridização subtrativa por supressão}

Foi utilizada a HSS para preparar uma mini-biblioteca de cDNA subtraída enriquecida de fragmentos de genes expressos diferencialmente nas plantas de café, induzidas à resistência. A HSS foi realizada com o conjunto para hibridização subtrativa “Clontech PCR-Select cDNA Subtraction Kit” (Clontech Laboratories), a partir dos cDNAs extraídos de folhas de cafeeiros tratados ou não com ASM, conforme descrito no item 3.3.3. A hibridização subtrativa permite a comparação entre duas populações de mRNAs e a obtenção de clones de genes expressos diferencialmente em uma população, após a remoção das seqüências comuns por hibridização. O método de HSS utilizado no presente estudo, baseia-se na amplificação preferencial, por PCR, de seqüências diferencialmente representadas em duas populações de cDNA, enquanto que o fenômeno da supressão impede a amplificação das seqüências comuns (Diatchenko et al., 1996).

As várias etapas da HSS e seu princípio estão representados de forma esquemática na Figura 2. A população de cDNA das plantas tratadas, denominada de tester, é ligada separadamente à dois tipos de adaptadores (adaptador 1 e 2R). A 
população de cDNA de planta controle, denominada driver, não é ligada a qualquer adaptador. Após a desnaturação dos cDNAs tester e driver, os cDNAs da planta controle (driver) são adicionados em excesso a cada uma das duas amostras das plantas tratadas, para a primeira reação de hibridização. Essa reação resulta na formação de diferentes produtos, como a molécula $C$ que representa o híbrido formado entre seqüências de cDNA comuns à planta tratada e ao controle. Para a segunda reação de hibridização, as amostras são misturadas sem desnaturação prévia, juntamente com a adição de um excesso de cDNA desnaturado proveniente de planta controle. Ocorre então, a formação do híbrido $\mathrm{E}$, que representa os cDNAs presentes apenas em plantas induzidas, não comuns às plantas controle. Após o preenchimento das extremidades dos híbridos de cDNAs com os adaptadores, as amostras são submetidas à reação de PCR com primer específico para as seqüências dos adaptadores (PCR primer 1). Apenas os híbridos de cDNA do tipo E que contêm os dois tipos de adaptadores, apresentam os sítios de anelamento para o primer. Esse processo permite, portanto, a amplificação exponencial por PCR apenas dos cDNAs que representam os genes expressos diferencialmente em plantas tratadas. Em seguida, os produtos da reação de PCR são submetidos a uma segunda reação de amplificação (Nested PCR) com os primers específicos Nested PCR primer 1 e Nested PCR primer 2R, correspondentes às regiões mais internas dos adaptadores 1 e 2R, respectivamente. Essa reação possibilita um enriquecimento das seqüências expressas diferencialmente.

A HSS foi feita segundo as instruções do manual da Clontech "CLONTECH PCR-Select cDNA Subtraction Kit User Manual” (2000a). 


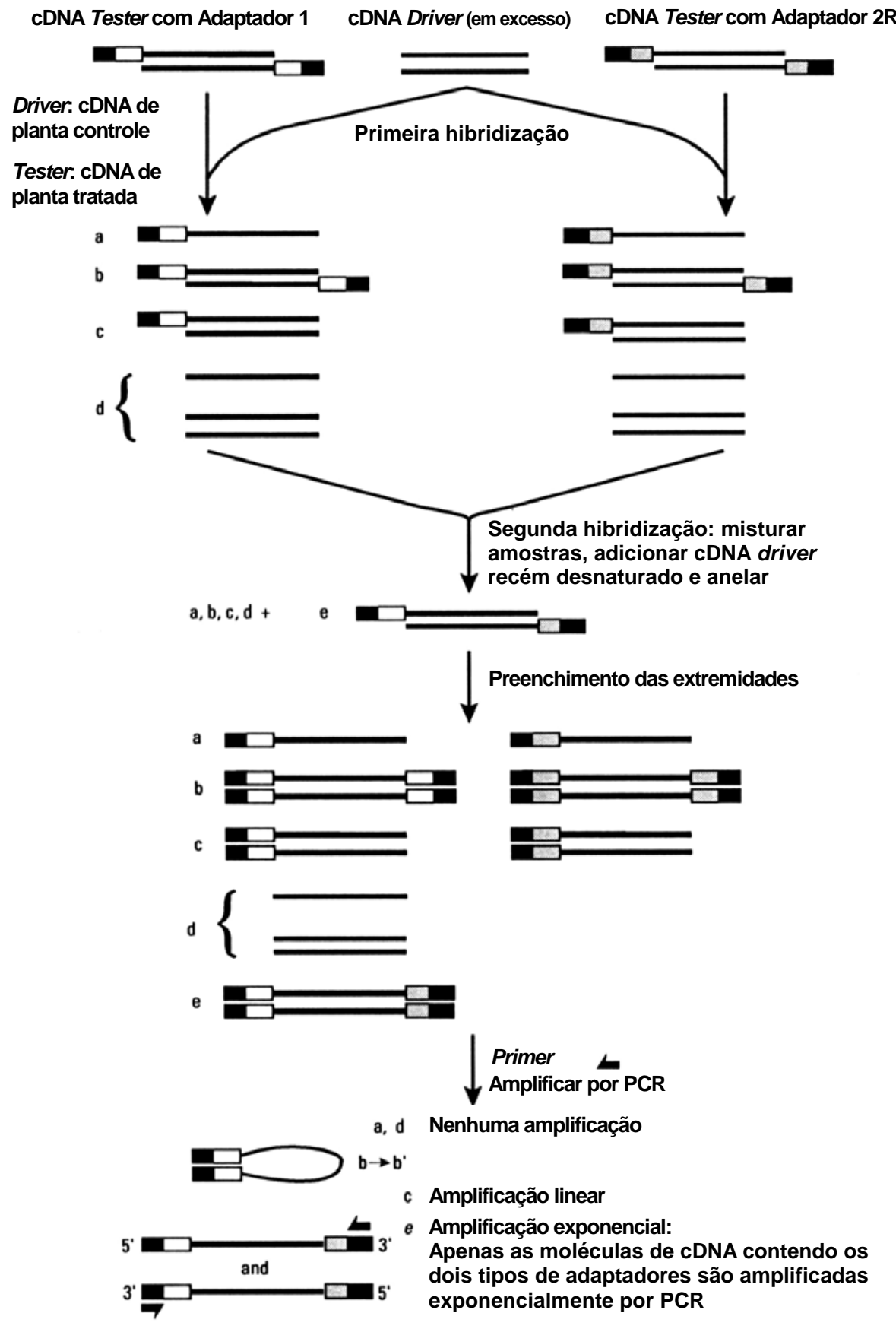

Figura 2 - Representação diagramática da hibridização subtrativa por supressão. As linhas sólidas representam os cDNAs tester ou driver; as caixas sólidas representam a região externa dos adaptadores 1 e 2R que correspondem a seqüência do primer utilizado no PCR (PCR primer 1); as caixas claras representam a região interna do adaptador 1 e da seqüência do Nested PCR primer 1 correspondente; as caixas sombreadas representam a região interna do adaptador $2 \mathrm{R}$ e da seqüência do Nested PCR primer 2R correspondente. 


\subsubsection{Digestão dos cDNAs com a enzima de restrição $R s a$ I}

A HSS requer a utilização de fragmentos menores de cDNA dupla fita apresentando extremidades abruptas, necessários para a ligação dos adaptadores e para a subtração. Amostras de $365 \mu \mathrm{L}$ de cDNA purificados obtidos de plantas controle ou tratadas com ASM (item 3.3.3.3.) foram misturadas com 1,5 $\mu \mathrm{L}$ de enzima de restrição Rsa I e com 40,7 $\mu \mathrm{L}$ de tampão de restrição Rsa I 10 X. Após a incubação das amostras a $37^{\circ} \mathrm{C}$ por $3 \mathrm{~h}$ foi adicionado a cada mistura, $8 \mu \mathrm{L}$ de EDTA 0,5 M para interromper a reação. Em seguida, os produtos da digestão enzimática foram purificados com o kit de purificação “Concert Rapid PCR Purification System” (Life Technologies). As amostras, eluídas com $50 \mu \mathrm{L}$ de tampão $\mathrm{TE}\left(50{ }^{\circ} \mathrm{C}\right)$, foram precipitadas com $50 \mu \mathrm{L}$ de acetato de amônio $4 \mathrm{M}$ e $375 \mu \mathrm{L}$ de etanol 95\%, para concentrar os fragmentos de cDNA purificados. O sedimento de cada amostra foi dissolvido em $6,7 \mu \mathrm{L}$ de tampão TNE e as concentrações de cDNA das amostras de plantas controle ou tratadas com ASM, foram determinadas em espectrofotômetro a $260 \mathrm{~nm}$. Essas amostras foram utilizadas para a ligação com adaptadores e nas reações subseqüentes de hibridização.

\subsubsection{Ligação de adaptadores ao cDNA proveniente de plantas induzidas}

Para a ligação dos adaptadores, uma alíquota de $1 \mu \mathrm{L}$ de amostra de cDNA proveniente de plantas tratadas com ASM obtida conforme descrito no item 3.3.4.1. (digerida com Rsa I, purificada e concentrada) foi diluída com $5 \mu \mathrm{L}$ de água deionizada esterilizada (cDNA tester diluída). Em seguida, a amostra cDNA tester diluída foi ligada separadamente aos dois tipos de adaptadores (adaptador 1 e 2R), preparando-se as seguintes misturas de reação:

a) Mistura de reação Tester1: foram adicionados a $2 \mu \mathrm{L}$ de amostra cDNA tester diluída, $2 \mu \mathrm{L}$ de adaptador $1(10 \mu \mathrm{M}), 3 \mu \mathrm{L}$ de água, $2 \mu \mathrm{L}$ de tampão de ligação 5X e $1 \mu \mathrm{L}$ de T4 DNA ligase (400 unidades/ $\mu \mathrm{L}$ ). 
b) Mistura de reação Tester2: foram adicionados a $2 \mu \mathrm{L}$ de amostra cDNA tester diluída, os mesmos componentes, adicionando-se $2 \mu \mathrm{L}$ de adaptador $2 \mathrm{R}$ $(10 \mu \mathrm{M})$ ao invés do adaptador 1 .

Foi preparada, também, uma amostra contendo $2 \mu \mathrm{L}$ da mistura de reação Tester1 e $2 \mu \mathrm{L}$ da mistura de reação Tester2, denominada, controle tester não-subtraído. Após a reação de ligação, essa amostra foi utilizada como controle da reação de hibridização subtrativa.

A reação de ligação foi realizada em termociclador a $16{ }^{\circ} \mathrm{C}$ durante $14 \mathrm{~h}$, sendo então finalizada pela adição de $1 \mu \mathrm{L}$ de uma mistura de EDTA/glicogênio. As amostras foram aquecidas a $72{ }^{\circ} \mathrm{C}$ por 5 min para inativar a enzima ligase. Em seguida, as amostras Tester1 (ligada ao adaptador 1) e a Tester2 (ligada ao adaptador 2R), foram utilizados na primeira reação de hibridização, enquanto que o controle não-subtraído foi submetido posteriormente à reação de PCR.

\subsubsection{Primeira reação de hibridização}

Para a primeira reação de hibridização foram utilizadas as amostras Tester1ligada ao adaptador 1 e Tester2-ligada ao adaptador 2R (item 3.3.4.2.) e a amostra de cDNA proveniente de plantas controle digerida com Rsa I, purificada e concentrada, conforme descrito no item 3.3.4.1. Essa amostra, denominada cDNA driver, foi adicionada separadamente às amostras tester, preparando-se as seguintes misturas de hibridização:

a) Mistura de hibridização 1: foram misturados $1,5 \mu \mathrm{L}$ de amostra cDNA driver não diluída, $1,5 \mu \mathrm{L}$ de Tester1-ligada ao adaptador 1 e $1 \mu \mathrm{L}$ de tampão de hibridização 4 X.

b) Mistura de hibridização 2: foram misturados $1,5 \mu \mathrm{L}$ de amostra cDNA driver não diluída, 1,5 $\mu \mathrm{L}$ de Tester2-ligada ao adaptador $2 \mathrm{R}$ e $1 \mu \mathrm{L}$ de tampão de hibridização 4 X. 
As misturas de reação foram aquecidas, separadamente, a $98^{\circ} \mathrm{C}$ por 1,5 min, para desnaturação das amostras de cDNAs tester e driver. Em seguida, a primeira reação de hibridização foi realizada em termociclador a $68^{\circ} \mathrm{C}$ por oito horas. Após esse período, os produtos da reação foram imediatamente utilizados para a segunda reação de hibridização.

Nessa etapa, após a desnaturação, ocorre o anelamento entre as seqüências similares de cDNA fita simples presentes nas amostras cDNAs tester e driver. Os cDNAs fita simples remanescentes, disponíveis para a segunda reação de hibridização, representam as seqüências menos abundantes presentes nas duas populações. Dessa forma ocorre a equalização e enriquecimento das seqüências expressas diferencialmente nas plantas induzidas.

\subsubsection{Segunda reação de hibridização}

Na segunda reação de hibridização, as duas amostras provenientes da primeira reação de hibridização foram misturadas e uma alíquota de cDNA driver recém desnaturado foi adicionada à mistura, para propiciar um maior enriquecimento das seqüências expressas diferencialmente. O cDNA driver consistiu de amostra de cDNA proveniente de plantas controle, digerida com Rsa I, purificada e concentrada (item 3.3.4.1.). As seguintes etapas foram executadas:

a) Desnaturação do cDNA driver: foram misturados $1 \mu \mathrm{L}$ de amostra cDNA driver não diluída, $1 \mu \mathrm{L}$ de tampão de hibridização $4 \mathrm{X}$ e $2 \mu \mathrm{L}$ de água esterilizada. Uma alíquota de $1 \mu \mathrm{L}$ dessa mistura foi incubada em termociclador a $98^{\circ} \mathrm{C}$ por $1,5 \mathrm{~min}$.

b) Mistura da segunda reação de hibridização: as amostras de hibridização 1 e 2 provenientes da primeira reação de hibridização foram misturadas sem serem removidas do termociclador e foi adicionada a essa mistura, simultaneamente, o cDNA driver desnaturado (a).

Em seguida, a segunda reação de hibridização foi realizada em termociclador a $68^{\circ} \mathrm{C}$ por quatorze horas. Após esse período, foi adicionado ao produto da reação de 
hibridização, $200 \mu \mathrm{L}$ de tampão de diluição (HEPES-HCl 20 mM pH 8,3, NaCl 50 mM e EDTA 0,2 mM pH 8,0). A mistura foi incubada em termociclador a $68^{\circ} \mathrm{C}$ por $7 \mathrm{~min}$ e utilizada nas reações de PCR.

Nessa etapa ocorre a formação de novas moléculas híbridas que consistem nos cDNAs expressos diferencialmente nas plantas induzidas, apresentando os dois tipos de adaptadores em cada extremidade.

\subsubsection{Primeira amplificação do produto da hibridização pela reação em cadeia da polimerase}

Os cDNAs expressos diferencialmente nas plantas induzidas presentes no produto da segunda reação de hibridização foram amplificados seletivamente por PCR. Na primeira reação de amplificação, apenas os cDNAs dupla fita apresentando em cada extremidade as seqüências distintas de adaptadores foram amplificadas exponencialmente. A reação de amplificação foi feita com o produto da segunda reação de hibridização constituído pelo cDNA tester subtraído (item 3.3.4.4.) e, também, com o controle tester não-subtraído obtido conforme descrito no item 3.3.4.2. As seguintes misturas de reação foram preparadas:

a) Mistura para amplificação da amostra subtraída: foram misturados 1

$\mu \mathrm{L}$ de cDNA tester subtraído e diluído conforme item 3.3.4.4., 19,5 $\mu \mathrm{L}$ de água esterilizada, 2,5 $\mu \mathrm{L}$ de tampão de PCR 10X, 0,5 $\mu \mathrm{L}$ de dNTP mix (10 mM), $1 \mu \mathrm{L}$ de PCR primer $1(10 \mu \mathrm{M})$ e $0,5 \mu \mathrm{L}$ de polimerase cDNA mix $50 \mathrm{X}$ (preparado especial de Taq DNA polimerase).

b) Mistura para amplificação do controle não-subtraído: uma alíquota de $1 \mu \mathrm{L}$ do controle tester não-subtraído (item 3.3.4.2.) foi diluída em $1 \mathrm{~mL}$ de água esterilizada. Em seguida, foram adicionados a $1 \mu \mathrm{L}$ dessa amostra diluída, os mesmos componentes de reação de PCR.

As misturas de reação foram incubadas em termociclador a $75^{\circ} \mathrm{C}$ por 5 min para a extensão dos adaptadores. Imediatamente foi realizada a amplificação utilizando-se o 
programa: $94^{\circ} \mathrm{C}$ por $25 \mathrm{~s}$, seguido de 27 ciclos de $94^{\circ} \mathrm{C}$ por $10 \mathrm{~s}, 66^{\circ} \mathrm{C}$ por $30 \mathrm{~s}$ e $72^{\circ} \mathrm{C}$ durante 1,5 min. Em seguida, $3 \mu \mathrm{L}$ de cada produto do primeiro PCR foram misturados com $27 \mu \mathrm{L}$ de água e as amostras assim diluídas foram utilizadas na segunda reação de amplificação (Nested PCR) ou posteriormente, no procedimento da seleção diferencial. Os produtos de PCR foram visualizados por eletroforese em gel de agarose 1,5 \%/EtBr em tampão TAE.

\subsubsection{Segunda amplificação pela reação em cadeia da polimerase}

Para a segunda reação de amplificação, $1 \mu \mathrm{L}$ do produto do primeiro PCR diluído, obtido para cada amostra conforme descrito no item 3.3.4.5., foi misturado com 18,5 $\mu \mathrm{L}$ de água esterilizada, 2,5 $\mu \mathrm{L}$ de tampão de PCR 10X, $1 \mu \mathrm{L}$ de Nested PCR primer $1(10 \mu \mathrm{M}), 1 \mu \mathrm{L}$ de Nested PCR primer $2 \mathrm{R}(10 \mu \mathrm{M}), 0,5 \mu \mathrm{L}$ de dNTP mix $(10$ $\mathrm{mM}$ ) e $0,5 \mu \mathrm{L}$ de advantage polimerase cDNA mix $50 \mathrm{X}$ (preparado especial de Taq DNA polimerase).

A reação de amplificação foi realizada utilizando-se o programa: 10 ciclos de $94^{\circ} \mathrm{C}$ por $10 \mathrm{~s}, 68^{\circ} \mathrm{C}$ por $30 \mathrm{~s}$ e $72^{\circ} \mathrm{C}$ durante $1,5 \mathrm{~min}$. Essa etapa possibilitou um enriquecimento das seqüências de cDNAs expressas diferencialmente.

Os produtos do segundo PCR foram visualizados por eletroforese em gel de agarose 1,5 \%/EtBr em tampão TAE e purificados com o kit de purificação “Concert Rapid PCR Purification System” (Life Technologies). Em seguida, foram submetidos à clonagem para obtenção da mini-biblioteca de cDNA de genes obtidos de plantas induzidas.

Essa hibridização subtrativa foi realizada utilizando-se como amostra tester os cDNAs obtidos de plantas tratadas, os quais foram subtraídos com os cDNAs da planta controle (cDNAs driver). Esse tipo de hibridização é denominado de subtração forward (SF). Foi realizada, também, uma hibridização inversa, denominada de subtração reverse (SR), onde os cDNAs da planta controle foram utilizados como amostra tester, sendo subtraídos com os cDNAs da planta induzida, os quais foram utilizados como driver. 
Para a subtração reverse foram seguidas as mesmas etapas descritas a partir do item 3.3.4.2, sendo realizada simultaneamente com a subtração forward. A realização da subtração reversa é necessária para o procedimento da seleção diferencial.

\subsubsection{Clonagem do produto final da hibridização subtrativa por supressão no vetor pGEM-T Easy}

O produto purificado do segundo PCR proveniente da HSS forward, contendo os fragmentos de cDNAs de plantas de café tratadas com ASM, após subtração com os cDNAs das plantas controle não tratadas (I-SF, item 3.3.4.6.), foi submetido à clonagem no vetor pGEM-T Easy (Promega, Madison, Wisconsin). O vetor pGEM-T Easy, adequado para clonagem de produtos de PCR, apresenta sítios de reconhecimento para várias enzimas de restrição.

A reação de ligação ao vetor foi realizada a $4^{\circ} \mathrm{C}$ por 16 horas misturando-se 1 $\mu \mathrm{L}$ da amostra I-SF diluída cinco vezes, $2 \mu \mathrm{L}$ de água deionizada, $5 \mu \mathrm{L}$ de tampão de ligação 2 X, $1 \mu \mathrm{L}$ de pGEM-T Easy e $1 \mu \mathrm{L}$ da enzima T4 DNA ligase (3 unidades/ $\mu \mathrm{L}$ ).

\subsubsection{Transformação por eletroporação em células competentes de Escherichia coli}

O produto da ligação com o vetor, obtido no item 3.3.5., foi precipitado com 1 $\mu \mathrm{L}$ de acetato de sódio $3 \mathrm{M} \mathrm{pH} \mathrm{5,2} \mathrm{e} 25 \mu \mathrm{L}$ de etanol $96 \%$ durante $1 \mathrm{~h}$ a $-80^{\circ} \mathrm{C}$. Após a centrifugação da amostra (20 min, $12.000 \mathrm{~g}, 4^{\circ} \mathrm{C}$ ), o sedimento foi lavado com etanol 70 \% e submetido à secagem a vácuo por 5 min. Em seguida, o sedimento foi dissolvido com $2 \mu \mathrm{L}$ de água deionizada esterilizada e misturado no gelo com $20 \mu \mathrm{L}$ de células eletrocompetentes de Escherichia coli cepa DH $5 \alpha$, preparadas segundo o procedimento descrito por Sambrook \& Russell (2001). As células de E. coli foram, então, transformadas com o produto da reação de ligação utilizando-se um eletroporador (CellPorator E. coli Pulser, Life Technologies). Após o choque elétrico, as células foram misturadas com $1 \mathrm{~mL}$ de meio de cultura líquido Luria-Bertani (LB) e a suspensão foi 
mantida sob agitação a $37^{\circ} \mathrm{C}$ durante 50 min. Em seguida, a suspensão celular foi plaqueada em meio sólido LB contendo ampicilina (100 mg/1 L), utilizando-se alíquotas de $200 \mu \mathrm{L}$ de suspensão por placa de Petri. Quinze minutos antes da adição das células de $E$. coli ao meio sólido, foram espalhados em cada placa, $5 \mu \mathrm{L}$ de X-Gal (5-bromo-4cloro-3-indolil- $\beta$-D-galactosídeo) e $50 \mu \mathrm{L}$ de $\quad$ IPTG (isopropil- $\beta$-Dtiogalactopiranosídeo, indutor do operon Lac de E. coli). Após o plaqueamento, as culturas foram mantidas a $37^{\circ} \mathrm{C}$ durante 15 horas para permitir o crescimento das colônias bacterianas. A presença de antibiótico no meio de cultura possibilita apenas o crescimento das células de E. coli transformadas, contendo o vetor. Por outro lado, as colônias transformadas, mas apresentando o vetor sem inserto de cDNA podem ser diferenciadas das demais, devido à coloração azul resultante de reação da enzima $\beta$ galactosidase com o substrato X-Gal. Após esse período, as colônias brancas transformadas foram coletadas com auxilio de palitos esterilizados, sendo transferidas individualmente para blocos de 96 cavidades contendo por poço, $1 \mathrm{~mL}$ de meio LB líquido com ampicilina (100 $\mu \mathrm{g} / \mathrm{mL}$ ). Em seguida, os blocos foram mantidos a $37^{\circ} \mathrm{C}$ sob agitação durante 22 h, em agitador orbital (Forma Scientific, Marietta, Ohio) ajustado para 300 rpm, para possibilitar o crescimento das células de E.coli. Para a produção da mini-biblioteca de cDNA de genes obtidos de plantas induzidas foram preparados quatro blocos, perfazendo um total de 384 clones.

Após o período de 22 h, antes de ser efetuada a extração dos plasmídeos das células bacterianas, os clones foram conservados em glicerol, para o armazenamento permanente da biblioteca obtida. Com auxílio de um aplicador de metal, as culturas de E. coli foram separadamente transferidas dos blocos para placas esterilizadas de 96 cavidades contendo por poço $100 \mu \mathrm{L}$ de meio de cultura liquido LB, acrescido de glicerol 12,5\% e ampicilina (100 $\mu \mathrm{g} / \mathrm{mL})$. Após $24 \mathrm{~h}$, as placas foram mantidas em congelador a $-80^{\circ} \mathrm{C}$. 


\subsubsection{Extração dos plasmídeos dos clones obtidos}

Os plasmídeos foram extraídos das células bacterianas por lise alcalina, baseando-se em método desenvolvido por Birnboim \& Doly (1979). Foi adotado o procedimento para preparação de plasmídeos em microplacas, utilizando-se os clones obtidos conforme descrito no item 3.3.6.

Após o crescimento das colônias por um período de 22 h (item 3.3.6.), os blocos de 96 poços cada foram submetidos à centrifugação por 6 min a $20^{\circ} \mathrm{C}, 4.000 \mathrm{rpm}$, para sedimentação das células bacterianas. Em seguida, o meio de cultura foi descartado e os blocos foram invertidos sobre papel absorvente por $5 \mathrm{~min}$. As células sedimentadas foram lavadas sob agitação por 5 min, com uma solução de glicose, EDTA e Tris-HCl (GET: glicose 50 mM, EDTA $10 \mathrm{mM} \mathrm{pH} \mathrm{8,0,} \mathrm{Tris-HCl} 50 \mathrm{mM} \mathrm{pH} \mathrm{7,4),} \mathrm{adicionando-se}$ $240 \mu \mathrm{L}$ de GET por poço. Após centrifugação a $4.000 \mathrm{rpm}$ por $6 \mathrm{~min}, 20^{\circ} \mathrm{C}$, o sobrenadante foi descartado e os blocos foram novamente invertidos sobre papel absorvente por $5 \mathrm{~min}$. Em seguida, as células bacterianas foram ressuspendidas sob agitação por 5 min, adicionando-se a cada poço, $80 \mu \mathrm{L}$ de solução GET misturada com 2,5 $\mu \mathrm{L}$ de RNase (10 mg/mL). Alíquotas de $60 \mu \mathrm{L}$ de cada suspensão de células foram transferidas separadamente para microplacas de polipropileno, contendo 96 poços com cavidades de $250 \mu \mathrm{L}$ com fundo em U. Para a lise celular, foi adicionado a cada poço, 60 $\mu \mathrm{L}$ de uma solução de $\mathrm{NaOH}$ 0,2 N/SDS 1\% (dodecil sulfato de sódio). As placas foram vedadas com adesivo, agitadas manualmente e mantidas por 10 min em temperatura ambiente. Após centrifugação a $20^{\circ} \mathrm{C}, 4.000 \mathrm{rpm}$ por $1 \mathrm{~min}$, foram adicionados a cada poço, $60 \mu \mathrm{L}$ de uma solução de acetato de potássio $3 \mathrm{M} \mathrm{pH} \mathrm{5,2.} \mathrm{As} \mathrm{placas} \mathrm{foram} \mathrm{agitadas}$ manualmente por inversão e mantidas em temperatura ambiente por 10 min. Em seguida, após nova centrifugação a $20^{\circ} \mathrm{C}, 4.000 \mathrm{rpm}$ por $1 \mathrm{~min}$, as placas foram incubadas a $90^{\circ} \mathrm{C}$ durante $30 \mathrm{~min}$. Após resfriamento em gelo por $10 \mathrm{~min}$, as placas foram centrifugadas por $4 \mathrm{~min}$ a $4.000 \mathrm{rpm}, 20^{\circ} \mathrm{C}$. Essa etapa permite a separação entre o DNA genômico e o DNA plasmidial. Enquanto o DNA genômico é desnaturado e 
retido no sedimento com os resíduos celulares, o DNA plasmidial permanece solúvel no sobrenadante.

O volume total de cada sobrenadante foi transferido para placas de filtro Millipore 0,22 $\mu \mathrm{m}$ fixadas sobre microplacas de polipropileno de fundo em $\mathrm{V}$, contendo 96 cavidades. $\mathrm{O}$ conjunto foi centrifugado por $4 \mathrm{~min}$ a $4.000 \mathrm{rpm}, 20^{\circ} \mathrm{C}$, para possibilitar a filtração do DNA plasmidial extraído, o qual foi concentrado através da adição de 110 $\mu \mathrm{L}$ de isopropanol a cada filtrado presente nas placas de polipropileno. Em seguida, as placas foram vedadas com adesivo, agitadas manualmente por inversão e centrifugadas durante $45 \mathrm{~min}$ a $4.000 \mathrm{rpm}, 20^{\circ} \mathrm{C}$. Após a remoção dos sobrenadantes, os sedimentos foram lavados com $200 \mu \mathrm{L}$ de etanol $70 \%$ e as placas foram centrifugadas por 5 min a $4.000 \mathrm{rpm}, 20^{\circ} \mathrm{C}$. O sobrenadante foi descartado e as microplacas foram novamente centrifugadas de forma invertida sobre papel absorvente, para remover o excesso de etanol, sendo, em seguida, mantidas a $37^{\circ} \mathrm{C}$ por 10 min para secagem completa. O DNA foi dissolvido, acrescentando-se $40 \mu \mathrm{L}$ de água deionizada em cada poço e as microplacas permaneceram a temperatura ambiente durante cerca de $14 \mathrm{~h}$, para propiciar uma dissolução completa. Em seguida, os plasmídeos extraídos foram mantidos a $-20^{\circ} \mathrm{C}$ e submetidos a seqüenciamento. Posteriormente, foram utilizados, também, para confirmar a expressão diferencial dos clones de cDNA, através da técnica de seleção diferencial.

\subsubsection{Seqüenciamento dos plasmídeos da mini-biblioteca de cDNA de genes obtidos de plantas induzidas}

Os plasmídeos contendo os insertos de cDNA, extraídos dos 384 clones obtidos, conforme descrito no item 3.3.7. foram seqüenciados em aparelho seqüenciador de DNA, ABI PRISM 377 (Applied Biosystems, Foster City, Califórnia). Para o seqüenciamento foi utilizado o método enzimático baseado na síntese de DNA in vitro na presença de nucleosídeos trifosfatados terminadores de cadeia (Sanger et al., 1977). Os cDNAs purificados foram amplificados por PCR na presença de DNA polimerase, de 
um primer universal que se anela à seqüência do vetor utilizado para a clonagem, de dNTPs em excesso e de uma pequena quantidade de didesoxirribonucleosídeos trifosfatos terminadores de cadeia (ddNTPs), marcados com substância fluorescente (diclororhodamina ligada à fluoresceína). Quando ddNTPs (ddATP, ddTTP, ddCTP e ddGTP), os quais não apresentam o grupo 3’-OH da desoxirribose presente em nucleotídeos normais, são aleatoriamente incorporados na cadeia de DNA que está sendo sintetizada, a adição do nucleosídeo seguinte é bloqueada. Dessa forma, a reação enzimática gera fragmentos de DNA marcados com substância fluorescente, os quais são posteriormente separados por eletroforese e detectados, permitindo a determinação da seqüência completa da fita molde de DNA. O seqüenciamento foi realizado com o kit “Big Dye Terminator” (Applied Biosystems).

Para a reação de seqüenciamento foram adicionados a uma microplaca para PCR contendo 96 cavidades, $2 \mu \mathrm{L}$ de cada plasmídeo e $8 \mu \mathrm{L}$ de "Big Dye Terminator" (DNA polimerase/dNTPs/ddNTPs) diluído $4 \mathrm{X}$ no tampão de seqüenciamento "save money” (Tris-HCl 50mM/cloreto de magnésio 1,25 mM), acrescido de 3,3 picomoles de primer forward T7. A reação foi realizada em termociclador (PTC-200 Peltier Thermal Cycler, MJ Research, Waltham, Massachussetts) utilizando-se o seguinte programa: $96^{\circ} \mathrm{C}$ por $90 \mathrm{~s}$ para desnaturação inicial do DNA, seguido de 24 ciclos de $96^{\circ} \mathrm{C}$ por $15 \mathrm{~s}$, $50^{\circ} \mathrm{C}$ por $30 \mathrm{~s}$ e $60^{\circ} \mathrm{C}$ durante $4 \mathrm{~min}$.

Os produtos amplificados da reação de seqüenciamento foram concentrados, adicionando-se $40 \mu \mathrm{L}$ de isopropanol 75\% às amostras em cada cavidade da microplaca de PCR. Em seguida, as placas foram vedadas com adesivo, agitadas manualmente por inversão, permanecendo à temperatura ambiente por 15 min. Após centrifugação por 30 min a $4.000 \mathrm{rpm}, 20^{\circ} \mathrm{C}$, os sobrenadantes foram descartados e os sedimentos foram lavados com $150 \mu \mathrm{L}$ de isopropanol 75\%. As placas foram centrifugadas por $10 \mathrm{~min}$ a $4.000 \mathrm{rpm}, 20^{\circ} \mathrm{C}$. Os sobrenadantes foram descartados e as microplacas foram novamente centrifugadas de forma invertida sobre papel absorvente (1.000 rpm, $1 \mathrm{~min}$ ) para remover o excesso de isopropanol, sendo, em seguida, mantidas a $37^{\circ} \mathrm{C}$ por 10 min para secagem. 
Após adicionar $3 \mu \mathrm{L}$ de tampão de amostra (TBE: Tris-HCl/ácido bórico/EDTA contendo formamida e azul de dextrana) em cada poço da microplaca, os produtos da reação de seqüenciamento foram desnaturados em termociclador por 2 min a $95^{\circ} \mathrm{C}$ e as microplacas foram imediatamente colocadas no gelo. Os fragmentos de cDNAs marcados foram separados por eletroforese em gel desnaturante de poliacrilamida 5\% contendo uréia (35\%), sendo realizada em seqüenciador automático ABI 377, seguindose o procedimento descrito em manual do fabricante (ABI PRISM 377 DNA Sequencer Manual). Foram aplicadas alíquotas de $1 \mu \mathrm{L}$ de cada amostra a géis de 96 poços e as seqüências foram determinadas utilizando-se o programa Sequencer Analyser 3.1.

\subsubsection{Avaliação da função dos genes isolados de cafeeiro Mundo Novo tratado com indutor de resistência}

As seqüências dos 384 clones de cDNAs de genes isolados de plantas tratadas com indutor de resistência, determinadas conforme descrito no item 3.3.8., foram comparadas com aquelas presentes em bancos de dados internacionais ("National Center for Biotechnology Information”, NCBI). A função de cada gene de cafeeiro foi detectada por comparação com seqüências homólogas do NCBI, utilizando-se o programa BlastX (Altschul et al., 1997). Após cada seqüência de cDNA isolada de cafeeiro ter sido submetida à analise, foi avaliada a relação de seqüências mais similares de genes presentes no GenBank, encontradas pelo programa. Foi atribuída para cada clone de cDNA analisado, a função associada à seqüência de maior homologia detectada, sendo referida juntamente com a espécie do organismo utilizado para o isolamento do gene e o respectivo número de acesso do GenBank. O valor de $\mathrm{E}$ (“expectation value”), o qual representa a probabilidade de que a homologia encontrada seja devido ao acaso, foi utilizado para indicar a significância da similaridade de seqüência encontrada para cada gene. Nelson et al. (1997) estabeleceu três classes para descrever o nível de significância encontrado para as seqüências expressas, isoladas de Neurospora crassa ("expressed sequence tags", ESTs). As classes foram definidas como: altamente significativas, $P<10^{-19}$; moderadamente significativas, $P=10^{-5}$ a $10^{-19}$; 
e fracamente significativas, $P=10^{-2}$ a $10^{-4}$. Birch et al. (1999) adotaram essa escala, para avaliar as significâncias encontradas através do programa BLAST, das funções de genes de batata isolados por HSS, associados à resposta de hipersensibilidade. No presente estudo, portanto, homologias com seqüências do GenBank apresentando valores de E maiores do que $10^{-3}$ (1e-03) não foram consideradas significativas.

Foi realizada, também, uma análise de possíveis domínios presentes nas proteínas codificadas pelos genes isolados de cafeeiro, através de busca no banco de dados para domínios conservados, disponível no NCBI ("Conserved domain database and Search Service, v 1.63, CD-Search”, NCBI) (Marchler-Bauer et al., 2003). Foram submetidas à análise, as seqüências de aminoácidos deduzidas a partir das seqüências de nucleotídeos dos clones de cDNAs de cafeeiro, através do programa "Six frame translation, Sequence Utilities-BCM Search Launcher” (Baylor College of Medicine HGSC, http://searchlauncher.bcm.tmc.edu/seq-util/seq-util.html) (Smith et al., 1996).

\subsubsection{Confirmação da ativação da expressão de genes na planta induzida, por seleção diferencial}

Com a finalidade de confirmar a expressão diferencial dos clones de cDNA, presentes na biblioteca subtraída obtida após a HSS, enriquecida de fragmentos de genes isolados de plantas de café induzidas à resistência, foi utilizada técnica de seleção diferencial. Conforme já mencionado, a HSS permite o isolamento de genes expressos diferencialmente em uma população e a obtenção de uma mini-biblioteca de cDNA enriquecida destes genes, fornecendo amplo material para a comparação de populações distintas de mRNAs. Entretanto, apesar de sua eficiência, pode ocorrer a presença na amostra subtraída, de cDNAs comuns às duas populações distintas utilizadas na hibridização subtrativa, os quais não foram removidos após a subtração. Assim, se faz necessário o uso de uma técnica adicional, para confirmar a expressão diferencial dos genes isolados após a HSS.

No presente trabalho, foi realizada a seleção diferencial dos 384 clones da biblioteca obtida após a subtração forward (SF) (item 3.3.4.6., item 3.3.7.), através de 
hibridização com sondas de cDNAs de plantas tratadas (ASM) e controle, marcadas com digoxigenina (Roche Diagnostics GmbH, Roche Molecular Biochemicals, Mannheim). A digoxigenina é um hapteno esterol que pode ser incorporada em moléculas de ácido nucléico, permitindo a marcação eficiente de sondas de RNA ou DNA por método não radioativo. A seleção diferencial foi realizada utilizando-se o método de arranjo de cDNA ("cDNA array"), baseando-se em metodologia descrita no manual da Clontech "PCR-Select Differential Screening Kit User Manual” (2001a). As hibridizações foram realizadas seguindo a metodologia descrita no manual da Roche "DIG Application Manual for Filter Hybridization" (2000) e utilizando-se o kit "DIG High Prime DNA Labeling and Detection Starter Kit II” (Roche Molecular Biochemicals).

\subsubsection{Desnaturação com hidróxido de sódio dos cDNAs da biblioteca subtraída}

Alíquotas de $2 \mu \mathrm{L}$ de cDNAs extraídos dos 384 clones (item 3.3.7.) da minibiblioteca subtraída obtida de plantas induzidas (SF) foram adicionadas a microplacas esterilizadas contendo 96 cavidades. Em seguida, foram adicionados em cada poço das microplacas, $3 \mu \mathrm{L}$ de água deionizada esterilizada e $5 \mu \mathrm{L}$ de solução de $\mathrm{NaOH}$ 0,6 N, recém preparada, para desnaturação dos cDNAs. Após rápida centrifugação das microplacas para misturar as amostras, alíquotas de $2 \mu \mathrm{L}$ de cada cavidade foram aplicadas em membranas de nylon positivamente carregadas (Roche), com auxílio de micropipetas multicanal. As membranas foram mantidas a $37^{\circ} \mathrm{C}$ por 5 min para secagem das amostras. Em seguida, foram lavadas com solução tampão Tris-HCl 0,5 M pH 7,5 durante 2 min para neutralizar o hidróxido de sódio adicionado.

Foram preparadas para cada conjunto de 96 clones duas membranas iguais, que foram posteriormente submetidas à hibridização com dois tipos de sonda: sondas de cDNAs isolados de plantas tratadas (ASM) ou sondas de cDNAs de plantas controle, marcadas com digoxigenina.

\subsubsection{Fixação por ultravioleta, dos cDNAs aplicados à membranas de nylon}


As membranas contendo os cDNAs já desnaturados, foram lavadas com água deionizada esterilizada e colocadas sobre papéis de filtro previamente embebidos em solução tampão SSC 2 X (citrato de sódio 30 mM pH 7,0 contendo $\mathrm{NaCl}$ 0,3 M). Em seguida, as membranas foram expostas à luz ultravioleta por 3 min para fixação dos cDNAs, colocando-se o conjunto sobre a superfície de aparelho transiluminador (“Electronic UV Transilluminator, Ultra-Lum, Carson, Califórnia). Após rápida lavagem das membranas em água esterilizada, as mesmas foram mantidas a $37^{\circ} \mathrm{C}$ por 10 min para secagem. Os cDNAs fixados nas membranas foram submetidos à hibridização com sondas marcadas com digoxigenina.

\subsubsection{Preparo e marcação das sondas de cDNAs com digoxigenina}

Foram utilizados como sondas, os produtos de amplificação do segundo PCR purificados provenientes da HSS forward e reverse, constituindo-se nas sondas induzida e controle, respectivamente. A sonda controle consistiu, portanto, de cDNAs de plantas de café não tratadas, após subtração com os cDNAs das plantas induzidas à resistência (C-SR) (produtos da subtração reverse, SR). A sonda induzida consistiu de cDNAs de plantas de café induzidas à resistência com ASM, após subtração com os cDNAs das plantas controle não tratadas (I-SF) (produtos da subtração forward, SF). Para o preparo das sondas, os produtos de amplificação do primeiro PCR da HSS (SF e SR) obtidos conforme o item 3.3.4.5., foram submetidos ao segundo PCR em condições iguais às já descritas (3.3.4.6.), com exceção da reação de amplificação, que foi realizada utilizandose o programa: 12 ciclos de $94^{\circ} \mathrm{C}$ por $10 \mathrm{~s}, 68^{\circ} \mathrm{C}$ por $30 \mathrm{~s}$ e $72^{\circ} \mathrm{C}$ por $1,5 \mathrm{~min}$, seguido por um ciclo adicional de $72{ }^{\circ} \mathrm{C}$ durante 5 min. Em seguida, os produtos da reação de amplificação foram submetidos à digestão com a enzima de restrição Rsa I a $37^{\circ} \mathrm{C}$ por 3 horas, para remoção dos adaptadores utilizados na HSS. As amostras foram, então, purificadas com o kit “Concert Rapid PCR Purification System” (Life Technologies).

As sondas de cDNAs utilizadas na hibridização foram preparadas por incorporação com digoxigenina através do método de marcação randômica ("random primed labbeling”), empregando-se o kit "DIG High Prime DNA Labeling and 
Detection Starter Kit II" (Roche). O "DIG High Prime” consiste de uma mistura de dNTPs, primers randômicos, digoxigenina-11-dUTP (DIG-dUTP) e de enzima Klenow. Nesse procedimento, os cDNAs são marcados através da ação da enzima Klenow, a qual copia moldes do DNA na presença de oligonucleotídeos hexâmeros e DIG-dUTP, inserindo uma porção de digoxigenina a cada 20/25 nucleotídeos.

Alíquotas de $16 \mu \mathrm{L}$ de amostras contendo $1 \mu \mathrm{g}$ de cDNA C-SR ou I-SF (após remoção dos adaptadores e purificação) foram submetidas à fervura por 10 min e imediatamente resfriadas em gelo. Após adição a cada amostra de $4 \mu \mathrm{L}$ de "DIG High Prime”, as misturas foram incubadas em termociclador a $37^{\circ} \mathrm{C}$ durante 16 horas. Em seguida, após a adição de $2 \mu \mathrm{L}$ de EDTA 0,2 M pH 8,0, as amostras foram mantidas a $65^{\circ} \mathrm{C}$ por 10 min, para interromper a reação de incorporação da digoxigenina. As sondas marcadas foram imediatamente utilizadas nas reações de hibridização ou mantidas a $20^{\circ} \mathrm{C}$ para uso posterior.

\subsubsection{Pré-hibridização dos cDNAs}

As membranas de nylon preparadas conforme item 3.3.10.2., contendo os clones de cDNAs desnaturados, provenientes da mini-biblioteca subtraída obtida de plantas induzidas (SF), foram submetidas a uma pré-hibridização a $65^{\circ} \mathrm{C}$ sob agitação suave por $30 \mathrm{~min}$. As membranas foram colocadas em sacos plásticos próprios para hibridização contendo cada um $10 \mathrm{~mL}$ de solução tampão de hibridização "DIG Easy Hyb” (Roche Molecular Biochemicals), pré-aquecida a $65^{\circ} \mathrm{C}$. Os sacos de hibridização foram selados e colocados em banho térmico sob agitação ("Precision Reciprocal Shaking Bath”, Precision Scientific, Winchester, VA). Após o período de préhibridização, as membranas foram utilizadas para a hibridização com as sondas marcadas com digoxigenina. 


\subsubsection{Hibridização dos cDNAs presentes nas membranas com as sondas marcadas}

As sondas marcadas com digoxigenina conforme descrito no item 3.3.10.3., foram previamente desnaturadas antes de serem utilizadas na hibridização. Alíquotas de $10 \mu \mathrm{L}$ de cada sonda de cDNA C-SR ou I-SF marcadas, foram separadamente misturadas com $50 \mu \mathrm{L}$ de água deionizada esterilizada e as misturas foram submetidas à fervura por 5 min, sendo imediatamente resfriadas em gelo. Em seguida, as duas sondas desnaturadas foram misturadas, separadamente, a tubos contendo 3,5 mL de solução de hibridização "DIG Easy Hyb”, pré-aquecidos a $65^{\circ} \mathrm{C}$. Os sacos contendo as membranas foram removidos do banho térmico, após o período de pré-hibridização, e as soluções foram descartadas. Imediatamente, foram adicionados a cada membrana, as soluções de hibridização mantidas a $65^{\circ} \mathrm{C}$ contendo as sondas desnaturadas C-SR ou I-SF. Os sacos foram novamente selados e mantidos em banho térmico a $65^{\circ} \mathrm{C}$ sob agitação suave durante 15-16 horas, para a reação de hibridização.

\subsubsection{Revelação das membranas após a hibridização por quimiluminescência}

Após o período de hibridização, as membranas foram removidas dos sacos plásticos e lavadas duas vezes de 5 min cada, à temperatura ambiente e sob agitação, com solução de baixa estringência, consistindo de tampão SSC 2X contendo 0,1 \% de SDS. Em seguida, foram lavadas duas vezes de 20 min cada, a $65^{\circ} \mathrm{C}$ e sob agitação, com solução de alta estringência pré-aquecida a $65^{\circ} \mathrm{C}$, consistindo de tampão SSC $0,5 \mathrm{X}$ contendo 0,1 \% de SDS. A lavagem, em condições de baixa estringência com solução de alta concentração salina em baixa temperatura, remove as sondas que foram ligadas de forma inespecífica. A lavagem, em condições de alta estringência com solução de baixa concentração salina em temperatura elevada, remove os híbridos de baixa homologia indesejados que podem ter sido formados. As membranas foram, então, transferidas separadamente, para recipientes contendo o tampão de lavagem (tampão ácido maleico 
0,1 M, $\mathrm{NaCl}$ 0,15 M pH 7,5, acrescido de Tween 20 0,3\%) e mantidas por 2 min sob agitação à temperatura ambiente.

Após o descarte do tampão de lavagem, as membranas foram incubadas por 30 min à temperatura ambiente, sob agitação, com solução bloqueadora (solução bloqueadora da Roche diluída 10X com o tampão ácido maleico). Em seguida, a solução bloqueadora foi descartada e as membranas foram incubadas sob agitação à temperatura ambiente durante $30 \mathrm{~min}$, com solução de anticorpo recém preparada (anticorpo antidigoxigenina-AP diluído 1: 10.000, $75 \mathrm{mU} / \mathrm{mL}$, na solução bloqueadora). O anticorpo é um conjugado anti-digoxigenina-fosfatase alcalina que reconhece as moléculas de digoxigenina. Nessa etapa, ocorre a ligação do anticorpo à digoxigenina presente nos híbridos formados, constituídos de cDNAs fixados na membrana e de cDNAs provenientes da sonda.

Após duas lavagens de 15 min cada com o tampão de lavagem, foi realizada a revelação das membranas por quimiluminescência com o substrato CSPD da Roche. As membranas foram equilibradas durante 3 min, no tampão de detecção (Tris-HCl 0,1 M, $\mathrm{NaCl}$ 0,1 M, pH 9,5) e em seguida, colocadas sobre a superfície interna de sacos de hibridização. Foram aplicadas de forma homogênea sobre a superfície de cada membrana, 20 gotas do substrato, cobrindo-as imediatamente com a outra metade dos sacos de hibridização, evitando a formação de bolhas. Após incubação por 5 min à temperatura ambiente, o excesso de líquido foi removido e os sacos foram selados e mantidos por 10 min a $37^{\circ} \mathrm{C}$, para intensificar a reação de luminescência. Nessa etapa, a fosfatase alcalina do conjugado, que foi ligado aos híbridos anteriormente formados, reage com o substrato CSPD no $\mathrm{pH}$ 9,5, formando um composto quimiluminescente.

\subsubsection{Revelação dos filmes de raios $X$}

As membranas, contidas nos sacos de hibridização juntamente com o substrato CSPD, foram expostas a filmes de raios X (BIOMAX ML, Eastman Kodak, Rochester, New York) para detecção do sinal quimiluminescente, utilizando-se pranchas metálicas. Após intervalo de 15 a 25 min de exposição, foi realizada a revelação dos filmes de raios 
X impressionados com o substrato quimiluminescente, utilizando-se soluções fixadora e reveladora com reforçador GBX (Kodak Brasileira, S.J. dos Campos, SP).

Após esse processo, os híbridos formados puderam ser visualizados como manchas escuras formadas nos filmes de raios X. Os híbridos formados com a sonda controle (cDNA C-SR) indicarão os clones de cDNAs presentes na biblioteca subtraída, mas que não são diferencialmente expressos, pois são comuns às plantas controle (Diatchenko et al., 1998 e Wang \& Brown, 1991). Através da comparação das intensidades dos sinais de cada clone nas duas membranas submetidas, separadamente, à hibridização com os cDNAs de plantas induzidas e controle, é possível confirmar aqueles que correspondem a genes induzidos pela aplicação do ASM (Diatchenko et al., 1998 e Wang \& Brown, 1991). Para possibilitar uma avaliação quantitativa, as intensidades dos sinais de hibridização para cada clone foram estimadas através do programa Melanie versão 3 (GeneBio, Genebra, Suíça), o qual utiliza para cálculo diferentes parâmetros, como densidade ótica, área e volume das manchas de hibridização (“spots”). Os volumes das manchas de hibridização, calculados pelo programa, são normalmente utilizados para avaliação das diferenças de intensidade de sinal formados nas membranas, pois são determinados levando-se em consideração, tanto a densidade ótica, como também a área dos “spots” (Wilkins et al., 2001). Os sinais de hibridização formados nas duas membranas com diferença de intensidade igual ou maior que três vezes, utilizando-se o parâmetro do volume das manchas, foram considerados genes expressos diferencialmente nas plantas induzidas. Para a análise e interpretação dos resultados obtidos, baseou-se, também, em informações do manual da Clontech "PCRSelect Differential Screening Kit User Manual” (2001a), referentes aos procedimentos para interpretação dos resultados de hibridização, através da técnica de seleção diferencial. 


\subsection{Isolamento de genes de cafeeiro Híbrido de Timor associados à resistência contra a ferrugem}

Com a finalidade de isolar genes relacionados à resistência vertical em cafeeiro e comparar os mecanismos de resposta de defesa associados à SAR, ativada em cafeeiro suscetível, com a resistência raça-cultivar específica, foram conduzidos experimentos envolvendo as seguintes etapas: inoculação de plantas de café Híbrido de Timor, resistentes à ferrugem, com o patógeno $H$. vastatrix; extração de RNA total a partir de folhas de plantas inoculadas ou não com $H$. vastatrix; síntese de DNA complementar (cDNA) a partir de RNA obtido de plantas inoculadas e controle; hibridização subtrativa por supressão (HSS) para obtenção de uma mini-biblioteca de cDNA enriquecida de genes expressos especificamente na planta inoculada; clonagem e seqüenciamento dos clones obtidos e confirmação da expressão diferencial dos clones, presentes na biblioteca de cDNA subtraída, obtida após a HSS.

\subsubsection{Inoculação das plantas com $H$. vastatrix}

Plantas de café Híbrido de Timor foram inoculadas com uma suspensão aquosa de urediniosporos de $H$. vastatrix na concentração de $2 \mathrm{mg} / \mathrm{mL}$, preparada conforme descrito no item 3.2.2. Os $2^{\text {os }}$ e $3^{\text {os }}$ pares de folhas das plantas foram lavados com água corrente, e em seguida, após a secagem à temperatura ambiente, o patógeno foi aplicado nas superfícies abaxiais das folhas, usando como propelente, nitrogênio gasoso $(0,2$ bars). As plantas controle foram aspergidas com água destilada ao invés do patógeno. As plantas inoculadas e as plantas controle foram colocadas no escuro por $48 \mathrm{~h}$, em umidade relativa de cerca de $85 \%$, a $\pm 24^{\circ} \mathrm{C}$ e, em seguida, mantidas a $\pm 24^{\circ} \mathrm{C}$, em fotoperíodo de $12 \mathrm{~h}$, sob luz fluorescente $\left(7,35 \mathrm{Wm}^{-2}\right)$. Foram utilizados grupos de quatro plantas por tratamento.

As plantas de cafeeiro Híbrido de Timor inoculadas com o patógeno e as plantas controle foram utilizadas para o isolamento de genes relacionados à resistência vertical e, também, para a certificação da resistência contra $H$. vastatrix. 


\subsubsection{Certificação da resistência do cafeeiro Híbrido de Timor contra $H$. vastatrix}

Para certificar a resistência das plantas de café Híbrido de Timor utilizadas nos experimentos, contra $H$. vastatrix, duas plantas inoculadas ou tratadas com água conforme descrito no item 3.4.1., foram mantidas a $\pm 24^{\circ} \mathrm{C}$, em fotoperíodo de $12 \mathrm{~h}$, sob

luz fluorescente $\left(7,35 \mathrm{Wm}^{-2}\right)$. Simultaneamente, plantas de café cV. Mundo Novo, suscetíveis a todas as raças do patógeno foram, também, inoculadas com a mesma suspensão de urediniosporos de $H$. vastatrix $(2 \mathrm{mg} / \mathrm{mL})$, utilizada para a inoculação do Híbrido de Timor, permanecendo nas mesmas condições já descritas (item 3.4.1.). No período de 21-24 dias após a inoculação foi avaliada a presença de sintomas de ferrugem, nas plantas de café Mundo Novo e Híbrido de Timor. Dessa forma, o cafeeiro Mundo Novo foi utilizado como controle da infecção causada por $H$. vastatrix e, a avaliação dos sintomas feita 24 dias após a inoculação foi utilizada para verificar a expressão de incompatibilidade da interação, Híbrido de Timor - H. vastatrix.

\subsubsection{Extração de RNA total}

Plantas de café Híbrido de Timor inoculadas com $H$. vastatrix ou tratadas com água, conforme descrito no item 3.4.1., foram utilizadas para extração de RNA total. Folhas de plantas controle e de plantas inoculadas foram destacadas separadamente das plantas, 72 h após a inoculação com o patógeno, sendo então, lavadas com água corrente, seguida de água deionizada, e secas suavemente com algodão. Amostras de folhas, 100 mg de peso fresco de cada tratamento, foram submetidas à extração de RNA total com $1 \mathrm{~mL}$ do reagente TRIzOL (Life Technologies), seguindo a mesma metodologia descrita para o cv. Mundo Novo (item 3.3.2.).

A concentração de RNA das amostras foi quantificada em espectrofotômetro a 260 nm e o perfil do RNA extraído foi visualizado por eletroforese em gel de agarose 0,8 \%, utilizando o mesmo procedimento adotado para o cafeeiro cv. Mundo Novo. Todas as amostras de RNA foram mantidas em congelador a $-80^{\circ} \mathrm{C}$. 


\subsubsection{Síntese de cDNA}

O DNA complementar foi obtido a partir do RNA total extraído de folhas de cafeeiros Híbrido de Timor inoculados ou não com $H$. vastatrix, conforme descrito no item 3.4.3., utilizando-se o conjunto de síntese "SMART PCR cDNA Synthesis Kit" (Clontech Lab.) e adotando-se a mesma metodologia já descrita para o cafeeiro cv. Mundo Novo (item 3.3.3.). Para a síntese da $1^{\mathrm{a}}$ fita de cDNA, foram utilizadas $1 \mu \mathrm{g}$ de RNA total obtido a partir de folhas de plantas controle ou inoculadas com $H$. vastatrix. A reação de amplificação por LD PCR para a síntese de cDNA dupla fita foi realizada utilizando-se amostras de $1 \mu \mathrm{L}$ de cDNA fita simples obtidos de plantas controle ou inoculadas com o patógeno, previamente diluídas com água deionizada para um volume final de $10 \mu \mathrm{L}$. Os cDNAs de plantas controle e inoculadas obtidos nessa etapa, foram utilizados, em seguida, para a hibridização subtrativa por supressão (HSS).

\subsubsection{Hibridização subtrativa por supressão}

Foi utilizada a HSS para preparar uma mini-biblioteca de cDNA subtraída enriquecida de fragmentos de genes expressos especificamente nas plantas de café Híbrido de Timor inoculadas com $H$. vastatrix e, portanto, induzidos durante a resposta de resistência. A HSS foi realizada com o conjunto para hibridização subtrativa “Clontech PCR-Select cDNA Subtraction Kit” (Clontech Laboratories), a partir dos cDNAs extraídos de folhas de cafeeiros inoculados ou não com $H$. vastatrix, conforme descrito no item 3.4.4. Foi adotado o mesmo procedimento já descrito para o cafeeiro cv. Mundo Novo, realizando todas as etapas (item 3.3.4.).

Foram, também, realizadas, para o cafeeiro Híbrido de Timor, os dois tipos de hibridização subtrativa: forward e reverse. Na hibridização subtrativa forward (SF) foram utilizados como amostra tester, os cDNAs obtidos de plantas inoculadas, os quais foram subtraídos com os cDNAs de plantas controle não tratadas (cDNAs driver), para remover as seqüências comuns. Na hibridização inversa, subtração reverse (SR), os cDNAs das plantas controle foram utilizados como amostra tester, sendo subtraídos com 
os cDNAs obtidos de plantas inoculadas, os quais foram utilizados como driver. O produto da SR foi utilizado, posteriormente, no procedimento da seleção diferencial.

O produto purificado do segundo PCR proveniente da hibridização subtrativa forward (I-SF) foi submetido à clonagem para a obtenção de mini-biblioteca de cDNA de genes obtidos de plantas inoculadas.

\subsubsection{Clonagem e seqüenciamento dos plasmídeos da mini-biblioteca de cDNA de genes obtidos de plantas inoculadas}

O produto purificado do segundo PCR proveniente da HSS forward, contendo os fragmentos de cDNAs de plantas de café inoculadas com H. vastatrix, após subtração com os cDNAs das plantas controle não tratadas (I-SF, item 3.4.5.), foi submetido à clonagem no vetor pGEM-T Easy (Promega). Células eletrocompetentes de E. coli cepa DH $5 \alpha$ foram, então, transformadas com o produto da reação de ligação através de eletroporação. Produziu-se uma mini-biblioteca subtraída de 384 clones de cDNA, enriquecida de fragmentos de genes expressos especificamente nas plantas inoculadas. Os clones foram conservados em glicerol (12,5 \%) na presença de ampicilina (100 $\mu \mathrm{g} / \mathrm{mL}$ ) e mantidos em congelador a $-80^{\circ} \mathrm{C}$, para o armazenamento permanente da biblioteca obtida. Para a clonagem e produção da biblioteca de Híbrido de Timor, foram adotados os mesmos procedimentos já descritos para o cafeeiro cv. Mundo Novo, realizando todas as etapas (itens 3.3.5 e 3.3.6.).

Em seguida, os plasmídeos, extraídos dos 384 clones obtidos através de lise alcalina das células bacterianas, foram seqüenciados no ABI PRISM 377 (Applied Biosystems), utilizando-se os mesmos procedimentos já descritos para as plantas de café cv. Mundo Novo, nos itens 3.3.7. e 3.3.8. Posteriormente, os plasmídeos foram utilizados, também, para confirmar a expressão diferencial dos clones de cDNA da biblioteca de Híbrido de Timor obtida após a HSS, através da técnica de seleção diferencial. 


\subsubsection{Avaliação da função dos genes isolados de cafeeiro Híbrido de Timor inoculado com $H$. vastatrix}

As seqüências dos 384 clones de cDNAs de genes isolados de plantas de café Híbrido de Timor inoculadas com $H$. vastatrix, determinadas conforme mencionado no item 3.4.6., foram comparadas com aquelas presentes em bancos de dados internacionais (NCBI). Para avaliar a função de cada gene de cafeeiro, induzidos durante a resposta de resistência após a inoculação com o patógeno, foi realizada uma comparação com seqüências homólogas presentes no GenBank, utilizando-se o programa BlastX (Altschul et al., 1997). Foi atribuída para cada clone de cDNA analisado, a função associada à seqüência de maior homologia detectada, sendo referida juntamente com a espécie do organismo utilizado para o isolamento do gene e o respectivo número de acesso do GenBank. Homologias com seqüências do GenBank apresentando valores de E maiores do que $10^{-3}$ (1e-03) não foram consideradas significativas.

Foi realizada, também, como já descrito para o cafeeiro cv. Mundo Novo, uma análise de possíveis domínios presentes nas proteínas codificadas pelos genes isolados de Híbrido de Timor, através de busca no banco de dados para domínios conservados, disponível no NCBI (“CD-Search”, NCBI).

\subsubsection{Confirmação por seleção diferencial da expressão de genes ativados em cafeeiro Híbrido de Timor após inoculação com $H$. vastatrix}

Com a finalidade de confirmar se os clones de cDNAs da biblioteca subtraída de cafeeiro Híbrido de Timor obtida após a HSS, continham fragmentos de genes especificamente induzidos nas condições estudadas, realizou-se a seleção diferencial. Os 384 clones da biblioteca de cDNA obtida após a subtração forward (SF) (itens 3.4.5.e 3.4.6.), enriquecida de fragmentos de genes isolados de plantas inoculadas e induzidos durante a resposta de resistência, foram submetidos à seleção diferencial, através de hibridização com sondas de cDNAs de plantas inoculadas e controle, marcadas com

digoxigenina (Roche). A seleção diferencial foi realizada utilizando-se o método de 
arranjo de cDNA ("cDNA array"), de acordo com o mesmo procedimento já descrito para o cafeeiro cv. Mundo Novo, seguindo as mesmas etapas (do item 3.3.10.1. ao 3.3.10.7.). As hibridizações foram, também, realizadas utilizando-se o kit "DIG High Prime DNA Labeling and Detection Starter Kit II” (Roche).

Alíquotas de $2 \mu \mathrm{L}$ de cDNAs previamente desnaturados, de cada clone da biblioteca, foram aplicadas em membranas de nylon positivamente carregadas (Roche). Foram preparadas para cada conjunto de 96 clones duas membranas iguais, que foram posteriormente submetidas à hibridização com dois tipos de sonda: sondas de cDNAs isolados de plantas inoculadas com $H$. vastatrix ou sondas de cDNAs de plantas controle, não tratadas, marcadas com digoxigenina. Foram utilizados como sondas, os produtos de amplificação do segundo PCR provenientes da HSS forward e reverse, após a remoção dos adaptadores e purificação, constituindo-se nas sondas inoculada e controle, respectivamente. A sonda controle consistiu, portanto, de cDNAs de plantas de café não tratadas, após subtração com os cDNAs das plantas inoculadas (C-SR) (produtos da subtração reverse, SR). A sonda inoculada consistiu de cDNAs de plantas de café inoculadas com H. vastatrix, após subtração com os cDNAs das plantas controle não tratadas (I-SF) (produtos da subtração forward, SF). A avaliação dos resultados após a seleção diferencial, para confirmar a expressão de genes especificamente induzidos nas plantas do Híbrido de Timor inoculadas, foi realizada da mesma forma descrita para o cafeeiro cv. Mundo Novo no item 3.3.10.7.

\subsection{Isolamento de cDNAs dos genes codificadores de $\beta$-1,3-glucanase de cafeeiro cv. Mundo Novo e de Híbrido de Timor}

Distintamente de outros métodos de obtenção de genes diferencialmente expressos, a HSS requer a utilização de cDNAs previamente digeridos com enzima de restrição, para que o processo de hibridização seja eficaz. Dessa forma, após a HSS são gerados produtos de amplificação de $100 \mathrm{pb}$ até $1 \mathrm{~kb}$, correspondendo a fragmentos de genes. Portanto, para a obtenção de seqüências completas de genes de interesse detectados nas bibliotecas produzidas, faz-se necessário o uso de uma técnica adicional. 
No presente trabalho, foram produzidas após a HSS (subtração forward, SF), bibliotecas de clones de cDNAs a partir de cafeeiro cv. Mundo Novo, tratado com ASM, e de Híbrido de Timor, inoculado com H. vastatrix, enriquecidas com fragmentos de genes induzidos nas condições estudadas (itens 3.3.6., 3.3.7 e 3.4.6.). As seqüências completas de genes de interesse detectados nas bibliotecas produzidas podem ser obtidas com base nas seqüências parciais determinadas no presente estudo, conforme descrito nos itens 3.3.8. e 3.4.6. A fim de obter as seqüências completas dos genes codificadores de $\beta$-1,3-glucanases de cafeeiro cv. Mundo Novo e de Híbrido de Timor, foram sintetizados primers com base nas seqüências parciais determinadas para os respectivos clones de cDNAs presentes nas bibliotecas subtraídas e utilizados para "caminhar" rumo às extremidades 5' e 3' do RNA mensageiro através da técnica da amplificação rápida das extremidades de cDNAs ("Rapid Amplification of cDNA Ends" - RACE). A técnica RACE foi realizada baseando-se na metodologia desenvolvida por Matz et al. (1999) e nas instruções do manual da Clontech "SMART RACE cDNA Amplification Kit User Manual (2001b). O método RACE utilizado no presente estudo, consiste na amplificação por PCR das extremidades 5' e 3' de cDNAs de genes de interesse, através da utilização de primers específicos. Para as reações de amplificação foram utilizados cDNAs fita simples sintetizados a partir de RNA total, através da tecnologia "SMART", descrita no item 3.3.3. (Chenchik et al., 1998).

\subsubsection{Síntese dos primers para amplificação dos cDNAs dos genes de $\beta-1,3-$ glucanase de cafeeiro cv. Mundo Novo e Híbrido de Timor}

Com a finalidade de obter as seqüências completas dos genes codificadores de $\beta$-1,3-glucanases de cafeeiro cv. Mundo Novo e de Híbrido de Timor, induzidos nas condições estudadas, foram desenhados primers específicos, baseando-se nas seqüências parciais dos respectivos clones de cDNAs das bibliotecas, determinadas conforme descrito nos itens 3.3.8. e 3.4.6. Foram desenhados os seguintes conjuntos de primers: 
a) Mundo Novo:

Primer senso: 5’-GGG ACA GGA ATG CCA ATG TAA-3’

Primer anti-senso: 5’-ATA TAA CCA GGC CGA AGT GGG-3’

Primer interno anti-senso: 5’-TTT ATT TGC GGC AAG TCT TGG-3’

b) Híbrido de Timor:

Primer senso: 5’-ACA TCT TCT GGC ATC ACC ACA-3’

Primer anti-senso: 5'-GGC ATT GTC TAT TGA TGT CGC T-3’

Primer interno senso: 5'-GAT GCT CTC GTG GAT GCA AC-3’

Primer interno anti-senso: 5’-GCC AAC CAG TCT CCG ATA CA-3’

Os primers específicos sintetizados (Life Technologies) foram utilizados nas reações de amplificação por PCR, das extremidades 5' e 3' dos cDNAs dos genes de $\beta$ 1,3-glucanases de cafeeiro cv. Mundo Novo e Híbrido de Timor. Os primers internos senso e anti-senso correspondem às regiões mais internas dos genes.

\subsubsection{Amplificação rápida das extremidades de cDNA - RACE}

A realização da técnica RACE envolveu as seguintes etapas experimentais: síntese das extremidades 5' e 3' dos cDNAs fita simples, a partir de RNAs totais extraídos de cafeeiro cv. Mundo Novo e de Híbrido de Timor, tratados com indutor de resistência ou inoculados com $H$. vastatrix, respectivamente; reações para amplificação das extremidades 5' e 3' dos cDNAs dos genes de $\beta$-1,3-glucanases de cafeeiro cv. Mundo Novo e Híbrido de Timor; clonagem das extremidades 5' e 3' dos cDNAs de $\beta$ 1,3-glucanase nos vetores pCR 4-TOPO ou pGEM-T Easy; digestão dos clones de cDNA codificadores de $\beta$-1,3-glucanase com a enzima EcoRI; seqüenciamento dos clones de cDNAs apresentando as extremidades 5' e 3' dos genes codificadores de $\beta$ 1,3-glucanase de cafeeiro cv. Mundo Novo e Híbrido de Timor. 
Para as reações de síntese e de amplificação das extremidades 5' e 3' dos cDNAs foram empregados os primers e reagentes do conjunto de síntese "SMART PCR cDNA Synthesis Kit” (Clontech) e os primers específicos sintetizados conforme descrito no item 3.5.1.

\subsubsection{Síntese das extremidades 5' e 3’ dos cDNAs provenientes de plantas tratadas com indutor de resistência ou inoculadas com $H$. vastatrix}

Para a síntese das extremidades 5' e 3' dos cDNAs, foram utilizados os RNAs totais extraídos de folhas de plantas de café cv. Mundo Novo, 72 h após o tratamento com ASM (950 $\mu \mathrm{M})$ e de Híbrido de Timor, 72 h após a inoculação com uma suspensão de urediniosporos de $H$. vastatrix $(2 \mathrm{mg} / \mathrm{mL})$. Os RNAs totais foram obtidos conforme já descrito (itens 3.3.2. e 3.4.3.), utilizando-se o reagente TRIzOL.

Para as sínteses da $1^{\text {a }}$ fita de cDNA extremidades 3’, alíquotas de $4 \mu \mathrm{L}$ de RNA total de cafeeiro Híbrido de Timor ou cv. Mundo Novo (cerca de 1,7 a 2,6 $\mu$ g) foram misturadas, separadamente, com $1 \mu \mathrm{L}$ de primer CDS $10 \mu \mathrm{M}$ (equivalente ao 3'-RACE CDS primer A). Após incubação a $70^{\circ} \mathrm{C}$ por 2 min em termociclador, seguida por resfriamento em gelo por $2 \mathrm{~min}$, foram acrescentados a cada mistura, $2 \mu \mathrm{L}$ de tampão- $1^{\text {a }}$ fita $5 \mathrm{X}, 1 \mu \mathrm{L}$ de DTT $20 \mathrm{mM}, 1 \mu \mathrm{L}$ de dNTP 50 X $10 \mathrm{mM}$ e $1 \mu \mathrm{L}$ de transcritase reversa PowerScript. As amostras foram incubadas a $42^{\circ} \mathrm{C}$ por $1 \mathrm{~h}$ e em seguida, diluídas com $40 \mu \mathrm{L}$ de tampão TE. Os cDNAs sintetizados podem ser utilizados para a obtenção das extremidades 3' de todos os genes de cafeeiro induzidos nas condições estudadas.

Para as sínteses da $1^{\text {a }}$ fita de cDNA extremidades 5', alíquotas de $3 \mu \mathrm{L}$ de RNA total de cafeeiro Híbrido de Timor ou cv. Mundo Novo (cerca de 1,3 $\mu$ g a 1,9 $\mu \mathrm{g}$ ) foram misturadas, separadamente, com $1 \mu \mathrm{L}$ de primer anti-senso $10 \mu \mathrm{M}$ especifico para Mundo Novo ou Híbrido de Timor e $1 \mu \mathrm{L}$ do oligonucleotídeo SMART II A $10 \mu \mathrm{M}$. Após incubação a $70^{\circ} \mathrm{C}$ por 2 min em termociclador, seguida por resfriamento em gelo por 2 min, foram acrescentados a cada mistura, $2 \mu \mathrm{L}$ de tampão- $1^{\text {a }}$ fita $5 \mathrm{X}, 1 \mu \mathrm{L}$ de DTT 20 mM, $1 \mu \mathrm{L}$ de dNTP 10 mM 50 X e $1 \mu \mathrm{L}$ de transcritase reversa PowerScript. As 
amostras foram incubadas a $42^{\circ} \mathrm{C}$ por $1 \mathrm{~h}$ e em seguida, diluídas com $40 \mu \mathrm{L}$ de tampão TE. Os cDNAs sintetizados podem ser utilizados apenas para a obtenção das extremidades 5' dos genes de cafeeiro codificadores de $\beta$-1,3-glucanases, induzidos nas condições estudadas.

Em seguida, os cDNAs sintetizados foram submetidos às reações de amplificação por PCR.

\subsubsection{Amplificação das extremidades 5' e 3' dos cDNAs dos genes codificadores de $\beta$-1,3-glucanase pela reação em cadeia da polimerase}

Para amplificação das extremidades 5’ e 3’ dos cDNAs dos genes codificadores de $\beta$-1,3-glucanases, amostras de cDNAs 5' e 3' fita simples, obtidas de cafeeiro Híbrido de Timor ou cv. Mundo Novo (item 3.5.2.1.) foram submetidas à reação de PCR com primers específicos. Em seguida, os produtos da primeira reação de PCR foram submetidos a uma segunda reação de amplificação (Nested PCR), utilizando-se primers específicos internos, senso e anti-senso, correspondentes às regiões mais internas dos genes (nested primers). A realização do Nested PCR teve por finalidade aumentar a especificidade de reação. Os primers foram sintetizados conforme descrito no item 3.5.1.

As primeiras reações de amplificação das extremidades 3’ dos cDNAs foram realizadas misturando-se, separadamente, alíquotas de $1 \mu \mathrm{L}$ de cDNAs 3' fita simples obtidos de cafeeiro Híbrido de Timor ou cv. Mundo Novo, com $1 \mu \mathrm{L}$ de primer senso 10 $\mu \mathrm{M}$ especifico para Mundo Novo ou Híbrido de Timor, $1 \mu \mathrm{L}$ de primer PCR II A 10 $\mu \mathrm{M}, 5 \mu \mathrm{L}$ de tampão PCR $10 \mathrm{X}, 1 \mu \mathrm{L}$ de dNTP $10 \mathrm{mM} 50 \mathrm{X}, 1 \mu \mathrm{L}$ de advantage polimerase mix 50 X e $40 \mu \mathrm{L}$ de água deionizada. A reação de amplificação foi realizada

em termociclador utilizando-se o programa: $95^{\circ} \mathrm{C}$ por $1 \mathrm{~min}, 30$ ciclos de $95^{\circ} \mathrm{C}$ por $5 \mathrm{~s}$, $65^{\circ} \mathrm{C}$ por $5 \mathrm{~s}$ e $68^{\circ} \mathrm{C}$ durante $1,5 \mathrm{~min}$, seguidos de aquecimento a $68^{\circ} \mathrm{C}$ por $5 \mathrm{~min}$.

As primeiras reações de amplificação das extremidades 5’ dos cDNAs foram realizadas adotando-se o mesmo procedimento. Foram utilizados os mesmos componentes nas misturas de reação, com exceção dos cDNAs e primers específicos, 
que foram substituídos por alíquotas de $1 \mu \mathrm{L}$ de cDNAs 5' fita simples obtidos de cafeeiro Híbrido de Timor ou cv. Mundo Novo e $1 \mu \mathrm{L}$ dos respectivos primers específicos anti-senso $10 \mu \mathrm{M}$.

Para as segundas reações de amplificação, foram utilizadas alíquotas de $1 \mu \mathrm{L}$ dos produtos do primeiro PCR, obtidos para cada amostra e previamente diluídos 20 X com água deionizada, $1 \mu \mathrm{L}$ dos respectivos primers internos senso ou anti-senso específicos para Mundo Novo ou Híbrido de Timor, $1 \mu \mathrm{L}$ de primer PCR II A $10 \mu \mathrm{M}, 5$ $\mu \mathrm{L}$ de tampão PCR $10 \mathrm{X}, 1 \mu \mathrm{L}$ de dNTP $10 \mathrm{mM} 50 \mathrm{X}, 1 \mu \mathrm{L}$ de advantage polimerase mix 50 X e $40 \mu \mathrm{L}$ de água deionizada. Para a amplificação das extremidades 3’ dos cDNAs, o nested PCR foi realizado utilizando-se $1 \mu \mathrm{L}$ dos primers internos senso 10 $\mu \mathrm{M}$, enquanto que para as extremidades 5', foram empregados $1 \mu \mathrm{L}$ dos respectivos primers internos anti-senso $10 \mu \mathrm{M}$ específicos para Mundo Novo ou Híbrido de Timor. As nested PCR foram realizadas em termociclador, utilizando-se o mesmo programa descrito para as primeiras reações de amplificação. Para a amplificação da extremidade 3' do gene codificador de $\beta$-1,3-glucanase de cafeeiro cv. Mundo Novo foi realizada apenas a primeira reação de PCR, não sendo necessário o uso de nested PCR. Nesse caso, o primer interno senso especifico para Mundo Novo não foi sintetizado.

Em seguida, os produtos das segundas reações de amplificação foram submetidos à eletroforese em gel de agarose 0,8 \%/EtBr em tampão TAE, aplicando-se alíquotas de $45 \mu \mathrm{L}$ de cada amostra. Após a eletroforese, as bandas de cDNAs foram visualizadas sob luz ultravioleta, com o auxílio de aparelho transiluminador e em seguida, removidas individualmente do gel com lâminas esterilizadas. Os cDNAS foram extraídos dos fragmentos de géis com o kit “QIA quick gel extraction kit” (QIAGEN Sciences, Venlo, Holanda), seguindo-se o protocolo descrito no manual do fabricante. As bandas de cDNAs formadas nos géis após a eletroforese, foram selecionadas para a extração, baseando-se nos tamanhos esperados dos produtos de amplificação para as extremidades 3' e 5' dos cDNAs dos genes codificadores de $\beta$-1,3-glucanases de cafeeiro Híbrido de Timor ou cv. Mundo Novo. 
As amostras de cDNAs extraídas dos géis, foram submetidas à clonagem, para posterior seqüenciamento.

\subsubsection{Clonagem das extremidades 5' e 3' dos cDNAs de $\beta$-1,3-glucanase nos vetores PCR 4-TOPO ou pGEM-T Easy}

Amostras purificadas dos géis de agarose, contendo as extremidades 3' e 5' dos cDNAs dos genes codificadores de $\beta$-1,3-glucanases de cafeeiro Híbrido de Timor ou cv. Mundo Novo, foram submetidas à clonagem nos vetores pCR 4-TOPO (Invitrogen, Life Technologies) ou pGEM-T Easy (Promega). O vetor pCR 4-TOPO, linearizado e ligado covalentemente à enzima topoisomerase, permite a inserção direta de produtos de PCR amplificados pela Taq DNA polimerase, não sendo necessário o uso da enzima ligase. Após a transformação das células de E. coli com o produto da reação de ligação, ocorre o crescimento apenas das células contendo o vetor recombinante, dispensando, portanto, os procedimentos de seleção de colônias bacterianas brancas/azuis.

A ligação dos produtos de PCR ao vetor pCR 4-TOPO foi realizada à temperatura ambiente por $20 \mathrm{~min}$, misturando-se $4 \mu \mathrm{L}$ da amostra de cDNA purificada do gel de agarose, $1 \mu \mathrm{L}$ de solução salina e $1 \mu \mathrm{L}$ do vetor (TOPO TA Cloning Kit, Invitrogen). O produto da reação de ligação com o vetor (6 $\mu \mathrm{L})$ foi precipitado com 24 $\mu \mathrm{L}$ de isopropanol $75 \%$ durante $30 \mathrm{~min}$ a $-80^{\circ} \mathrm{C}$. Após a centrifugação da amostra (20 min, $12.000 \mathrm{~g}, 4^{\circ} \mathrm{C}$ ), o sedimento foi lavado com $150 \mu \mathrm{L}$ de isopropanol $75 \%$ e submetido à secagem a vácuo por 5 min. Em seguida, o sedimento foi dissolvido com 2 $\mu \mathrm{L}$ de água deionizada esterilizada. A ligação dos produtos de PCR ao vetor pGEM-T Easy foi realizada a $4^{\circ} \mathrm{C}$ por 16 horas, misturando-se $7 \mu \mathrm{L}$ de cada amostra de cDNA purificada do gel de agarose, $1 \mu \mathrm{L}$ de tampão de ligação $10 \mathrm{X}, 1 \mu \mathrm{L}$ de pGEM-T Easy e $1 \mu \mathrm{L}$ da enzima T4 DNA ligase (3 unidades/ $\mu \mathrm{L}$ ). Os produtos das reações de ligação foram precipitados com $40 \mu \mathrm{L}$ de isopropanol $75 \%$ e no final do processo, foram ressuspendidos em $2 \mu \mathrm{L}$ de água deionizada. 
Alíquotas de $20 \mu \mathrm{L}$ de células eletrocompetentes de $E$. coli foram transformadas por eletroporação, com os produtos das reações de ligação. Após o choque elétrico, as células foram misturadas com $1 \mathrm{~mL}$ de meio de cultura líquido LB e a suspensão foi mantida sob agitação a $37^{\circ} \mathrm{C}$ durante $50 \mathrm{~min}$. Em seguida a suspensão celular foi plaqueada em meio sólido LB contendo ampicilina (100 mg/mL), utilizandose alíquotas de $200 \mu \mathrm{L}$ de suspensão por placa de Petri. As células de E. coli, transformadas com os produtos das reações de ligação com o vetor pGEM-T Easy, foram adicionadas a placas contendo, também, $5 \mu \mathrm{L}$ de X-Gal e $50 \mu \mathrm{L}$ de IPTG, conforme descrito no item 3.3.6. Após o plaqueamento, as culturas foram mantidas a $37^{\circ} \mathrm{C}$ durante $15 \mathrm{~h}$ para permitir o crescimento das colônias bacterianas. Após esse período, as colônias transformadas foram coletadas com auxílio de palitos esterilizados, sendo transferidas individualmente para tubos contendo $3 \mathrm{~mL}$ de meio LB líquido com ampicilina (100 $\mu \mathrm{g} / \mathrm{mL})$. Foram selecionadas quatro colônias por placa para cada amostra. Em seguida, os tubos foram mantidos a $37^{\circ} \mathrm{C}$ sob agitação em agitador orbital (300 rpm) durante $20 \mathrm{~h}$, para possibilitar o crescimento das células de E. coli transformadas. Após esse período, $750 \mu \mathrm{L}$ das culturas de E. coli de cada tubo foram misturados com $250 \mu \mathrm{L}$ de glicerol $50 \%$, e mantidos em congelador a $-80^{\circ} \mathrm{C}$, para o armazenamento permanente dos clones. O volume restante das culturas de E. coli de cada tubo foram centrifugados por $1 \mathrm{~min}$ a $20^{\circ} \mathrm{C}, 12.000 \mathrm{~g}$, para sedimentação das células bacterianas. Em seguida, o meio de cultura foi descartado e as células sedimentadas foram utilizadas para a extração dos plasmídeos.

Os plasmídeos dos clones contendo as extremidades 3' e 5' dos genes codificadores de $\beta$-1,3-glucanase de cafeeiro Híbrido de Timor e Mundo Novo, foram extraídos das células de E. coli, com o kit da QIAGEN, “QIA prep spin miniprep kit”, seguindo-se o protocolo descrito no manual do fabricante. Os plasmídeos extraídos foram mantidos a $-20^{\circ} \mathrm{C}$ e submetidos a seqüenciamento. 


\subsubsection{Digestão dos clones de cDNA codificadores de $\beta$-1,3-glucanase com a enzima EcoRI}

Os plasmídeos dos clones contendo as extremidades 3' e 5' dos genes codificadores de $\beta$-1,3-glucanase de cafeeiro Híbrido de Timor e Mundo Novo, obtidos conforme descrito no item 3.5.2.3., foram submetidos a digestão com a enzima EcoRI. A digestão enzimática foi realizada para confirmar a presença dos insertos nos vários clones obtidos e para verificar os respectivos tamanhos, antes de ser efetuado o seqüenciamento dos plasmídeos.

Alíquotas de $2 \mu \mathrm{L}$ de cada plasmídeo foram misturadas com $0,25 \mu \mathrm{L}$ de enzima de restrição EcoRI, $1 \mu \mathrm{L}$ de tampão de restrição React $310 \mathrm{X}$ e 6,75 $\mu \mathrm{L}$ de água deionizada. As amostras foram incubadas em termociclador a $37^{\circ} \mathrm{C}$ por $3 \mathrm{~h}$ e, em seguida, foram submetidas à eletroforese em gel de agarose 0,8 \%/EtBr em tampão TAE, aplicando-se todo o volume da reação de digestão para cada amostra.

\subsubsection{Seqüenciamento dos clones de cDNAs apresentando as extremidades 5' e 3' dos genes codificadores de $\beta$-1,3-glucanase}

Os plasmídeos contendo os insertos de cDNA, extraídos de quatro clones obtidos para cada amostra, conforme descrito no item 3.5.2.3., foram seqüenciados em aparelho seqüenciador de DNA, ABI PRISM 377 (Applied Biosystems). Para o seqüenciamento dos cDNAs, apresentando as extremidades 5' e 3' dos genes codificadores de $\beta$-1,3-glucanase de cafeeiro Híbrido de Timor e Mundo Novo, foi utilizado o mesmo método descrito no item 3.3.8. Os clones foram seqüenciados em ambos sentidos, senso e anti-senso, utilizando-se para cada reação, $2 \mu \mathrm{L}$ de cDNA plasmidial de cada amostra e $8 \mu \mathrm{L}$ de "Big Dye Terminator” diluído 4 X no tampão de seqüenciamento contendo 3,3 picomoles de primer universal M13. A reação de seqüenciamento foi realizada em termociclador (PTC-200) utilizando-se o seguinte 
programa: $95^{\circ} \mathrm{C}$ por $60 \mathrm{~s}$ para desnaturação inicial do DNA, seguido de 25 ciclos de $95^{\circ} \mathrm{C}$ por $10 \mathrm{~s} \mathrm{e} 60^{\circ} \mathrm{C}$ durante $4 \mathrm{~min}$. Em seguida, os produtos amplificados da reação de seqüenciamento foram concentrados com isopropanol 75\% conforme descrito no item 3.3.8. Foram realizados três seqüenciamentos para cada clone de cDNA.

Para obter a seqüência completa do gene codificador de $\beta$-1,3-glucanase de cafeeiro cv. Mundo Novo induzido após a aplicação de ASM, foi necessário realizar a sub-clonagem do cDNA contendo a extremidade 5' do gene, após digestão enzimática do clone com HindIII. A reação de digestão enzimática foi realizada em termociclador a $37^{\circ} \mathrm{C}$ por $2 \mathrm{~h}$, misturando-se 8,5 $\mu \mathrm{L}$ de plasmídeo (cDNA 5' clonado no vetor pGEM-T Easy, item 3.5.2.3.), $1 \mu \mathrm{L}$ de tampão de restrição React $210 \mathrm{X}$ e 0,5 $\mu \mathrm{L}$ de HindIII. O produto de digestão enzimática foi submetido à eletroforese em gel de agarose 0,8 \%/EtBr em tampão TAE, aplicando-se todo o volume da reação de digestão. A banda de cDNA, correspondente ao tamanho esperado para o fragmento do gene, foi removida do gel e purificada com o kit “QIA quick gel extraction kit” (QIAGEN). Após a purificação, $50 \mu \mathrm{L}$ do plasmídeo linearizado (vetor pGEM-T Easy contendo o inserto de cDNA) foram misturados com $2 \mu \mathrm{L}$ da enzima T4 DNA ligase (3 unidades/ $\mu \mathrm{L}$ ) em presença de tampão de ligação 10 X. A reação de ligação foi realizada em termociclador a $16^{\circ} \mathrm{C}$ por 16 h. Em seguida, o produto da reação de ligação foi precipitado com isopropanol 75\% e ressuspendido em $2 \mu \mathrm{L}$ de água deionizada. Alíquotas de $20 \mu \mathrm{L}$ de células eletrocompetentes de E. coli foram transformadas por eletroporação com o produto da reação de ligação. As células transformadas foram plaqueadas em meio sólido LB contendo ampicilina $(100 \mu \mathrm{g} / \mathrm{mL})$ e mantidas a $37^{\circ} \mathrm{C}$ por $15 \mathrm{~h}$. Em seguida, os clones foram obtidos conforme procedimento descrito no item 3.5.2.3. Os plasmídeos (glucanase-MN5’-HindIII), extraídos das células de E. coli com o kit “QIA prep spin miniprep kit” (QIAGEN), foram mantidos a $-20^{\circ} \mathrm{C}$ e submetidos a seqüenciamento.

As seqüências obtidas foram comparadas com aquelas depositadas no NCBI, para confirmar a função dos genes isolados de cafeeiro cv. Mundo Novo e Híbrido de Timor, induzidos nas condições estudadas. As seqüências de aminoácidos deduzidas a partir das seqüências de nucleotídeos dos clones de cDNAS, foram analisadas através 
dos programas de previsão PSORT ("Prediction of Protein Sorting Signals and Localization Sites in Amino Acid Sequences”, http://psort.nibb.ac.jp/) (Nakai \& Kanehisa, 1992) e ExPASy (“Expert Protein Analysis System” do "Swiss Institute of Bioinformatics-SIB, http://us.expasy.org/tools/pi_tool.html) (Wilkins et al., 1998), para estimar as propriedades das proteínas codificadas pelos genes. 


\section{RESULTADOS}

\subsection{Determinação da resistência sistêmica adquirida em cafeeiro suscetível cv. Mundo Novo contra H. vastatrix}

\subsubsection{Avaliação da indução de resistência local e sistêmica em cafeeiro cv. Mundo Novo contra $H$. vastatrix}

Os testes biológicos realizados com cafeeiro cv. Mundo Novo revelaram que as plantas tratadas previamente com o composto acibenzolar-S-metil (ASM), na concentração de $200 \mu$ g de i.a./mL (950 $\mu \mathrm{M})$, apresentaram um aumento de resistência contra $H$. vastatrix (Tabela 1, Figura 3). A proteção local e sistêmica contra $H$. vastatrix induzida em plantas de café pelo ASM, foi expressa a partir do primeiro dia após a aplicação do indutor nos terceiros pares de folhas. A proteção pôde ser detectada durante um intervalo de tempo de até 35 dias entre a aplicação do indutor e a inoculação com o patógeno. A proteção local contra a ferrugem, observada um dia após o tratamento com o ASM, atingiu um nível máximo de 87\% entre 7 e 14 dias (Tabela 1). Níveis máximos de proteção sistêmica contra a ferrugem de 53 a 68\% foram observados nos segundos pares de folhas, entre 2 e 21 dias após o tratamento dos terceiros pares de folhas de plantas de café com o indutor (Tabela 1). 
Tabela 1. Indução de resistência local e sistêmica em plantas de café cv. Mundo Novo contra $H$. vastatrix, após diferentes intervalos de tempo do tratamento foliar com acibenzolar-S-metil.

\begin{tabular}{|c|c|c|c|c|c|c|}
\hline \multirow{4}{*}{$\begin{array}{l}\text { Intervalo } \\
\text { de tempo } \\
\text { (dias) }^{1}\end{array}$} & \multicolumn{3}{|c|}{$\begin{array}{l}\text { Proteção local } \\
{ }^{\text {os }} \text { pares de folhas) }\end{array}$} & \multicolumn{3}{|c|}{$\begin{array}{l}\text { Proteção sistêmica } \\
\left(2^{\text {os }} \text { pares de folhas }\right)\end{array}$} \\
\hline & \multirow{2}{*}{\multicolumn{2}{|c|}{$\begin{array}{l}\text { Número médio de } \\
\text { lesões/folha }{ }^{2}\end{array}$}} & \multicolumn{4}{|c|}{ Número médio de } \\
\hline & & & \multirow{2}{*}{$\begin{array}{c}\text { Proteção } \\
\text { (\%) }\end{array}$} & \multicolumn{2}{|c|}{ lesões/folha ${ }^{2}$} & \multirow{2}{*}{$\begin{array}{c}\text { Proteção } \\
(\%)\end{array}$} \\
\hline & Controle & Tratado & & Controle & Tratado & \\
\hline 0 & $111,2 \pm 34,9$ & $122,2 \pm 27,9$ & 0 & $91,7 \pm 10,9$ & $96,0 \pm 17,4$ & 0 \\
\hline 1 & $163,0 \pm 15,5$ & $51,2 \pm 15,3 *$ & 68,6 & $130,0 \pm 7,6$ & $70,5 \pm 10,1^{*}$ & 45,8 \\
\hline 2 & $197,2 \pm 23,3$ & $43,7 \pm 9,9 *$ & 77,8 & $136,1 \pm 4,6$ & $56,6 \pm 17,0^{*}$ & 58,4 \\
\hline 3 & $144,7 \pm 10,5$ & $31,6 \pm 7,8^{*}$ & 78,2 & $117,8 \pm 8,7$ & $56,2 \pm 7,3^{*}$ & 52,3 \\
\hline 7 & $176,2 \pm 12,8$ & $22,3 \pm 7,5^{*}$ & 87,3 & $114,7 \pm 6,7$ & $54,0 \pm 9,6^{*}$ & 52,9 \\
\hline 14 & $130,3 \pm 9,4$ & $18,1 \pm 2,6^{*}$ & 86,1 & $105,7 \pm 5,8$ & $38,8 \pm 11,2^{*}$ & 63,3 \\
\hline 21 & $102,8 \pm 3,7$ & $17,1 \pm 8,7 *$ & 83,4 & $95,6 \pm 10,1$ & $30,6 \pm 5,5^{*}$ & 68,0 \\
\hline 28 & $128,2 \pm 16,1$ & $40,5 \pm 9,2 *$ & 68,4 & $172,6 \pm 17,4$ & $83,4 \pm 4,2 *$ & 51,7 \\
\hline 35 & $150,0 \pm 17,2$ & $51,5 \pm 8,4^{*}$ & 65,7 & $150,1 \pm 6,1$ & $90,1 \pm 11,5^{*}$ & 40,0 \\
\hline
\end{tabular}

${ }^{1}$ Acibenzolar-S-metil (ASM, $200 \mu$ g de i.a./mL) foi aplicado nas superfícies abaxiais dos $3^{\text {os }}$ pares de folhas. Os $2^{\text {os }}$ e $3^{\text {os }}$ pares de folhas foram inoculados com $H$. vastatrix $(2 \mathrm{mg} / \mathrm{ml})$ em determinados intervalos de tempo após o tratamento com o indutor ASM. Plantas controle foram tratadas com água ao invés do indutor. ${ }^{2}$ Médias de dois experimentos \pm erro padrão. Foram utilizados em cada experimento, grupos de 10 plantas para cada tratamento. Médias seguidas por um asterisco diferem significativamente dos respectivos controles ao nível de $5 \%$ de acordo com o teste-t de Student. 


\subsubsection{Determinação das atividades de $\beta$-1,3-glucanases e quitinases em cafeeiro cv. Mundo Novo tratado com indutor de resistência}

O composto acibenzolar-S-metil, na concentração de $200 \mu$ g de i.a./mL, induziu aumento local e sistêmico das atividades de quitinases e $\beta$-1,3-glucanases em folhas de plantas de café tratadas, a partir do primeiro e segundo dia da aplicação do indutor, respectivamente (Tabelas 2 e 3, Figura 3). O aumento local e sistêmico de atividade enzimática em folhas de plantas tratadas com ASM, em relação às plantas controle, foi observado até 35 dias após a aplicação do indutor (Tabelas 2 e 3, Figura 3). As atividades enzimáticas atingiram níveis máximos de aumento nas plantas tratadas em relação ao controle, 7 dias após a aplicação do ASM nos terceiros pares de folhas (Figura 3). Atividades máximas de quitinases e $\beta$-1,3-glucanases foram observadas nos terceiros pares de folhas tratados com o indutor atingindo, respectivamente, níveis cerca de 2 e 2,4 vezes maiores do que aqueles valores detectados para as folhas correspondentes nas plantas controle (Tabelas 2 e 3). No intervalo de tempo de 2 a 21 dias, após o tratamento dos terceiros pares de folhas com o ASM, os segundos pares de folhas não tratados, apresentaram atividades máximas de quitinases e $\beta$-1,3-glucanases, sendo, respectivamente, cerca de 1,7 e 1,9 vezes maiores do que os níveis detectados para as folhas correspondentes nas plantas controle não induzidas (Tabelas 2 e 3). 
Tabela 2. Indução local e sistêmica de quitinases em plantas de café cv. Mundo Novo em diferentes intervalos de tempo após o tratamento das folhas com o indutor acibenzolar-S-metil.

\begin{tabular}{lcccc}
\hline $\begin{array}{l}\text { Intervalo de } \\
\text { tempo }\end{array}$ & \multicolumn{2}{c}{$\begin{array}{c}\text { Atividade de quitinase local } \\
\text { (em dias) } \\
\left({ }^{\text {os }} \text { pares de folhas) }\right.\end{array}$} & $\begin{array}{c}\text { Atividade de quitinase sistêmica } \\
\left({ }^{\circ} \text { pares de folhas) }\right.\end{array}$ \\
\cline { 2 - 5 } & Controle & Tratado $^{3}$ & Controle & Tratado $^{3}$ \\
\hline 0 & $0,175 \pm 0,004$ & $0,179 \pm 0,005$ & $0,176 \pm 0,006$ & $0,182 \pm 0,001$ \\
1 & $0,146 \pm 0,019$ & $0,236 \pm 0,006^{*}$ & $0,181 \pm 0,014$ & $0,212 \pm 0,016$ \\
2 & $0,210 \pm 0,008$ & $0,415 \pm 0,006^{*}$ & $0,204 \pm 0,006$ & $0,389 \pm 0,010^{*}$ \\
3 & $0,209 \pm 0,002$ & $0,385 \pm 0,034^{*}$ & $0,210 \pm 0,010$ & $0,283 \pm 0,005^{*}$ \\
7 & $0,191 \pm 0,018$ & $0,387 \pm 0,029^{*}$ & $0,205 \pm 0,002$ & $0,357 \pm 0,006^{*}$ \\
14 & $0,221 \pm 0,026$ & $0,403 \pm 0,012^{*}$ & $0,217 \pm 0,009$ & $0,367 \pm 0,031^{*}$ \\
21 & $0,209 \pm 0,005$ & $0,353 \pm 0,029^{*}$ & $0,243 \pm 0,001$ & $0,394 \pm 0,023^{*}$ \\
28 & $0,178 \pm 0,012$ & $0,277 \pm 0,018^{*}$ & $0,215 \pm 0,017$ & $0,321 \pm 0,015^{*}$ \\
35 & $0,221 \pm 0,021$ & $0,321 \pm 0,004^{*}$ & $0,199 \pm 0,009$ & $0,293 \pm 0,001^{*}$ \\
\hline
\end{tabular}

${ }^{1}$ Diferentes intervalos de tempo, após o tratamento com acibenzolar-S-metil (ASM, $200 \mu \mathrm{g}$ de i.a./mL), aplicado nas superfícies abaxiais apenas dos $3^{\text {os }}$ pares de folhas. Plantas controle foram tratadas com água ao invés do indutor. ${ }^{2} \mathrm{~A}$ atividade de quitinase foi determinada nos $2^{\text {os }}$ e $3^{\text {os }}$ pares de folhas de plantas de café coletados separadamente em diferentes intervalos de tempo após a indução com ASM. A atividade de quitinase foi expressa pela densidade ótica a $550 \mathrm{~nm}$, determinada através de ensaio enzimático para cada extrato foliar, por 0,2 $\mu \mathrm{g}$ de proteína. Médias de dois experimentos \pm erro padrão. Foram utilizados em cada experimento, grupos de cinco plantas para cada tratamento. Médias seguidas por um asterisco diferem significativamente dos respectivos controles ao nível de 5 \% de acordo com o teste-t de Student. 
Tabela 3. Indução local e sistêmica de $\beta$-1,3-glucanases em plantas de café cv. Mundo Novo em diferentes intervalos de tempo, após o tratamento das folhas com o indutor acibenzolar-S-metil.

\begin{tabular}{|c|c|c|c|c|}
\hline \multirow{2}{*}{$\begin{array}{l}\text { Intervalo } \\
\text { de tempo }{ }^{1} \\
\text { (em dias) }\end{array}$} & \multicolumn{2}{|c|}{$\begin{array}{l}\text { Atividade de } \beta-1,3 \text {-glucanase local }{ }^{2} \\
\text { ( } 3^{\text {os }} \text { pares de folhas) }\end{array}$} & \multicolumn{2}{|c|}{$\begin{array}{l}\text { Atividade de } \beta \text {-1,3-glucanase } \\
\text { sistêmica }^{2}\left(2^{\circ s} \text { pares de folhas) }\right.\end{array}$} \\
\hline & Controle & Tratado $^{3}$ & Controle & Tratado $^{3}$ \\
\hline 0 & $0,125 \pm 0,007$ & $0,121 \pm 0,002$ & $0,146 \pm 0,010$ & $0,129 \pm 0,014$ \\
\hline 1 & $0,174 \pm 0,001$ & $0,252 \pm 0,011^{*}$ & $0,150 \pm 0,024$ & $0,174 \pm 0,011$ \\
\hline 2 & $0,178 \pm 0,027$ & $0,321 \pm 0,007^{*}$ & $0,168 \pm 0,024$ & $0,311 \pm 0,017 *$ \\
\hline 3 & $0,137 \pm 0,007$ & $0,288 \pm 0,022 *$ & $0,126 \pm 0,014$ & $0,229 \pm 0,002 *$ \\
\hline 7 & $0,130 \pm 0,001$ & $0,309 \pm 0,014 *$ & $0,140 \pm 0,021$ & $0,277 \pm 0,013^{*}$ \\
\hline 14 & $0,166 \pm 0,009$ & $0,397 \pm 0,016^{*}$ & $0,175 \pm 0,001$ & $0,335 \pm 0,033^{*}$ \\
\hline 21 & $0,177 \pm 0,008$ & $0,382 \pm 0,026^{*}$ & $0,194 \pm 0,014$ & $0,384 \pm 0,020^{*}$ \\
\hline 28 & $0,173 \pm 0,010$ & $0,276 \pm 0,004^{*}$ & $0,169 \pm 0,011$ & $0,257 \pm 0,013^{*}$ \\
\hline 35 & $0,148 \pm 0,006$ & $0,237 \pm 0,018^{*}$ & $0,151 \pm 0,012$ & $0,237 \pm 0,011^{*}$ \\
\hline
\end{tabular}

${ }^{1}$ Diferentes intervalos de tempo, após o tratamento com acibenzolar-S-metil (ASM, $200 \mu \mathrm{g}$ de i.a./mL), aplicado nas superfícies abaxiais apenas dos $3^{\text {os }}$ pares de folhas. Plantas controle foram tratadas com água ao invés do indutor. ${ }^{2} \mathrm{~A}$ atividade de $\beta$-1,3-glucanase foi determinada nos $2^{\text {os }}$ e $3^{\text {os }}$ pares de folhas de plantas de café coletados separadamente em diferentes intervalos de tempo após a indução com ASM. A atividade de $\beta$-1,3-glucanase foi expressa pela densidade ótica a $600 \mathrm{~nm}$, determinada através de ensaio enzimático para cada extrato foliar, por $20 \mu \mathrm{g}$ de proteína. ${ }^{3}$ Médias de dois experimentos \pm erro padrão. Foram utilizados em cada experimento, grupos de cinco plantas para cada tratamento. Médias seguidas por um asterisco diferem significativamente dos respectivos controles ao nível de $5 \%$ de acordo com o teste-t de Student. 


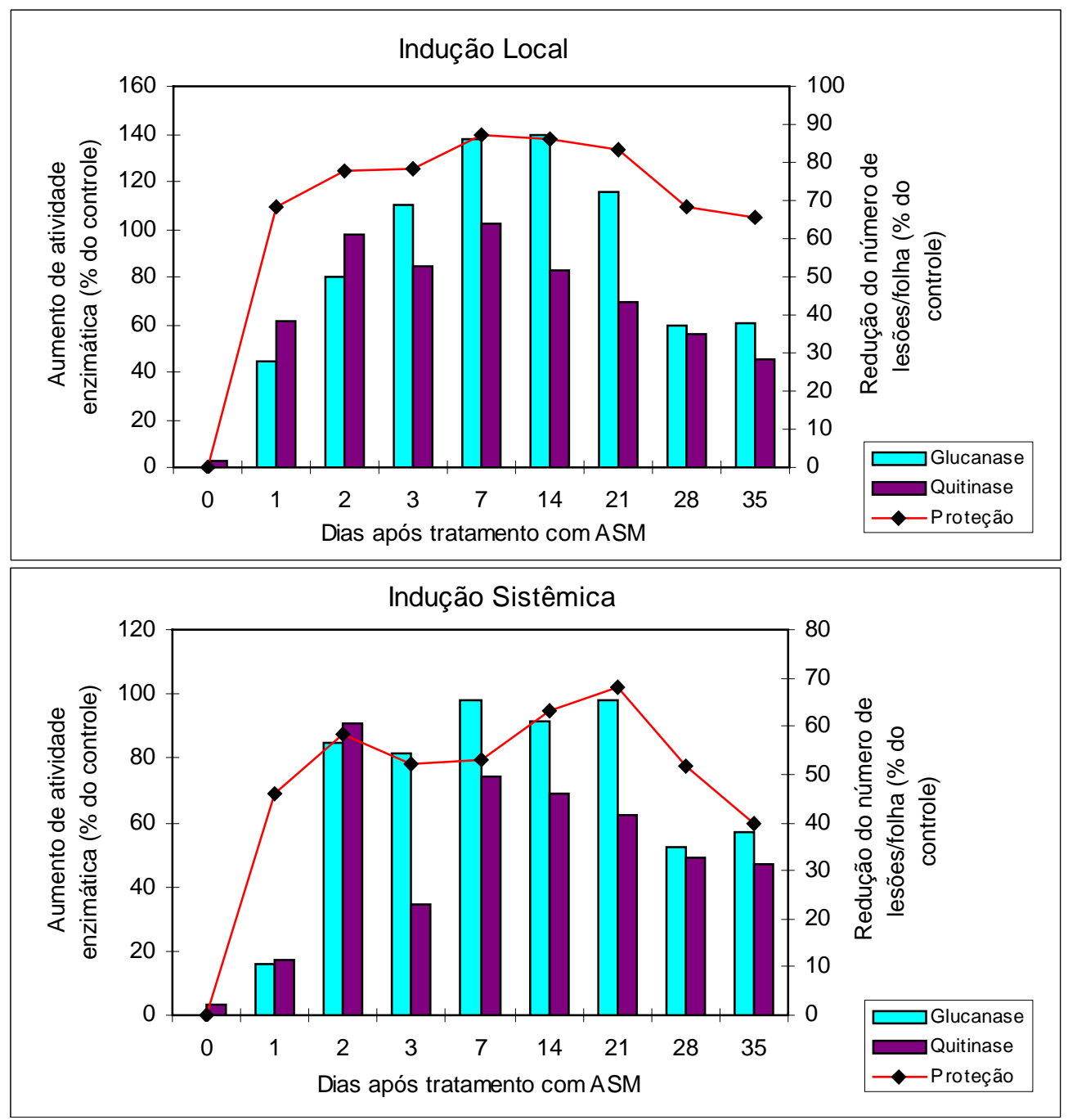

Figura 3 - Indução local e sistêmica de quitinases e $\beta$-1,3-glucanases em folhas de cafeeiros suscetíveis cv. Mundo Novo, protegidos contra $H$. vastatrix por acibenzolar-S-metil (ASM).

O ASM (200 $\mu$ g de i.a./mL) foi aplicado nos $3^{\text {os }}$ pares de folhas de plantas de café. Após diferentes intervalos de tempo, os $2^{\text {os }}$ e $3^{\text {os }}$ pares de folhas foram inoculados com H. vastatrix $(2 \mathrm{mg} / \mathrm{ml})$ para avaliação da indução de resistência ou utilizados para determinação das atividades de quitinases e de $\beta$-1,3-glucanases. Plantas controle foram tratadas com água ao invés do indutor. Indução local: as atividades enzimáticas (aumento de atividade em relação ao controle) e a indução de resistência (redução do número de lesões por folha nas plantas tratadas em relação ao controle) foram determinadas nos $3^{\text {os }}$ pares de folhas. Indução sistêmica: determinações realizadas nos $2^{\text {os }}$ pares de folhas. Médias de dois experimentos, utilizando-se grupos de15 plantas para cada tratamento. 


\subsection{Isolamento de genes de cafeeiro cv. Mundo Novo, associados à resistência sistêmica adquirida}

\subsubsection{Extração de RNA total de cafeeiro cv. Mundo Novo a partir de plantas controle ou tratadas com indutor de resistência}

Os RNAs totais foram eficientemente extraídos de plantas de café cv. Mundo Novo controle ou tratadas com o indutor ASM $(950 \mu \mathrm{M})$, através da utilização do reagente TRIzOL, como mostra a eletroforese em gel de agarose representada na Figura 4. Foi possível verificar a presença no gel de duas bandas mais intensas, características de RNAs ribossômicos de células vegetais, 25S e 17S. As amostras provenientes de plantas controle, tratadas com água ao invés do indutor de resistência, apresentaram concentrações de RNA de 250 a $430 \mu \mathrm{g} / \mathrm{mL}$. As amostras de RNA, extraídos de tecidos foliares de plantas 72 h após o tratamento com o ASM, apresentaram concentrações de 520 a $1.060 \mu \mathrm{g} / \mathrm{mL}$.

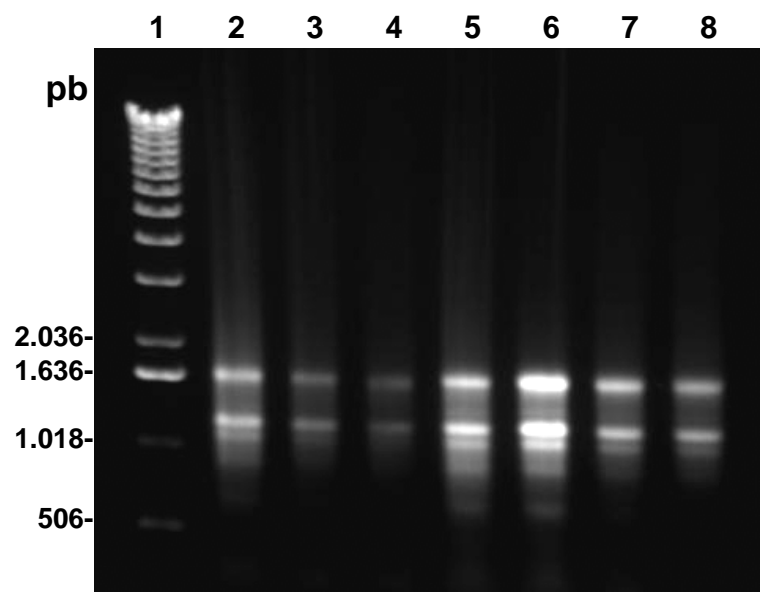

Figura 4 - Eletroforese em gel de agarose (0,8 \%) de RNA total extraído de cafeeiro cv. Mundo Novo antes e após o tratamento com acibenzolar-S-metil (ASM).

1: Padrão de DNA de 1kb ladder; 2 a 4: RNAs totais extraídos de folhas de plantas tratadas com água (controle, C), C-2 430 $\mu \mathrm{g} / \mathrm{mL}$, C-3 e C-4 $290 \mu \mathrm{g} / \mathrm{mL}$; 5 a 8: RNAs totais de cafeeiro tratado com ASM $(950 \mu \mathrm{M})$ (induzido, I), I-5 $920 \mu \mathrm{g} / \mathrm{mL}$, I-6 1.060 $\mu \mathrm{g} / \mathrm{mL}, \mathrm{I}-7640 \mu \mathrm{g} / \mathrm{mL}$, I-8 $520 \mu \mathrm{g} / \mathrm{mL}$. pb: pares de base. Foram aplicados no gel 5 $\mu \mathrm{L}$ de cada amostra de RNA. 


\subsubsection{Síntese de cDNA a partir de RNA extraído de plantas de café Mundo Novo controle ou tratadas com indutor de resistência}

O perfil eletroforético dos cDNAs sintetizados a partir dos RNAs totais, extraídos de plantas de café cv. Mundo Novo controle ou tratadas com o indutor ASM (950 $\mu \mathrm{M}$ ), pode ser visualizado na Figura 5. Através de eletroforese em gel de agarose, foi possível verificar a presença de bandas de cDNAs dupla fita sintetizados após a realização de LD PCR, tanto nas amostras provenientes de plantas controle, tratadas com água ao invés do indutor de resistência, como naquelas provenientes de plantas induzidas. Puderam ser visualizadas, também, bandas de cDNAs nas amostras, após a purificação dos produtos de LD PCR em colunas CHROMA SPIN-1000. Os resultados indicaram que o DNA complementar pôde ser sintetizado a partir de RNA total extraído de plantas de café, através da metodologia utilizada.



Figura 5 - Eletroforese em gel de agarose $(1,2 \%)$ de cDNA sintetizado a partir de RNA total extraído de cafeeiro cv. Mundo Novo antes e após o tratamento das plantas com acibenzolar-S-metil (ASM).

1: Padrão de DNA de 1Kb ladder; 2 a 4: cDNAs de plantas controle, tratadas com água, 2-produto bruto de LD PCR, 3 e 4- cDNAs dupla fita após purificação em colunas CHROMA SPIN-1000; 5 a 8: cDNAs de plantas tratadas com ASM (950 $\mu \mathrm{M}), 5$ e 6- produtos brutos de LD PCR, 7 e 8 cDNAs dupla fita após purificação em colunas CHROMA SPIN-1000. pb: pares de base. Foram aplicados no gel $3 \mu \mathrm{L}$ de cada amostra de cDNA bruto, obtido após o LD PCR e $10 \mu \mathrm{L}$ das amostras de cDNA purificadas. 


\subsubsection{Isolamento por hibridização subtrativa por supressão de genes de cafeeiro Mundo Novo tratado com indutor de resistência}

Os cDNAs provenientes de plantas de café cv. Mundo Novo, tratadas com água ou com o indutor ASM (950 $\mu \mathrm{M})$, utilizados para a hibridização subtrativa por supressão (HSS), apresentaram concentrações iguais a $433 \mathrm{ng} / \mu \mathrm{L}$ e $400 \mathrm{ng} / \mu \mathrm{L}$, respectivamente, após digestão com Rsa I e purificação. As amostras de plantas controle ou tratadas com ASM, com volumes de 6,7 $\mu \mathrm{L}$ cada, apresentaram concentrações totais de cDNA iguais a 2,9 e 2,7 $\mu$ g, respectivamente. Os valores obtidos indicaram um rendimento dentro da faixa estabelecida para a metodologia empregada, que prevê a obtenção de 2 a $6 \mu$ g de cDNA purificados, sintetizados no final do processo ("SMART PCR cDNA Synthesis Kit User Manual”, 2000).

Segundo a metodologia de HSS empregada no presente estudo, em hibridizações bem sucedidas, o padrão eletroforético dos cDNAs presentes nas amostras obtidas após a subtração, deve ser distinto do perfil de bandas observado nas amostras não subtraídas (“CLONTECH PCR-Select cDNA Subtraction Kit User Manual”, 2000a). Os perfis eletroforéticos dos produtos das reações de PCR realizadas após a HSS forward (SF) e reverse (SR), enriquecidos, respectivamente, de fragmentos de cDNAs provenientes de plantas de café tratadas com o ASM (I-SF) ou com água (C-SR), podem ser visualizados na Figura 6. A eletroforese em gel de agarose revelou padrões distintos de bandas para as amostras de cDNAs subtraídas, provenientes da SF ou SR, em relação aos respectivos controles não subtraídos (controle tester não-subtraído, controle driver não-subtraído), indicando que as hibridizações subtrativas foram realizadas de forma eficiente. Puderam ser visualizadas, também, bandas mais intensas na amostra I-SF, contendo cDNAs de plantas de café induzidas à resistência com ASM, após subtração com os cDNAs das plantas controle não tratadas, quando comparadas com aquelas presentes no produto da subtração reverse (amostra C-SR). O número menor de bandas observado na amostra C-SR, que contém os cDNAs de plantas de café não tratadas, após subtração com os cDNAs das plantas induzidas à resistência, sugere que o tratamento com ASM induziu a expressão de genes em cafeeiro cv. Mundo Novo (Figura 6). 




Figura 6 - Eletroforese em gel de agarose (1,5 \%) de cDNAs obtidos após hibridização subtrativa por supressão (HSS) e amplificação por PCR, provenientes de plantas de café cv. Mundo Novo, tratadas com o ASM ou com água.

1: Padrão de DNA de $1 \mathrm{~Kb}$ ladder; 2 a 5: produtos do segundo PCR da HSS. 2cDNAs de plantas tratadas com ASM, após subtração com cDNAs de plantas controle (I-SF); 3- cDNAs de plantas induzidas não-subtraídas (controle tester não-subtraído); 4- cDNAs de plantas tratadas com água, após subtração com os cDNAs das plantas induzidas (C-SR); 5- cDNAs de plantas controle não-subtraídas (controle driver nãosubtraído). pb: pares de base. Foram aplicados no gel $8 \mu \mathrm{L}$ de cada amostra.

Através de eletroforese em gel de agarose da amostra I-SF purificada, representada na Figura 7, foi possível verificar que na subtração forward são gerados produtos de amplificação de 100 pb até $1 \mathrm{~kb}$, correspondendo a fragmentos de genes com um tamanho médio de 500 pb. Foi constatado que após a clonagem da amostra ISF, foi produzida uma biblioteca de cDNA subtraída enriquecida de genes induzidos pelo ASM em cafeeiro e constituída por 384 clones portando fragmentos de genes de 100 pb até $1 \mathrm{~kb}$, sendo a maioria de tamanho na faixa de 200 a 600 pb. 


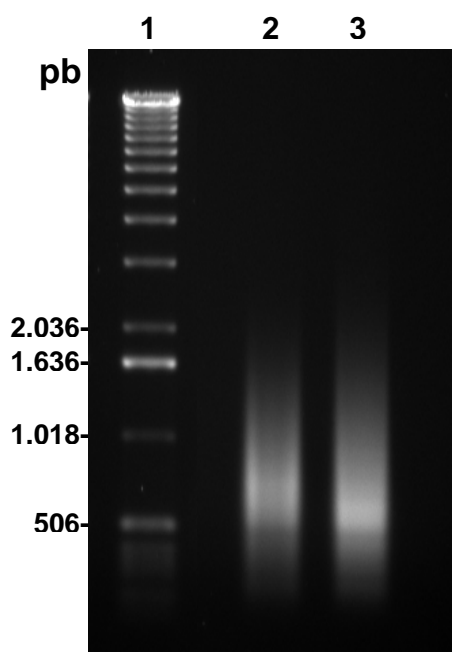

Figura 7 - Eletroforese em gel de agarose (1,5 \%) do produto do segundo PCR da hibridização subtrativa por supressão (HSS), antes e após purificação, proveniente de plantas de café cv. Mundo Novo, tratadas com o ASM.

1: Padrão de DNA de 1Kb ladder; 2: Produto do segundo PCR da HSS forward, antes da purificação. Fragmentos de cDNAs de plantas tratadas com ASM, após subtração com os cDNAs de plantas controle tratadas com água (I-SF); 3- I-SF purificado. Foram aplicados no gel $8 \mu \mathrm{L}$ de cada amostra.

\subsubsection{Seqüenciamento e avaliação da função de genes isolados de cafeeiro Mundo Novo tratado com indutor de resistência}

As seqüências de 384 clones de cDNAs geradas após a HSS, comparadas com aquelas depositadas no NCBI utilizando-se o programa BlastX, permitiram identificar, em cafeeiros cv. Mundo Novo induzidos à resistência com o ASM, sete grupos de genes apresentando funções relacionadas à defesa de plantas contra fitopatógenos (Tabelas 4, 5, 6, 7, 8, 9 e 10) e um grupo associado à manutenção celular e desenvolvimento vegetal (Tabela 11). Foi verificado, também, que 38 clones de cafeeiro apresentaram similaridade com seqüências depositadas no banco de dados, designadas por proteínas hipotéticas, proteínas desconhecidas ou proteínas expressas, que correspondem a genes com funções desconhecidas, sendo a maioria isolada de $A$. thaliana ou de $O$. sativa. Foi constatado, ainda, que 180 clones da mini-biblioteca de cDNAs de genes obtidos de 
plantas de café induzidas não apresentaram similaridade com seqüências do GenBank ou apresentaram homologias com valores de $\mathrm{E}$ maiores do que $10^{-3}$ (1e-03), não sendo, portanto, consideradas significativas.

Nas Tabelas 4, 5, 6, 7, 8, 9 e 10 estão relacionadas as funções encontradas para os genes isolados de cafeeiro após tratamento com ASM, envolvidos em diversos processos relacionados à resistência de plantas contra fitopatógenos como: formação de espécies de oxigênio reativas (ROS), resposta de hipersensibilidade, apoptose, síntese e transporte de metabólitos antimicrobianos, percepção e transdução de sinal que leva à ativação do estado de resistência, síntese de proteínas relacionadas à patogênese, metabolismo de lipídeos e degradação controlada de proteínas. Os clones de cDNA de cafeeiro foram relacionados em sete grupos, de acordo com as categorias funcionais associadas à defesa vegetal, encontradas para cada gene.

No primeiro grupo de genes relacionados à defesa vegetal, identificados em cafeeiros após tratamento com ASM, se encontram aqueles implicados no estresse oxidativo, na resposta de hipersensibilidade ou na morte celular programada (apoptose), como pode ser observado na Tabela 4. Quanto aos genes relacionados ao estresse oxidativo, foram isolados dois clones codificadores da enzima superóxido dismutase cobre/zinco (SOD) envolvida na produção de ROS e um total de quatro clones de enzimas antioxidantes, como a catalase, glutationa-S-transferase (GST) e ascorbato peroxidase, envolvidas nos mecanismos específicos de proteção celular. Foi verificada, também, a presença de três clones codificadores de cisteínas proteinases, implicadas, como mediadoras, na morte celular induzida por patógenos ou por estresse oxidativo em tecidos vegetais. As cisteínas proteinases de cafeeiro cv. Mundo Novo apresentaram similaridade com as tiol-proteases da família papaína. A análise através do programa CD-Search do NCBI revelou, que as proteínas codificadas pelos genes isolados de cafeeiro, apresentaram, também, os domínios conservados característicos para ascorbato peroxidase, catalases, cisteína proteinases e SOD, com exceção do clone MN-HSS2-E04 codificador da GST.

Foi detectado em cafeeiros tratados com ASM, um segundo grupo de genes codificadores de compostos antimicrobianos, como a proteína principal do látex, 
quitinases, $\beta$-1,3-glucanase, inibidores de cisteína proteinases (cistatinas) e protease aspártica (Tabela 5). Nesse grupo foram encontrados genes codificadores de proteínas relacionadas à patogênese, incluindo as enzimas quitinases e $\beta$-1,3-glucanase e os inibidores de cisteína proteinases. Como pode ser observado na Tabela 5, foram isolados em cafeeiro cinco genes codificadores de quitinases, sendo que os clones MN-HSS4E01 e MN-HSS3-B12 representando, provavelmente, proteínas básicas, apresentaram os domínios conservados de quitinases da classe I (pfam00182), pertencentes às glicosil hidrolases da família 19, além de domínios adicionais de quitinases (KOG4742; COG3179). Por outro lado, os clones MN-HSS1-A01 e MN-HSS1-H05 representam proteínas acídicas e apresentaram domínio igual característico de quitinases (KOG4701), sendo que o clone MN-HSS1-A01, que apresentou similaridade com quitinase de Vigna angularis, possui um domínio adicional de glicosil hidrolases da família 18 (pfam00704). Além disso, o clone MN-HSS1-H05 apresentou similaridade com uma quitinase acídica da classe III isolada de soja com atividade adicional de lisozima (Tabela 5). A seqüência determinada para o clone MN-HSS1-F10 apresentou, também, maior similaridade com uma quitinase da classe III isolada de bulbo de tulipa. Os dois clones de cafeeiro, codificadores de inibidores de proteinase, apresentaram, cada um, três domínios de cistatina, enquanto que aqueles codificadores da proteína principal do látex (“major latex protein”, MLP), possuem o domínio característico da proteína relacionada à patogênese, “Bet v 1”, pertencente à família PR-10 (pfam00407), que podem apresentar atividade de ribonuclease (CD-Search, NCBI). Esses resultados sugerem que os clones MN-HSS2-F09 e G10, codificam uma proteína MLP antimicrobiana, pertencente à família de proteínas relacionadas à patogênese PR-10. Para a $\beta$-1,3-glucanase codificada pelo clone de cafeeiro cv. Mundo Novo, MN-HSS2B03, foram encontrados um domínio de $\beta$-1,3-glucanase (COG5309) e um característico de glicosil hidrolases da família 17 (pfam00332). A partir da seqüência de nucleotídeos determinada para o clone de cDNA, MN-HSS2-B03, foi possível desenhar os primers específicos senso e anti-senso para a obtenção da seqüência completa do gene de cafeeiro cv. Mundo Novo codificador de $\beta$-1,3-glucanase, induzido nas condições estudadas. 
Tabela 4. Genes de cafeeiro Mundo Novo tratado com ASM, envolvidos no estresse oxidativo, resposta de hipersensibilidade e/ou apoptose.

\begin{tabular}{|c|c|c|c|}
\hline Função ( $n^{\circ}$ de acesso) ${ }^{1}$ & Clone $^{2}$ & Valor de $\mathrm{E}^{3}$ & $\begin{array}{l}\text { Expressão } \\
\text { diferencial do } \\
\text { gene }^{4}\end{array}$ \\
\hline $\begin{array}{l}\text { Ascorbato peroxidase peroxissomal } \\
\text { [Cucurbita cv. Kurokawa Amakuri] } \\
\text { BAB64351 }\end{array}$ & MN-HSS3-B11 & $1 e-30$ & + \\
\hline Catalase [Gossypium hisutum] S10395 & MN-HSS2-H06 & $4 e-95$ & + \\
\hline $\begin{array}{l}\text { Catalase, isoenzima } 3 \text { [Nicotiana } \\
\text { plumbaginifolia] P49317 }\end{array}$ & MN-HSS1-F07 & $1 e-28$ & + \\
\hline $\begin{array}{l}\text { Cisteína proteinase [Arabidopsis } \\
\text { thaliana] NP567489 }\end{array}$ & MN-HSS4-C08 & $2 \mathrm{e}-21$ & + \\
\hline $\begin{array}{l}\text { Cisteína proteinase (precursor) } \\
\text { [Ipomoea batatas] AAQ81938 }\end{array}$ & MN-HSS3-G07 & 2e-05 & + \\
\hline $\begin{array}{l}\text { Cisteína proteinase (precursor) } \\
\text { [Phaseolus vulgaris] T12041 }\end{array}$ & MN-HSS2-A11 & $4 e-29$ & + \\
\hline $\begin{array}{l}\text { Glutationa-S-transferase (GST) } \\
\text { [Vitis vinifera] AAN85827 }\end{array}$ & MN-HSS2-E04 & 3e-08 & + \\
\hline $\begin{array}{l}\text { Superóxido dismutase cobre/zinco } \\
\text { [Populus tremula x Populus } \\
\text { tremuloides] CAC33845 }\end{array}$ & MN-HSS3-D05 & $9 e-26$ & + \\
\hline $\begin{array}{l}\text { Superóxido dismutase cobre/zinco } \\
\text { [Sandersonia aurantiaca] AAL85888 }\end{array}$ & MN-HSS1-A05 & 2e-15 & + \\
\hline
\end{tabular}

${ }^{1}$ A função de cada gene foi detectada por comparação com seqüências homólogas presentes no NCBI, utilizando-se o programa BlastX. A função associada à seqüência de maior homologia detectada para cada clone de cDNA de cafeeiro, foi relacionada juntamente com a respectiva origem (espécie do organismo e número de acesso do GenBank). ${ }^{2}$ Genes isolados por hibridização subtrativa por supressão, a partir de mRNAs de cafeeiro cv. Mundo Novo tratado com ASM. ${ }^{3} \mathrm{O}$ valor de E foi utilizado para indicar a significância da similaridade de seqüência encontrada para cada gene. ${ }^{4}$ A confirmação da expressão de cada gene isolado de planta tratada foi determinada utilizando-se a técnica da seleção diferencial. +: gene induzido; -: gene não induzido. 
Tabela 5. Genes isolados de cafeeiro Mundo Novo tratado com ASM, codificadores de compostos antimicrobianos.

\begin{tabular}{|c|c|c|c|}
\hline Função (nº de acesso) ${ }^{1}$ & Clone $^{2}$ & Valor de $\mathrm{E}^{3}$ & $\begin{array}{l}\text { Expressão } \\
\text { diferencial do } \\
\text { gene }^{4}\end{array}$ \\
\hline $\begin{array}{l}\text { Aspártico protease (tipo nucelina) } \\
\text { [Arabidopsis thaliana] NP850981 }\end{array}$ & MN-HSS4-G06 & 3e-26 & + \\
\hline $\begin{array}{l}\beta-1,3-\text { Glucanase (glicosil hidrolase } \\
\text { família 17) [Arabidopsis thaliana] } \\
\text { NP197323 }\end{array}$ & MN-HSS2-B03 & $6 e-43$ & + \\
\hline $\begin{array}{l}\text { Inibidor de cisteína proteinase (tipo } \\
\text { cistatina) [Arabidopsis thaliana] } \\
\text { NP193383 }\end{array}$ & MN-HSS2-B02 & 3e-06 & + \\
\hline $\begin{array}{l}\text { Inibidor de cisteína proteinase } \\
\text { (proteína tipo cistatina) [Citrus } \\
\text { paradisi] AAG38521 }\end{array}$ & MN-HSS3-H07 & 3e-05 & + \\
\hline $\begin{array}{l}\text { Proteína principal do látex [Vitis } \\
\text { vinifera] CAB85634 }\end{array}$ & $\begin{array}{l}\text { MN-HSS2-F09 e } \\
\text { G10 }\end{array}$ & $7 e-16$ & + \\
\hline $\begin{array}{l}\text { Quitinase [Castanea sativa] } \\
\text { AAB01895 }\end{array}$ & MN-HSS3-B12 & $1 e-41$ & - \\
\hline $\begin{array}{l}\text { Quitinase-1 [Tulipa bakeri] } \\
\text { BAA88408 }\end{array}$ & MN-HSS1-F10 & $3 e-44$ & + \\
\hline $\begin{array}{l}\text { Quitinase acídica classe III [Glycine } \\
\text { max] T05187 }\end{array}$ & MN-HSS1-H05 & $4 e-09$ & + \\
\hline $\begin{array}{l}\text { Quitinase acídica [Vigna angularis] } \\
\text { P29024 }\end{array}$ & MN-HSS1-A01 & $5 e-42$ & + \\
\hline $\begin{array}{l}\text { Quitinase básica [Vitis vinifera] } \\
\text { P51613 }\end{array}$ & MN-HSS4-E01 & 3e-42 & + \\
\hline
\end{tabular}

\footnotetext{
${ }^{1}$ A função de cada gene foi detectada por comparação com seqüências homólogas presentes no NCBI, utilizando-se o programa BlastX. A função associada à seqüência de maior homologia detectada para cada clone de cDNA de cafeeiro, foi relacionada juntamente com a respectiva origem (espécie do organismo e número de acesso do GenBank). ${ }^{2}$ Genes isolados por hibridização subtrativa por supressão, a partir de mRNAs de cafeeiro Mundo Novo tratado com ASM. ${ }^{3} \mathrm{O}$ valor de E foi utilizado para indicar a significância da similaridade de seqüência encontrada para cada gene. ${ }^{4}$ A confirmação da expressão de cada gene isolado de planta tratada foi determinada utilizando-se a técnica da seleção diferencial. +: gene induzido; -: gene não induzido.
} 
Como pode ser observado na Tabela 6, o terceiro grupo de genes relacionado à defesa vegetal isolado de cafeeiro tratado com ASM, está envolvido na síntese e transporte de metabólitos antimicrobianos. Foram isolados três clones de genes codificadores de cinamil álcool desidrogenase (CAD), uma enzima que catalisa a etapa específica para a produção dos monômeros de lignina, os álcoois derivados dos ácidos cinâmicos (monolignóis) provenientes da via dos fenilpropanóides. Além da CAD, puderam ser isolados outros genes implicados na síntese de metabólitos secundários antimicrobianos, como aqueles que apresentaram similaridade com a chalcona sintase e a flavanona-3-hidroxilase, enzimas envolvidas no metabolismo de flavonóides. Quanto ao transporte de metabólitos antimicrobianos, foi identificado um clone de cDNA codificador da proteína transportadora ABC, envolvida na secreção de terpenos antifúngicos ou no transporte de outros compostos tóxicos do metabolismo secundário. A análise através do programa CD-Search do NCBI revelou, que as proteínas codificadas pelos genes isolados de cafeeiro, clones MN-HSS4-B06 e MN-HSS2-G04, apresentaram, também, os domínios conservados de chalcona sintase e da superfamília de transportadores $\mathrm{ABC}$, respectivamente. Os três clones de cDNA de genes codificadores de CAD apresentaram domínios de álcool desidrogenase classe $\mathrm{V}$, enquanto que aqueles codificadores de flavanona-3-hidroxilase, possuem domínios de oxidoredutases e de oxigenases. 
Tabela 6. Genes de cafeeiro Mundo Novo tratado com ASM, envolvidos na síntese de fitoalexinas, fenóis, flavonóides e/ou lignina e no transporte de compostos secundários antimicrobianos.

\begin{tabular}{lccc}
\hline \multicolumn{1}{c}{ Função (n ${ }^{\circ}$ de acesso) ${ }^{1}$} & Clone $^{2}$ & Valor de E $^{3}$ & $\begin{array}{c}\text { Expressão } \\
\text { diferencial do } \\
\text { gene }^{4}\end{array}$ \\
\hline $\begin{array}{l}\text { Chalcona sintase 2 [Camellia } \\
\text { sinensis] P48387 }\end{array}$ & MN-HSS4-B06 & $6 \mathrm{e}-32$ & + \\
$\begin{array}{l}\text { Cinamil álcool desidrogenase } \\
\text { (CAD) [Aralia cordata] P42495 }\end{array}$ & MN-HSS2-D02 & $7 \mathrm{e}-92$ & + \\
$\begin{array}{l}\text { Cinamil álcool desidrogenase } \\
\text { (CAD) [Lotus corniculatus] }\end{array}$ & MN-HSS3-E12, & 1e-05 & + \\
$\begin{array}{l}\text { AAK61495 } \\
\text { Flavanona-3-hidroxilase } \\
\text { [Arabidopsis thaliana] NP197841 }\end{array}$ & MN-HSS3-G04 & 5e-30 & + \\
$\begin{array}{l}\text { Proteína Transportadora ABC } \\
\text { [Oryza sativa] BAC55994 }\end{array}$ & MN-HSS2-G04 & $7 \mathrm{e}-16$ & + \\
\hline
\end{tabular}

${ }^{1}$ A função de cada gene foi detectada por comparação com seqüências homólogas presentes no NCBI, utilizando-se o programa BlastX. A função associada à seqüência de maior homologia detectada para cada clone de cDNA de cafeeiro, foi relacionada juntamente com a respectiva origem (espécie do organismo e número de acesso do GenBank). ${ }^{2}$ Genes isolados por hibridização subtrativa por supressão, a partir de mRNAs de cafeeiro Mundo Novo tratado com ASM. ${ }^{3} \mathrm{O}$ valor de E foi utilizado para indicar a significância da similaridade de seqüência encontrada para cada gene. ${ }^{4}$ A confirmação da expressão de cada gene isolado de planta tratada foi determinada utilizando-se a técnica da seleção diferencial. +: gene induzido; -: gene não induzido.

No quarto grupo de genes isolados de cafeeiro cv. Mundo Novo tratado com ASM encontram-se aqueles implicados na síntese de compostos de baixo peso molecular, como os reguladores vegetais ácido jasmônico ou etileno, que apresentam uma função sinalizadora de respostas de resistência, resultando na ativação da expressão de proteínas antifúngicas ou de outros compostos de defesa (Tabela 7). Foi possível isolar de cafeeiro, três clones de genes codificadores da enzima S-adenosil-L-metionina 
sintetase (SAM sintetase, ciclo de Yang), que pode levar à síntese de etileno ou de poliaminas e um clone codificador de arginina descarboxilase, enzima da biossíntese de poliaminas. Foram isolados, também, genes codificadores da aleno óxido sintase, enzima chave na síntese de ácido jasmônico (JA) e da proteína ácido jasmônico 2, reguladora específica da via sinalizadora mediada por JA em plantas, como pode ser observado na Tabela 7. A análise através do programa CD-Search do NCBI revelou, que as proteínas codificadas pelos genes isolados de cafeeiro, clones MN-HSS1-D07, MNHSS4-G10 e MN-HSS2-F08 apresentaram, também, três domínios conservados de SAM-sintetase. A proteína codificada pelo clone MN-HSS3-F03 apresentou o domínio conservado, SpeA, de arginina descarboxilase, característico de enzimas envolvidas na biossíntese da poliamina espermidina (NCBI-Conserved Domain Search).

Foi possível isolar de cafeeiro cv. Mundo Novo tratado com ASM, um quinto grupo de genes envolvidos na percepção e transdução de sinal, como aqueles codificadores de proteína fosfatase, proteínas quinases, proteínas quinases tipo receptoras (RLKs), proteína de ligação à calmodulina e proteína de resistência à doenças com repetições ricas em leucina (Tabela 8). O clone MN-HSS3-A09, codificador de glutamato descarboxilase (GAD), enzima que catalisa a síntese do ácido gama-amino butírico (GABA), apresentou similaridade com uma proteína GAD capaz de se ligar à calmodulina, a qual apresenta sítios de ligação para o íon cálcio (Tabela 8). Como pode ser observado na Tabela 8, foram detectados três clones de genes codificadores de quinases que modificam, por fosforilação, proteínas alvo nos resíduos específicos de serina e treonina, sendo que o clone MN-HSS1-A10 apresentou similaridade com uma quinase capaz de interagir com a proteína tipo calcineurina B sensora de cálcio. A análise através do programa CD-Search do NCBI revelou, que as proteínas codificadas pelos três clones de genes, MN-HSS3-G10, MN-HSS3-H06 e MN-HSS1-A10 apresentaram, também, vários domínios conservados de serina/treonina quinases. Foram isolados dois genes, clones MN-HSS2-G03 e MN-HSS2-D09, que apresentaram similaridade com quinases tipo receptoras com domínio extracelular de lectina, capazes de se ligarem a carboidratos e envolvidas, portanto, na percepção de sinais, como oligossacarídeos ou outros fragmentos de parede celular. Foi possível verificar, também, 
a presença de vários domínios de serina/treonina quinases e de tirosina quinases, nas proteínas codificadas por esses genes. Por outro lado, o clone MN-HSS3-C07 apresentou similaridade com uma proteína contendo repetições ricas em leucina (LRR), envolvida em interações com outras moléculas sinalizadoras de natureza protéica. A análise através do NCBI-CD-Search revelou, que as proteínas codificadas pelos genes isolados de cafeeiro, clones MN-HSS1-C11, MN-HSS3-A09 e MN-HSS3-C07, apresentaram, também, os domínios conservados de proteína fosfatase 2A, glutamato descarboxilase e domínio LRR, respectivamente.

Tabela 7. Genes isolados de cafeeiro Mundo Novo tratado com ASM, envolvidos na síntese de compostos de baixo peso molecular com função sinalizadora de respostas de defesa.

\begin{tabular}{llcc}
\hline \multicolumn{1}{c}{ Função (n de acesso) ${ }^{1}$} & Clone ${ }^{2}$ & Valor de E $^{3}$ & $\begin{array}{c}\text { Expressão } \\
\text { diferencial do } \\
\text { gene }^{4}\end{array}$ \\
\hline $\begin{array}{l}\text { Ácido jasmônico } 2 \text { [Lycopersicon } \\
\text { esculentum] AAF04915 }\end{array}$ & MN-HSS3-B09 & 1e-60 & + \\
$\begin{array}{l}\text { Aleno óxido sintase [Lycopersicon } \\
\text { esculentum] CAB88032 }\end{array}$ & MN-HSS1-F08 & 5e-46 & + \\
$\begin{array}{l}\text { S-Adenosil-L-metionina sintetase 3 } \\
\text { [Catharanthus roseus] Q96553 }\end{array}$ & MN-HSS2-F08 & 2e-66 & + \\
$\begin{array}{l}\text { S-Adenosil-L-metionina sintetase } \\
\text { [Nicotiana tabacum] AAF42974 }\end{array}$ & MN-HSS1-D07, & 2e-11 & + \\
$\begin{array}{l}\text { Arginina descarboxilase ADC-1 } \\
\text { [Nicotiana sylvestris] T15046 }\end{array}$ & MN-HSS4-G10 & & + \\
\hline
\end{tabular}

${ }^{1}$ A função de cada gene foi detectada por comparação com seqüências homólogas presentes no NCBI, utilizando-se o programa BlastX. A função associada à seqüência de maior homologia detectada para cada clone de cDNA de cafeeiro, foi relacionada juntamente com a respectiva origem (espécie do organismo e número de acesso do GenBank). ${ }^{2}$ Genes isolados por hibridização subtrativa por supressão, a partir de mRNAs de cafeeiro Mundo Novo tratado com ASM. ${ }^{3} \mathrm{O}$ valor de E foi utilizado para indicar a significância da similaridade de seqüência encontrada para cada gene. ${ }^{4}$ A confirmação da expressão de cada gene isolado de planta tratada foi determinada utilizando-se a técnica da seleção diferencial. +: gene induzido; -: gene não induzido. 
Tabela 8. Genes isolados de cafeeiro Mundo Novo tratado com ASM, envolvidos na percepção e transdução do sinal de resistência.

\begin{tabular}{|c|c|c|c|}
\hline Função (n ${ }^{\circ}$ de acesso) ${ }^{1}$ & Clone $^{2}$ & Valor de $\mathrm{E}^{3}$ & $\begin{array}{l}\text { Expressão } \\
\text { diferencial do }^{4} \text { gene }^{4}\end{array}$ \\
\hline $\begin{array}{l}\text { Proteína fosfatase } 2 \text { A [Arabidopsis } \\
\text { thaliana] NP189208 }\end{array}$ & MN-HSS1-C11 & $6 e-34$ & + \\
\hline $\begin{array}{l}\text { Proteína de ligação à calmodulina } \\
\text { Glutamato descarboxilase (GAD) } \\
\text { [Petunia hybrida] Q07346 }\end{array}$ & MN-HSS3-A09 & $1 \mathrm{e}-42$ & + \\
\hline $\begin{array}{l}\text { Proteína quinase de interação com } \\
\text { proteína tipo calcineurina B (CBL) - } \\
\text { CIPK 11[Arabidopsis thaliana] } \\
\text { NP180595 }\end{array}$ & MN-HSS1-A10 & $2 e-56$ & + \\
\hline $\begin{array}{l}\text { Proteína serina/treonina quinase } \\
\text { [Oryza sativa] AAM19110 }\end{array}$ & $\begin{array}{c}\text { MN-HSS3-G10 e } \\
\text { H06 }\end{array}$ & $6 e-15$ & + \\
\hline $\begin{array}{l}\text { Proteína quinase tipo lectina } \\
\text { receptora [Arabidopsis thaliana] } \\
\text { NP181307 }\end{array}$ & MN-HSS2-G03 & $3 e-49$ & + \\
\hline $\begin{array}{l}\text { Proteína quinase tipo lectina } \\
\text { receptora (RLK) [Populus nigra] } \\
\text { BAA82556 }\end{array}$ & MN-HSS2-D09 & $2 e-25$ & + \\
\hline $\begin{array}{l}\text { Proteína quinase tipo receptora } \\
\text { [Arabidopsis thaliana] AAL32637 }\end{array}$ & MN-HSS2-H02 & 3e-13 & - \\
\hline $\begin{array}{l}\text { Proteína de resistência à doenças } \\
\text { com repetições ricas em leucina } \\
\text { [Arabidopsis thaliana] AAM63268 }\end{array}$ & MN-HSS3-C07 & $1 e-29$ & + \\
\hline
\end{tabular}

${ }^{1}$ A função de cada gene foi detectada por comparação com seqüências homólogas presentes no NCBI, utilizando-se o programa BlastX. A função associada à seqüência de maior homologia detectada para cada clone de cDNA de cafeeiro, foi relacionada juntamente com a respectiva origem (espécie do organismo e número de acesso do GenBank). ${ }^{2}$ Genes isolados por hibridização subtrativa por supressão, a partir de mRNAs de cafeeiro Mundo Novo tratado com ASM. ${ }^{3} \mathrm{O}$ valor de E foi utilizado para indicar a significância da similaridade de seqüência encontrada para cada gene. ${ }^{4}$ A confirmação da expressão de cada gene isolado de planta tratada foi determinada utilizando-se a técnica da seleção diferencial. +: gene induzido; -: gene não induzido. 
Como pode ser observado na Tabela 9, um grupo de proteínas codificadas pelos clones de cDNA, isolados de cafeeiro cv. Mundo Novo tratado com ASM estão relacionadas com o metabolismo de lipídeos. Os cinco clones isolados apresentaram similaridade significativa com genes codificadores das enzimas acil-CoA sintetase, envolvida na esterificação de ácidos graxos, esteróide 5-alfa-redutase (3-oxo-5-alfaesteróide 4-desidrogenase), lipase tipo GDSL e serina C-palmitoiltransferase, enzima chave da biossíntese de esfingolipídeos (Tabela 9). A análise através do NCBI-CDSearch revelou, que as proteínas codificadas pelos genes isolados de cafeeiro, clones MN-HSS3-E11, MN-HSS2-E07 e MN-HSS4-H05, apresentaram, também, os domínios específicos de esteróide 5-alfa-redutase, lipase/acilhidrolase tipo GDSL e serina palmitoiltransferase, respectivamente.

Foi possível isolar de cafeeiro cv. Mundo Novo tratado com ASM, um grupo de genes implicados na degradação controlada de proteínas, a qual é mediada pelo complexo proteassomo/ubiquitina com a ação de ubiquitina ligases (Tabela 10). A proteína codificada pelo clone MN-HSS3-D07 apresentou similaridade com uma ubiquitina ligase da classe "Ring finger". Os clones MN-HSS1-A12, MN-HSS1-B10 e MN-HSS4-C04, apresentaram, também, vários domínios conservados correspondentes à ubiquitina (NCBI/CD-Search). O mesmo foi observado para o clone MN-HSS2-H11, que apresentou domínios do complexo proteassomo 20S (subunidade reguladora alfa), que realiza a proteólise de proteínas alvo marcadas com ubiquitina (NCBI/CD-Search).

Além dos genes relacionados à resistência de plantas contra fitopatógenos (Tabelas 4, 5, 6, 7, 8, 9 e 10), foi verificado que 116 clones de cDNA apresentaram similaridade significativa com genes envolvidos na manutenção celular e desenvolvimento vegetal (Tabela 11). As funções encontradas para os genes isolados de cafeeiro cv. Mundo Novo tratado com ASM estão relacionadas a diversos processos, como por exemplo, fotossíntese, divisão e crescimento celular, vias biosintéticas do metabolismo primário, como a glicólise, além de proteínas estruturais. 
Tabela 9. Genes de cafeeiro Mundo Novo tratado com ASM, envolvidos no metabolismo de lipídeos.

\begin{tabular}{lccc}
\hline \multicolumn{1}{c}{${\text { Função (n }{ }^{\circ} \text { de acesso) }}^{1}$} & Clone $^{2}$ & Valor de E $^{3}$ & $\begin{array}{c}\text { Expressão } \\
\text { diferencial do }^{4} \\
\text { gene }^{4}\end{array}$ \\
\hline $\begin{array}{l}\text { Acil-CoA sintetase [Capsicum } \\
\text { annuum] AAL29212 }\end{array}$ & MN-HSS4-G07 & 6e-08 & + \\
$\begin{array}{l}\text { Esteróide 5-alfa-reductase } \\
\text { [Arabidopsis thaliana] NP197105 }\end{array}$ & MN-HSS3-E11 & 2e-17 & + \\
$\begin{array}{l}\text { Possível lipase/acilhidrolase com } \\
\text { motivo GDSL [Arabidopsis thaliana] }\end{array}$ & $\begin{array}{l}\text { MN-HSS2-E07, } \\
\text { AAM65485 }\end{array}$ & 2e-59 & + \\
$\begin{array}{l}\text { Serina C-palmitoiltransferase } \\
\text { [Solanum tuberosum] CAB44316 }\end{array}$ & MN-HSS4-H05 & 2e-40 & + \\
\hline
\end{tabular}

${ }^{1}$ A função de cada gene foi detectada por comparação com seqüências homólogas presentes no NCBI, utilizando-se o programa BlastX. A função associada à seqüência de maior homologia detectada para cada clone de cDNA de cafeeiro, foi relacionada juntamente com a respectiva origem (espécie do organismo e número de acesso do GenBank). ${ }^{2}$ Genes isolados por hibridização subtrativa por supressão, a partir de mRNAs de cafeeiro Mundo Novo tratado com ASM. ${ }^{3} \mathrm{O}$ valor de $\mathrm{E}$ foi utilizado para indicar a significância da similaridade de seqüência encontrada para cada gene. ${ }^{4}$ A confirmação da expressão de cada gene isolado de planta tratada foi determinada utilizando-se a técnica da seleção diferencial. +: gene induzido; -: gene não induzido. 
Tabela 10. Genes de cafeeiro Mundo Novo tratado com ASM, envolvidos na degradação controlada de proteínas.

\begin{tabular}{lccc}
\hline \multicolumn{1}{c}{ Função (n de acesso) ${ }^{1}$} & Clone $^{2}$ & Valor de E $^{3}$ & $\begin{array}{c}\text { Expressão } \\
\text { diferencial do } \\
\text { gene }^{4}\end{array}$ \\
\hline $\begin{array}{l}\text { Proteína “Ring finger” BRH1 } \\
\text { (ubiquitina proteína ligase) }\end{array}$ & MN-HSS3-D07 & 5e-18 & + \\
$\begin{array}{l}\text { [Arabidopsis thaliana] NP191705 } \\
\text { Poliubiquitina [Nicotiana tabacum] }\end{array}$ & $\begin{array}{c}\text { MN-HSS1-A12 e } \\
\text { CAC84144 }\end{array}$ & B10, MN-HSS4- \\
C04 & & + \\
$\begin{array}{l}\text { Subunidade alfa do proteassomo } \\
\text { 20S [Arabidopsis thaliana] NP180270 }\end{array}$ & MN-HSS2-H11 & 1e-07 & - \\
\hline
\end{tabular}

${ }^{1}$ A função de cada gene foi detectada por comparação com seqüências homólogas presentes no NCBI, utilizando-se o programa BlastX. A função associada à seqüência de maior homologia detectada para cada clone de cDNA de cafeeiro, foi relacionada juntamente com a respectiva origem (espécie do organismo e número de acesso do GenBank). ${ }^{2}$ Genes isolados por hibridização subtrativa por supressão, a partir de mRNAs de cafeeiro Mundo Novo tratado com ASM. ${ }^{3} \mathrm{O}$ valor de E foi utilizado para indicar a significância da similaridade de seqüência encontrada para cada gene. ${ }^{4}$ A confirmação da expressão de cada gene isolado de planta tratada foi determinada utilizando-se a técnica da seleção diferencial. +: gene induzido; -: gene não induzido. 
Tabela 11. Genes de cafeeiro Mundo Novo tratado com ASM, apresentando funções relacionadas à manutenção celular e desenvolvimento vegetal.

\begin{tabular}{|c|c|c|c|}
\hline Função (nº de acesso) ${ }^{1}$ & Clone $^{2}$ & Valor de $\mathrm{E}^{3}$ & $\begin{array}{c}\text { Expressão } \\
\text { diferencial do } \\
\text { gene }^{4}\end{array}$ \\
\hline $\begin{array}{l}\text { Ácido graxo elongase } 1 \text { [Limnanthes } \\
\text { douglasii] AAG28600 }\end{array}$ & MN-HSS2-G01 & $5 e-80$ & - \\
\hline Actina [Coleochaete scutata] 065315 & $\begin{array}{l}\text { MN-HSS2-G05 e } \\
\text {-G09 }\end{array}$ & 2e-31 & + \\
\hline Actina [Lactuca sativa] AAP20773 & MN-HSS1-H08 & $2 \mathrm{e}-42$ & + \\
\hline Actina [Pisum sativum] P30164 & MN-HSS2-F01 & $5 e-72$ & + \\
\hline $\begin{array}{l}\text { Alanina aminotransferase [Arabidopsis } \\
\text { thaliana] NP177215 }\end{array}$ & $\begin{array}{l}\text { MN-HSS3-F07 e } \\
\text {-H08 }\end{array}$ & 3e-30 & + \\
\hline $\begin{array}{l}\text { Álcool desidrogenase ADH } \\
\text { [Lycopersicon esculentum] AAB33480 }\end{array}$ & MN-HSS3-D04 & $5 e-16$ & + \\
\hline $\begin{array}{l}\text { Apoproteína (47 kDa) do fotosistema II } \\
\text { (PSII, gene psbB) [Nicotiana tabacum] }\end{array}$ & $\begin{array}{l}\text { MN-HSS1-B01, } \\
\text { MN-HSS2-D12 }\end{array}$ & $5 e-59$ & - \\
\hline NP054526 & & & \\
\hline $\begin{array}{l}\text { Apoproteína ( } 47 \text { kDa) do fotosistema II } \\
\text { (PSII, gene psbB) [Pisum sativum] }\end{array}$ & MN-HSS1-C09 & $1 \mathrm{e}-64$ & - \\
\hline $1612384 \mathrm{~A}$ & & & \\
\hline $\begin{array}{l}\text { ATP sintase da cadeia alfa (subunidade } \\
\text { reguladora) [Spinacia oleracea] }\end{array}$ & MN-HSS1-C08 & e-104 & + \\
\hline PO6450 & & & \\
\hline $\begin{array}{l}\text { ATP sintase da cadeia alfa (CF1) [Lotus } \\
\text { corniculatus] NP084803 }\end{array}$ & MN-HSS1-D04 & $9 e-30$ & + \\
\hline
\end{tabular}









\begin{tabular}{|c|c|c|c|}
\hline Função (nº de acesso) ${ }^{1}$ & Clone $^{2}$ & Valor de $\mathrm{E}^{3}$ & $\begin{array}{l}\text { Expressão } \\
\text { diferencial do } \\
\text { gene }^{4}\end{array}$ \\
\hline $\begin{array}{l}\text { Citocromo b6 (gene petB) [Atropa } \\
\text { belladonna] NP783261 }\end{array}$ & $\begin{array}{l}\text { MN-HSS2-B01, } \\
\text {-B08, -D07 }\end{array}$ & $2 e-63$ & + \\
\hline $\begin{array}{l}\text { Citocromo b6 (gene petB) [Zea mays] } \\
\text { AAB29194 }\end{array}$ & $\begin{array}{l}\text { MN-HSS1-E09, } \\
\text { MN-HSS3-A11 }\end{array}$ & 3e-27 & + \\
\hline $\begin{array}{l}\text { Citocromo b6/f (gene petD) [Zea mays] } \\
\text { CAA29002 }\end{array}$ & MN-HSS1-C12 & $1 \mathrm{e}-21$ & + \\
\hline $\begin{array}{l}\text { Citocromo B561 [Arabidopsis thaliana] } \\
\text { AAM62824 }\end{array}$ & MN-HSS1-D12 & $2 e-13$ & + \\
\hline $\begin{array}{l}\text { Citocromo P450 (97B2) [Glycine max] } \\
048921\end{array}$ & MN-HSS3-E09 & 3e-29 & + \\
\hline $\begin{array}{l}\text { Difosfatase inorgânica [Beta vulgaris] } \\
\text { T14563 }\end{array}$ & MN-HSS1-F05 & $1 \mathrm{e}-12$ & + \\
\hline $\begin{array}{l}\text { Endoxiloglucana transferase } \\
\text { [Gossypium hirsutum] TO9870 }\end{array}$ & MN-HSS4-G01 & $1 \mathrm{e}-12$ & - \\
\hline Exostoses [Oryza sativa] AAK14423 & MN-HSS3-A02 & 3e-61 & + \\
\hline $\begin{array}{l}\text { Extensina (HRGP) [Daucus carota] } \\
\text { PO6599 }\end{array}$ & MN-HSS3-B01 & 9e-04 & + \\
\hline $\begin{array}{l}\text { Fator alfa-1 de elongação da síntese } \\
\text { protéica [Nicotiana tabacum] } \\
\text { BAA09709 }\end{array}$ & MN-HSS1-F06 & 3e-79 & + \\
\hline $\begin{array}{l}\text { Fator de ribosilação do ADP [Glycine } \\
\text { max] AAD17207 }\end{array}$ & MN-HSS3-D02 & $4 e-44$ & + \\
\hline $\begin{array}{l}\text { 6-Fosfogluconato desidrogenase } \\
\text { [Glycine max] T05363 }\end{array}$ & MN-HSS4-C01 & $4 e-69$ & + \\
\hline $\begin{array}{l}\text { Glicogenina glicosiltransferase } \\
\text { [Arabidopsis thaliana] NP197349 }\end{array}$ & MN-HSS3-G11 & $2 \mathrm{e}-16$ & + \\
\hline
\end{tabular}




\begin{tabular}{|c|c|c|c|}
\hline Função ( $n^{\circ}$ de acesso) ${ }^{1}$ & Clone $^{2}$ & Valor de $\mathrm{E}^{3}$ & $\begin{array}{c}\text { Expressão } \\
\text { diferencial do } \\
\text { gene }^{4}\end{array}$ \\
\hline $\begin{array}{l}\text { Glicosil hidrolase família } 35 \text { ( } \beta \text { - } \\
\text { galactosidase) [Arabidopsis thaliana] }\end{array}$ & $\begin{array}{l}\text { MN-HSS2-G12 e } \\
- \text { H12 }\end{array}$ & $4 e-26$ & + \\
\hline NP568001 & & & \\
\hline $\begin{array}{l}\text { Glicosil transferase [Nicotiana } \\
\text { tabacum] BAB } 60720\end{array}$ & MN-HSS3-B05 & $1 \mathrm{e}-18$ & + \\
\hline $\begin{array}{l}\text { Glucose-6-fosfato isomerase } \\
\text { [Crucihimalaya himalaica] BAC11914 }\end{array}$ & MN-HSS1-E12 & 2e-99 & + \\
\hline $\begin{array}{l}\text { Hidrolase (tipo dehalogenase } \\
\text { haloácida) [Arabidopsis thaliana] }\end{array}$ & MN-HSS2-E09 & $9 e-20$ & + \\
\hline NP565738 & & & \\
\hline $\begin{array}{l}\text { Metalotioneína [Citrus unshiu] } \\
\text { BAA31562 }\end{array}$ & $\begin{array}{l}\text { MN-HSS1-C02, } \\
\text {-C06, -E08 e -H02; } \\
\text { MN-HSS2-B11 e } \\
\text {-H10; MN-HSS3- } \\
\text { E02, -F01 e -F02; } \\
\text { MN-HSS4-F08, } \\
\text {-G03 e -H08 }\end{array}$ & 3e-22 & - \\
\hline $\begin{array}{l}\text { Monoxigenase contendo flavina (FMO) } \\
\text { [Arabidopsis thaliana] NP175321 }\end{array}$ & $\begin{array}{l}\text { MN-HSS3-C08, } \\
\text { MN-HSS4-D03 }\end{array}$ & 7e-31 & + \\
\hline $\begin{array}{l}\text { NADH desidrogenase subunidade K } \\
\text { [Atropa belladonna] NP783236 }\end{array}$ & MN-HSS3-D01 & $1 e-44$ & + \\
\hline $\begin{array}{l}\text { NADH desidrogenase subunidade A } \\
\text { [Phoenix dactylifera] AAO27802 }\end{array}$ & MN-HSS4-A05 & $9 e-47$ & + \\
\hline $\begin{array}{l}\text { NADH desidrogenase subunidade } 1 \\
\text { [Spinacia oleracea] NP054993 }\end{array}$ & MN-HSS1-A08 & $2 e-33$ & + \\
\hline $\begin{array}{l}\text { NAD(P)H-quinone oxidoreductase, } \\
\text { cadeia } 1 \text { [Nicotiana tabacum] P06254 }\end{array}$ & MN-HSS3-D11 & $4 e-15$ & + \\
\hline
\end{tabular}




\begin{tabular}{|c|c|c|c|}
\hline Função (nº de acesso) ${ }^{1}$ & Clone $^{2}$ & Valor de $\mathrm{E}^{3}$ & $\begin{array}{l}\text { Expressão } \\
\text { diferencial do } \\
\text { gene }^{4}\end{array}$ \\
\hline $\begin{array}{l}\text { 4-Nitrofenilfosfatase (hidrolase tipo } \\
\text { dehalogenase haloácida) [Arabidopsis } \\
\text { thaliana] BAA98057 }\end{array}$ & MN-HSS3-B04 & $6 e-72$ & + \\
\hline $\begin{array}{l}\text { Oxidoredutase de ligação ao zinco } \\
\text { [Arabidopsis thaliana] NP193037 }\end{array}$ & MN-HSS3-C09 & 3e-20 & + \\
\hline $\begin{array}{l}\text { Oxidoredutase ligada à FAD (possível } \\
\text { proteína tipo reticulina oxidase) } \\
\text { [Arabidopsis thaliana] NP174359 }\end{array}$ & MN-HSS3-G09 & $7 e-24$ & + \\
\hline $\begin{array}{l}\text { Peptidilprolil cis-trans isomerase } \\
\text { [Oryza sativa] CAD89783 }\end{array}$ & MN-HSS1-D05 & $4 \mathrm{e}-12$ & + \\
\hline $\begin{array}{l}\text { Pirrolina-5-carboxilato redutase [Pisum } \\
\text { sativum] QO4708 }\end{array}$ & MN-HSS1-H03 & 1e-15 & - \\
\hline $\begin{array}{l}\text { Plastoquinol-plastocianina redutase } \\
\text { [Nicotiana tabacum] WMNT17 }\end{array}$ & MN-HSS2-H03 & $1 \mathrm{e}-20$ & - \\
\hline $\begin{array}{l}\text { Polipeptídeo 10kDa do fotosistema II } \\
\text { (PII10) [Nicotiana tabacum] Q40519 }\end{array}$ & $\begin{array}{l}\text { MN-HSS3-A05, } \\
\text { MN-HSS4-B05 }\end{array}$ & $6 e-28$ & + \\
\hline $\begin{array}{l}\text { Proteína da família de domínio PsbQ } \\
\text { [Arabidopsis thaliana] NP566137 }\end{array}$ & MN-HSS1-F03 & $6 e-18$ & + \\
\hline $\begin{array}{l}\text { Proteína de choque térmico Hsp70 } \\
\text { (chaperona) [Lycopersicon esculentum] } \\
\text { P27322 }\end{array}$ & $\begin{array}{c}\text { MN-HSS2-C01 e } \\
\text {-C03 }\end{array}$ & $2 e-67$ & + \\
\hline $\begin{array}{l}\text { Proteína de ligação da clorofila a/b } \\
\text { [Arabidopsis thaliana] NP177783 }\end{array}$ & MN-HSS1-H07 & $4 e-35$ & + \\
\hline $\begin{array}{l}\text { Proteína de ligação da clorofila a/b } \\
\text { [Ginkgo biloba] AAB34067 }\end{array}$ & MN-HSS2-H09 & $8 e-41$ & - \\
\hline
\end{tabular}




\begin{tabular}{|c|c|c|c|}
\hline Função ( ${ }^{\circ}$ de acesso) ${ }^{1}$ & Clone $^{2}$ & Valor de $\mathrm{E}^{3}$ & $\begin{array}{l}\text { Expressão } \\
\text { diferencial do } \\
\text { gene }^{4}\end{array}$ \\
\hline $\begin{array}{l}\text { Proteína de ligação da clorofila a/b } \\
\text { [Gossypium hirsutum] T09838 }\end{array}$ & MN-HSS1-F12 & 3e-24 & - \\
\hline $\begin{array}{l}\text { Proteína de ligação da clorofila a/b } \\
\text { [Lycopersicon esculentum] P14279 }\end{array}$ & MN-HSS3-G08 & 2e-09 & + \\
\hline $\begin{array}{l}\text { Proteína de ligação da clorofila a/b } \\
\text { [Nicotiana tabacum] P27494 }\end{array}$ & MN-HSS1-D06 & e-104 & - \\
\hline $\begin{array}{l}\text { Proteína de ligação da clorofila a/b } \\
\text { [Pisum sativum] S33775 }\end{array}$ & MN-HSS2-A09 & $1 \mathrm{e}-07$ & + \\
\hline $\begin{array}{l}\text { Proteína de maturação de semente } \\
\text { PM23 [Glycine max] AAF21309 }\end{array}$ & MN-HSS4-E10 & $2 e-35$ & + \\
\hline $\begin{array}{l}\text { Proteína de mitocôndria [Arabidopsis } \\
\text { thaliana] NP567730 }\end{array}$ & MN-HSS4-F09 & $8 e-08$ & + \\
\hline $\begin{array}{l}\text { Proteína do látex tipo aldolase [Hevea } \\
\text { brasiliensis] AAM46780 }\end{array}$ & MN-HSS2-G11 & $5 e-37$ & + \\
\hline $\begin{array}{l}\text { Proteína do retículo endoplasmático } \\
\text { AtRer1A [Arabidopsis thaliana] }\end{array}$ & MN-HSS3-A12 & 1e-14 & + \\
\hline NP195633 & & & \\
\hline $\begin{array}{l}\text { Proteína do retículo endoplasmático } \\
\text { Rer1A [Oryza sativa] BAB16908 }\end{array}$ & MN-HSS1-E01 & $4 \mathrm{e}-07$ & + \\
\hline $\begin{array}{l}\text { Proteína Erg-1 (similar à phi-1) } \\
\text { [Solanum tuberosum] AAP42136 }\end{array}$ & MN-HSS4-B01 & $8 e-06$ & + \\
\hline Proteina induzida por desidratação & MN-HSS1-E05 e & $4 e-35$ & + \\
\hline RD22 [Gossypium hirsutum] & -F11, MN-HSS2- & & \\
\hline AAL67991 & D10 & & \\
\hline $\begin{array}{l}\text { Proteína integral de membrana } \\
\text { [Arabidopsis thaliana] NP565550 }\end{array}$ & MN-HSS1-H04 & $5 e-15$ & + \\
\hline
\end{tabular}




\begin{tabular}{|c|c|c|c|}
\hline Função (nº de acesso) ${ }^{1}$ & Clone $^{2}$ & Valor de $\mathrm{E}^{3}$ & $\begin{array}{l}\text { Expressão } \\
\text { diferencial do } \\
\text { gene }^{4}\end{array}$ \\
\hline $\begin{array}{l}\text { Proteína principal da partícula pequena } \\
\text { do látex (relacionada ao estresse) } \\
\text { (SRPP) [Hevea brasiliensis] } \\
\text { AAO66433 }\end{array}$ & MN-HSS2-H04 & $1 \mathrm{e}-29$ & + \\
\hline $\begin{array}{l}\text { Proteína PDI (dissulfeto isomerase) } \\
\text { [Nicotiana tabacum] TO3644 }\end{array}$ & MN-HSS3-H09 & $2 e-20$ & + \\
\hline $\begin{array}{l}\text { Proteína PDI (dissulfeto isomerase) } \\
\text { [Quercus suber] CAC87937 }\end{array}$ & MN-HSS1-A02 & $8 e-26$ & + \\
\hline $\begin{array}{l}\text { Proteína regulada no amadurecimento } \\
\text { [Oryza sativa] AAN64140 }\end{array}$ & MN-HSS4-B12 & $6 e-13$ & + \\
\hline $\begin{array}{l}\text { Proteína regulada por auxina } \\
\text { [Arabidopsis thaliana] NP850016 }\end{array}$ & MN-HSS2-C09 & 3e-08 & + \\
\hline $\begin{array}{l}\text { Proteína regulada por auxina } \\
\text { [Arabidopsis thaliana] NP191628 }\end{array}$ & $\begin{array}{l}\text { MN-HSS4-A01 e } \\
\text {-A07 }\end{array}$ & $2 e-25$ & + \\
\hline $\begin{array}{l}\text { Proteína ribossomal S26 [Medicago } \\
\text { sativa] T50823 }\end{array}$ & MN-HSS4-E02 & 7e-18 & + \\
\hline $\begin{array}{l}\text { Proteína ribossomal L6 } 60 \text { S } \\
\text { [Mesembryanthemum crystallinum] } \\
\text { P34091 }\end{array}$ & MN-HSS2-C06 & $7 e-16$ & + \\
\hline $\begin{array}{l}\text { Proteína ribossomal L26 [Zea mays] } \\
\text { AAC64166 }\end{array}$ & $\begin{array}{l}\text { MN-HSS4-A03 e } \\
\text {-E09 }\end{array}$ & $4 e-28$ & + \\
\hline $\begin{array}{l}\text { Proteína Rieske ferro-enxofre } \\
\text { (complexo citocromo B6-F) [Nicotiana } \\
\text { tabacum] QO2585 }\end{array}$ & MN-HSS1-B02 & 3e-19 & + \\
\hline $\begin{array}{l}\text { Proteína secretora de } 33 \text { kDa } \\
\text { [Arabidopsis thaliana] NP199665 }\end{array}$ & MN-HSS3-F11 & $1 \mathrm{e}-29$ & + \\
\hline
\end{tabular}




\begin{tabular}{|c|c|c|c|}
\hline Função (n ${ }^{\circ}$ de acesso) ${ }^{1}$ & Clone $^{2}$ & Valor de $\mathrm{E}^{3}$ & $\begin{array}{l}\text { Expressão } \\
\text { diferencial do } \\
\text { gene }^{4}\end{array}$ \\
\hline $\begin{array}{l}\text { Proteína Tha4 [Pisum sativum] } \\
\text { AAD33943 }\end{array}$ & MN-HSS3-D12 & $6 e-26$ & + \\
\hline $\begin{array}{l}\text { Proteína transportadora de fosfato } \\
\text { inorgânico [Catharanthus roseus] } \\
\text { TO7808 }\end{array}$ & MN-HSS1-H10 & 3e-39 & + \\
\hline $\begin{array}{l}\text { Regulador de transcrição [Arabidopsis } \\
\text { thaliana] NP564640 }\end{array}$ & MN-HSS1-F04 & $8 e-13$ & + \\
\hline $\begin{array}{l}\text { Ribonucleoproteína F (snRNP, proteína } \\
\text { APG rica em prolina) [Arabidopsis } \\
\text { thaliana] NP194751 }\end{array}$ & MN-HSS1-B08 & $4 e-18$ & + \\
\hline $\begin{array}{l}\text { Ribonucleoproteína tipo tioredoxina } \\
\text { (snRNP, U5) [Oryza sativa] AAL59040 }\end{array}$ & MN-HSS1-D08 & 2e-21 & + \\
\hline $\begin{array}{l}\text { Ribulose-1,5-bisfosfato carboxilase } \\
\text { (Rubisco activase) [Haplomitrium } \\
\text { mnioides] BAA83454 }\end{array}$ & MN-HSS4-A09 & $6 e-13$ & + \\
\hline $\begin{array}{l}\text { Rubisco activase [Coffea arabica] } \\
\text { CAA58609 }\end{array}$ & $\begin{array}{l}\text { MN-HSS4-C12 e } \\
\text {-D12 }\end{array}$ & 1e-39 & + \\
\hline $\begin{array}{l}\text { Rubisco activase [Zantedeschia } \\
\text { aethiopica] AAK25799 }\end{array}$ & MN-HSS2-F02 & $7 e-43$ & + \\
\hline $\begin{array}{l}\text { RNA polimerase cadeia alfa [Atropa } \\
\text { belladonna] NP783263 }\end{array}$ & MN-HSS2-F04 & $1 e-52$ & + \\
\hline $\begin{array}{l}\text { Rnase H [Arabidopsis thaliana] } \\
\text { NP186790 }\end{array}$ & MN-HSS1-G05 & $4 e-35$ & + \\
\hline $\begin{array}{l}\text { Tioredoxina [Arabidopsis thaliana] } \\
\text { AAM61520 }\end{array}$ & MN-HSS4-A04 & $5 e-07$ & + \\
\hline
\end{tabular}




\begin{tabular}{|c|c|c|c|}
\hline Função ( $n^{\circ}$ de acesso) ${ }^{1}$ & Clone $^{2}$ & Valor de $\mathrm{E}^{3}$ & $\begin{array}{c}\text { Expressão } \\
\text { diferencial do } \\
\text { gene }^{4}\end{array}$ \\
\hline $\begin{array}{l}\text { Tioredoxina [Arabidopsis thaliana] } \\
\text { NP177802 }\end{array}$ & MN-HSS4-C02 & 2e-23 & + \\
\hline $\begin{array}{l}\text { Translocase [Arabidopsis thaliana] } \\
\text { NP181277 }\end{array}$ & $\begin{array}{c}\text { MN-HSS3-C12 e } \\
-\mathrm{H} 11\end{array}$ & $1 e-04$ & + \\
\hline $\begin{array}{l}\text { Transportador de betaína/prolina } \\
\text { [Avicennia marina] BAB93110 }\end{array}$ & MN-HSS3-E07 & $7 e-16$ & + \\
\hline $\begin{array}{l}\text { Transportador de hexose [Lycopersicon } \\
\text { esculentum] CAB52689 }\end{array}$ & MN-HSS3-F05 & $8 e-21$ & + \\
\hline $\begin{array}{l}\text { Transportador de tetraciclina } \\
\text { [Arabidopsis thaliana] NP179290 }\end{array}$ & MN-HSS3-D06 & 2e-11 & + \\
\hline $\begin{array}{l}\text { Transportador de zinco - ZIP1 [Glycine } \\
\text { max] AAK37761 }\end{array}$ & $\begin{array}{l}\text { MN-HSS2-C12, } \\
\text {-G02, -G07 }\end{array}$ & 5e-06 & + \\
\hline $\begin{array}{l}\text { Trehalose-6-fosfato sintase } \\
\text { [Arabidopsis thaliana] H71447 }\end{array}$ & MN-HSS3-B02 & 3e-30 & + \\
\hline $\begin{array}{l}\text { UDP glucose 4-epimerase [Arabidopsis } \\
\text { thaliana] S62783 }\end{array}$ & MN-HSS3-B08 & $5 e-63$ & + \\
\hline
\end{tabular}

${ }^{1}$ A função de cada gene foi detectada por comparação com seqüências homólogas presentes no NCBI, utilizando-se o programa BlastX. A função associada à seqüência de maior homologia detectada para cada clone de cDNA de cafeeiro, foi relacionada juntamente com a respectiva origem (espécie do organismo e número de acesso do GenBank). ${ }^{2}$ Genes isolados por hibridização subtrativa por supressão, a partir de mRNAs de cafeeiro Mundo Novo tratado com ASM. ${ }^{3} \mathrm{O}$ valor de E foi utilizado para indicar a significância da similaridade de sequiência encontrada para cada gene. ${ }^{4}$ A confirmação da expressão de cada gene isolado de planta tratada foi determinada utilizando-se a técnica da seleção diferencial. +: gene induzido; -: gene não induzido. 


\subsubsection{Determinação por seleção diferencial da expressão de genes ativados em cafeeiro cv. Mundo Novo após tratamento com indutor de resistência}

Foi verificado que de um total de 384 clones de cDNA, presentes na biblioteca subtraída enriquecida de fragmentos de genes de cafeeiro cv. Mundo Novo tratado com ASM, 302 clones representam genes expressos diferencialmente. A expressão diferencial dos genes pôde ser confirmada através de seleção diferencial, possibilitando identificar os clones de cDNA presentes na biblioteca subtraída, que são expressos especificamente na planta induzida à resistência. Os resultados obtidos podem ser visualizados na Figura 8. Os clones de cDNA da biblioteca subtraída que hibridizaram apenas com a sonda induzida (cDNA I-SF) ou com as duas sondas, induzida e controle (cDNA C-SR), mas com intensidades diferentes, correspondem a genes expressos diferencialmente (Clontech "PCR-Select Differential Screening Kit User Manual", 2001a). Entretanto, os clones que hibridizaram com a sonda controle de forma similar à sonda induzida (diferença na intensidade de sinal menor que três vezes), representam os cDNAs presentes, também, na planta não induzida à resistência, que não foram removidos na HSS, não sendo, portanto, diferencialmente expressos (Figura 8a, b, c e d, membranas A).

Foram detectados, na biblioteca subtraída obtida de cafeeiro cv. Mundo Novo tratado com ASM, vários clones de genes codificadores da proteína intracelular não enzimática, metalotioneína, que apresenta alto conteúdo de cisteína e capacidade de ligação a vários metais pesados, podendo apresentar uma função na destoxificação celular (Tabela 11). Entretanto, todos estes clones de cDNA isolados, não são diferencialmente expressos nas plantas induzidas à resistência, pois são encontrados, também, em plantas não tratadas com ASM. Pode ser observado na Figura 8, que os clones, MN-HSS1- C02, -C06, -E08 e H02; MN-HSS2-B11 e H10; MN-HSS3-E02, F01 e F02 e MN-HSS4-F08, -G03 e -H08, codificadores de metalotioneína, hibridizaram também, com a sonda controle, obtida de planta não induzida. Outros clones de cDNA da biblioteca subtraída de Mundo Novo não foram especificamente induzidos nas condições estudadas, como aqueles codificadores de alguns compostos envolvidos na 
fotossíntese (Figura 8 e Tabela 11). Nas Figuras 8a e b, por exemplo, pode ser observado, que os clones MN-HSS1-D06, MN-HSS1-F12 e MN-HSS2-H09, codificadores de proteínas de ligação da clorofila a/b, não são diferencialmente expressos, como também, os clones MN-HSS1-C09 e MN-HSS2-D12 codificadores de proteínas do fotosistema II. O mesmo foi observado para os clones MN-HSS2-H01 e MN-HSS4-H10, codificadores de proteínas do fotosistema I e para o clone MN-HSS2H03 codificador da enzima plastoquinol-plastocianina redutase (Figura 8b, Figura 8d, Tabela 11). Entretanto, outros clones de genes envolvidos, também, na fotossíntese, foram ativados após tratamento com o ASM (Figura 8, Tabela 11).

Além destes, alguns clones de genes apresentando funções relacionadas à defesa de plantas contra fitopatógenos não foram ativados especificamente nas plantas induzidas à resistência. Pode ser observado na Figura 8b, por exemplo, que o clone MNHSS2-H02, codificador de uma proteína quinase tipo receptora, envolvida na percepção e transdução de sinal e o clone MN-HSS2-H11, codificador de um componente do complexo proteassomo 20s, envolvido na degradação controlada de proteínas, hibridizaram, também, com a sonda controle proveniente de plantas não tratadas com ASM (Figura 8b e Tabelas 8 e 10). O mesmo foi observado para o clone MN-HSS3B12 que apresentou maior similaridade com gene de quitinase isolado de Castanea sativa. 

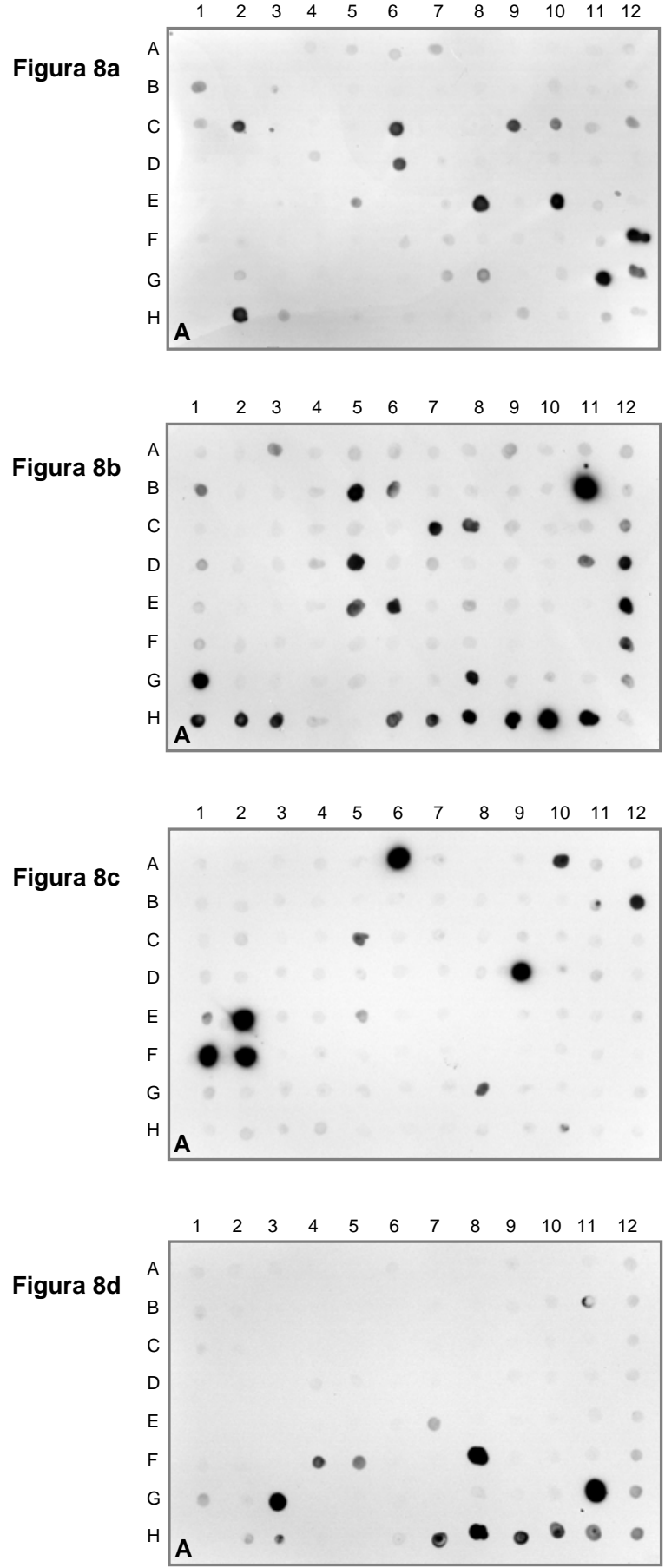
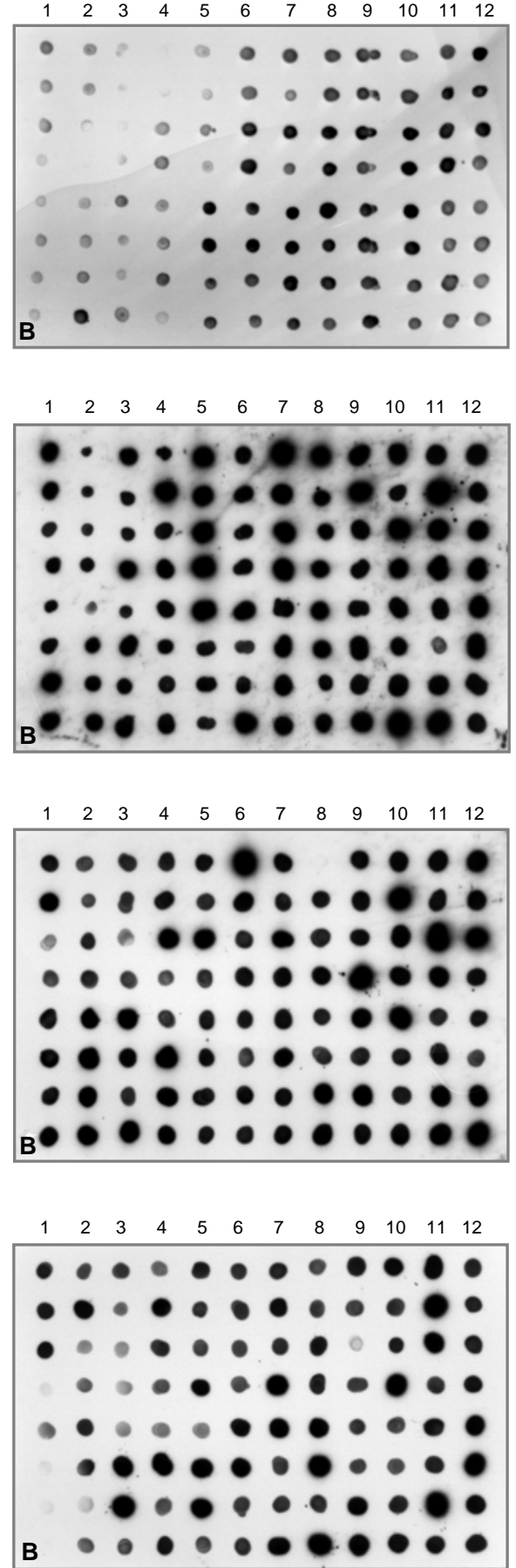

Figura 8 - Seleção diferencial dos clones de cDNA da biblioteca subtraída de cafeeiro cv. Mundo Novo tratado com acibenzolar-S-metil (ASM).

A: membranas hibridizadas com sonda de cDNA, proveniente de plantas controle; B: membranas hibridizadas com sonda de cDNA, proveniente de plantas tratadas com ASM. Sondas marcadas com digoxigenina; hibridização feita a $65^{\circ} \mathrm{C}$ por $16 \mathrm{~h}$. Figura 8a: $1^{\circ}$ grupo de clones de Mundo Novo, MN-HSS1; Figura 8b: $2^{\circ}$ grupo de clones, MN-HSS2; Figura 8c: $3^{\circ}$ grupo de clones, MN-HSS3; Figura 8d: $4^{\circ}$ grupo de clones, MN-HSS4. 


\subsection{Isolamento de genes de cafeeiro Híbrido de Timor associados à resistência vertical}

\subsubsection{Certificação da resistência do cafeeiro Híbrido de Timor contra $H$. vastatrix}

A avaliação feita 24 dias após a inoculação permitiu observar a presença de sintomas causados por $H$. vastatrix nas plantas suscetíveis cv. Mundo Novo e ausência dos mesmos nas plantas resistentes, Híbrido de Timor, inoculadas com a mesma suspensão do patógeno (Figura 9). Ocorreu esporulação nas lesões das folhas do cV. Mundo Novo, enquanto que as folhas de Híbrido de Timor não apresentaram quaisquer sinais macroscópicos de infecção. Esses resultados evidenciaram a resposta de resistência de plantas Híbrido de Timor, utilizadas no presente trabalho, ao patógeno $H$. vastatrix. Pela reação de suscetibilidade apresentada pelo cv. Mundo Novo pode-se inferir que o inóculo de urediniosporos de $H$. vastatrix utilizado, também, no tratamento de plantas Híbrido de Timor para o isolamento de genes relacionados à resistência vertical, foi capaz de causar infecção nas condições experimentais utilizadas.

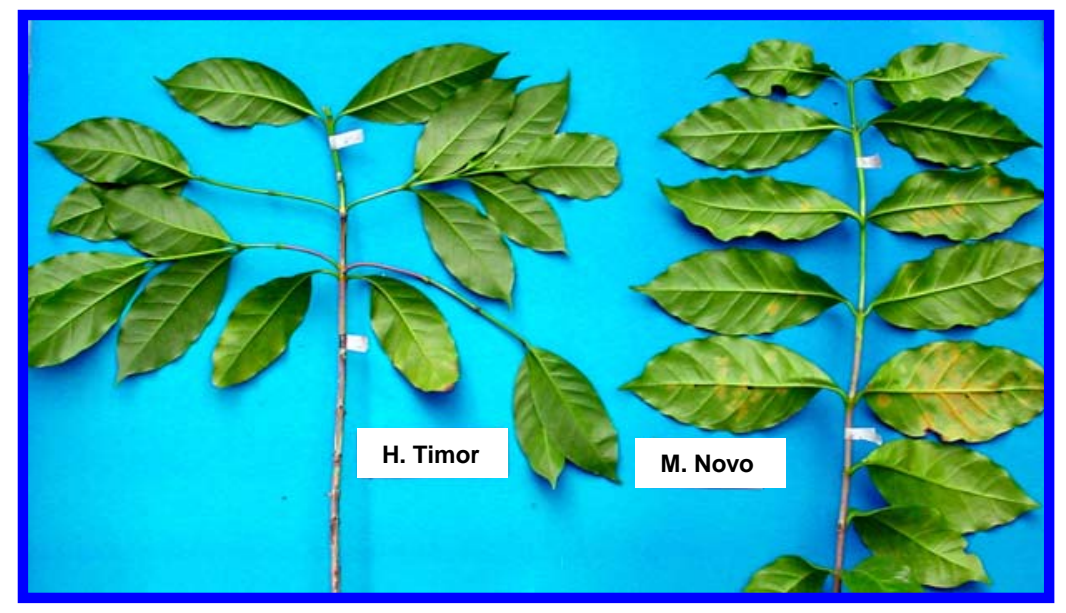

Figura 9 - Sintomas da ferrugem alaranjada do cafeeiro em plantas de café cv. Mundo Novo e Híbrido de Timor, inoculadas com uma suspensão de urediniosporos de $H$. vastatrix $(2 \mathrm{mg} / \mathrm{mL})$. 


\subsubsection{Isolamento por hibridização subtrativa por supressão de genes de cafeeiro Híbrido de Timor inoculado com $H$. Vastatrix}

Os cDNAs provenientes de plantas de café Híbrido de Timor, tratadas com água ou inoculadas com $H$. vastatrix (2 $\mathrm{mg} / \mathrm{mL})$, utilizados para a hibridização subtrativa por supressão (HSS), apresentaram concentrações iguais a $300 \mathrm{ng} / \mu \mathrm{L}$ e 367 ng/ $\mu \mathrm{L}$, respectivamente, após digestão com Rsa I e purificação. As amostras de plantas controle ou inoculadas com $H$. vastatrix, com volumes de 6,7 $\mu \mathrm{L}$ cada, apresentaram concentrações totais de cDNA iguais a 2,0 e 2,5 $\mu$ g, respectivamente. Os valores obtidos indicaram um rendimento dentro da faixa estabelecida para a metodologia empregada, que prevê a obtenção de 2 a $6 \mu$ ge cDNA purificados, sintetizados no final do processo (“SMART PCR cDNA Synthesis Kit User Manual”, 2000).

Os perfis eletroforéticos dos produtos das reações de PCR realizadas após a HSS forward (SF) e reverse (SR), enriquecidos, respectivamente, de fragmentos de cDNAs provenientes de plantas de café inoculadas com $H$. vastatrix (I-SF) ou com água (C-SR), podem ser visualizados na Figura 10. A eletroforese em gel de agarose revelou padrões distintos de bandas para as amostras de cDNAs subtraídas, provenientes da SF ou SR, em relação aos respectivos controles não subtraídos (controle tester nãosubtraído, controle driver não-subtraído), indicando que as hibridizações subtrativas foram realizadas de forma eficiente. Puderam ser visualizadas, também, bandas mais intensas na amostra I-SF, contendo cDNAs de plantas de café inoculadas com o patógeno, após subtração com os cDNAs das plantas controle tratadas com água, quando comparadas com aquelas presentes no produto da subtração reverse (amostra C-SR). O número menor de bandas observado na amostra C-SR, que contém os cDNAs de plantas de café tratadas com água, após subtração com os cDNAs das plantas inoculadas, sugere que a inoculação com $H$. vastatrix, induziu a expressão de genes em cafeeiro híbrido de Timor (Figura 10). 


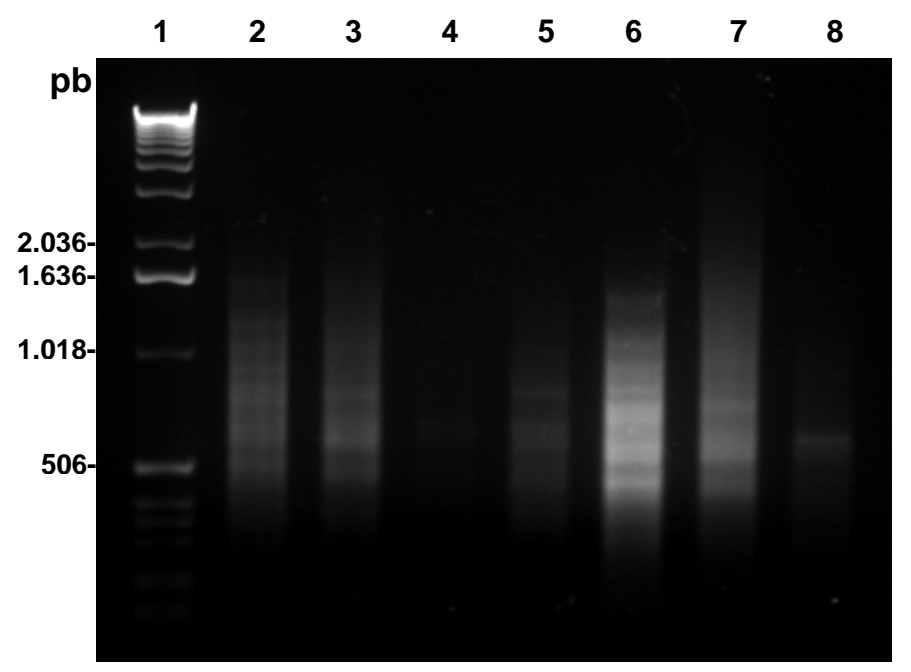

Figura 10 - Eletroforese em gel de agarose (1,5 \%) de cDNAs obtidos após hibridização subtrativa por supressão (HSS) e amplificação por PCR, provenientes de plantas de café Híbrido de Timor, inoculadas com $H$. vastatrix ou com água.

1: Padrão de DNA de 1Kb ladder; 2 a 5: produtos do primeiro PCR da HSS. 2cDNAs de plantas inoculadas, após subtração com cDNAs de plantas controle (ISF); 3- cDNAs de plantas inoculadas não-subtraídas (controle tester nãosubtraído); 4- cDNAs de plantas tratadas com água, após subtração com os cDNAs das plantas inoculadas (C-SR); 5- cDNAs de plantas controle não-subtraídas (controle driver não-subtraído). 6 a 8: produtos do segundo PCR da HSS. 6cDNAs de plantas inoculadas, após subtração; 7- cDNAs de planta inoculada não subtraída; 8- cDNAs de planta controle subtraída. pb: pares de base. Foram aplicados no gel $8 \mu \mathrm{L}$ de cada amostra.

\subsubsection{Seqüenciamento e avaliação da função de genes isolados de cafeeiro Híbrido de Timor inoculado com $H$. vastatrix}

As seqüências de 384 clones de cDNAs geradas após a HSS forward, comparadas com aquelas depositadas no NCBI utilizando-se o programa BlastX, permitiram identificar, em cafeeiros Híbrido de Timor inoculado com $H$. vastatrix, sete grupos de genes apresentando funções relacionadas à defesa de plantas contra fitopatógenos (Tabelas 12, 13, 14, 15, 16, 17 e 18) e um grupo associado à manutenção celular e desenvolvimento vegetal (Tabela 19). Foi verificado, também, que 47 clones de 
cafeeiro apresentaram similaridade com seqüências presentes no banco de dados, correspondentes a genes codificadores de proteínas com funções desconhecidas, designadas por proteínas hipotéticas, sendo a maioria isolada de A. thaliana. Foi constatado, ainda, que 158 clones de cDNA da biblioteca subtraída enriquecida de fragmentos de genes de plantas de café inoculadas, não apresentaram similaridade com sequiências do GenBank ou apresentaram homologias com valores de E maiores do que $10^{-3}$ (1e-03), não sendo, portanto, consideradas significativas.

Os clones de cDNA isolados de cafeeiro inoculado com $H$. vastatrix, que apresentaram similaridade significativa com genes do GenBank codificadores de proteínas conhecidas, foram relacionados em diferentes grupos, de acordo com a categoria funcional encontrada para cada gene. Nas Tabelas 12, 13, 14, 15, 16, 17 e 18 estão relacionados os clones com as funções encontradas para os genes de cafeeiro Híbrido de Timor, envolvidos em vários processos relacionados à resistência de plantas contra fitopatógenos como: resposta de hipersensibilidade, apoptose, estresse oxidativo, síntese e transporte de metabólitos antimicrobianos, percepção e transdução de sinal, metabolismo de lipídeos e degradação controlada de proteínas.

Como pode ser observado na Tabela 12, no primeiro grupo de genes relacionados à defesa vegetal, identificado no Híbrido de Timor após inoculação com $H$. vastatrix, encontram-se aqueles implicados no estresse oxidativo, na resposta de hipersensibilidade ou apoptose. Foram isolados clones codificadores de proteínas envolvidas nos mecanismos de proteção da célula vegetal contra os danos provocados pelo estresse oxidativo, como a anidrase carbônica, a glutationa redutase e as enzimas antioxidantes, ascorbato peroxidase e glutationa peroxidase, as quais, catalisam a redução de peróxido de hidrogênio ou peróxidos de lipídeos e hidroperóxidos orgânicos, minimizando os efeitos tóxicos desses compostos. Foi verificada, também, a presença de um clone codificador de cisteína protease (HT-HSS1-B04), envolvida na morte celular desencadeada por fitopatógenos e do clone, HT-HSS3-G07, codificador de uma proteína pertencente à família denominada "HIR" (reação de hipersensibilidade induzida), associada com a reação de hipersensibilidade, envolvendo a morte celular e a resistência contra patógenos (Tabela 12). A análise através do programa CD-Search do NCBI 
revelou, que as proteínas codificadas pelos clones HT-HSS4-A12 e HT-HSS02-F10, apresentaram, respectivamente, três e dois domínios conservados específicos de anidrase carbônica e de glutationa peroxidase. O clone HT-HSS01-B04 apresentou três domínios conservados específicos de cisteína protease, sendo que, dois destes são característicos da família papaína. O clone, HT-HSS3-G07, codificador da proteína HIR, apresentou quatro domínios característicos da superfamília PID, que engloba as proibitinas, estomatinas e as proteínas "HIR".

Foi detectado em cafeeiro Híbrido de Timor, um segundo grupo de genes codificadores de compostos antimicrobianos, como o inibidor de pectina metilesterase (PMEI), a enzima aspártico proteinase e os clones codificadores de proteínas relacionadas à patogênese, incluindo a $\beta$-1,3-glucanase e inibidores de cisteína proteinase, tipo cistatina (Tabela 13). Através do programa BlastX, foi possível verificar que o clone HT-HSS1-F02 apresentou maior similaridade com uma proteína de $N$. tabacum denominada "Homólogo DC1.2" e com sequiências de inibidores de pectina metilesterases de outras plantas, depositadas no GenBank. A análise através do CDSearch/NCBI revelou que a proteína codificada pelo gene de cafeeiro, clone HT-HSS3H06, apresentou, também, dois domínios conservados característicos de aspartil protease. Os dois clones codificadores de inibidores de cisteína proteinase, HT-HSS3D04 e HT-HSS3-A01 apresentaram, cada um, dois e três domínios de cistatina, respectivamente, enquanto que o clone HT-HSS1-F02 possui o domínio PMEI, especifico de proteínas inibidoras de pectina metilesterases e invertases. Para a $\beta-1,3-$ glucanase codificada pelo clone, HT-HSS1-G05, foram encontrados um domínio de exo$\beta$-1,3-glucanase e um característico de glicosil hidrolases da família 17. A partir da seqüência de nucleotídeos determinada para o clone de cDNA HT-HSS1-G05, foi possível desenhar os primers específicos senso e anti-senso para a obtenção da seqüência completa do gene de cafeeiro Híbrido de Timor codificador de $\beta$-1,3glucanase, induzido nas condições estudadas. 
Tabela 12. Genes de cafeeiro Híbrido de Timor inoculado com Hemileia vastatrix, envolvidos no estresse oxidativo, resposta de hipersensibilidade e/ou apoptose.

\begin{tabular}{|c|c|c|c|}
\hline Função ( $n^{\circ}$ de acesso) ${ }^{1}$ & Clone $^{2}$ & Valor de $\mathrm{E}^{3}$ & $\begin{array}{l}\text { Expressão } \\
\text { diferencial do } \\
\text { gene }^{4}\end{array}$ \\
\hline $\begin{array}{l}\text { Anidrase carbônica [Nicotiana } \\
\text { tabacum] AAL51055 }\end{array}$ & HT-HSS4-A12 & $5 e-64$ & + \\
\hline $\begin{array}{l}\text { Ascorbato peroxidase [Nicotiana } \\
\text { tabacum] BAA78552 }\end{array}$ & HT-HSS1-E04 & $5 e-17$ & + \\
\hline Catalase [Soldanella alpina] O24339 & HT-HSS1-A01 & $4 e-71$ & - \\
\hline Catalase [Vitis vinifera] AAL83720 & HT-HSS3-A10 & $1 e-68$ & - \\
\hline $\begin{array}{l}\text { Cisteína protease [Ipomoea batatas] } \\
\text { AAK48495 }\end{array}$ & HT-HSS1-B04 & $1 e-54$ & + \\
\hline $\begin{array}{l}\text { Glutationa peroxidase [Nicotiana } \\
\text { sylvestris] P30708 }\end{array}$ & HT-HSS2-F10 & $2 e-21$ & + \\
\hline $\begin{array}{l}\text { Glutationa reductase [Betula pendula] } \\
\text { CAB66332 }\end{array}$ & HT-HSS2-H10 & $1 e-66$ & + \\
\hline $\begin{array}{l}\text { Proteína de resposta induzida por } \\
\text { hipersensibilidade (HIR) [Oryza } \\
\text { sativa] AAK54610 }\end{array}$ & HT-HSS3-G07 & $1 e-76$ & + \\
\hline
\end{tabular}

${ }^{1}$ A função de cada gene foi detectada por comparação com seqüências homólogas presentes no NCBI, utilizando-se o programa BlastX. A função associada à seqüência de maior homologia detectada para cada clone de cDNA de cafeeiro, foi relacionada juntamente com a respectiva origem (espécie do organismo e número de acesso do GenBank). ${ }^{2}$ Genes isolados por hibridização subtrativa por supressão, a partir de mRNAs de cafeeiro Híbrido de Timor inoculado com $H$. vastatrix. ${ }^{3} \mathrm{O}$ valor de $\mathrm{E}$ foi utilizado para indicar a significância da similaridade de seqüência encontrada para cada gene. ${ }^{4}$ A confirmação da expressão de cada gene isolado de planta inoculada foi determinada utilizando-se a técnica da seleção diferencial. +: gene induzido; -: gene não induzido. 
Tabela 13. Genes isolados de cafeeiro Híbrido de Timor inoculado com Hemileia vastatrix, codificadores de compostos antimicrobianos.

\begin{tabular}{|c|c|c|c|}
\hline Função (nº de acesso) ${ }^{1}$ & Clone $^{2}$ & Valor de $\mathrm{E}^{3}$ & $\begin{array}{l}\text { Expressão } \\
\text { diferencial do } \\
\text { gene }^{4}\end{array}$ \\
\hline $\begin{array}{l}\text { Aspártico proteinase [Lycopersicon } \\
\text { esculentum] S71591 }\end{array}$ & HT-HSS3-H06 & $7 e-93$ & + \\
\hline $\begin{array}{l}\beta-1,3-\text {-Glucanase [Vitis vinifera] } \\
\text { AAF44667 }\end{array}$ & HT-HSS1-G05 & $1 e-58$ & + \\
\hline $\begin{array}{l}\text { Inibidor de cisteína proteinase (tipo } \\
\text { cistatina) [Arabidopsis thaliana] } \\
\text { NP193383 }\end{array}$ & HT-HSS3-A01 & $8 \mathrm{e}-06$ & + \\
\hline $\begin{array}{l}\text { Inibidor de cisteína proteinase (tipo } \\
\text { cistatina) [Arabidopsis thaliana] } \\
\text { AAO22603 }\end{array}$ & HT-HSS3-D04 & $2 \mathrm{e}-06$ & + \\
\hline $\begin{array}{l}\text { Inibidor de pectina } \\
\text { metilesterase/invertase (PMEI) } \\
\text { (homólogo DC1.2) [Nicotiana } \\
\text { tabacum] BAA95794 }\end{array}$ & HT-HSS1-F02 & $1 \mathrm{e}-33$ & + \\
\hline
\end{tabular}

${ }^{1}$ A função de cada gene foi detectada por comparação com seqüências homólogas presentes no NCBI, utilizando-se o programa BlastX. A função associada à seqüência de maior homologia detectada para cada clone de cDNA de cafeeiro, foi relacionada juntamente com a respectiva origem (espécie do organismo e número de acesso do GenBank). ${ }^{2}$ Genes isolados por hibridização subtrativa por supressão, a partir de mRNAs de cafeeiro Híbrido de Timor inoculado com $H$. vastatrix. ${ }^{3} \mathrm{O}$ valor de $\mathrm{E}$ foi utilizado para indicar a significância da similaridade de seqüência encontrada para cada gene. ${ }^{4}$ A confirmação da expressão de cada gene isolado de planta inoculada foi determinada utilizando-se a técnica da seleção diferencial. +: gene induzido; -: gene não induzido.

Como pode ser observado na Tabela 14, o terceiro grupo de genes relacionado à defesa vegetal isolado de cafeeiro inoculado com $H$. vastatrix, está envolvido na síntese e transporte de metabólitos antimicrobianos. Foram isolados dois clones de genes codificadores da enzima CAD, envolvida na síntese de lignina e um clone codificador de isoflavona redutase implicada na síntese de fitoalexinas isoflavonóides (pterocarpanos). 
Puderam ser isolados outros genes implicados na síntese de metabólitos secundários antimicrobianos, como aqueles que apresentaram similaridade com a (S)-Nmetilcoclaurina 3'-hidroxilase e a reticulina oxidase (enzima formadora da ponte de berberina), enzimas envolvidas na síntese de alcalóides, resultando na formação de (S)reticulina e de berberina, respectivamente. Quanto ao transporte de metabólitos antimicrobianos, foram identificados nove clones de cDNAs codificadores da proteína transportadora ABC tipo PDR ("pleiotropic drug resistance like protein”), envolvida na absorção intracelular e transporte de citotoxinas e na secreção de compostos do metabolismo secundário implicados na defesa vegetal, como terpenos antifúngicos (Tabela 14). Além destes, o clone HT-HSS1-A03, foi análogo ao transportador ABC, tipo ABC1 de $A$. thaliana, não relacionado aos demais, envolvido no transporte de compostos associados à fotossíntese. A análise através do programa CD-Search do NCBI revelou, que os clones isolados de cafeeiro, codificadores da proteína transportadora ABC, apresentaram, também, os domínios conservados da superfamília de transportadores ABC ou da subfamília PDR. Entretanto, para o clone HT-HSS4-D03, além destes domínios, foram encontrados 23 domínios adicionais relacionados ao transporte de diferentes substratos como, sideróforos, íons de metais pesados, lipídeos, açúcares, além do domínio SalX, característico do sistema de transporte de peptídeos antimicrobianos. Os clones de cDNA de genes codificadores de CAD e da Nmetilcoclaurina 3’-hidroxilase apresentaram domínios de álcool desidrogenase classe V e de citocromo P450, respectivamente, enquanto que, para o clone HT-HSS4-C11 foi encontrado um domínio específico de isoflavona redutase. 
Tabela 14. Genes de cafeeiro Híbrido de Timor inoculado com Hemileia vastatrix, envolvidos na síntese de fitoalexinas, fenóis, alcalóides e/ou lignina e no transporte de compostos secundários antimicrobianos.

\begin{tabular}{|c|c|c|c|}
\hline Função (nº de acesso) ${ }^{1}$ & Clone $^{2}$ & Valor de $\mathrm{E}^{3}$ & $\begin{array}{l}\text { Expressão } \\
\text { diferencial do }_{\text {gene }^{4}}\end{array}$ \\
\hline $\begin{array}{l}\text { Cinamil álcool desidrogenase (CAD) } \\
\text { [Brassica napus] AAF23413 }\end{array}$ & HT-HSS4-B06 & 3e-19 & + \\
\hline $\begin{array}{l}\text { Cinamil álcool desidrogenase (CAD) } \\
\text { [Malus domestica] T16995 }\end{array}$ & HT-HSS4-G01 & $6 e-60$ & + \\
\hline $\begin{array}{l}\text { Isoflavona redutase [Citrus paradisi] } \\
\text { CAA73220 }\end{array}$ & HT-HSS4-C11 & $7 e-19$ & + \\
\hline $\begin{array}{l}\text { (S)-N-metilcoclaurina 3'-hidroxilase } \\
\text { [Eschscholzia californica] T07964 }\end{array}$ & HT-HSS2-A08 & $2 \mathrm{e}-26$ & + \\
\hline $\begin{array}{l}\text { Transportador ABC tipo ABC1 } \\
\text { [Arabidopsis thaliana] NP194867 }\end{array}$ & HT-HSS1-A03 & $5 e-29$ & + \\
\hline $\begin{array}{l}\text { Proteína Transportadora ABC tipo PDR } \\
\text { (ativada por elicitor) [Nicotiana } \\
\text { tabacum] BAB92011 }\end{array}$ & $\begin{array}{l}\text { HT-HSS2-B04; } \\
\text { HT-HSS3-A05, } \\
\text { D08 e E08 }\end{array}$ & 2e-87 & + \\
\hline $\begin{array}{l}\text { Proteína transportadora ABC tipo } \\
\text { PDR1 [Oryza sativa] BAB21273 }\end{array}$ & HT-HSS1-G11 & $1 \mathrm{e}-38$ & + \\
\hline $\begin{array}{l}\text { Proteína transportadora ABC tipo PDR } \\
\text { [Oryza sativa] CAD59570 }\end{array}$ & $\begin{array}{l}\text { HT-HSS3-C10; } \\
\text { HT-HSS4-D03 }\end{array}$ & $9 e-98$ & + \\
\hline $\begin{array}{l}\text { Proteína transportadora ABC tipo } \\
\text { PDR5 [Spirodela polyrrhiza] } \\
\text { CAA94437 }\end{array}$ & $\begin{array}{l}\text { HT-HSS2-G03 e } \\
\text { H08 }\end{array}$ & 3e-39 & + \\
\hline $\begin{array}{l}\text { Reticulina oxidase [Arabidopsis } \\
\text { thaliana] T10626 }\end{array}$ & HT-HSS4-B07 & $2 \mathrm{e}-27$ & + \\
\hline
\end{tabular}

${ }^{1}$ A função de cada gene foi detectada por comparação com sequiências homólogas presentes no NCBI, utilizando-se o programa BlastX. A função associada à seqüência de maior homologia detectada para cada clone de cDNA de cafeeiro, foi relacionada juntamente com a respectiva origem (espécie do organismo e número de acesso do GenBank). ${ }^{2}$ Genes isolados por hibridização subtrativa por supressão, a partir de mRNAs de cafeeiro Híbrido de Timor inoculado com $H$. vastatrix. ${ }^{3} \mathrm{O}$ valor de E foi utilizado para indicar a significância da similaridade de seqüência encontrada para cada gene. ${ }^{4}$ A confirmação da expressão de cada gene isolado de planta inoculada foi determinada utilizando-se a técnica da seleção diferencial. +: gene induzido; -: gene não induzido. 
No quarto grupo de genes isolados de cafeeiro Híbrido de Timor inoculado com $H$. vastatrix, encontram-se aqueles implicados na síntese de compostos de baixo peso molecular, como os reguladores vegetais, etileno e ácido jasmônico, ou na produção de outros compostos intermediários secundários, que apresentam uma função sinalizadora de respostas de resistência (Tabela 15). Foi possível isolar de cafeeiro, um clone de gene codificador da enzima S-adenosil-L-metionina sintetase (SAM sintetase, ciclo de Yang), que pode levar à síntese de etileno ou de poliaminas e um clone codificador de ACC oxidase, enzima da biossíntese de etileno. Foram isolados, ainda, genes codificadores de fosfolipase e de lipoxigenase, enzimas envolvidas na produção de peróxidos de lipídeos e na síntese de ácido jasmônico (Tabela 15). A análise através do programa BlastX revelou, também, que o clone HT-HSS4-G06, codificador de fosfolipase, apresentou similaridade com lisofosfolipases (fosfolipases A) de A. thaliana e de O. sativa, enzima envolvida na produção de lisofosfolipídeos e de ácidos graxos livres, como o ácido linolênico, precursor da via de biossíntese de ácido jasmônico e substrato da lipoxigenase. A análise através do programa CD-Search do NCBI revelou, que as proteínas codificadas pelos genes isolados de cafeeiro, clones HT-HSS3-D06, HTHSS4-G06 e HT-HSS1-C08 apresentaram, também, domínios conservados específicos de SAM-sintetase (quatro domínios), lisofosfolipase (dois domínios) e de lipoxigenase (um domínio), respectivamente.

Como pode ser observado na Tabela 16, foi possível isolar de cafeeiro Híbrido de Timor inoculado com $H$. vastatrix, um quinto grupo de genes envolvidos na percepção e transdução de sinal. Entre estes, os clones de genes, HT-HSS3-E07 e HTHSS1-A04, apresentaram similaridade com tipos distintos de proteínas de ligação e hidrólise do GTP, a proteína G composta de três sub-unidades e uma GTPase monomérica da família “Rab”, respectivamente. Por outro lado, o clone HT-HSS3-G02 apresentou similaridade com uma proteína capaz de se ligar à calmodulina, a qual apresenta sítios de ligação para o íon cálcio. Como pode ser observado na Tabela 16, foram detectados sete clones de genes codificadores de quinases que modificam, por fosforilação, proteínas alvo nos resíduos específicos de serina e treonina ou tirosina, sendo que o clone HT-HSS3-B07, apresentou similaridade com uma quinase tipo CIPK, 
capaz de interagir com a proteína calcineurina B sensora de cálcio (CBL). Além da proteína CIPK, foram detectados outros tipos distintos de quinases codificadas pelos clones HT-HSS2-C06 e HT-HSS2-G11, os quais apresentaram, respectivamente, similaridade com uma proteína tipo CDPK com domínio de calmodulina, regulada por cálcio e com a proteína WIPK de $N$. tabacum, uma quinase ativada por agentes mitogênicos, MAP-quinase, responsável pela regulação direta de fatores de transcrição. A análise através do programa CD-Search do NCBI revelou, que as proteínas codificadas por estes clones de genes, apresentaram, também, vários domínios conservados de serina/treonina ou tirosina quinases, sendo que o clone HT-HSS3-B07, possui o domínio NAF, necessário e suficiente para mediar a interação com as proteínas CBLs sensoras de cálcio e presente nas proteínas CIPKs. Foram isolados cinco clones de genes codificadores de proteínas quinases tipo receptoras (RLKs), as quais estão relacionadas com a transmissão de sinais através da membrana plasmática. Entre estes genes, o clone HT-HSS3-D02, apresentou similaridade com uma RLK da família do domínio-S (glicoproteínas do locus S), quinases que possuem um domínio extracelular similar às glicoproteínas do locus S do gênero Brassica. Através da análise pelo CDSearch do NCBI, foi possível verificar, também, a presença de domínios de serina/treonina ou tirosina quinases nas proteínas codificadas por esses genes e de domínio da família das glicoproteínas S-locus, apenas nos clones, HT-HSS1-F09, HTHSS3-D02, HT-HSSS3-F03 e HT-HSS3-G03. Os clones, HT-HSSS3-F03 e -G03, apresentaram ainda, dois domínios PAN, característico da porção extracelular de RLKs de plantas, que possui uma função de ligação à proteínas e/ou carboidratos (CDSearch/NCBI). Foram detectados, também, seis clones de genes, que apresentaram similaridade com seqüências do GenBank, codificadoras de proteínas de resistência, envolvidas nos mecanismos de reconhecimento entre planta e fitopatógenos, como aquelas contendo repetições ricas em leucina (LRR) e/ou sítios de ligação à nucleotídeos (NBS). Por outro lado, o clone HT-HSS4-E09, apresentou similaridade com a proteína de membrana da família Mlo, a qual não possui os motivos estruturais presentes em proteínas de resistência (Tabela 16). A análise através do NCBI-CD-Search revelou, que as proteínas de resistência codificadas pelos genes isolados de cafeeiro, clones HT- 
HSS1-G06, HT-HSS1-D10 e HT-HSS4-E09, apresentaram, também, três ou dois domínios LRR e um domínio especifico da família Mlo, respectivamente. Como pode ser observado na Tabela 16, além dos genes já mencionados, foram isolados de Híbrido de Timor, clones de cDNA codificadores de um fator de transcrição da família bZIP, de uma proteína com repetições de anquirina, de uma proteína receptora com capacidade de ligação à moléculas ativadoras de respostas de defesa, tipo $\beta$-glucana e da proteína sintaxina SNAP33, pertencente a família de receptores implicados no transporte intracelular de vesículas. A análise através do programa CD-Search do NCBI revelou que o clone HT-HSS4-H03, apresentou, também, um domínio SNAP-25 característico da proteína SNAP-25 associada com o sinaptosomo, componente do complexo SNARE. Foi verificado, também, que o clone HT-HSS1-G01 apresentou três domínios conservados de repetições de anquirina (CD-Search/NCBI). O clone HT-HSS3-E09 que apresentou maior similaridade com um receptor de elicitor $\beta$-glucana isolado de Brassica napus, possui três domínios, sendo um deles característico de glicosil hidrolases da família 81 (pfam03639), um de endo-1,3- $\beta$-glucanase (KOG2254) e o outro referente às glicosil hidrolases (COG5498, ACF2) (CD-Search/NCBI). O clone HT-HSS1-G01 apresentou três domínios iguais conservados de repetições de anquirina (cd00204, ANK), que mediam interações entre proteínas. 
Tabela 15. Genes isolados de cafeeiro Híbrido de Timor inoculado com Hemileia vastatrix, envolvidos na síntese de compostos de baixo peso molecular com função sinalizadora de respostas de defesa.

\begin{tabular}{lccc}
\hline \multicolumn{1}{c}{ Função (n ${ }^{\circ}$ de acesso) ${ }^{1}$} & Clone $^{2}$ & Valor de E $^{3}$ & $\begin{array}{c}\text { Expressão } \\
\text { diferencial do } \\
\text { gene }^{4}\end{array}$ \\
\hline $\begin{array}{l}\text { 1-Aminociclopropano-1-carboxilato } \\
\text { oxidase 4 (ACC oxidase 4) } \\
\text { [Lycopersicon esculentum] P24157 }\end{array}$ & HT-HSS1-B09 & 2e-34 & + \\
$\begin{array}{l}\text { Fosfolipase [Arabidopsis thaliana] } \\
\text { AAL87258 }\end{array}$ & HT-HSS4-G06 & 3e-31 & + \\
$\begin{array}{l}\text { Lipoxigenase LX-3 [Solanum } \\
\text { tuberosum] T07775 }\end{array}$ & HT-HSS1-C08 & 2e-51 & + \\
$\begin{array}{l}\text { S-Adenosil-L-metionina sintetase 3 } \\
\text { [Catharanthus roseus] Q96553 }\end{array}$ & HT-HSS3-D06 & 2e-64 & + \\
\hline
\end{tabular}

${ }^{1}$ A função de cada gene foi detectada por comparação com seqüências homólogas presentes no NCBI, utilizando-se o programa BlastX. A função associada à seqüência de maior homologia detectada para cada clone de cDNA de cafeeiro, foi relacionada juntamente com a respectiva origem (espécie do organismo e número de acesso do GenBank). ${ }^{2}$ Genes isolados por hibridização subtrativa por supressão, a partir de mRNAs de cafeeiro Híbrido de Timor inoculado com $H$. vastatrix. ${ }^{3} \mathrm{O}$ valor de $\mathrm{E}$ foi utilizado para indicar a significância da similaridade de seqüência encontrada para cada gene. ${ }^{4}$ A confirmação da expressão de cada gene isolado de planta inoculada foi determinada utilizando-se a técnica da seleção diferencial. +: gene induzido; -: gene não induzido. 
Tabela 16. Genes de cafeeiro Híbrido de Timor inoculado com Hemileia vastatrix, envolvidos na percepção e transdução do sinal de resistência.

\begin{tabular}{|c|c|c|c|}
\hline Função (nº de acesso) ${ }^{1}$ & Clone $^{2}$ & Valor de $\mathrm{E}^{3}$ & $\begin{array}{l}\text { Expressão } \\
\text { diferencial do } \\
\text { gene }^{4}\end{array}$ \\
\hline $\begin{array}{l}\text { Fator de transcrição família bZIP } \\
\text { [Arabidopsis thaliana] NP564269 }\end{array}$ & HT-HSS1-B05 & $8 \mathrm{e}-07$ & + \\
\hline $\begin{array}{l}\text { Proteína de ligação à calmodulina 60-B } \\
\text { [Phaseolus vulgaris] AAN65368 }\end{array}$ & HT-HSS3-G02 & $1 e-14$ & + \\
\hline $\begin{array}{l}\text { Pequena proteína de ligação ao GTP } \\
\text { (RAB1C) [Lotus corniculatus] } \\
\text { CAA98160 }\end{array}$ & HT-HSS1-A04 & $7 e-48$ & + \\
\hline $\begin{array}{l}\text { Proteína G, extra grande, de ligação ao } \\
\text { GTP [Arabidopsis thaliana] NP195165 }\end{array}$ & HT-HSS3-E07 & 1e-17 & + \\
\hline $\begin{array}{l}\text { Proteína MLO [Arabidopsis thaliana] } \\
\text { T02582 }\end{array}$ & HT-HSS4-E09 & $2 \mathrm{e}-47$ & + \\
\hline $\begin{array}{l}\text { Proteína quinase [Arabidopsis thaliana] } \\
\text { NP176870 }\end{array}$ & HT-HSS1-D03 & 3e-07 & + \\
\hline $\begin{array}{l}\text { Proteína quinase [Arabidopsis thaliana] } \\
\text { NP177209 }\end{array}$ & HT-HSS2-A05 & $2 \mathrm{e}-43$ & + \\
\hline $\begin{array}{l}\text { Proteína quinase ativada por mitógeno } \\
\text { WIPK (MAP-quinase) [Nicotiana } \\
\text { tabacum] T03971 }\end{array}$ & HT-HSS2-G11 & 2e-54 & + \\
\hline $\begin{array}{l}\text { Proteína quinase dependente de } \\
\text { cálcio/calmodulina CaMK2 (CDPK) } \\
\text { [Nicotiana tabacum] AAL30819 }\end{array}$ & HT-HSS2-C06 & $4 \mathrm{e}-41$ & + \\
\hline $\begin{array}{l}\text { Proteína quinase tipo CIPK de interação } \\
\text { com proteína tipo calcineurina B (CBL) } \\
\text { [Arabidopsis thaliana] NP566580 }\end{array}$ & HT-HSS3-B07 & $9 e-30$ & + \\
\hline $\begin{array}{l}\text { Proteína serina/treonina quinase } \\
\text { [Spinacia oleracea] S42868 }\end{array}$ & $\begin{array}{l}\text { HT-HSS1-E06; } \\
\text { HT-HSS4-C03 }\end{array}$ & 3e-80 & + \\
\hline $\begin{array}{l}\text { Proteína quinase tipo receptora } \\
\text { [Arabidopsis thaliana] NP192429 }\end{array}$ & HT-HSS3-B11 & 3e-30 & + \\
\hline
\end{tabular}




\begin{tabular}{|c|c|c|c|}
\hline Função (nº de acesso) ${ }^{1}$ & Clone $^{2}$ & Valor de $\mathrm{E}^{3}$ & $\begin{array}{l}\text { Expressão } \\
\text { diferencial do } \\
\text { gene }^{4}\end{array}$ \\
\hline $\begin{array}{l}\text { Proteína quinase tipo receptora } \\
\text { [Arabidopsis thaliana] NP194459 }\end{array}$ & $\begin{array}{l}\text { HT-HSS3-F03 e } \\
\text { G03 }\end{array}$ & $1 \mathrm{e}-50$ & + \\
\hline $\begin{array}{l}\text { Proteína quinase tipo receptora (IRK1) } \\
\text { [Arabidopsis thaliana] NP176343 }\end{array}$ & HT-HSS1-F09 & 2e-11 & + \\
\hline $\begin{array}{l}\text { Proteina quinase tipo receptora S-locus } \\
\text { (família glicoproteína do locus S) } \\
\text { [Arabidopsis thaliana] NP176339 }\end{array}$ & HT-HSS3-D02 & 2e-10 & + \\
\hline $\begin{array}{l}\text { Proteína de resistência [Oryza sativa] } \\
\text { BAC99674 }\end{array}$ & HT-HSS4-A11 & $2 e-07$ & + \\
\hline $\begin{array}{l}\text { Proteína de resistência à doenças I2 } \\
\text { com repetições ricas em leucina [Oryza } \\
\text { sativa] BAB89710 }\end{array}$ & HT-HSS1-D10 & 2e-09 & + \\
\hline $\begin{array}{l}\text { Proteína de resistência à doenças rga2 } \\
\text { [Solanum bulbocastanum] AAP45188 }\end{array}$ & HT-HSS1-G06 & $2 e-13$ & + \\
\hline $\begin{array}{l}\text { Proteína de resistência N1-C (TIR- } \\
\text { NBS-LRR) [Linum usitatissimum] } \\
\text { CAC35329 }\end{array}$ & HT-HSS3-D09 & $9 e-04$ & + \\
\hline $\begin{array}{l}\text { Proteína NBS-LRR [Solanum acaule] } \\
\text { CAB56299 }\end{array}$ & HT-HSS4-B02 & $9 e-22$ & + \\
\hline $\begin{array}{l}\text { Proteína com repetições de anquirina } \\
\text { [Vitis aestivalis] AAQ96339 }\end{array}$ & HT-HSS1-G01 & 2e-58 & - \\
\hline $\begin{array}{l}\text { Receptor de elicitor beta-glucana } \\
\text { [Brassica napus] AAP42646 }\end{array}$ & HT-HSS3-E09 & $8 e-55$ & + \\
\hline $\begin{array}{l}\text { Sintaxina SNAP33 [Arabidopsis } \\
\text { thaliana] NP200929 }\end{array}$ & HT-HSS4-H03 & 3e-44 & + \\
\hline
\end{tabular}

${ }^{1}$ A função de cada gene foi detectada por comparação com seqüências homólogas presentes no NCBI, utilizando-se o programa BlastX. A função associada à seqüência de maior homologia detectada para cada clone de cDNA de cafeeiro, foi relacionada juntamente com a respectiva origem (espécie do organismo e número de acesso do GenBank). ${ }^{2}$ Genes isolados por hibridização subtrativa por supressão, a partir de mRNAs de cafeeiro Híbrido de Timor inoculado com $H$. vastatrix. ${ }^{3} \mathrm{O}$ valor de E foi utilizado para indicar a significância da similaridade de seqüência encontrada para cada gene. ${ }^{4}$ A confirmação da expressão de cada gene isolado de planta inoculada foi determinada utilizando-se a técnica da seleção diferencial. +: gene induzido; -: gene não induzido. 
Como pode ser observado na Tabela 17, um grupo de proteínas codificadas pelos clones de cDNA, isolados de cafeeiro Híbrido de Timor inoculado com $H$. vastatrix estão relacionadas com o metabolismo ou transporte de lipídeos. Quatro clones isolados apresentaram similaridade significativa com gene codificador da enzima acilCoA sintetase, envolvida na esterificação de ácidos graxos, um clone foi similar a acilCoA oxidase implicada na beta oxidação de ácidos graxos e um clone foi análogo à omega-6- ácido graxo desaturase, enzima da biosíntese de ácidos graxos poliinsaturados (Tabela 17). A análise através do NCBI-CD-Search revelou, que as proteínas codificadas pelos clones HT-HSS3-F06, HT-HSS4-E03, -GO7 e -G08, apresentaram, também, vários domínios de acil-coenzima A sintetases e de acil-CoA ligases de ácidos graxos de cadeia longa ou de acil-CoA sintetases de cadeia longa, transportadoras de ácido graxo.

Foi possível isolar de cafeeiro Híbrido de Timor inoculado com H. vastatrix, um grupo de genes implicados na degradação controlada de proteínas, mediada pelo complexo proteassomo/ubiquitina com a ação de ubiquitina ligases (Tabela 18). Três clones de cafeeiro apresentaram similaridade com as proteínas do complexo multicatalítico de proteinases, o proteassomo 26S, incluindo aquelas pertencentes à partícula 20S, realizadora da proteólise e à partícula 19S, unidade reguladora do proteassomo, que reconhece as proteínas alvo marcadas com ubiquitina, selecionadas para a degradação. Além destes, foram isolados genes codificadores de ubiquitinas e de enzima de conjugação com ubiquitina (Tabela 18). Os clones HT-HSS2-B03 e HTHSS3-H01 apresentaram, também, vários domínios conservados correspondentes à ubiquitina (NCBI/CD-Search). O mesmo foi observado para o clone HT-HSS4-G02, que apresentou um domínio especifico de ubiquitina-proteína ligase e para os clones, HTHSS1-G10, HT-HSS2-D09 e HT-HSS3-B03, que apresentaram, respectivamente, domínios das subunidades alfa e beta do proteassomo 20S e do complexo regulatório do proteassomo 26S (NCBI/CD-Search).

Além dos genes relacionados à resistência de plantas contra fitopatógenos (Tabelas 12, 13, 14, 15, 16, 17 e 18), foi verificado que 106 clones de cDNA apresentaram similaridade significativa com genes envolvidos na manutenção celular e desenvolvimento vegetal (Tabela 19). As funções encontradas para os genes isolados de 
cafeeiro Híbrido de Timor inoculado com $H$. vastatrix estão relacionadas a diversos processos, como por exemplo, fotossíntese, síntese protéica, dobramento e transporte de proteínas através da membrana celular, como as proteínas de choque térmico tipo chaperonas, divisão e crescimento celular, formação de meristema apical, vias ativadas por auxina, vias biosínteticas do metabolismo primário, como a glicólise, transporte de carboidratos, além de proteínas estruturais. Foram incluídos nesse grupo, alguns tipos de proteínas de estresse, como aquelas induzidas por desidratação.

Tabela 17. Genes de cafeeiro Híbrido de Timor inoculado com Hemileia vastatrix, envolvidos no metabolismo de lipídeos.

\begin{tabular}{|c|c|c|c|}
\hline Função (nº de acesso) ${ }^{1}$ & Clone $^{2}$ & Valor de $\mathrm{E}^{3}$ & $\begin{array}{l}\text { Expressão } \\
\text { diferencial do } \\
\text { gene }^{4}\end{array}$ \\
\hline $\begin{array}{l}\text { Acil-CoA oxidase [Glycine max] } \\
\text { AAL } 01888\end{array}$ & HT-HSS1-C03 & $7 e-37$ & + \\
\hline $\begin{array}{l}\text { Acil-CoA sintetase [Capsicum } \\
\text { annuum] AAL } 29212\end{array}$ & $\begin{array}{c}\text { HT-HSS3-F06; } \\
\text { HT-HSS4-E03, } \\
\text { G07 e G08 }\end{array}$ & 2e-76 & + \\
\hline $\begin{array}{l}\text { Omega-6 ácido graxo desaturase } \\
\text { [Brassica napus] P48627 }\end{array}$ & HT-HSS4-A10 & $4 e-38$ & + \\
\hline
\end{tabular}

${ }^{1}$ A função de cada gene foi detectada por comparação com seqüências homólogas presentes no NCBI, utilizando-se o programa BlastX. A função associada à seqüência de maior homologia detectada para cada clone de cDNA de cafeeiro, foi relacionada juntamente com a respectiva origem (espécie do organismo e número de acesso do GenBank). ${ }^{2}$ Genes isolados por hibridização subtrativa por supressão, a partir de mRNAs de cafeeiro Híbrido de Timor inoculado com $H$. vastatrix. ${ }^{3} \mathrm{O}$ valor de $\mathrm{E}$ foi utilizado para indicar a significância da similaridade de seqüência encontrada para cada gene. ${ }^{4}$ A confirmação da expressão de cada gene isolado de planta inoculada foi determinada utilizando-se a técnica da seleção diferencial. +: gene induzido; -: gene não induzido. 
Tabela 18. Genes de cafeeiro Híbrido de Timor inoculado com Hemileia vastatrix, envolvidos na degradação controlada de proteínas.

\begin{tabular}{|c|c|c|c|}
\hline Função ( $n^{\circ}$ de acesso) ${ }^{1}$ & Clones $^{2}$ & Valor de $\mathrm{E}^{3}$ & $\begin{array}{c}\text { Expressão } \\
\text { diferencial do } \\
\text { gene }^{4}\end{array}$ \\
\hline $\begin{array}{l}\text { Enzima de conjugação com } \\
\text { ubiquitina UBC10 (ubiquitina- } \\
\text { proteína ligase) [Arabidopsis thaliana] } \\
\text { NP568788 }\end{array}$ & HT-HSS4-G02 & 2e-05 & + \\
\hline $\begin{array}{l}\text { Subunidade reguladora do } \\
\text { proteassomo 26S [Arabidopsis } \\
\text { thaliana] NP181528 }\end{array}$ & HT-HSS3-B03 & $4 e-81$ & + \\
\hline $\begin{array}{l}\text { Subunidade beta do Proteassomo } \\
\text { 20S (PBA1) [Arabidopsis thaliana] } \\
\text { NP194858 }\end{array}$ & HT-HSS1-G10 & $7 e-40$ & + \\
\hline $\begin{array}{l}\text { Subunidade alfa } 3 \text { do Proteassomo } \\
\text { 20S [Petunia hybrida] O82530 }\end{array}$ & HT-HSS2-D09 & $2 e-46$ & + \\
\hline $\begin{array}{l}\text { Ubiquitina [Solanum tuberosum] } \\
\text { S42643 }\end{array}$ & HT-HSS2-B03 & $1 e-23$ & + \\
\hline $\begin{array}{l}\text { Poliubiquitina UBQ11 [Arabidopsis } \\
\text { thaliana] NP567286 }\end{array}$ & HT-HSS3-H01 & $1 e-88$ & + \\
\hline $\begin{array}{l}\text { Ubiquitina [Arabidopsis thaliana] } \\
\text { JQ1728 }\end{array}$ & HT-HSS4-E11 & $1 e-11$ & - \\
\hline
\end{tabular}

${ }^{1}$ A função de cada gene foi detectada por comparação com seqüências homólogas presentes no NCBI, utilizando-se o programa BlastX. A função associada à seqüência de maior homologia detectada para cada clone de cDNA de cafeeiro, foi relacionada juntamente com a respectiva origem (espécie do organismo e número de acesso do GenBank). ${ }^{2}$ Genes isolados por hibridização subtrativa por supressão, a partir de mRNAs de cafeeiro Híbrido de Timor inoculado com $H$. vastatrix. ${ }^{3} \mathrm{O}$ valor de $\mathrm{E}$ foi utilizado para indicar a significância da similaridade de seqüência encontrada para cada gene. ${ }^{4}$ A confirmação da expressão de cada gene isolado de planta inoculada foi determinada utilizando-se a técnica da seleção diferencial. +: gene induzido; -: gene não induzido. 
Tabela 19. Genes de cafeeiro Híbrido de Timor inoculado com Hemileia vastatrix, apresentando funções relacionadas à manutenção celular e desenvolvimento vegetal.

\begin{tabular}{|c|c|c|c|}
\hline Função (nº de acesso) ${ }^{1}$ & Clone $^{2}$ & Valor de $\mathrm{E}^{3}$ & $\begin{array}{l}\text { Expressão } \\
\text { diferencial do } \\
\text { gene }^{4}\end{array}$ \\
\hline $\begin{array}{l}\text { Acetilornitina aminotransferase [Alnus } \\
\text { glutinosa] O04866 }\end{array}$ & HT-HSS4-F12 & 3e-66 & + \\
\hline $\begin{array}{l}\text { Actina [Gossypium hirsutum] } \\
\text { AAP73450 }\end{array}$ & HT-HSS2-C04 & 1e-35 & + \\
\hline $\begin{array}{l}\text { Alanina aminotransferase [Oryza } \\
\text { sativa] AAO84040 }\end{array}$ & HT-HSS1-F03 & $7 e-72$ & + \\
\hline $\begin{array}{l}\text { Alanil-tRNA sintetase [Oryza sativa] } \\
\text { AAK70636 }\end{array}$ & HT-HSS1-G07 & 3e-65 & + \\
\hline $\begin{array}{l}\text { Aldoceto redutase [Arabidopsis } \\
\text { thaliana] NP564762 }\end{array}$ & HT-HSS2-G02 & $6 e-22$ & - \\
\hline $\begin{array}{l}\text { Alfa-amilase [Arabidopsis thaliana] } \\
\text { E96720 }\end{array}$ & HT-HSS3-C06 & $1 \mathrm{e}-90$ & + \\
\hline $\begin{array}{l}\text { Aminotransferase de aminoácido de } \\
\text { cadeia ramificada [Solanum tuberosum] } \\
\text { AAF07192 }\end{array}$ & HT-HSS1-H09 & 5e-36 & + \\
\hline $\begin{array}{l}\text { Apoproteína (CP-47) do fotosistema II } \\
\text { (PSII, clorofila A) [Oenothera } \\
\text { argillicola] P19819 }\end{array}$ & HT-HSS3-G10 & 4e-48 & - \\
\hline $\begin{array}{l}\text { Apoproteína do fotosistema II (PSII, } \\
\text { clorofila A) [Pisum sativum] 1612384A }\end{array}$ & HT-HSS1-E11 & $1 \mathrm{e}-30$ & - \\
\hline $\begin{array}{l}\text { ATPase [Arabidopsis thaliana] } \\
\text { NP187646 }\end{array}$ & HT-HSS1-A12 & 3e-20 & + \\
\hline $\begin{array}{l}\text { Asparagina sintetase [Securigera } \\
\text { parviflora] AAO38524 }\end{array}$ & HT-HSS4-E12 & 3e-76 & + \\
\hline $\begin{array}{l}\text { Centro de reação do fotosistema I (PSI- } \\
\text { F, Subunidade III) [Nicotiana tabacum] } \\
\text { AAP03872 }\end{array}$ & HT-HSS4-E10 & $9 e-39$ & + \\
\hline
\end{tabular}




\begin{tabular}{|c|c|c|c|}
\hline Função (nº de acesso) ${ }^{1}$ & Clone $^{2}$ & Valor de $\mathrm{E}^{3}$ & $\begin{array}{l}\text { Expressão } \\
\text { diferencial do } \\
\text { gene }^{4}\end{array}$ \\
\hline $\begin{array}{l}\text { Centro de reação do fotosistema I (PSI, } \\
\text { Subunidade IV) (PSI-E ) [Spinacia } \\
\text { oleracea] P12354 }\end{array}$ & HT-HSS1-F07 & 3e-19 & - \\
\hline $\begin{array}{l}\text { Ciclofilina [Euphorbia esula] } \\
\text { AAF65770 }\end{array}$ & HT-HSS1-E09 & $7 e-11$ & + \\
\hline $\begin{array}{l}\text { Cistationina gama-sintase [Solanum } \\
\text { tuberosum] AAF74982 }\end{array}$ & HT-HSS4-G04 & $1 e-56$ & + \\
\hline $\begin{array}{l}\text { Citocromo b6 (gene PetB ) [Zea mays] } \\
\text { AAB29194 }\end{array}$ & HT-HSS3-E12 & $1 e-60$ & - \\
\hline $\begin{array}{l}\text { Citocromo P450 (metaloproteína) } \\
\text { [Helianthus tuberosus] T10896 }\end{array}$ & HT-HSS1-E10 & $6 e-46$ & + \\
\hline $\begin{array}{l}\text { Citocromo P450 [Arabidopsis thaliana] } \\
\text { B96691 }\end{array}$ & HT-HSS1-F12 & $5 e-43$ & + \\
\hline $\begin{array}{l}\text { Citocromo P450 [Arabidopsis thaliana] } \\
\text { NP851136 }\end{array}$ & HT-HSS1-H07 & $6 e-33$ & + \\
\hline $\begin{array}{l}\text { Citocromo P450 [Arabidopsis thaliana] } \\
\text { T04444 }\end{array}$ & HT-HSS4-A03 & $4 e-51$ & + \\
\hline $\begin{array}{l}\text { Cobre amino oxidase [Arabidopsis } \\
\text { thaliana] NP181777 }\end{array}$ & HT-HSS1-A06 & $8 e-33$ & - \\
\hline $\begin{array}{l}\text { Exonuclease [Arabidopsis thaliana] } \\
\text { NP850090 }\end{array}$ & HT-HSS3-G06 & $3 e-29$ & + \\
\hline $\begin{array}{l}\text { Fator de elongação de translação EF-G } \\
\text { [Glycine max] CAA50573 }\end{array}$ & HT-HSS1-G12 & $4 e-62$ & + \\
\hline $\begin{array}{l}\text { Fator de elongação de translação } \\
\text { [Nicotiana tabacum] T03718 }\end{array}$ & HT-HSS4-E07 & $8 e-87$ & + \\
\hline $\begin{array}{l}\text { Fator de iniciação de translação de } \\
\text { proteína (SUI1) [Coffea arabica] } \\
\text { CAD58628 }\end{array}$ & HT-HSS1-A08 & $5 e-14$ & + \\
\hline $\begin{array}{l}\text { Fator de transcrição da família GRAS } \\
\text { [Oryza sativa] BAB90355 }\end{array}$ & HT-HSS4-D11 & 9e-71 & + \\
\hline $\begin{array}{l}\text { Fosfoenolpiruvato carboxiquinase } \\
\text { [Cucumis sativus] P42066 }\end{array}$ & HT-HSS4-C01 & $1 e-64$ & + \\
\hline
\end{tabular}




\begin{tabular}{|c|c|c|c|}
\hline Função (nº de acesso) ${ }^{1}$ & Clone $^{2}$ & Valor de $\mathrm{E}^{3}$ & $\begin{array}{l}\text { Expressão } \\
\text { diferencial do } \\
\text { gene }^{4}\end{array}$ \\
\hline $\begin{array}{l}\text { Fosfoesterase tipo calcineurina } \\
\text { [Arabidopsis thaliana] NP172830 }\end{array}$ & HT-HSS3-H09 & 9e-92 & + \\
\hline $\begin{array}{l}\text { Fosfofrutoquinase [Arabidopsis } \\
\text { thaliana] NP195010 }\end{array}$ & HT-HSS2-B12 & $7 e-35$ & + \\
\hline $\begin{array}{l}\text { Glicogenina glicosiltransferase } \\
\text { [Arabidopsis thaliana] NP197349 }\end{array}$ & HT-HSS1-D11 & $6 e-35$ & + \\
\hline $\begin{array}{l}\text { Glicolato oxidase [Mesembryanthemum } \\
\text { crystallinum] AAB } 40396\end{array}$ & HT-HSS2-B02 & $6 e-44$ & - \\
\hline $\begin{array}{l}\text { Glicosil hidrolase família } 14 \text { (beta- } \\
\text { amilase) [Arabidopsis thaliana] } \\
\text { NP189034 }\end{array}$ & $\begin{array}{l}\text { HT-HSS2-E03, } \\
\text { HT-HSS4-G09 }\end{array}$ & 5e-83 & + \\
\hline $\begin{array}{l}\text { Glicosil hidrolase família } 38 \text { (alfa } \\
\text { manosidase) [Arabidopsis thaliana] } \\
\text { NP189306 }\end{array}$ & HT-HSS3-B12 & 2e-69 & - \\
\hline $\begin{array}{l}\text { Glucose-6-fosfate 1-desidrogenase } \\
\text { [Solanum tuberosum] Q43839 }\end{array}$ & HT-HSS2-C08 & $4 e-45$ & + \\
\hline $\begin{array}{l}\text { Glucose-1-fosfato adenililtransferase } \\
\text { [Lycopersicon esculentum] T07674 }\end{array}$ & HT-HSS2-F06 & 3e-35 & + \\
\hline $\begin{array}{l}\text { Glutamato sintase dependente de } \\
\text { ferredoxina [Spinacia oleracea] } \\
\text { Q43155 }\end{array}$ & HT-HSS3-B08 & 3e-57 & + \\
\hline $\begin{array}{l}\text { Glutaredoxina [Arabidopsis thaliana] } \\
\text { NP191854 }\end{array}$ & HT-HSS1-C04 & $2 \mathrm{e}-41$ & + \\
\hline $\begin{array}{l}\text { Hidrolase da superfamília alfa/beta } \\
\text { (aciltransferase) [Arabidopsis thaliana] } \\
\text { NP195463 }\end{array}$ & HT-HSS3-C01 & $3 e-70$ & + \\
\hline $\begin{array}{l}\text { Limoneno ciclase [Arabidopsis } \\
\text { thaliana] G71434 }\end{array}$ & HT-HSS3-C02 & $6 e-36$ & + \\
\hline $\begin{array}{l}\text { Malato desidrogenase [Glycine } \max \text { ] } \\
\text { AAC37464 }\end{array}$ & HT-HSS1-F06 & $5 e-64$ & - \\
\hline $\begin{array}{l}\text { Metalotioneína [Citrus unshiu] } \\
\text { BAA31562 }\end{array}$ & $\begin{array}{l}\text { HT-HSS3-G12; } \\
\text { HT-HSS4-B10, } \\
\text {-E08 e -F06 }\end{array}$ & 3e-22 & - \\
\hline
\end{tabular}




\begin{tabular}{|c|c|c|c|}
\hline Função (nº de acesso) ${ }^{1}$ & Clone $^{2}$ & Valor de $\mathrm{E}^{3}$ & $\begin{array}{l}\text { Expressão } \\
\text { diferencial do } \\
\text { gene }^{4}\end{array}$ \\
\hline $\begin{array}{l}\text { Metalotioneína [Mimulus guttatus] } \\
\text { A34131 }\end{array}$ & HT-HSS2-E04 & $1 \mathrm{e}-18$ & - \\
\hline $\begin{array}{l}\text { Monoxigenase contendo flavina (FMO) } \\
\text { [Arabidopsis thaliana] NP173564 }\end{array}$ & HT-HSS4-E04 & 3e-30 & + \\
\hline $\begin{array}{l}\text { NADPH-ferrihemo proteína redutase } \\
\text { [Nicotiana tabacum] JE0230 }\end{array}$ & HT-HSS4-C10 & $9 e-62$ & + \\
\hline $\begin{array}{l}\text { Nitrato redutase [Glycine max] } \\
\text { AAD19790 }\end{array}$ & HT-HSS2-E01 & $2 e-36$ & - \\
\hline $\begin{array}{l}\text { Oxidoredutase [Arabidopsis thaliana] } \\
\text { NP178148 }\end{array}$ & HT-HSS1-A10 & $7 e-13$ & + \\
\hline $\begin{array}{l}\text { Oxidoreductase, família oxigenase } \\
\text { 2OG-Fe(II) (dioxigenase dependente de } \\
\text { 2-oxoglutarato) [Arabidopsis thaliana] } \\
\text { NP175689 }\end{array}$ & HT-HSS2-E06 & $1 \mathrm{e}-31$ & + \\
\hline $\begin{array}{l}\text { Oxidoreductase (dioxigenase } \\
\text { dependente de 2-oxoglutarato) } \\
\text { [Brassica oleracea] AAK95851 }\end{array}$ & HT-HSS2-C11 & 3e-13 & + \\
\hline $\begin{array}{l}\text { Plastoquinol-plastocianina redutase } \\
\text { [Zea mays] CAA29002 }\end{array}$ & HT-HSS3-B09 & $6 e-21$ & - \\
\hline $\begin{array}{l}\text { Proteína básica induzida por ferimento } \\
\text { [Phaseolus vulgaris] Q09020 }\end{array}$ & HT-HSS4-F03 & 1e-08 & + \\
\hline $\begin{array}{l}\text { Proteína biosintética de tiamina [Zea } \\
\text { mays] Q41739 }\end{array}$ & HT-HSS2-G12 & 3e-18 & + \\
\hline $\begin{array}{l}\text { Proteína CEO [Oryza sativa] } \\
\text { AAL58179 }\end{array}$ & HT-HSS3-D01 & $5 e-20$ & + \\
\hline $\begin{array}{l}\text { Proteína da família TUB [Arabidopsis } \\
\text { thaliana] H84920 }\end{array}$ & HT-HSS1-B03 & $4 e-58$ & + \\
\hline Proteína de choque térmico Hsp20 & HT-HSS3-C07 & $7 e-25$ & + \\
\hline [Arabidopsis thaliana] NP172134 & & & \\
\hline $\begin{array}{l}\text { Proteína de choque térmico DnaJ } \\
\text { [Arabidopsis thaliana] NP176181 }\end{array}$ & HT-HSS1-D08 & 3e-46 & + \\
\hline
\end{tabular}




\begin{tabular}{|c|c|c|c|}
\hline Função (nº de acesso) ${ }^{1}$ & Clone $^{2}$ & Valor de $\mathrm{E}^{3}$ & $\begin{array}{l}\text { Expressão } \\
\text { diferencial do } \\
\text { gene }^{4}\end{array}$ \\
\hline $\begin{array}{l}\text { Proteína de choque térmico DnaJ } \\
\text { [Arabidopsis thaliana] NP850653 }\end{array}$ & HT-HSS4-D08 & $6 e-47$ & + \\
\hline $\begin{array}{l}\text { Proteína de choque térmico DnaJ } \\
\text { [Arabidopsis thaliana] NP564134 }\end{array}$ & HT-HSS3-D07 & $5 e-68$ & + \\
\hline $\begin{array}{l}\text { Proteína de choque térmico DnaJ } \\
\text { [Atriplex nummularia] P43644 }\end{array}$ & HT-HSS2-C05 & $9 e-41$ & + \\
\hline $\begin{array}{l}\text { Proteína de choque térmico Hsp70 } \\
\text { (chaperona) [Cucurbita maxima] } \\
\text { AAN86275 }\end{array}$ & $\begin{array}{l}\text { HT-HSS2-A06, } \\
\text {-D08 e -E11 }\end{array}$ & $6 e-67$ & + \\
\hline $\begin{array}{l}\text { Proteína de choque térmico Hsp70 } \\
\text { [Oryza sativa] BAB67894 }\end{array}$ & HT-HSS3-D11 & $4 e-71$ & + \\
\hline $\begin{array}{l}\text { Proteína de choque térmico Hsp } 70 \\
\text { [Petunia hybrida] P09189 }\end{array}$ & HT-HSS3-F01 & $6 e-90$ & + \\
\hline $\begin{array}{l}\text { Proteína de choque térmico Hsp70b, } \\
\text { chaperona tipo DnaK [Pisum sativum] } \\
\text { S53499 }\end{array}$ & HT-HSS4-F01 & $8 \mathrm{e}-40$ & + \\
\hline $\begin{array}{l}\text { Proteína de choque térmico Hsp90-1 } \\
\text { (chaperona) [Nicotiana benthamiana] } \\
\text { AAR12193 }\end{array}$ & HT-HSS2-E10 & $4 \mathrm{e}-12$ & + \\
\hline $\begin{array}{l}\text { Proteína de ligação ao RNA } \\
\text { [Arabidopsis thaliana] NP683559 }\end{array}$ & HT-HSS4-A08 & $2 e-53$ & + \\
\hline $\begin{array}{l}\text { Proteína de ligação ao RNA } \\
\text { [Arabidopsis thaliana] NP566957 }\end{array}$ & HT-HSS4-D06 & $8 e-23$ & + \\
\hline $\begin{array}{l}\text { Proteína de ligação da clorofila a/b } \\
\text { [Vigna radiata] AAD27882 }\end{array}$ & HT-HSS4-F11 & $1 \mathrm{e}-22$ & + \\
\hline $\begin{array}{l}\text { Proteína GCPE (biossíntese de } \\
\text { isoprenóides) [Catharanthus roseus] } \\
\text { AAO24774 }\end{array}$ & HT-HSS2-D05 & 2e-41 & + \\
\hline $\begin{array}{l}\text { Proteína Gigantea [Arabidopsis } \\
\text { thaliana] NP564180 }\end{array}$ & HT-HSS4-C05 & $5 e-83$ & + \\
\hline $\begin{array}{l}\text { Proteína GRO11 (expressa em tecidos } \\
\text { em crescimento) [Euphorbia esula] } \\
\text { AAL14628 }\end{array}$ & HT-HSS4-H05 & $9 e-28$ & + \\
\hline
\end{tabular}




\begin{tabular}{|c|c|c|c|}
\hline Função (nº de acesso) ${ }^{1}$ & Clone $^{2}$ & Valor de $\mathrm{E}^{3}$ & $\begin{array}{l}\text { Expressão } \\
\text { diferencial do }_{\text {gene }^{4}}\end{array}$ \\
\hline $\begin{array}{l}\text { Proteína induzida pela luz [Arachis } \\
\text { hypogaea] AAO33591 }\end{array}$ & HT-HSS3-F08 & $2 e-51$ & - \\
\hline $\begin{array}{l}\text { Proteína induzida por desidratação } \\
\text { RD22 [Bruguiera gymnorrhiza] } \\
\text { BAB60847 }\end{array}$ & $\begin{array}{l}\text { HT-HSS4-B08 e } \\
\text {-C08 }\end{array}$ & $7 e-17$ & - \\
\hline $\begin{array}{l}\text { Proteína induzida por desidratação } \\
\text { RD22 [Gossypium hirsutum] } \\
\text { AAL67991 }\end{array}$ & HT-HSS3-F07 & $5 e-17$ & - \\
\hline $\begin{array}{l}\text { Proteína induzida por desidratação } \\
\text { ERD15 [Lycopersicon esculentum] } \\
\text { AAF75749 }\end{array}$ & HT-HSS1-B02 & $2 e-30$ & + \\
\hline $\begin{array}{l}\text { Proteína NAM (“sem meristema } \\
\text { apical”) [Arabidopsis thaliana] D84547 }\end{array}$ & HT-HSS3-B04 & $7 e-04$ & + \\
\hline $\begin{array}{l}\text { Proteína NAM [Nicotiana tabacum] } \\
\text { T52342 }\end{array}$ & HT-HSS3-D12 & $1 e-37$ & + \\
\hline $\begin{array}{l}\text { Proteína NAM [Petunia hybrida] } \\
\text { AAM47025 }\end{array}$ & HT-HSS3-G04 & $5 e-28$ & + \\
\hline $\begin{array}{l}\text { Proteína regulada pela luz [Citrus } \\
\text { paradisi] S52663 }\end{array}$ & HT-HSS2-E08 & $5 e-05$ & + \\
\hline $\begin{array}{l}\text { Proteína regulada pela luz [Solanum } \\
\text { tuberosum] AAQ19850 }\end{array}$ & HT-HSS2-B08 & $2 e-11$ & + \\
\hline $\begin{array}{l}\text { Proteína regulada por auxina } \\
\text { [Arabidopsis thaliana] NP850290 }\end{array}$ & HT-HSS4-D10 & $2 e-52$ & + \\
\hline $\begin{array}{l}\text { Proteína ribosomal 50S L28 [Nicotiana } \\
\text { tabacum] P30956 }\end{array}$ & HT-HSS2-B10 & $3 e-24$ & + \\
\hline $\begin{array}{l}\text { Proteína rica em prolina [Arabidopsis } \\
\text { thaliana] NP567209 }\end{array}$ & HT-HSS3-A06 & $3 e-15$ & + \\
\hline $\begin{array}{l}\text { Proteína tipo CGI-144 (induzida por } \\
\text { patógeno) [Lycopersicon esculentum] } \\
\text { CAC81814 }\end{array}$ & HT-HSS3-C04 & $2 e-27$ & + \\
\hline $\begin{array}{l}\text { Proteína zinc finger [Arabidopsis } \\
\text { thaliana] NP195136 }\end{array}$ & HT-HSS3-A02 & 3e-47 & + \\
\hline
\end{tabular}




\begin{tabular}{|c|c|c|c|}
\hline Função (nº de acesso) ${ }^{1}$ & Clone $^{2}$ & Valor de $\mathrm{E}^{3}$ & $\begin{array}{l}\text { Expressão } \\
\text { diferencial do } \\
\text { gene }^{4}\end{array}$ \\
\hline $\begin{array}{l}\text { Protoclorofilideo redutase [Arabidopsis } \\
\text { thaliana] NP171860 }\end{array}$ & HT-HSS4-F05 & $1 e-29$ & + \\
\hline $\begin{array}{l}\text { Protoporfirina IX magnesio quelatase } \\
\text { [Antirrhinum majus] S37310 }\end{array}$ & HT-HSS4-E06 & $5 e-54$ & + \\
\hline $\begin{array}{l}\text { Regulador de transcrição [Arabidopsis } \\
\text { thaliana] NP564640 }\end{array}$ & HT-HSS3-G05 & $7 e-13$ & + \\
\hline $\begin{array}{l}\text { Ribulose-1,5-bisfosfato carboxilase } \\
\text { (Rubisco activase) [Gossypium } \\
\text { hirsutum] AAG61121 }\end{array}$ & HT-HSS1-H03 & $2 \mathrm{e}-26$ & + \\
\hline $\begin{array}{l}\text { Rubisco activase [Malus domestica] } \\
\text { Q40281 }\end{array}$ & HT-HSS2-C09 & 2e-32 & + \\
\hline $\begin{array}{l}\text { Rubisco activase [Zantedeschia } \\
\text { aethiopica] AAK25800 }\end{array}$ & HT-HSS4-G03 & 7e-22 & + \\
\hline $\begin{array}{l}\text { Serina acetiltransferase } 1 \text { [Nicotiana } \\
\text { tabacum] CAC88762 }\end{array}$ & HT-HSS3-C05 & $9 e-30$ & + \\
\hline $\begin{array}{l}\text { Tioredoxina [Madagascar periwinkle] } \\
\text { T10065 }\end{array}$ & HT-HSS1-B10 & 3e-37 & + \\
\hline $\begin{array}{l}\text { Tioredoxina (induzida sob estresse } \\
\text { oxidativo) [Pisum sativum] CAC69854 }\end{array}$ & HT-HSS2-G07 & 4e-04 & + \\
\hline $\begin{array}{l}\text { Transportador de açúcar [Arabidopsis } \\
\text { thaliana] NP849618 }\end{array}$ & HT-HSS1-E07 & $9 e-32$ & + \\
\hline $\begin{array}{l}\text { Transportador de açúcar [Arabidopsis } \\
\text { thaliana] NP566120 }\end{array}$ & HT-HSS3-C09 & 1e-35 & + \\
\hline $\begin{array}{l}\text { Transportador de açúcar [Arabidopsis } \\
\text { thaliana] NP850964 }\end{array}$ & HT-HSS4-A02 & 2e-39 & + \\
\hline $\begin{array}{l}\text { Transportador de açúcar [Arabidopsis } \\
\text { thaliana] NP187191 }\end{array}$ & HT-HSS4-F07 & $2 e-53$ & + \\
\hline $\begin{array}{l}\text { Transportador de açúcar [Lycopersicon } \\
\text { esculentum] CAC00697 }\end{array}$ & HT-HSS1-C10 & $6 e-26$ & + \\
\hline Transportador de hexose HEX6 & HT-HSS1-B01 & $5 e-15$ & + \\
\hline [Ricinus communis] Q07423 & & & \\
\hline
\end{tabular}




\begin{tabular}{lccc}
\hline \multicolumn{1}{c}{ Função (n ${ }^{\circ}$ de acesso) ${ }^{1}$} & Clone ${ }^{2}$ & Valor de E $^{3}$ & $\begin{array}{c}\text { Expressão } \\
\text { diferencial do } \\
\text { gene }^{4}\end{array}$ \\
\hline $\begin{array}{l}\text { Transportador de nitrato NRT1-5 } \\
\text { [Glycine max] BAB19760 }\end{array}$ & HT-HSS1-D06 & $1 \mathrm{e}-56$ & + \\
$\begin{array}{l}\text { Transportador de zinco ZIP1 [Glycine } \\
\text { max] AAK37761 }\end{array}$ & HT-HSS1-C05 & 9e-43 & + \\
$\begin{array}{l}\text { Treonil-tRNA sintetase [Arabidopsis } \\
\text { thaliana] NP671778 }\end{array}$ & HT-HSS4-A05 & 3e-53 & + \\
$\begin{array}{l}\text { Xiloglucana fucosiltransferase } \\
\text { [Arabidopsis thaliana] NP178420 }\end{array}$ & HT-HSS1-G02 & 5e-41 & + \\
\hline
\end{tabular}

${ }^{1}$ A função de cada gene foi detectada por comparação com seqüências homólogas presentes no NCBI, utilizando-se o programa BlastX. A função associada à seqüência de maior homologia detectada para cada clone de cDNA de cafeeiro, foi relacionada juntamente com a respectiva origem (espécie do organismo e número de acesso do GenBank). ${ }^{2}$ Genes isolados por hibridização subtrativa por supressão, a partir de mRNAs de cafeeiro Híbrido de Timor inoculado com $H$. vastatrix. ${ }^{3} \mathrm{O}$ valor de E foi utilizado para indicar a significância da similaridade de seqüência encontrada para cada gene. ${ }^{4}$ A confirmação da expressão de cada gene isolado de planta inoculada foi determinada utilizando-se a técnica da seleção diferencial. +: gene induzido; -: gene não induzido. 


\subsubsection{Determinação por seleção diferencial da expressão de genes ativados em cafeeiro Híbrido de Timor após inoculação $\operatorname{com} H$. vastatrix}

Foi verificado que de um total de 384 clones de cDNA, presentes na biblioteca subtraída enriquecida de fragmentos de genes de cafeeiro Híbrido de Timor inoculado com H. vastatrix, 297 clones representam genes expressos diferencialmente. A expressão diferencial dos genes pôde ser confirmada através de seleção diferencial, permitindo identificar os clones de cDNA presentes na biblioteca subtraída, que são expressos especificamente na planta durante a resposta de resistência, ativada após a inoculacão com o patógeno. Os resultados obtidos podem ser visualizados na Figura 11. Os clones que hibridizaram com a sonda controle (cDNA C-SR) de forma similar à sonda inoculada (cDNA I-SF) (diferença na intensidade de sinal menor que três vezes), representam os cDNAs presentes, também, na planta não inoculada, que não foram removidos na HSS, não sendo, portanto, diferencialmente expressos (Figuras 11a, b, c e d, membranas A).

Similarmente ao cv. Mundo Novo, os clones codificadores de metalotioneína e algumas proteínas do fotosistema não são diferencialmente expressos, pois são encontrados, também, em plantas não inoculadas (Figura 11 e Tabela 19). Na Figura 11a, por exemplo, os clones HT-HSS1-E11 e F07, não são diferencialmente expressos e codificam proteínas do fotosistema II e I, respectivamente. Da mesma forma, nas Figuras 11b, c e d, podem ser observados os clones HT-HSS2-E04, HT-HSS3-G12, HTHSS4-B10, E08 e F06 que também, hibridizaram com a sonda controle e correspondem a genes codificadores da proteína metalotioneína. Outros clones de cDNA da biblioteca subtraída de Híbrido de Timor não foram especificamente induzidos nas condições estudadas, como aqueles codificadores de alguns compostos envolvidos em vias do metabolismo primário ou de proteínas de estresse induzidas por desidratação (Figura 11 e Tabela 19). Na Figura 11a e b, por exemplo, pode ser observado que os clones HTHSS1-F06 e HT-HSS2-B02, codificadores, respectivamente, de malato desidrogenase e de glicolato oxidase, hibridizaram com a sonda de cDNA proveniente de plantas não 
inoculadas, como também, os clones HT-HSS3-F07, HT-HSS4-B08 e C08 codificadores de proteínas induzidas por desidratação (Figura 11c e d).

Além destes, alguns clones de genes apresentando funções relacionadas à defesa de plantas contra fitopatógenos não foram ativados especificamente nas plantas inoculadas. Ao contrário do observado para o cv. Mundo Novo, os clones, HT-HSS1A01 e HT-HSS3-A10, codificadores de catalase não foram diferencialmente expressos em Híbrido de Timor (Figura 11a, Figura 11c e Tabela 12). O clone HT-HSS1-G01 codificador de uma proteína com repetições de anquirina, envolvida na percepção e transdução de sinal e o clone HT-HSS4-E11, codificador de ubiquitina, envolvida na degradação controlada de proteínas, hibridizaram com a sonda controle proveniente de plantas não inoculadas (Figura 11a e 11d, Tabelas 16 e 18). 


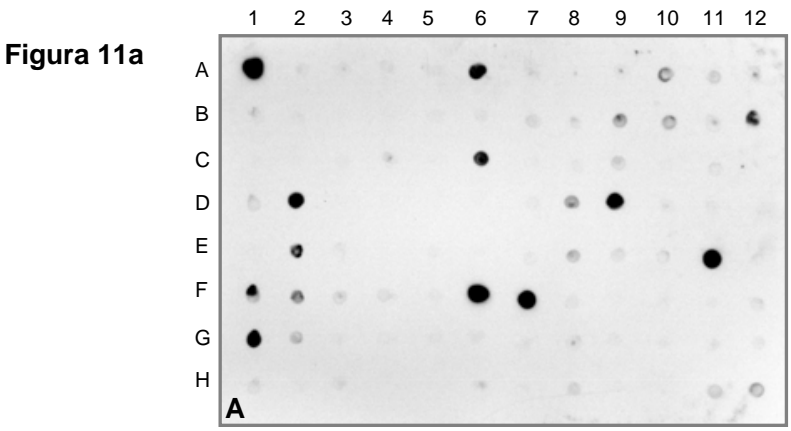

Figura 11b

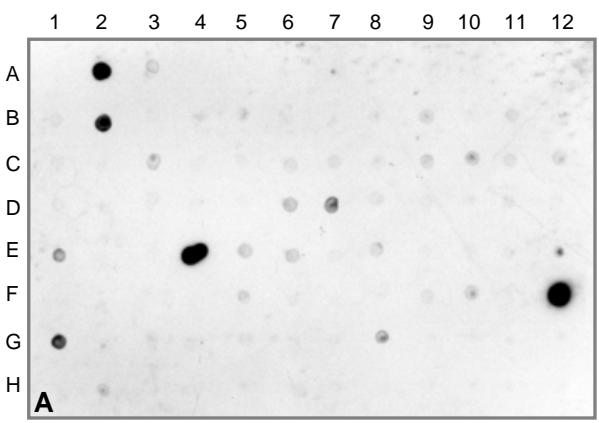

Figura 11c

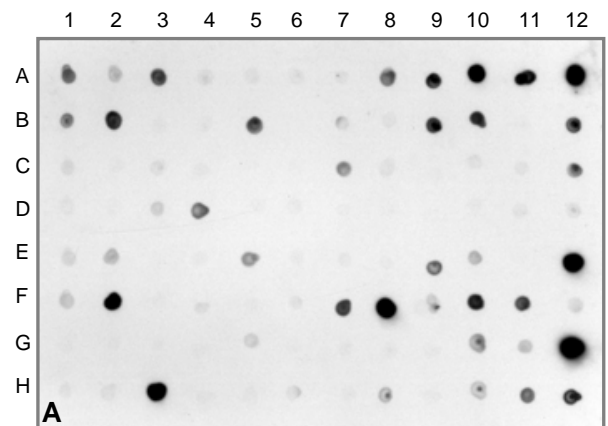

Figura 11d

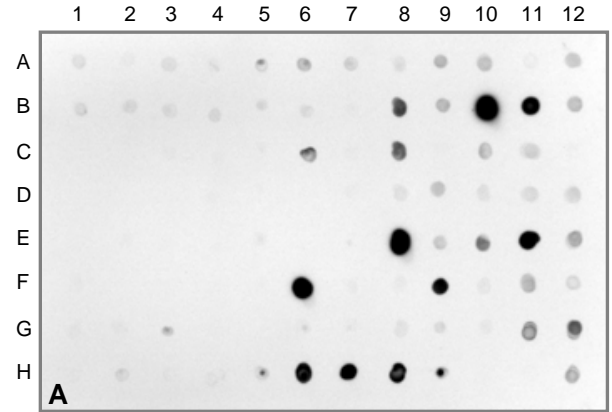

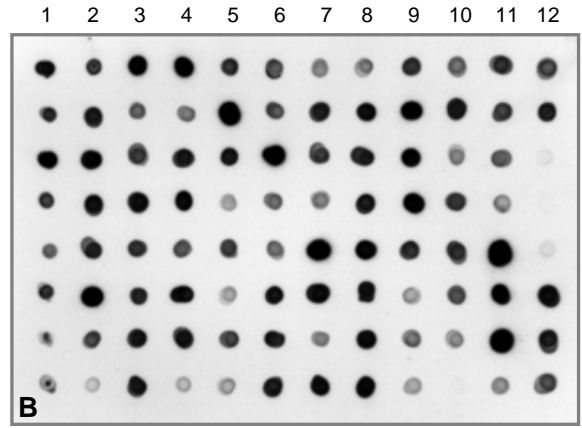
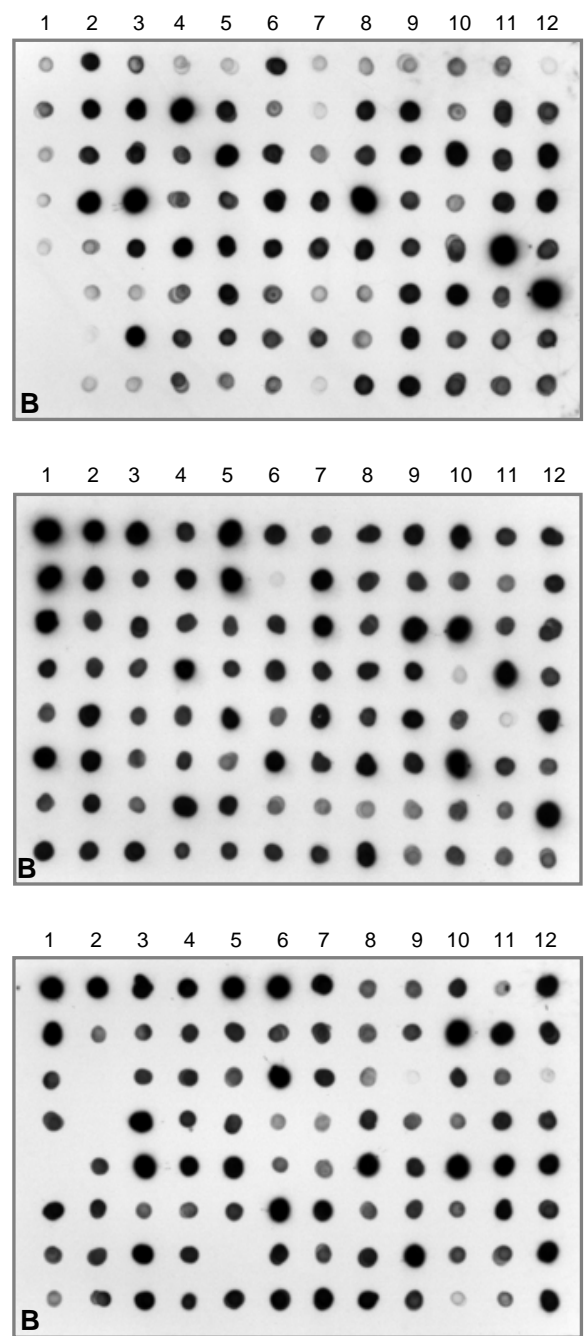

Figura 11 - Seleção diferencial dos clones de cDNA da biblioteca subtraída de cafeeiro Híbrido de Timor inoculado com $H$. vastatrix.

A: membranas hibridizadas com sonda de cDNA, proveniente de plantas controle; B: membranas hibridizadas com sonda de cDNA, proveniente de plantas inoculadas. Sondas marcadas com digoxigenina; hibridização feita a $65^{\circ} \mathrm{C}$ por $16 \mathrm{~h}$. Figura 11a: $1^{\circ}$ grupo de clones de Híbrido de Timor, HT-HSS1; Figura 11b: $2^{\circ}$ grupo de clones, HT-HSS2; Figura 11c: $3^{\circ}$ grupo de clones, HT-HSS3; Figura 11d: $4^{\circ}$ grupo de clones, HT-HSS4. 


\subsection{Comparação de genes isolados por hibridização subtrativa por supressão induzidos em cafeeiro cv. Mundo Novo após tratamento com indutor de resistência, com aqueles ativados em Híbrido de Timor em resposta à $H$. vastatrix}

Foi verificado que de um total de 302 clones de cDNAs de genes isolados por HSS e especificamente ativados em cafeeiro cv. Mundo Novo pelo indutor de resistência ASM, 132 clones codificam proteínas que não apresentaram similaridade com seqüências presentes no GenBank, 30 clones foram similares à proteínas hipotéticas de função desconhecida, 49 clones representam genes implicados em mecanismos de resistência e 91 clones estão associados à manutenção celular e desenvolvimento vegetal (Figura 12). Por outro lado, foi constatado que de um total de 297 clones de cDNAs de genes ativados em cafeeiro Híbrido de Timor após inoculação com H. vastatrix, 105 clones não apresentaram similaridade com seqüências do GenBank, 37 clones são análogos à proteínas hipotéticas presentes no banco de dados, 65 clones correspondem a genes envolvidos em mecanismos de defesa e 90 clones estão associados à manutenção celular e desenvolvimento vegetal (Figura 13). Como pode ser observado nas Figuras 12 e 13, o Híbrido de Timor apresentou um número maior de genes implicados em mecanismos de defesa de plantas contra fitopatógenos, ativados após a inoculação com H. vastatrix, do que o cv. Mundo Novo tratado com ASM. Entretanto, foi encontrado no cv. Mundo Novo um número maior de genes induzidos pelo ASM que não apresentaram similaridade com seqüências do GenBank, do que no Híbrido de Timor inoculado com H. vastatrix.

Nas Figuras 14 e 15, estão representados os números totais de genes ativados, respectivamente, em cafeeiro cv. Mundo Novo pelo ASM e no Híbrido de Timor através da inoculação com $H$. vastatrix, implicados em cada um dos diferentes processos associados à resistência de plantas contra fitopatógenos, detectados nas condições estudadas. Os clones de cDNA de genes ativados, envolvidos na síntese de compostos de baixo peso molecular com função sinalizadora de respostas de defesa (Tabelas 7 e 15) 
foram incluídos no grupo relacionado à percepção e transdução de sinal (Tabelas 8 e16). Pode ser observado, que na interação Híbrido de Timor- $H$. vastatrix, foi detectado um número maior de genes associados à percepção e transdução de sinal e à síntese e transporte de compostos do metabolismo secundário, do que no cv. Mundo Novo com resistência induzida pela aplicação do ASM. Entretanto, o número de genes codificadores de proteínas antimicrobianas e de compostos associados ao estresse oxidativo e morte celular foi maior no cv. suscetível com resistência induzida pelo ASM, do que no cafeeiro resistente Híbrido de Timor inoculado com o patógeno (Figuras 14 e 15). 


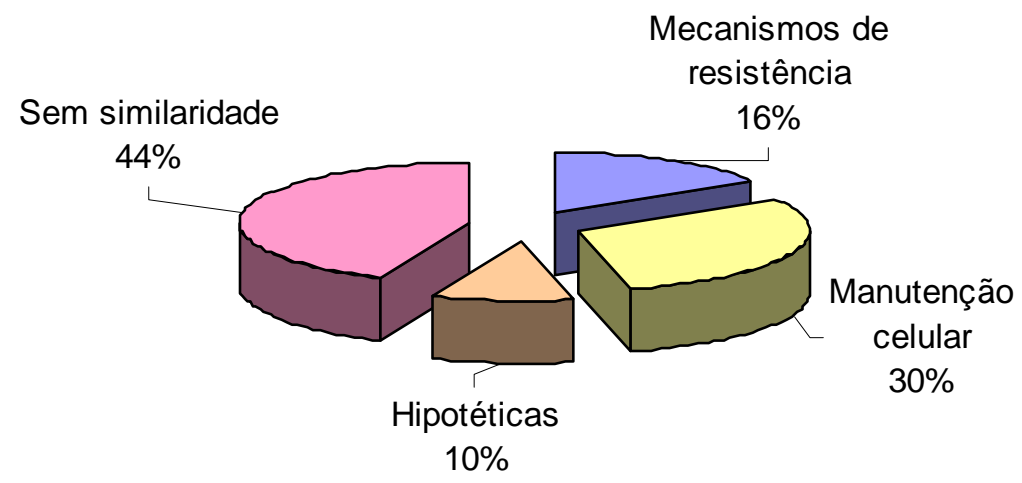

Figura 12 - Genes ativados em cafeeiro cv. Mundo Novo tratado com acibenzolar-S-metil (ASM).

Genes isolados por hibridização subtrativa por supressão (HSS), a partir de mRNAs de cafeeiro, 72 h após o tratamento com ASM (200 $\mu$ g de i.a./mL).

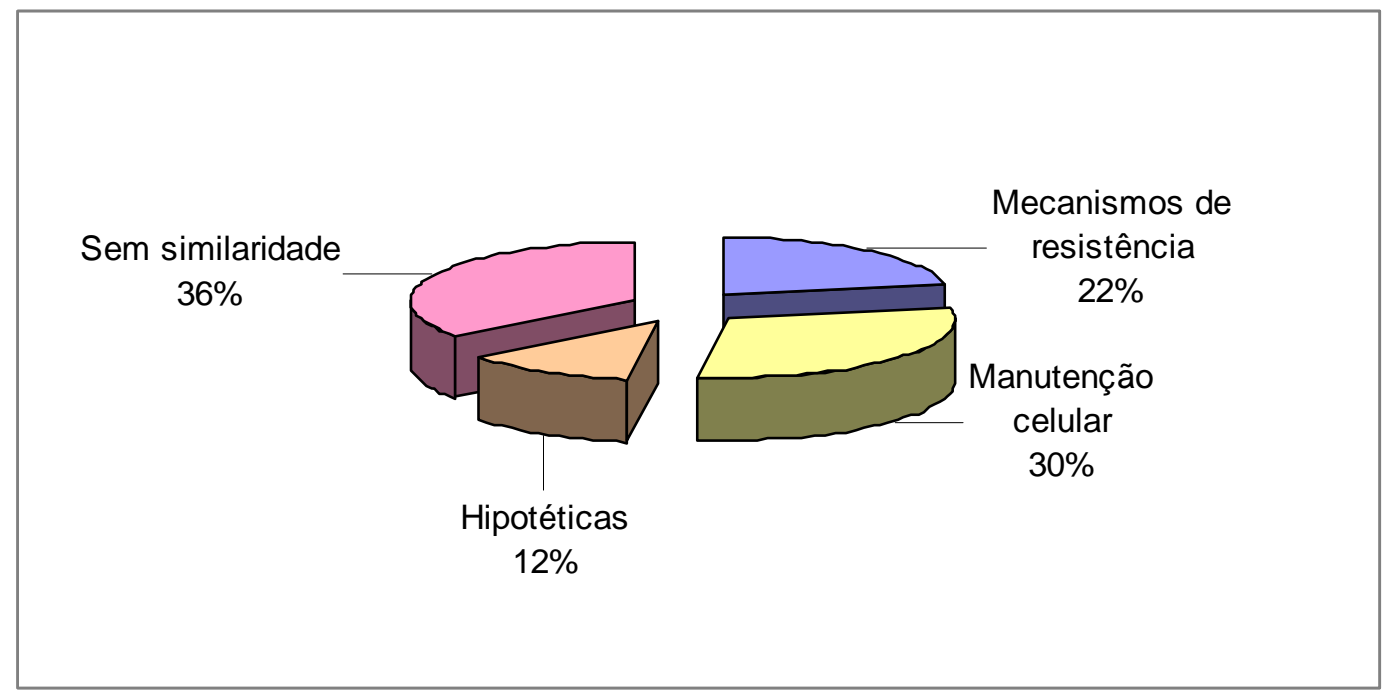

Figura 13 - Genes ativados em cafeeiro Híbrido de Timor inoculado com H. vastatrix.

Genes isolados por HSS, a partir de mRNAs de cafeeiro, 72 h após a inoculação com o patógeno $(2 \mathrm{mg} / \mathrm{mL})$.

Sem similaridade: porcentagem (\%) de clones de cDNA de genes codificadores de proteínas sem similaridade com seqüências presentes no GenBank. Hipotéticas: \% de clones similares à proteínas hipotéticas de função desconhecida. Mecanismos de resistência: \% de clones associados aos mecanismos de defesa de plantas contra fitopatógenos. Manutenção celular: \% de clones associados à manutenção celular e desenvolvimento vegetal. 


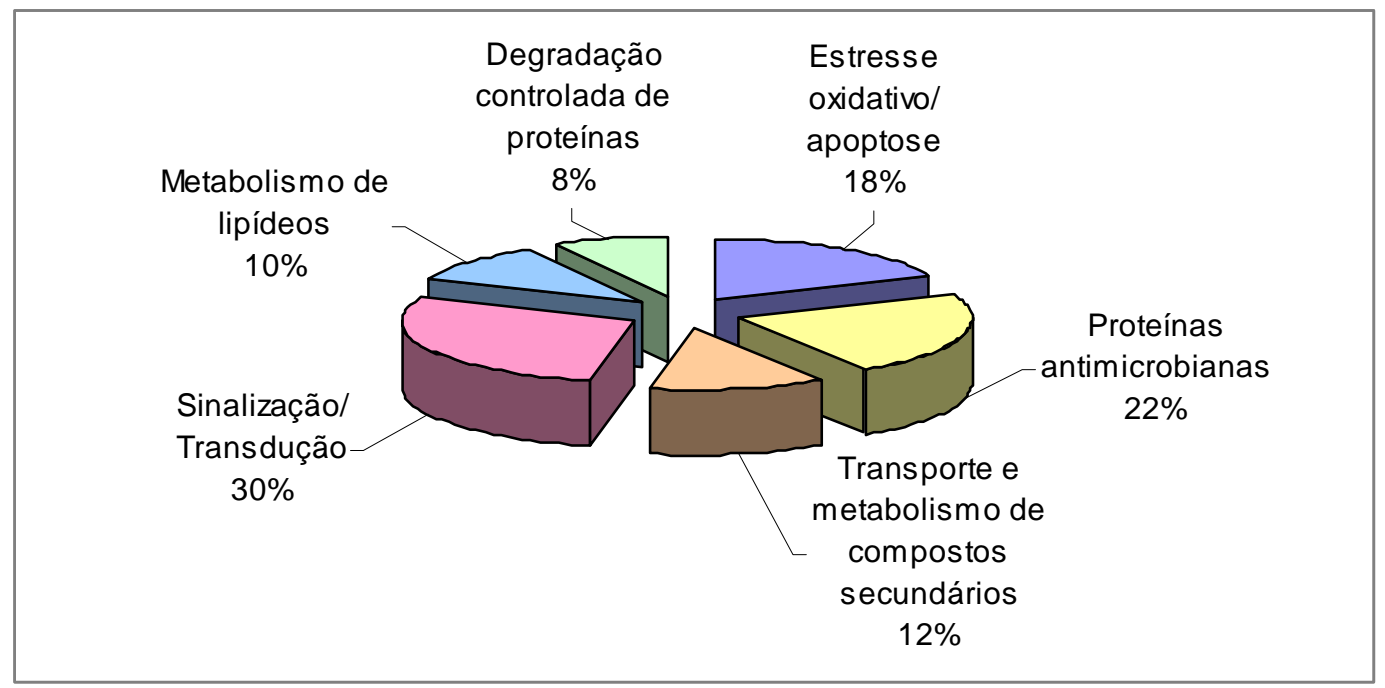

Figura 14 - Genes associados à resistência sistêmica adquirida, ativados em cafeeiro cv. Mundo Novo através da aplicação de acibenzolar-S-metil (ASM).

Genes isolados por hibridização subtrativa por supressão (HSS), a partir de mRNAs de cafeeiro, 72 h após o tratamento com ASM (200 $\mu$ g de i.a./mL).

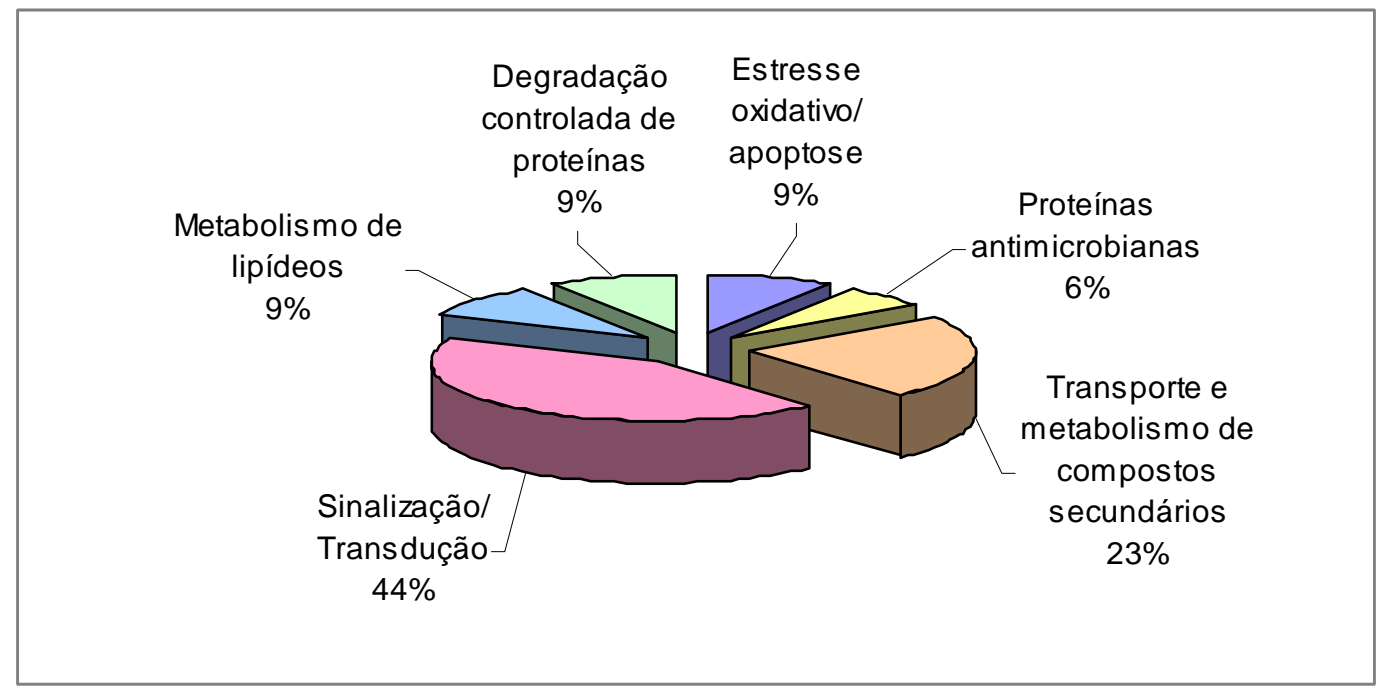

Figura 15 - Genes associados à resistência vertical ativados em cafeeiro Híbrido de Timor após a inoculação com H.vastatrix.

Genes isolados por HSS, a partir de mRNAs de cafeeiro, 72 h após a inoculação com o patógeno (2 mg/mL). Porcentagem de clones de cDNA de genes codificadores de proteínas antimicrobianas, de proteínas envolvidas no estresse oxidativo e na morte celular; na síntese e transporte de compostos do metabolismo secundário; na percepção e transdução de sinal que leva à ativação do estado de resistência, no metabolismo de lipídeos e na degradação controlada de proteínas. 
4.5. Isolamento de cDNAs dos genes codificadores de $\beta$-1,3-glucanases de cafeeiro cv. Mundo Novo e de Híbrido de Timor através da técnica RACE

\subsubsection{Obtenção dos clones de cDNA dos genes codificadores das $\beta$-1,3-glucanases de cafeeiro cv. Mundo Novo e de Híbrido de Timor e digestão com EcoRI}

Através da técnica RACE, foi possível isolar os clones de cDNAs dos genes codificadores de $\beta$-1,3-glucanases a partir de RNAs totais obtidos de cafeeiro cv. Mundo Novo e Híbrido de Timor, 72 H após o tratamento com ASM e inoculação com $H$. vastatrix, respectivamente. Os cDNAs, apresentando as extremidades 3' e 5' dos genes, puderam ser sintetizados utilizando-se os primers específicos desenhados com base nas seqüências parciais determinadas para os clones MN-HSS2-B03 e HT-HSS1G05 presentes nas bibliotecas subtraídas, obtidas para cafeeiro Mundo Novo e Híbrido de Timor, respectivamente. A Figura 16 mostra a eletroforese em gel de agarose dos clones de cDNA contendo as extremidades 5' e 3' dos genes, após digestão com EcoRI. Podem ser visualizadas as bandas dos vetores usados para a clonagem dos genes e as bandas dos insertos referentes aos cDNAs clonados obtidos pela técnica RACE. Pode ser observada a presença de uma única banda de cDNA para cada clone isolado, com exceção da glucanase-HT3' que apresenta duas bandas, pois este inserto possui sítio de restrição para EcoRI. Esses resultados confirmaram a presença dos insertos nos vários clones obtidos e possibilitaram realizar uma estimativa dos respectivos tamanhos, antes de ser efetuado o seqüenciamento dos plasmídeos.

\subsubsection{Determinação das seqüências completas dos cDNAs dos genes codificadores de $\beta$-1,3-glucanases de cafeeiro cv. Mundo Novo e de Híbrido de Timor}

Através dos procedimentos utilizados foi possível obter as seqüências completas dos genes codificadores de $\beta$-1,3-glucanases de cafeeiro cv. Mundo Novo e de Híbrido de Timor, ativados após tratamento com o indutor de resistência ASM e inoculação com $H$. vastatrix, respectivamente. Um esquema do procedimento utilizado 
para obter as seqüências completas dos genes pode ser visualizado na Figura 17. Os seqüenciamentos realizados nos sentidos senso e anti-senso, dos produtos de amplificação das extremidades 5' e 3' dos genes obtidos através da técnica RACE e dos clones MN-HSS2-B03 e HT-HSS1-G05 das bibliotecas subtraídas, permitiram obter as seqüências completas dos genes de cafeeiro Híbrido de Timor e Mundo Novo. Como o clone de cDNA contendo a extremidade 5' do gene de cafeeiro Mundo Novo apresentou um tamanho entre 1.018 e 1.636 pb (Figura 16) foi necessário realizar uma digestão com a enzima HindIII para promover uma diminuição do tamanho do inserto. Esse procedimento permitiu o seqüenciamento da região central do clone de cDNA contendo a extremidade 5' do gene de Mundo Novo.

As seqüências completas dos cDNAs e dos aminoácidos (aa) das proteínas codificadas pelos genes de Mundo Novo (1.937 nucleotídeos + cauda poli A; 2.004 bases; códon iniciador no nucleotídeo 392; códon finalizador no nucleotídeo 1.834; 480 aa) e Híbrido de Timor (1.235 nucleotídeos + cauda poli A; 1.266 bases; códon iniciador no nucleotídeo 45; códon finalizador no nucleotídeo 1.076; 343 aa) estão apresentadas nas Figuras 18 e 19, respectivamente.

Através do programa BlastX foi possível verificar que as seqüências de cDNA de cafeeiro apresentaram similaridade com seqüências de $\beta$-1,3-glucanases depositadas no NCBI, provenientes de várias plantas. Foi realizada uma comparação de seqüências de aminoácidos das proteínas $\beta$-1,3-glucanases de cafeeiro cv. Mundo Novo e de Híbrido de Timor com aquelas provenientes de outras plantas presentes no GenBank, através de alinhamento pelo programa ClustalX. As proteínas de Mundo Novo e Híbrido de Timor apresentaram alta similaridade de seqüências com as $\beta$-1,3-glucanases (glicosil hidrolases família 17) de $A$. thaliana ( $\mathrm{E}=0, \mathrm{n}^{\circ}$ de acesso NP176656) e de Lycopersicon esculentum ( $\mathrm{E}=\mathrm{e}-116, \mathrm{n}^{\circ}$ de acesso S44365), respectivamente, diferindo bastante entre si (Figuras 20 e 21). A análise atavés do programa CD-Search do NCBI revelou, que as proteínas codificadas pelos genes isolados de cafeeiro, apresentaram, também, os domínios conservados de $\beta$-1,3-glucanase (COG 5309) e de glicosil hidrolase da família 17 (pfam 00332). 
As seqüências de cDNAs obtidas para os genes codificadores de $\beta$-1,3glucanases de cafeeiro Híbrido de Timor e Mundo Novo foram depositadas no GenBank e após avaliação e aprovação pela comissão de análise de seqüências submetidas ao banco de dados (“GenBank Submissions Staff”) receberam a numeração AY389811 e AY389812, respectivamente. As seqüências de aminoácidos deduzidas a partir das seqüências de nucleotídeos dos cDNAs de cafeeiro Híbrido de Timor e Mundo Novo, receberam os números de acesso AAQ90286 e AAQ90287, respectivamente (Anexos A e B).

Através do programa PSORT foi possível fazer uma previsão da localização das proteínas nas células vegetais e análise da presença de peptídeo sinal. As duas proteínas apresentam peptídeo sinal com sítio de clivagem. Entretanto, a proteína de cafeeiro Mundo Novo, está localizada, possivelmente, na membrana celular, enquanto que a de Híbrido de Timor é extracelular. Através do programa de previsão ExPASy foi possível estimar algumas propriedades das $\beta$-1,3-glucanases de cafeeiro. A proteína madura de Híbrido de Timor apresenta ponto isoelétrico (pI) estimado em 9, 05 e peso molecular igual a 34.195,56 Daltons, enquanto que a de Mundo Novo possui pI igual a 4,97 e peso molecular de 50.496,12 Daltons (Tabela 20). A proteína de Híbrido de Timor é básica, enquanto que a de Mundo Novo apresenta caráter ácido. 




Figura 16 - Eletroforese em gel de agarose $(0,8 \%)$ dos clones de cDNA dos genes codificadores das $\beta$-1,3-glucanases de cafeeiro cv. Mundo Novo e de Híbrido de Timor, após digestão com EcoRI.

1- Padrão de DNA de 1Kb ladder; 2- Glucanase-MN3’: clone contendo cDNA apresentando a extremidade 3' do gene codificador da $\beta$-1,3-glucanase de cafeeiro cv. Mundo Novo. Gene clonado no vetor pCR 4-TOPO (Invitrogen); 3- Glucanase-MN5': clone contendo cDNA com a extremidade 5' do gene codificador da $\beta$-1,3-glucanase de cafeeiro cv. Mundo Novo. Gene clonado no vetor pGEM-T Easy (Promega); 4- Glucanase-HT3': clone contendo cDNA com a extremidade 3' do gene codificador de $\beta$-1,3-glucanase de cafeeiro Híbrido de Timor. Gene clonado no vetor pGEM-T Easy; 5- Glucanase-HT5': clone contendo cDNA com a extremidade 5' do gene codificador da $\beta$-1,3-glucanase de cafeeiro Híbrido de Timor. Gene clonado no vetor pGEM-T Easy. Após a digestão dos clones com EcoRI podem ser visualizadas as bandas dos vetores usados para a clonagem dos genes e as bandas referentes aos cDNAs clonados (insertos). Para a glucanase-HT3' podem ser visualizadas duas bandas, pois este inserto apresenta sítio de restrição para EcoRI. Foram aplicados no gel $8 \mu \mathrm{L}$ de cada amostra. 
glucanase-MN5'-HindIII-F glucanase-MN5'-HindIII-R

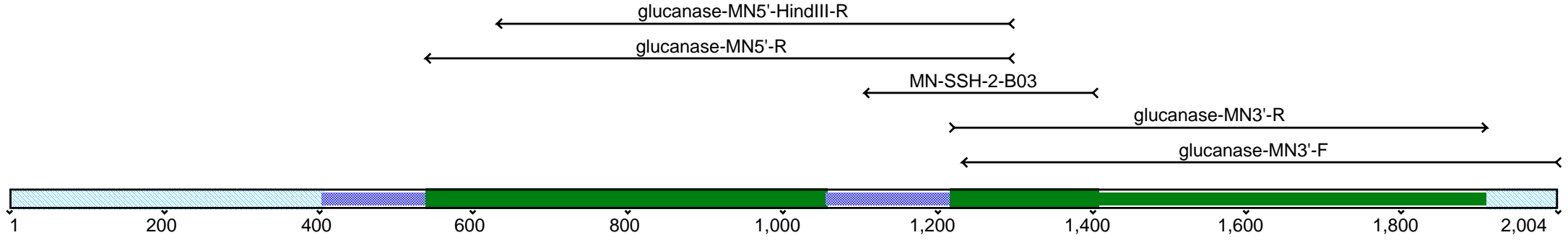

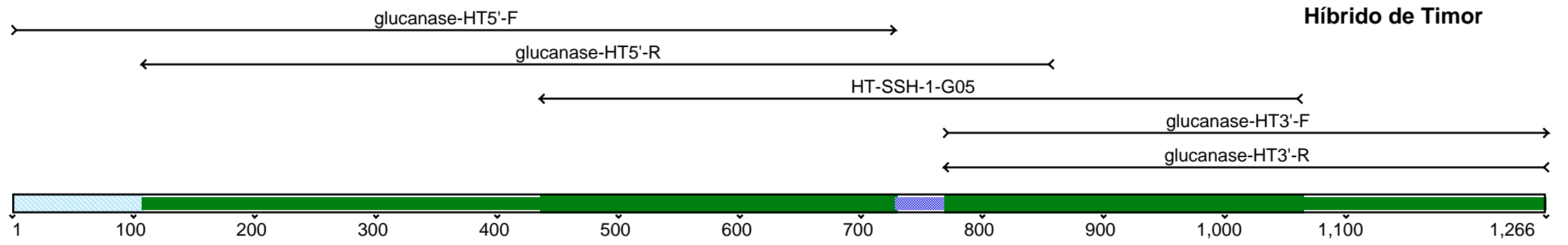

Figura 17 - Representação esquemática do procedimento utilizado para obter as seqüências completas dos genes codificadores das $\beta$-1,3glucanases de cafeeiro cv. Mundo Novo e Híbrido de Timor.

Os clones contendo os cDNAs apresentando as extremidades 3' e 5' dos genes codificadores de $\beta$-1,3-glucanase, obtidos através da técnica RACE, foram seqüenciados em ambos sentidos ( $\mathrm{F}=$ "forward", senso; $\mathrm{R}=$ "reverse", anti-senso). As barras inferiores representam os genes completos (2.004 nucleotídeos para o gene de M. Novo e 1.266 nucleotídeos para o H. Timor) e os segmentos indicam os clones seqüenciados. MN-SSH-2-B03: fragmento de gene de glucanase da biblioteca subtraída obtida para cafeeiro M. Novo tratado com ASM; glucanase-MN5' e glucanase-MN3': clones de cDNA, contendo, respectivamente, as extremidades 5' e 3' de gene de M. Novo; glucanaseMN5'-HindIII: clone de cDNA, contendo a extremidade 5', após digestão com HindIII; HT-SSH-1-G05: fragmento de gene de glucanase da biblioteca subtraída obtida para cafeeiro H. Timor inoculado com H. vastatrix; glucanase-HT5' e glucanase-HT3’: clones de cDNA, contendo, respectivamente, as extremidades 5' e 3' de gene de H. Timor. 
1 ATTCACATTC GTCATAAAAG CTTTTCCGTT TTTCTCGgAT ATAGTTATTA

51 GTATCTTGAT TTATTCACAA AATGATATTT GGGGTTTTCT TATTTCATTG

101 ATTACTTGGA AAAAAGCATT GGATTTTGGC TGATTTTTCG TACCCACCTG

151 CCAAAATCCA TTTCTTTCTT TTCTTTTTCT TATAAATCTG AATCССTCCT

201 CTTTGTTTTT TTCTTTTTCT TTTTGTCCCT СTTCTCTTCT CTTTTTTTTT

251 TTTTTTATTT GACAAAAAGA AGAGGAACCT TTATTTATCT TGAAAAAGTC

301 TTGGTTCACA AGTGATAAAG ATTGTATTTT TACTCATAGG GAATAATAAA

351 TTCCTCTGCA GGGCTGATTT TCAGTTCTTT TTTGGCTGAA GATGTCAAGA

401 ATAAAGCTTT TATTTAGCTT GTTGGTATTG GTATTTGTTG GGATTAGTAA

451 TGATGTGGTG GGTGTTGAAG GGCTTGGTGT GAACTGGGGT ACACAGGCAA

501 CGCACAAGTT GCCTCCTAAG GTGGTAGTGC AAATGCTGAA AGACAATGGA

551 ATAACAAAAG TGAAACTGTT TGATGCAGAC GCATCAACTA TGAGTGCTCT

601 GGCTGGCTCT AATATTGAAG TAATGGTTGC TATTCCTAAT GACCAGCTTC

651 TTGTTATGAA TGACTACGAT AGAGCTAAGA ACTGGGTTAA GCGCAATGTC

701 ACTGTCTACC TTTTCAATGG AGgTGTTAAC ATAAAGTATG TAGCAGTTGG

751 TAATGAGCCA TTTCTTGCAT CTTACAATAA CTCATTCGTG AACACCACAT

801 TCCCAGCCCT TCAGAACATA CAAAACGCCC TAAATGATGC TGGGCATGGT

851 GACACCATAA AGGCAACTGT GCCGTTAAAT GCTGATGTCT ATTTTTCACC

901 AGAAGGCAAT CCTGTTCCCT CTGCTGGAAG ATTTCGGGCA GATATCAGTT

951 CCCAAATGAC CCAGATTGTT CAGTTCTTGA ACCAAAATAA TGCACCTTTT

1001 ACTGTAAATA TTTACCCTTT CTTGAGTCTT TACTTAAACT CACACTTCCC

1051 AGTTGACTAT GCCTTCTTTG ATGGGGCTGC TAACCCCATA GTTGATGATG

1101 GAGTTCAGTA CACAAATGTC TTCGATGCCA ACTTTGATGC CTTGGTTTCA

1151 GCACTAAAGG GATTGGGGTA TGGAAGCATG AATATTTTGG TTGGAGAGGT

1201 TGGATGGCCC ACTGATGGGG ACAGGAATGC CAATGTAAAT TATGCTATTA

1251 GGTTTTACAG GGGTCTTCTC CCAAGACTTG CCGCAAATAA AGGAACCCCA

1301 CTTCGgCCTG GTTATATAGA GGTTTACTTG TTTGGACTTC TAGATGAAGA

1351 TTTGAAGAGT GTAGCTCCTG GTAATTTTGA GCGCCATTGG GGGATTTTCA

1401 GGTACGATGG ACAGCCCAAG TTTCCTATGG ATCTTTCAGG TCAGTTGCAA

1451 GACAAATATC TTGTGGGGGC GCAGAATGTG CAGTATTTTC CTGCTAAATG

1501 GTGCCAGTTC AATCCTAATG CAAAAGACTT GAGCAAACTC GTTGAGAATA

1551 TCAATTATGC TTGCACATTT GCAGATTGCA CAGCTCTTGG GTATGGTTCG

1601 TCTTGTAATG GTTTGGATGC CAATGGGAAT GCATCATATG CATTTAATAT

1651 GTACTTCCAG GTCCAGAACC AAGGAGATTT GAGCTGCAAT TTTCAAGGTT

1701 TAGCTATGGT GACTGAGCAG AACATATCTC AAGCAAATTG CAACTTCACC

1751 ATTCAAATTG CGACCTCTTC TTCTATGAAG TTGTTGCCGG TAGCTGGATT

1801 ATATTTAGCA GCATTAACAT TTCTATTGCT ATAGGCATCT TTCTGTAGAT

1851 ACCTCACATG TATTATTTTT GATACATTCA TTTGAGGCAA TAATTTATAC

1901 TAATACAGCT GGGCCCTTTT TTGCCCTGCA GATTCATTTG ATAAAAAAAA

1951 AAAAAAAAAA AAAAAAAAAA AAAAAAAAAA AAAAAAAAAA AAAAAAAAAA

2001 AAAA

1 MSRIKLLFSL LVLVFVGISN DVVGVEGLGV NWGTQATHKL PPKVVVQMLK 51 DNGITKVKLF DADASTMSAL AGSNIEVMVA IPNDQLLVMN DYDRAKNWVK 101 RNVTVYLFNG GVNIKYVAVG NEPFLASYNN SFVNTTFPAL QNIQNALNDA 151 GHGDTIKATV PLNADVYFSP EGNPVPSAGR FRADISSQMT QIVQFLNQNN 201 APFTVNIYPF LSLYLNSHFP VDYAFFDGAA NPIVDDGVQY TNVFDANFDA 251 LVSALKGLGY GSMNILVGEV GWPTDGDRNA NVNYAIRFYR GLLPRLAANK 301 GTPLRPGYIE VYLFGLLDED LKSVAPGNFE RHWGIFRYDG QPKFPMDLSG 351 QLQDKYLVGA QNVQYFPAKW CQFNPNAKDL SKLVENINYA CTFADCTALG 401 YGSSCNGLDA NGNASYAFNM YFQVQNQGDL SCNFQGLAMV TEQNISQANC 451 NFTIQIATSS SMKLLPVAGL YLAALTFLLL

Figura 18 - cDNA e seqüência de aminoácidos da $\beta$-1,3-glucanase de cafeeiro cv. Mundo Novo.

Os códons iniciador (ATG) e finalizador (TAG) estão sinalizados em negrito. O peptídeo sinal está sublinhado e a seta indica o possível local de clivagem. 


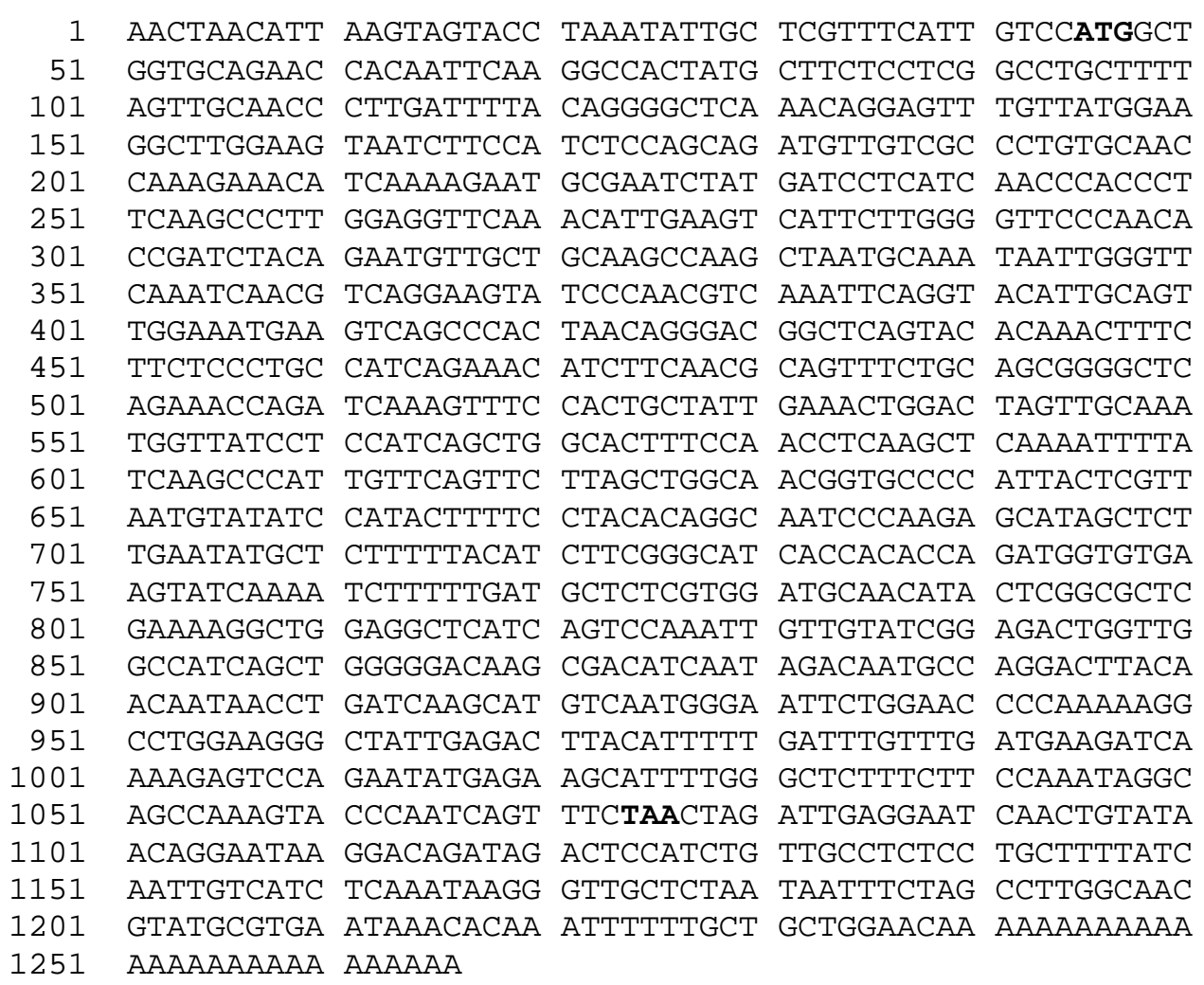

1 MAGAEPQFKA TMLLLGLLLV ATLDFTGAQT GVCYGRLGSN LPSPADVVAL 51 CNQRNIKRMR IYDPHQPTLQ ALGGSNIEVI LGVPNTDLQN VAASQANANN 101 WVQINVRKYP NVKFRYIAVG NEVSPLTGTA QYTNFLLPAI RNIFNAVSAA 151 GLRNQIKVST AIETGLVANG YPPSAGTFQP QAQNFIKPIV QFLAGNGAPL 201 LVNVYPYFSY TGNPKSIALE YALFTSSGIT TPDGVKYQNL FDALVDATYS 251 ALEKAGGSSV QIVVSETGWP SAGGQATSID NARTYNNNLI KHVNGNSGTP 301 KRPGRAIETY IFDLFDEDQK SPEYEKHFGL FLPNRQPKYP ISF

Figura 19 - cDNA e seqüência de aminoácidos da $\beta$-1,3-glucanase de cafeeiro cv. Híbrido de Timor.

Os códons iniciador (ATG) e finalizador (TAA) estão sinalizados em negrito. O peptídeo sinal está sublinhado e a seta indica o possível local de clivagem. 


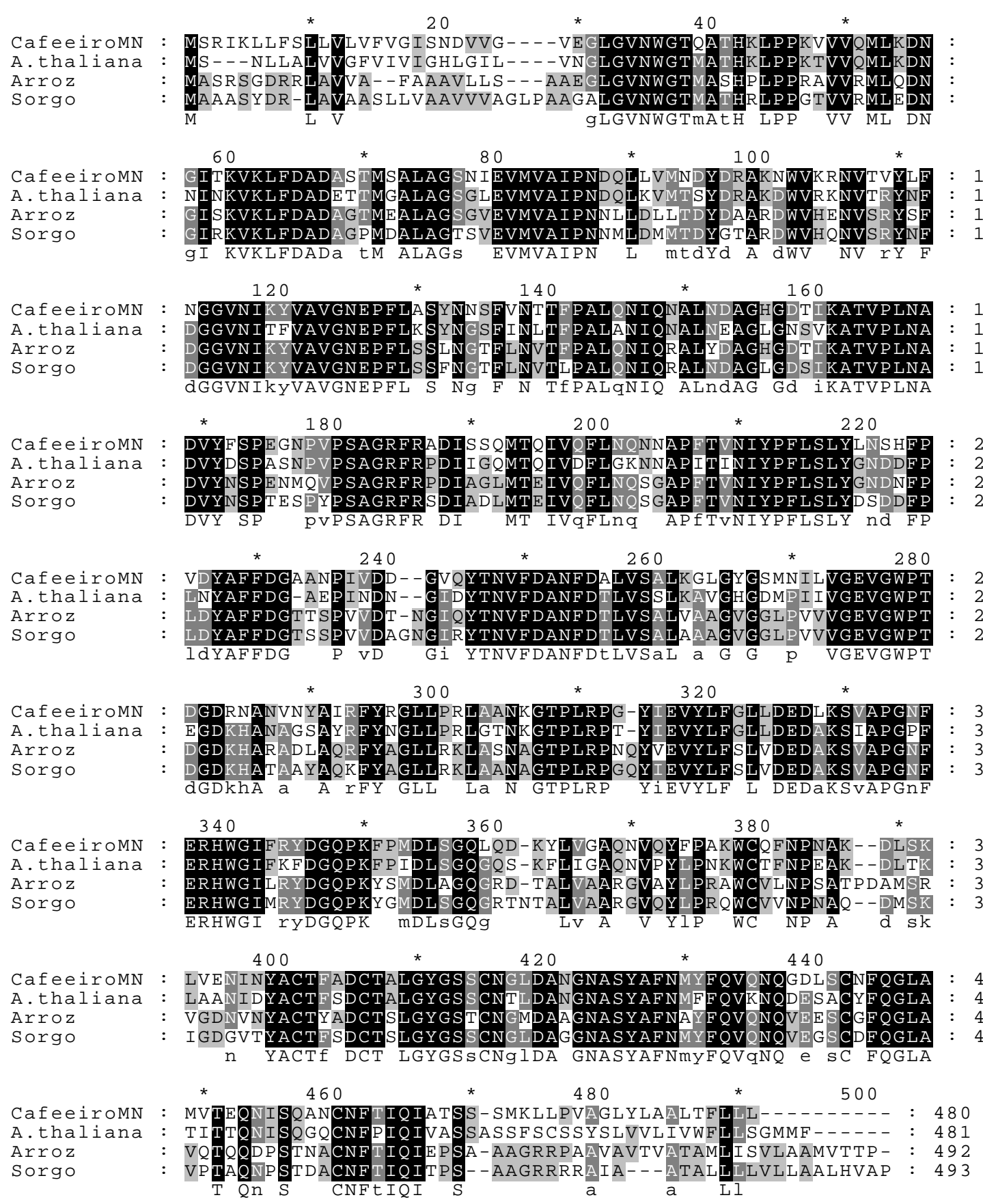

Figura 20 - Alinhamento de seqüências de aminoácidos da proteína $\beta$-1,3-glucanase de cafeeiro cv. Mundo Novo com aquelas de Arabidopsis, arroz e sorgo presentes no GenBank. 


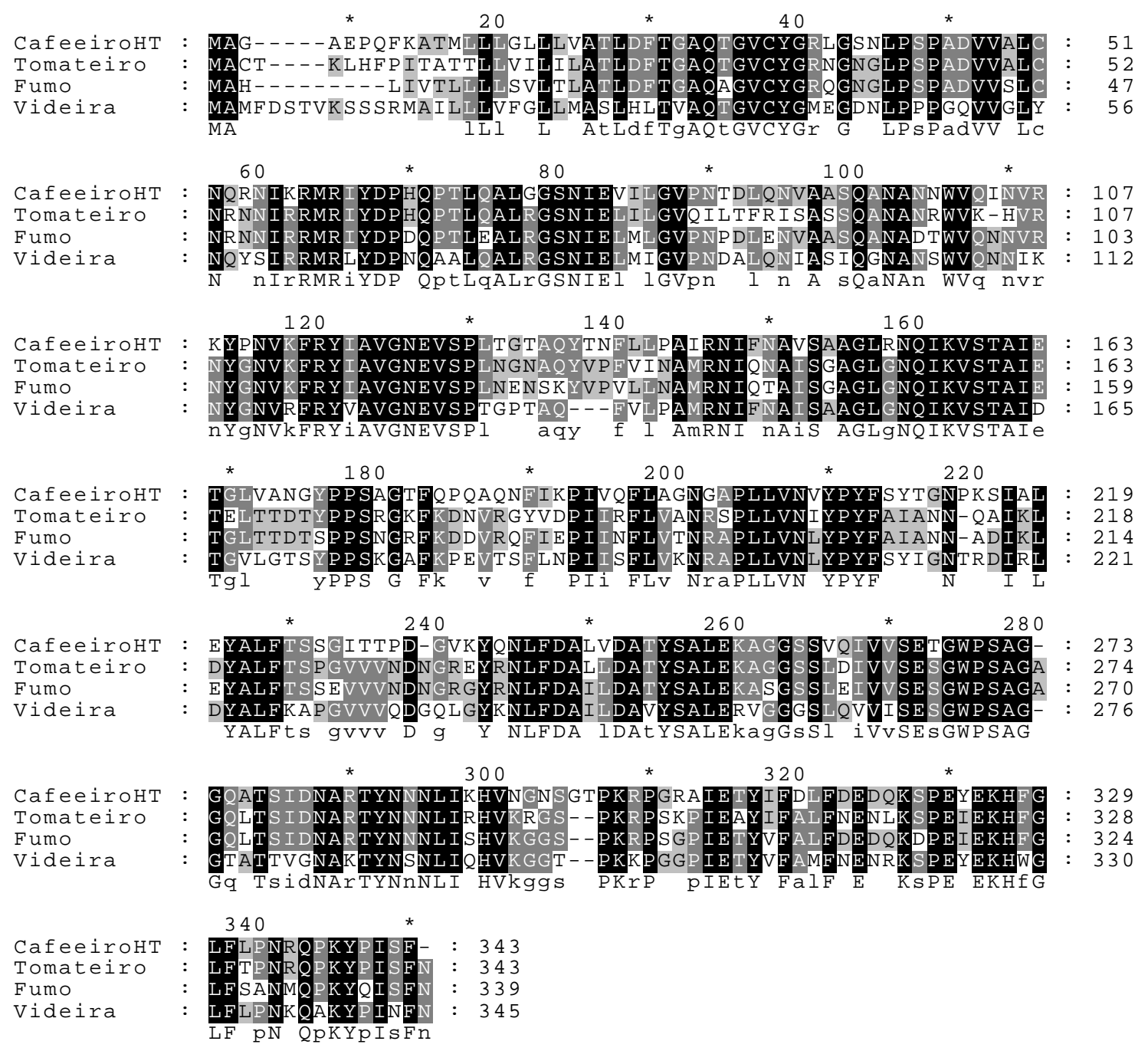

Figura 21 - Alinhamento de seqüências de aminoácidos da proteína $\beta$-1,3-glucanase de cafeeiro cv. Híbrido de Timor com aquelas de tomateiro, fumo e videira presentes no GenBank. 
Tabela 20. Características das proteínas $\beta$-1,3-glucanases codificadas por genes isolados de cafeeiro cv. Mundo Novo e Híbrido de Timor, após tratamento com acibenzolar-S-metil ou inoculação com H. vastatrix, respectivamente.

\begin{tabular}{lll}
\hline PROPRIEDADES $^{1}$ & MUNDO NOVO & HÍBRIDO DE TIMOR \\
\hline Localização na célula vegetal & Membrana celular & Extracelular \\
Ponto isoelétrico & 4,97 & 9,05 \\
Peso molecular (kD) & 50,5 & 34,2 \\
Número de aminoácidos & 480 & 343 \\
Peptídeo sinal & SIM & SIM \\
(com sítio de clivagem) & & \\
Similaridade & A. thaliana & L. esculentum \\
& (E=0) & (E=e-116) \\
\hline
\end{tabular}

${ }^{1}$ Propriedades avaliadas pelos programas de previsão PSORT e ExPASy. Similaridade: as proteínas $\beta$-1,3-glucanases codificadas por genes isolados de cafeeiro cv. Mundo Novo e Híbrido de Timor apresentaram, respectivamente, maior homologia com as seqüências provenientes de Arabidopsis thaliana ( $\mathrm{N}^{\circ}$ de acesso NP176656) e de Lycopersicon esculentum ( $\mathrm{n}^{\circ}$ de acesso S44365), depositadas no banco de dados. 


\section{DISCUSSÃO}

\subsection{Resistência sistêmica adquirida em cafeeiro contra $H$. vastatrix e indução local e sistêmica de quitinases e $\beta$-1,3-glucanases por acibenzolar-S-metil}

Aumentos nas atividades de PR-proteínas, tais como, $\beta$-1,3-glucanases e quitinases têm sido freqüentemente associados com os mecanismos de defesa de plantas (Boller, 1987), uma vez que podem ser induzidos por patógenos (Roulin \& Buchala, 1995), metabólitos ou componentes das paredes celulares de microrganismos (Kombrink \& Hahlbrock, 1986) ou substâncias químicas que agem como indutores de resistência (Kessmann et al., 1994). Enzimas hidrolíticas, como $\beta$-1,3-glucanases, podem, também, liberar oligossacarídeos das paredes celulares de fungos, os quais induzem, por sua vez, a produção de compostos de defesa em plantas, como, por exemplo, fitoalexinas (Okinaka et al., 1995). As PR-proteínas, incluindo essas hidrolases, têm sido particularmente associadas com a SAR ativada em diferentes interações hospedeiropatógeno (Pieterse et al., 2001a e Ryals et al., 1996). Em trabalho desenvolvido anteriormente, foi verificado que a SAR pôde ser ativada em cafeeiro suscetível cv. Mundo Novo após o tratamento com o composto acibenzolar-S-metil (ASM), conferindo proteção contra H. vastatrix (Guzzo et al., 2001). Como o desenvolvimento do patógeno nos estágios de pré-penetração (germinação de urediniosporos e formação de apressórios) não foi afetado pelo tratamento das folhas com o ASM, foi aventada a hipótese da proteção observada ser decorrente da ativação de mecanismos de defesa nas plantas, previamente tratadas com o indutor de resistência. O presente trabalho procurou, portanto, avaliar temporalmente, a indução de $\beta$-1,3-glucanases e quitinases em cafeeiro e sua relação com a SAR ativada no cultivar Mundo Novo, após o tratamento das plantas 
com acibenzolar-S-metil, visando identificar mecanismos bioquímicos de resistência, envolvidos na proteção observada contra a ferrugem alaranjada.

Os resultados obtidos neste trabalho revelaram que o ASM, na concentração de $200 \mu \mathrm{g}$ de i.a./mL, induziu aumento local e sistêmico das atividades de quitinases e $\beta$ 1,3-glucanases em folhas de plantas de café (Tabelas 2 e 3, Figura 3). O aumento de atividade de $\beta$-1,3-glucanases e/ou quitinases foi, também, observado em várias culturas após o tratamento com ASM, como por exemplo, batata (Bokshi et al., 2003), pepino (Narusaka et al., 1999), couve-flor (Ziadi et al., 2001), beterraba (Burketova et al., 1999) e roseira (Suo \& Leung, 2002). Bokshi et al. (2003) detectaram aumento da atividade de $\beta$-1,3-glucanase em folhas, caules e tubérculos de batata após o tratamento foliar das plantas com ASM na concentração de $100 \mathrm{mg}$ de i.a./L, em condições de casa de vegetação. Similarmente aos resultados obtidos no presente trabalho, os autores detectaram um aumento máximo de atividade de $\beta$-1,3-glucanase nos tecidos foliares 7 dias após o tratamento com o indutor. $\mathrm{O}$ aumento de atividade enzimática foi observado até 45 dias após a pulverização foliar com o produto. A síntese de $\beta$-1,3-glucanase foi, também, monitorada nos tecidos foliares de plantas pulverizadas no campo com o ASM, tendo sido observado um aumento de atividade enzimática até 4 semanas após o tratamento com o indutor. Os autores verificaram que as pulverizações foliares de plantas de batata com ASM em casa de vegetação resultaram na proteção quase completa contra A. solani e Erysiphe cichoracearum, agentes causais da pinta preta e oídio, respectivamente. O ASM também reduziu a severidade dessas doenças no campo. Bokshi et al. (2003) sugeriram que o aumento de atividade de $\beta$-1,3-glucanase observado nas plantas tratadas pode estar associado com a resistência induzida pelo produto.

Os resultados obtidos no presente estudo sugerem, também, que o aumento de atividade de $\beta$-1,3-glucanases e quitinases promovido pelo ASM está positivamente correlacionado com a resistência local e sistêmica, induzida por esse composto, em cafeeiro cv. Mundo Novo contra a ferrugem. Proteção local e sistêmica contra $H$. vastatrix foram induzidas em plantas de café a partir do primeiro dia após a aplicação do 
ASM nos terceiros pares de folhas, sendo detectadas durante um intervalo de tempo de até 35 dias entre a aplicação do indutor e a inoculação com o patógeno (Tabela 1). A proteção local contra a ferrugem, observada um dia após o tratamento com o ASM, atingiu um nível máximo (87 \%) entre 7 e 14 dias (Tabela 1). Similarmente, após um dia do tratamento de plantas de café com o indutor, pôde ser detectado um aumento significativo das atividades de $\beta$-1,3-glucanases e quitinases nos terceiros pares de folhas tratados com ASM, atingindo níveis máximos, também, após sete dias (Figura 3). A diferença de atividade enzimática entre plantas protegidas e plantas controle tornou-se maior à medida que a proteção aumentou (Figura 3). Níveis máximos de proteção sistêmica contra a ferrugem (53 a 68\%) foram observados nos segundos pares de folhas, entre 2 e 21 dias após o tratamento dos terceiros pares de folhas de plantas de café com o indutor (Tabela 1). Neste intervalo de tempo foi observado, também, um aumento sistêmico máximo de atividade enzimática (Figura 3). Quando o nível de proteção local e sistêmica diminuiu, as diferenças de atividades enzimáticas entre plantas induzidas à resistência e controle foram também reduzidas (Figura 3). Estudos desenvolvidos anteriormente, utilizando uma formulação comercial de B. thuringiensis como indutor de resistência, corroboram a hipótese de que o aumento de atividade dessas hidrolases observado em plantas tratadas está associado com a resistência local e sistêmica induzida em cafeeiro contra a ferrugem (Guzzo \& Martins, 1996). O tratamento prévio de plantas de café com $B$. thuringiensis promoveu uma indução de resistência local e sistêmica contra $H$. vastatrix associada com a síntese das PR-proteínas, $\beta$-1,3-glucanases e quitinases. Entretanto, um aumento significativo, local e sistêmico, de atividade enzimática foi observado somente 4 e 11 dias, respectivamente, após a aplicação do indutor, atingindo um nível máximo entre 18 e 21 dias após o tratamento (Guzzo \& Martins, 1996). A associação da SAR com a síntese de PR-proteínas ativadas pelo ASM foi bem estabelecida em outras culturas, como fumo e Arabidopsis, tendo sido constatado, que a identidade e os níveis de expressão dos genes codificadores dessas proteínas variaram entre as diferentes espécies vegetais (Friedrich et al., 1996 e Lawton et al., 1996). 
Similarmente, Suo \& Leung (2002) verificaram que o tratamento de roseiras com o ASM resultou em um aumento de proteção contra Diplocarpon rosae acompanhado pela indução e acúmulo de várias proteínas extracelulares identificadas como PR-proteínas das famílias PR-1, PR-2 ( $\beta$-1,3-glucanases), PR-3 (quitinases) e PR5 (taumatinas). Embora essas proteínas tenham sido também induzidas em plantas após a infecção com $D$. rosae, o acúmulo ocorreu mais rapidamente e de forma mais intensa nos tecidos foliares de plantas inoculadas com o patógeno, previamente tratadas com o ASM. Os autores sugeriram que essas PR-proteínas podem desempenhar um papel importante na restrição do desenvolvimento dos sintomas da doença causados por $D$. rosae. Resistência sistêmica contra C. cucumerinum e o acúmulo de quitinase foram, também, rapidamente induzidos em plantas de pepino após tratamento com acibenzolarS-metil (Narusaka et al., 1999). O acúmulo de quitinase em resposta à inoculação com o patógeno foi, também, induzido mais rapidamente em plantas pré-tratadas com o indutor (Narusaka et al., 1999).

A correlação do aumento das atividades de $\beta$-1,3-glucanases e/ou quitinases com a indução de resistência, observada em diferentes interações hospedeiro-patógeno indica que essas hidrolases podem desempenhar um papel relevante na restrição do desenvolvimento de fitopatógenos nas plantas previamente tratadas com indutores de resistência. A ação de $\beta-1,3$-glucanases e quitinases em plantas induzidas à resistência pode estar associada com o potencial antimicrobiano dessas PR-proteínas. Existem evidências tanto de sua ação antimicrobiana direta como indireta sobre fitopatógenos. Foi demonstrada a ação hidrolítica, in vitro, de $\beta$-1,3-glucanases e quitinases em paredes celulares de alguns fungos fitopatogênicos (Madamanchi \& Kuć, 1991). Três isoformas de $\beta$-1,3-glucanases isoladas de folhas de amendoim inoculadas com Cercospora arachidicola quando reunidas, in vitro, degradaram eficientemente a parede celular desse patógeno (Roulin \& Buchala, 1995). Young \& Pegg (1982), também, verificaram que $\beta$-1,3-glucanases isoladas de tomateiro, degradaram, in vitro, as paredes celulares de Verticillium albo-atrum, sendo que sua ação hidrolítica foi estimulada sinergisticamente por quitinases. Foi verificado, também, que uma $\beta-1,3$-glucanase isolada de caule de 
Capsicum annuum após indução pelo tratamento com cloreto de mercúrio, inibiu o crescimento das hifas do fungo Phytophthora capsici, que não contém quitina (Kim \& Hwang, 1997). Além disso, foi constatada uma ação sinergística da $\beta$-1,3-glucanase na inibição do crescimento das hifas de Fusarium oxysporum f.sp. cucumerinum e $P$. capsici, quando combinada com uma quitinase básica isolada de pimenta (Kim \& Hwang, 1997). Foi constatado, também, um aumento de resistência contra a infecção por bactérias e fungos pela co-expressão constitutiva de quitinases e $\beta$-1,3-glucanases em plantas transgênicas de fumo, evidenciando o potencial antimicrobiano in vivo dessas enzimas (Zhu et al., 1994).

Em cafeeiro, o acúmulo de quitinases e $\beta$-1,3-glucanases observado nos tecidos foliares do cultivar Mundo Novo, após o tratamento com indutores abiótico e biótico de resistência, como o acibenzolar-S-metil e B. thuringiensis, respectivamente, pode ser relevante para a proteção observada contra $H$. vastatrix. Martins (1988) e Martins \& Moraes (1996), constataram, através de estudos histológicos, que em plantas de café cv. Mundo Novo, induzidas à resistência pelo tratamento prévio com extrato de $S$. cerevisiae, houve uma redução de $80 \%$ no número de sítios de infecção por $\mathrm{cm}^{2}$ de tecido foliar, $72 \mathrm{~h}$ após a inoculação com $H$. vastatrix. Após esse intervalo de tempo, 80 \% das colônias não puderam mais ser visualizadas pelas técnicas utilizadas, sugerindo ter ocorrido profundas alterações nas estruturas do fungo, que não foram acompanhadas de reação de necrosamento das células do hospedeiro. Foi aventada a hipótese de ter ocorrido lise das estruturas do fungo formadas na cavidade sub-estomática, pela ação de enzimas envolvidas nos mecanismos de resistência, acarretando o desaparecimento das colônias do patógeno nas plantas induzidas (Martins, 1988). Por outro lado, Silva et al. (1999) e Guerra-Guimarães et al. (2001) constataram que as paredes das hifas intercelulares e os haustórios de $H$. vastatrix contêm $\beta$-1,3-glucanas e resíduos de Nacetilglucosamina, monômeros formadores de quitina. Pode-se aventar a possibilidade, com base nos resultados aqui obtidos e nas observações descritas por esses autores, de que as enzimas hidrolíticas, $\beta$-1,3-glucanases e quitinases, podem ter um papel relevante na restrição do desenvolvimento do patógeno nas plantas de café induzidas à resistência, 
possivelmente devido ao seu potencial antimicrobiano, degradando as estruturas de infecção de $H$. vastatrix.

\subsection{Genes de cafeeiro cv. Mundo Novo, associados à resistência sistêmica adquirida e de cafeeiro Híbrido de Timor associados à resistência vertical}

\subsubsection{Genes isolados de cafeeiro cv. Mundo Novo tratado com o indutor de resistência acibenzolar-S-metil}

A técnica de hibridização subtrativa por supressão (HSS) permitiu isolar de cafeeiro suscetível cv. Mundo Novo, $72 \mathrm{~h}$ após o tratamento com o indutor de resistência ASM, genes implicados no estresse oxidativo, na resposta de hipersensibilidade ou na morte celular programada (Tabela 4).

A resposta de hipersensibilidade ativada em plantas poucas horas após o contacto com o patógeno no sítio de penetração ou após o tratamento com indutores bióticos ou abióticos, envolve, desde a morte de uma ou poucas células do hospedeiro até a formação de áreas necróticas. A morte celular localizada é acompanhada pela indução de respostas de defesa e pela colonização limitada de fitopatógenos nos tecidos vegetais (Hammond-Kosack \& Jones, 1996). A resposta de hipersensibilidade pode ocorrer como conseqüência da ativação de vias bioquímicas que levam à formação de radicais livres e outros compostos tóxicos, não apenas ao patógeno, mas também à planta, provocando a morte rápida das células vegetais (Hammond-Kosack \& Jones, 1996). Por outro lado, pode ocorrer uma morte celular programada acionada pela planta ao reconhecer a presença do patógeno (Heath, 2000 e Lam et al., 2001). As células vegetais atacadas iniciam a execução de um programa de morte celular como defesa, no sítio inicial de infecção, podendo privar patógenos do acesso a nutrientes ou liberar substâncias inibidoras pré-formadas estocadas no vacúolo ou, ainda, sinalizar a indução de respostas de resistência na planta. Existem evidências da ocorrência dos dois tipos de resposta de hipersensibilidade durante a defesa do hospedeiro (Hammond-Kosack \& Jones, 1996). A morte celular programada em plantas está envolvida, também, em outros 
processos, como, reprodução, senescência, amadurecimento de frutos e apresenta algumas características morfológicas e bioquímicas semelhantes às células animais, que podem incluir a contração do citoplasma, condensação do núcleo, modificação da membrana plasmática, alteração no fluxo de íons cálcio, fragmentação do DNA e ativação de proteases específicas (Lam et al., 2001 e Solomon et al., 1999). Entre estas, as cisteína proteases, têm sido implicadas como mediadoras da morte celular induzida em tecidos vegetais por patógenos ou por estresse oxidativo (Solomon et al., 1999). Em cultura de células de soja em suspensão, o estresse oxidativo estimulado pela aplicação de peróxido de hidrogênio, induziu a morte celular programada e a síntese de um conjunto de cisteína proteases, as quais foram capazes de digerir substratos específicos para papaína. A atividade de uma ou mais proteases foi necessária para a mediação da morte celular programada em células de soja. Inibidores específicos de cisteína proteases sintéticos inibiram a atividade das proteases induzidas por estresse oxidativo em soja. A expressão constitutiva em soja, de gene isolado dessa mesma planta, codificador de um inibidor de cisteína protease, do tipo cistatina, inibiu a atividade das cisteína proteases induzidas nos tecidos vegetais e bloqueou, simultaneamente, a morte celular programada, desencadeada por um isolado avirulento de $P$. syringae pv. glycinea ou diretamente, por estresse oxidativo (Solomon et al., 1999). No presente estudo, foi possível isolar de cafeeiro cv. Mundo Novo três clones de cDNA que apresentaram similaridade com cisteína proteases isoladas de A. thaliana, Ipomoea batatas e Phaseolus vulgaris (Tabela 4). As seqüências de cafeeiro apresentaram, também, domínios de cisteína protease da família papaína. A expressão desses genes foi também observada em outras plantas após o tratamento com indutores de resistência ou inoculação com patógenos, podendo estar relacionada à resposta de hipersensibilidade. A resistência genética em batata contra $P$. infestans, o agente causal da requeima, é caracterizada pela reação de hipersensibilidade. Birch et al. (1999), visando determinar os primeiros eventos associados à resposta de hipersensibilidade em batata contra $P$. infestans isolaram por HSS, genes codificadores de cisteína proteases, $24 \mathrm{~h}$ após a inoculação das plantas com esse patógeno. 
A produção de espécies reativas de oxigênio (ROS), como o ânion superóxido $\left(\mathrm{O}_{2}^{-}\right)$e o peróxido de hidrogênio $\left(\mathrm{H}_{2} \mathrm{O}_{2}\right)$, é freqüentemente uma das primeiras respostas de defesa ativadas em plantas e pode ser responsável por desencadear o início da resposta de hipersensibilidade (Grant \& Loake, 2000 e Heath, 2000). A enzima superóxido dismutase cobre/zinco (SOD) é responsável pela síntese de peróxido de hidrogênio e oxigênio molecular, a partir do ânion superóxido. O peróxido de hidrogênio formado, além de ser diretamente tóxico a microrganismos, pode dar origem a outros radicais livres mais reativos, como o radical hidroxila $\left(\mathrm{OH}^{\circ}\right)$, que irá iniciar a peroxidação de lipídeos, danificando a membrana plasmática vegetal (Grant \& Loake, 2000). Os peróxidos de lipídeos formados são tóxicos a microrganismos e se constituem em moléculas sinalizadoras de vias de defesa, como também o $\mathrm{H}_{2} \mathrm{O}_{2}$, podendo ativar, por exemplo, a síntese de ácido salicílico (Leon et al., 1995 e Martinez et al., 2000). Além desse aspecto, foi demonstrada a ação de peróxidos de lipídeos como potentes indutores da morte celular programada em protoplastos de tomate, aumentando a fragmentação do DNA da célula vegetal (Knight et al., 2001). O peróxido de hidrogênio pode, também, contribuir para o fortalecimento da parede celular vegetal, participando da síntese de lignina pela ação de peroxidases ou da interligação oxidativa de glicoproteínas ricas em hidroxiprolina já presentes na parede celular vegetal (Borden \& Higgins, 2002; Hammond-Kosack \& Jones, 1996 e Shetty et al., 2003). Esses processos podem conferir à parede celular vegetal, resistência à penetração de patógenos e à degradação por enzimas hidrolíticas secretadas por microrganismos, como pectinases, celulases e poligalacturonases. As espécies reativas de oxigênio podem, também, ativar a expressão de genes de defesa em células adjacentes e nos tecidos vegetais distantes do local de produção de ROS, provavelmente em conjunto com outras moléculas sinalizadoras (Wan et al., 2002). Desikan et al. (2001) estudando a expressão de genes em Arabidopsis sob estresse oxidativo, identificaram vários genes regulados por $\mathrm{H}_{2} \mathrm{O}_{2}$. Esse composto induziu a expressão de genes de defesa como, lipoxigenase, peroxidase, quinases e fatores de transcrição. No presente estudo, a identificação de dois clones de cDNA de gene codificador da enzima SOD em cafeeiro, após o tratamento com o composto ASM, sugere que houve a formação nos tecidos vegetais, de espécies reativas 
de oxigênio, como o ânion superóxido e o peróxido de hidrogênio, durante a resposta de resistência induzida (Tabela 4).

A produção de ROS pode resultar em um dano considerável não apenas para o patógeno, mas também, para o hospedeiro e requer, que as células vegetais ativem um conjunto de mecanismos de proteção (Breusegem et al., 2001 e Hammond-Kosack \& Jones, 1996). Após a produção de ROS pode ocorrer a transcrição de genes codificadores de enzimas antioxidantes nos tecidos adjacentes ao sítio de infecção, como a catalase, glutationa-S-transferase (GST) e ascorbato peroxidase, as quais puderam ser identificadas em cafeeiro tratado com ASM (Tabela 4). Essas enzimas minimizam as conseqüências deletérias do estresse oxidativo e fazem parte de mecanismos específicos de proteção celular, os quais podem ser ativados em plantas, acompanhando as respostas de defesa. A GST, por exemplo, destoxifica os produtos de peroxidação de lipídeos da membrana e outros produtos de estresse celular oxidativo. A catalase e a ascorbato peroxidase protegem as células vegetais dos efeitos tóxicos do peróxido de hidrogênio, convertendo esse composto em água. Enquanto que a catalase elimina a maior parte ou porção livre de $\mathrm{H}_{2} \mathrm{O}_{2}$, a ascorbato peroxidase remove esse composto dos tecidos vegetais nos locais inacessíveis à catalase, devido a sua alta afinidade por $\mathrm{H}_{2} \mathrm{O}_{2}$ e à sua presença em diferentes localizações sub-celulares (Breusegem et al., 2001). Tem sido observado em algumas interações planta-patógeno, que a reação de hipersensibilidade é acompanhada pelo acúmulo dessas enzimas antioxidantes nos tecidos adjacentes, restringindo o tamanho das lesões necróticas causadas por essa resposta e confinando o patógeno no sítio de infecção (Hammond-Kosack \& Jones, 1996 e Shetty et al., 2003). A expressão de gene codificador de ascorbato peroxidase foi intensamente induzida durante a resposta de hipersensibilidade em plantas de fumo infectadas com o TMV. A ativação da expressão desse gene ocorreu depois de determinados eventos de sinalização tais como, mudanças na fosforilação de proteínas e indução de fluxos de íons, sendo controlada pela via de transdução de sinal da resposta de hipersensibilidade (Mittler et al., 1999). Shetty et al. (2003) observaram em um cultivar resistente de trigo inoculado com Septoria tritici, um acúmulo de $\mathrm{H}_{2} \mathrm{O}_{2}$, que foi correlacionado com a limitação do desenvolvimento desse patógeno nos tecidos vegetais. Através dos padrões de aumento 
na expressão de gene codificador de catalase e na atividade enzimática foi possível inferir que a catalase teve um papel regulador no acúmulo de $\mathrm{H}_{2} \mathrm{O}_{2}$ durante a resposta de resistência ativada nas plantas. Do et al. (2003), também, verificaram que a ativação da expressão de gene codificador de ascorbato peroxidase, pode funcionar na regulação do nível de $\mathrm{H}_{2} \mathrm{O}_{2}$ produzido no estresse oxidativo durante a resposta de hipersensibilidade, ativada na interação incompatível Capsicum annuum-Xanthomonas campestris pv. vesicatoria. A morte celular induzida em Betula pendula, após a inoculação com a bactéria incompatível Pseudomonas syringae pv. syringae ou estresse abiótico, foi precedida e acompanhada por um acúmulo de $\mathrm{H}_{2} \mathrm{O}_{2}$ e pelo aumento na expressão de genes codificadores de SOD e das enzimas antioxidantes ascorbato peroxidase e glutationa-S-transferase (Pellinen et al., 2002). Aumentos na expressão de genes envolvidos no estresse oxidativo e na reação de hipersensibilidade, incluindo a cisteína protease, SOD, GST e ascorbato peroxidase foram, também, observados em outras plantas, como por exemplo, em cevada, após a inoculação com B. graminis f.sp. hordei (Huckelhoven et al., 2001) e em A. thaliana após inoculação com o patógeno incompatível $A$. brassicicola ou tratamento com ácido salicílico e/ou metil jasmonato (Schenk et al., 2000).

A ativação da SAR em plantas, normalmente, está relacionada com a resposta de hipersensibilidade. Alvarez et al. (1998) observaram que a resposta de hipersensibilidade ativada em $A$. thaliana após a inoculação com um patógeno bacteriano avirulento, $P$. syringae pv. tomato ou devido à indução da produção de $\mathrm{H}_{2} \mathrm{O}_{2}$ nos tecidos vegetais, foi correlacionada com a expressão de genes de defesa como GST e $P R-2$ e precedeu o estabelecimento da SAR. Em cafeeiro, foi possível isolar genes codificadores de cisteína protease, superóxido dismutase, ascorbato peroxidase, glutationaS-transferase e catalase, após o tratamento com o composto ASM, um indutor abiótico da SAR (Tabela 4). Os resultados obtidos no presente trabalho sugerem que durante a resposta de resistência induzida em cafeeiro suscetível pelo indutor abiótico ASM, ocorreu ativação da resposta de hipersensibilidade, com a produção de espécies reativas de oxigênio e ativação de enzimas antioxidantes como mecanismo de proteção celular. 
Em cafeeiro suscetível cv. Mundo Novo tratado com ASM foi possível isolar, através da HSS, genes codificadores de compostos antimicrobianos, como a proteína principal do látex, quitinases, $\beta$-1,3-glucanase, inibidores de cisteína proteinases (tipo cistatinas) e aspártico protease (Tabela 5).

As aspártico proteinases de plantas são uma família de endoproteases, que podem estar envolvidas em diferentes processos fisiológicos, onde a degradação protéica é requerida, como senescência, germinação de sementes e morte celular programada. $\mathrm{O}$ clone de cDNA isolado de cafeeiro Mundo Novo apresentou similaridade com a aspártico protease, tipo nucelina, de A. thaliana (Tabela 5). Por outro lado, as aspártico proteinases têm sido implicadas, também, na defesa de plantas contra insetos herbívoros e fitopatógenos, podendo hidrolisar proteínas secretadas por esses organismos. Como a lise de paredes celulares de microrganismos pode requerer a degradação das proteínas da parede celular, além da hidrólise de quitinas, glucanas e outros compostos, as endoproteases podem agir, também, como um mecanismo complementar para a degradação das estruturas de infecção de fitopatógenos durante a patogênese. Evidências dessas funções para proteases de plantas foram obtidas por Guevara et al. (2002) e Schaller \& Ryan (1996). Guevara et al. (2002) purificaram uma aspártico protease de folhas e tubérculos de batata. O perfil de indução da proteína, em resposta a ferimento ou à infecção causada por $P$. infestans, foi analisado nos lavados intercelulares de discos de tubérculos de dois cultivares de batata, diferindo na sua suscetibilidade contra esse patógeno. Foi observada uma indução rápida e mais intensa no cultivar resistente do que no suscetível, onde o acúmulo da endoprotease ocorreu de forma tardia. A aspártico protease apresentou, também, um efeito inibidor direto in vitro na germinação de $P$. infestans e Fusarium solani. Schaller \& Ryan (1996) isolaram um clone de cDNA codificador de aspártico protease a partir de tecido foliar de plantas de tomate. Foi observado um aumento local e sistêmico na expressão desse gene nos tecidos foliares das plantas, após ferimento causado por injúria mecânica ou tratamento com metil jasmonato ou sistemina. A indução da expressão de aspártico protease foi regulada por sistemina, ocorrendo de forma similar a outras proteínas, que se acumulam sistemicamente em resposta a ferimentos e fazem parte da resposta de defesa em plantas 
de tomate direcionada contra o ataque por herbívoros. O peptídeo sistemina é sintetizado nos tecidos vegetais, como conseqüência de ferimentos em plantas ocasionados por injúria mecânica ou ataque por herbívoros. A sistemina é translocada via floema e sua percepção no tecido foliar leva à hidrólise de fosfolipídeos da membrana celular vegetal, com a conseqüente liberação do ácido linolênico. Este composto é rapidamente metabolizado em ácido jasmônico, o qual ativa a transcrição de genes codificadores de inibidores de proteinase e de proteases (Farmer \& Ryan, 1992; Ryan, 2000 e Heil \& Bostock, 2002). Resultados obtidos no presente estudo sugerem que essa via metabólica foi ativada em cafeeiro, após o tratamento com o indutor de resistência ASM. Além do isolamento de dois clones de cDNA codificadores de inibidores de proteinase, foi possível isolar por HSS, genes codificadores da aleno óxido sintase (AOS), enzima que catalisa a primeira reação específica na biossíntese de ácido jasmônico (AJ), e da proteína ácido jasmônico 2 , reguladora específica da via sinalizadora mediada por AJ em plantas (Tabela 7). Os clones de cDNA de cafeeiro Mundo Novo apresentaram similaridade com genes isolados de plantas de tomate (Tabela 7). O regulador vegetal AJ desempenha um importante papel na resistência contra insetos herbívoros e patógenos, agindo como uma molécula sinalizadora, podendo ativar em plantas, a expressão não apenas de proteases e inibidores de proteases, como também, de PR-proteínas com propriedades antimicrobianas, tais como a osmotina, tioninas e defensinas ou induzir acúmulo de enzimas relacionadas à síntese de fitoalexinas, como a chalcona sintase (Wasternack \& Parthier, 1997). Ziegler et al. (2001) verificaram que o tratamento exógeno de plantas de Nicotiana attenuata com AJ confere resistência contra Manduca sexta e outros herbívoros. Foi observado um aumento na expressão de AOS, que contribuiu para a manutenção de níveis endógenos mais altos de $\mathrm{AJ}$ nas plantas durante a defesa de $N$. attenuata contra herbívoros. O clone isolado de Mundo Novo apresentou maior similaridade com clone de cDNA de gene codificador de AOS isolado de tomateiro (Sivasankar et al., 2000). A AOS de tomate foi induzida em folhas, por ferimento, sistemina e metil jasmonato. Os autores verificaram que a síntese dessa enzima é determinante para a ativação de genes de defesa em tomate, como aquele 
codificador de inibidor de proteinase PIN II, pertencente à família de PR-proteínas, PR-6 (Sivasankar et al., 2000).

As proteínas inibidoras de proteinase formam um complexo com proteases, inibindo sua atividade enzimática proteolítica e estão envolvidas na defesa contra insetos, microrganismos e nematóides. O papel dos inibidores de proteinases na defesa de plantas contra o ataque por herbívoros é bem estabelecido. Estas proteínas, induzidas por ferimentos em folhas de plantas, ao serem ingeridas por insetos polífagos, interagem com proteases do trato intestinal e acarretam uma inibição no seu crescimento e desenvolvimento, podendo, ocasionalmente, levar à morte de herbívoros (Ryan, 1990). Inibidores de proteinase isolados de tomateiro, por exemplo, protegem as plantas contra serina proteinases digestivas de insetos herbívoros (Farmer e Ryan 1992 e Koiwa et al., 1997). Além do envolvimento na defesa de plantas contra herbívoros, os inibidores de proteinase, como as cistatinas, podem apresentar atividade antimicrobiana e também inibir proteases secretadas por fungos fitopatogênicos. Os dois clones de cDNA codificadores de inibidores de proteinase de cafeeiro apresentaram similaridade com os inibidores de cisteína proteinase, tipo cistatina, isolados de Citrus paradisi e A. thaliana e apresentaram também domínios de cistatina (Tabela 5). Pernas et al. (1999) verificaram que uma cistatina purificada de castanha inibiu o crescimento dos fungos fitopatogênicos B. cinerea, C. graminicola e Septoria nodorum, mas não do saprófita Trichoderma viride. Além disso, a cistatina afetou intensamente a atividade de protease de $B$. cinerea, mas não apresentou efeito sobre a atividade proteolítica de $T$. viride. Por outro lado, como as cistatinas agem especificamente sobre cisteína proteases, poderiam ter uma função adicional, agindo como moduladores da morte celular programada em plantas, inibindo a atividade dessas proteases, como foi verificado em plantas de soja (Solomon et al., 1999).

Foram isolados de cafeeiro Mundo Novo dois clones de cDNA que apresentaram similaridade com gene de videira, codificador de uma proteína principal do látex (MLP) (Tabela 5). A expressão de gene codificador de MLP em videira foi correlacionada com o amadurecimento de frutos (Davies \& Robinson, 2000). As MLPs são um grupo diverso de proteínas de baixo peso molecular relacionadas às proteínas do 
látex e aos alérgenos de pólen, que podem apresentar atividade antimicrobiana. Existem relatos na literatura da indução de MLPs em plantas em resposta a ferimentos ou ao tratamento com etileno e de seu envolvimento na resistência contra patógenos (Davies \& Robinson, 2000). Aumento na expressão de gene codificador de MLP foi, também, observado em A. thaliana, após inoculação com o patógeno incompatível A. brassicicola (Schenk et al., 2000). AS MLPs são, também, relacionadas a um grupo de PR-proteínas da família PR-10. As proteínas da família PR-10, por sua vez, apresentam alta homologia estrutural com as ribonucleases e são homólogas a uma grande família de alérgenos de pólen de plantas, como a Bet v I, um alérgeno presente em grãos de pólen de bétula (Betula verrucosa) que apresenta atividade de RNase in vitro (Bufe et al., 1996; Van Loon \& Van Strien, 1999). As seqüências de cafeeiro isoladas no presente estudo apresentaram o domínio Bet v I (pfam00407), característico da família Bet v I, proteína relacionada à patogênese, pertencente à família PR-10. Os resultados sugerem que os clones de cDNA isolados de cafeeiro após o tratamento com o indutor ASM, codificam uma proteína similar à proteína principal do látex e à família Bet v I, pertencente à família de PR-proteínas, PR-10. A expressão de genes codificadores de PR-10 associada à resistência induzida ou a outros mecanismos de defesa foram observados em plantas de maçã ou bétula, respectivamente. $\mathrm{O}$ acúmulo de $\mathrm{H}_{2} \mathrm{O}_{2}$ detectado em bétula, após a inoculação com a bactéria incompatível $P$. syringae pv. syringae ou estresse abiótico, foi acompanhado pela indução de genes codificadores de enzimas antioxidantes e do gene Ypr 10 , codificador de proteína Bet v I, da família PR10 (Pellinen et al., 2002). Ziadi et al. (2001) detectaram a expressão local e sistêmica de genes codificadores de PR-10 em folhas de plântulas de maçã, após tratamento com o composto ASM, o qual induziu resistência em plântulas de maçã contra E. amylovora (Ziadi et al., 2001).

Foram isolados de cafeeiro Mundo Novo cinco clones de cDNA de genes codificadores de quitinases e um clone de $\beta$-1,3-glucanase, os quais foram induzidos após o tratamento com ASM. Entretanto, a expressão do clone MN-HSS3-B12, que apresentou maior similaridade com gene de endoquitinase isolada de Castanea sativa, foi, também, detectada nas plantas não tratadas com o indutor de resistência, sugerindo 
que essa quitinase não é induzida especificamente pelo ASM (Figura 8 e Tabela 5). Através da pesquisa de domínios conservados e da análise do programa BlastX, pode-se inferir que foram ativadas pelo ASM, uma quitinase básica da classe I, pertencente à família 19 de gicosil hidrolases (MN-HSS4-E01), uma quitinase acídica da família 18 de gicosil hidrolases (MN-HSS1-A01), uma quitinase da classe III pertencente à família 18 de gicosil hidrolases (MN-HSS1-F10), uma quitinase acídica da classe III (MN-HSS1H05) e uma $\beta$-1,3-glucanase da família 17 de glicosil hidrolases (MN-HSS2-B03) (Tabela 5). As quitinases da classe III podem apresentar atividade adicional de lisozima, importante na defesa de plantas contra bactérias fitopatogênicas. A expressão de genes codificadores dessas hidrolases e de outras PR-proteínas foi detectada em várias plantas, após tratamento com indutores de resistência bióticos e abióticos, sendo associada com a expressão da SAR em diferentes plantas, como fumo (Friedrich et al., 1996) e Arabidopsis (Lawton et al., 1996). Os resultados do presente trabalho, indicando que o ASM induziu em cafeeiro suscetível, aumento local e sistêmico de atividade de quitinases e $\beta$-1,3-glucanases, detectados através de ensaios enzimáticos, e também, a expressão de cinco clones de genes codificadores dessas hidrolases, $72 \mathrm{~h}$ após o tratamento das folhas com o indutor de resistência, reforçam a hipótese de que essas PRproteínas podem ter uma função importante na restrição do desenvolvimento de $H$. vastatrix, hidrolisando as estruturas de infecção do fungo. O ASM não afeta as fases de pré-penetração do patógeno em cafeeiro Mundo Novo, incluindo a germinação e formação de apressórios (Guzzo et al., 2001). Essa observação sugere que o fungo é inibido posteriormente, quando já inicia seu desenvolvimento nos espaços intercelulares do tecido vegetal. Nessa etapa, a ação de proteínas antimicrobianas sobre o patógeno como as PR-proteínas, quitinases, $\beta$-1,3-glucanases, inibidores de proteinase (tipo cistatinas) e a MLP, que apresentou domínio da proteína Bet v I, pertencente à família PR-10, poderia resultar na restrição do desenvolvimento de $H$. vastatrix nos tecidos das plantas de café induzidas à resistência. Não foi detectada em cafeeiro, a indução da expressão de genes codificadores de PR-proteínas, da família PR-1, que são marcadores moleculares da SAR em fumo e Arabidopsis (Ryals et al., 1996). As proteínas PR-1 fazem parte de um grupo dominante de PR-proteínas, que se acumulam mais 
abundantemente nos tecidos vegetais após infecção por patógenos e apresentam atividade antifúngica. Estudos demonstraram que as proteínas PR-1 não apresentam atividade inibidora de proteinase ou outra atividade enzimática e são insensíveis a várias proteases (Van Loon \& Van Strien, 1999). No presente estudo, não foram detectados, também, genes de PR-proteínas tais como a osmotina, tioninas e defensinas que possuem propriedades antimicrobianas e são normalmente ativadas por ácido jasmônico (Wasternack \& Parthier, 1997). Entretanto, foram detectados em cafeeiro os inibidores de proteinase, que são normalmente ativados por esse regulador vegetal, sugerindo que a expressão de genes codificadores de PR-proteínas pode estar, também, relacionada com a espécie vegetal. De fato, foi observado que a identidade e os níveis de expressão dos genes marcadores da SAR varia entre as diferentes espécies vegetais (Besser et al., 2000; Friedrich et al., 1996 e Lawton et al., 1996). Os resultados obtidos no presente trabalho indicam que durante a resposta de resistência induzida em cafeeiro suscetível pelo indutor abiótico ASM, ocorreu ativação de vários genes codificadores de proteínas antimicrobianas, relacionadas às diferentes famílias de PR-proteínas, as quais podem desempenhar um papel importante na restrição do desenvolvimento de fitopatógenos. Os dados obtidos sugerem, também, que em cafeeiro, como já verificado para outras plantas, a indução de genes codificadores de PR-proteínas, pode estar associada com a contenção do patógeno e a expressão da SAR.

A detecção em cafeeiro suscetível cv. Mundo Novo, de dois clones de genes codificadores da enzima CAD, $72 \mathrm{~h}$ após o tratamento com o indutor de resistência ASM, sugere que pode ter ocorrido síntese e depósito de lignina nas paredes celulares nas plantas tratadas (Tabela 6). O fortalecimento da parede da célula vegetal pelo depósito de lignina poderia dificultar a formação de haustórios de $H$. vastatrix dentro da célula hospedeira e a troca de nutrientes. Os monolignóis, constituídos por álcoois cinâmicos, formados pela atividade catalítica da CAD possuem, também, atividade antimicrobiana e podem inativar toxinas ou enzimas hidrolíticas secretadas por fitopatógenos. A chalcona sintase catalisa a primeira etapa na biossíntese dos flavonóides, especificamente a subclasse das chalconas, enquanto que a flavanona-3hidroxilase catalisa o primeiro passo para a síntese dos flavonóis a partir das flavanonas. 
O composto ASM induziu a expressão de genes em cafeeiro Mundo Novo, que apresentaram similaridade com genes codificadores dessas enzimas, isolados de Camellia sinensis e A. thaliana. Muitos flavonóides são antimicrobianos e várias fitoalexinas caracterizadas em diferentes plantas pertencem a essa classe de compostos químicos. Lo et al. (1999) realizaram um estudo do padrão da expressão de genes codificadores da PR-10 e de chalcona sintase, envolvida na síntese de fitoalexina do sorgo, em plântulas inoculadas com C. heterostrophus, um fungo não patogênico ao sorgo. Foi observado um acúmulo rápido de mRNAs de PR-10 e chalcona sintase nas plântulas no sítio de inoculação, após o desenvolvimento de apressórios do fungo, sendo acompanhado pelo acúmulo de fitoalexinas. $\mathrm{O}$ acúmulo de mRNAs e fitoalexinas foi fortemente correlacionado com a resposta de resistência contra C. heterostrophus. A expressão da SAR em algumas plantas foi também associada com a síntese de fitoalexinas (Hwang et al., 1997 e Latunde-Dada \& Lucas, 2001). Foi detectado, também, em cafeeiro, um clone de cDNA que apresentou similaridade com gene codificador de uma proteína transportadora $\mathrm{ABC}$, que pode estar envolvida na secreção ou no transporte de compostos tóxicos do metabolismo secundário (Tabela 6). $\mathrm{O}$ isolamento desses genes em cafeeiro após o tratamento com ASM, sugere que pode ter ocorrido ativação de vias metabólicas do metabolismo secundário, durante a resposta de resistência induzida.

Além do isolamento dos genes codificadores da enzima AOS e da proteína jasmônico 2, relacionados à síntese e à via metabólica regulada por ácido jasmônico, foram detectados no cultivar Mundo Novo tratado com ASM, três clones de cDNA, que apresentaram similaridade com genes codificadores de SAM sintetase, enzima que participa do ciclo de Yang (ciclo da metionina), catalisando a formação de Sadenosilmetionina (SAM) a partir de metionina. O composto SAM, por sua vez, através de reação catalisada pela enzima ACC sintase, dá origem ao precursor imediato do etileno. Além de seu papel na produção de etileno, a SAM está envolvida na biossíntese de poliaminas. Foi isolado, também, um clone de cDNA codificador de arginina descarboxilase, que catalisa a reação para a biossíntese de poliaminas, a partir de arginina (Tabela 7). Esses resultados sugerem que o ASM pode ter induzido em cafeeiro, 
a síntese de etileno e de poliaminas. O ácido jasmônico, o etileno e poliaminas, além de participarem de processos relacionados ao desenvolvimento vegetal, têm sido implicados, juntamente com o ácido salicílico, na regulação de respostas de resistência em plantas contra doenças. Em muitos casos, a infecção em plantas por patógenos microbianos ou ataque por herbívoros estão associadas com aumento de produção desses reguladores vegetais e ativação concomitante de grupos distintos de genes relacionados à defesa (Schenk et al., 2000). Além disso, a aplicação exógena de ácido jasmônico, etileno e ácido salić́lico, resultam, freqüentemente, em um aumento no nível de resistência. Outras evidências da participação desses compostos nas respostas de defesa foram obtidas por experimentos efetuados com plantas mutantes ou transgênicas (Pieterse et al., 2001a). As poliaminas e respectivos conjugados têm sido implicadas na indução de resistência e na resposta de hipersensibilidade contra infecção causada por fitopatógenos. Foram observados aumentos significativos nos níveis das poliaminas, putrescina e espermina e dos respectivos conjugados solúveis, em tecido foliar de plantas de cevada tratadas previamente com metil jasmonato. $\mathrm{O}$ tratamento induziu simultaneamente um aumento na atividade de arginina descarboxilase e proteção sistêmica em cevada contra o oídio, causado por B. graminis f. sp. hordei (Walters et al., 2002).

A expressão da resistência induzida em plantas implica na ativação de mecanismos iniciais de percepção e transdução de sinais, que vão sinalizar a célula vegetal para induzir a expressão de genes e síntese subseqüente de compostos de defesa. O indutor de resistência ASM ativou em cafeeiro suscetível a expressão de genes codificadores de várias proteínas implicadas nos mecanismos de percepção e transdução de sinal. Entre estes, foram isoladas por HSS, clones de cDNA que apresentaram similaridade com uma proteína de ligação à calmodulina, uma quinase tipo CIPK capaz de interagir com proteína calcineurina $\mathrm{B}$ sensora de cálcio, uma fosfatase $2 \mathrm{~A}$, duas proteínas serina treonina quinases, duas quinases receptoras tipo lectina que se ligam a carboidratos e uma proteína com repetições ricas em leucina (Tabela 8). As quinases tipo receptoras (RLKs) se constituem em um grupo importante de proteínas dímeras localizadas na membrana celular vegetal, que possuem um domínio extracelular e 
apresentam uma função direta na transmissão de sinais extracelulares através da membrana plasmática. Quando ocorre a ligação do domínio extracelular com um sinal externo à célula vegetal, a proteína sofre uma reação de dimerização, que resulta na autofosforilação do domínio de quinase intracelular localizado no citoplasma, transmitindo, subseqüentemente, essa informação para a célula vegetal. As RLKs possuem domínio extracelular variado, que pode ser constituído, por exemplo, de repetições ricas em leucina (LRR), capaz de se ligar a sinais constituídos por moléculas protéicas, ou de lectina, capaz de se ligar a carboidratos. As RLKs de plantas podem possuir, também, domínio extracelular similar às glicoproteínas do locus $\mathrm{S}$, relacionadas à incompatibilidade esporofítica do gênero Brassica (Trewavas, 2000). As quinases receptoras, tipo lectina encontradas em café, poderiam ter um papel na percepção de sinais constituídos por moléculas de carboidratos ou oligossacarídeos, como por exemplo, fragmentos da parede celular e das estruturas de infecção de fitopatógenos. Uma das primeiras modificações que ocorrem associadas às respostas de resistência em plantas consiste de alterações na concentração de íons cálcio na célula vegetal (Hammond-Kosack \& Jones, 1996 e Zuppini et al., 2004). Esses aumentos de concentração podem ser detectados por proteínas, como a calmodulina, que apresenta sítios específicos de ligação ao cálcio ou por proteínas tipo calcineurina B. Após a ligação com íons cálcio, essas proteínas são ativadas, através de mudanças na sua conformação e função, sendo subseqüentemente reconhecidas por outras proteínas na célula vegetal. Proteínas de ligação à calmodulina, como a glutamato descarboxilase (GAD) ou quinases, denominadas CIPK, que interagem com proteína tipo calcineurina B, sensora de íons cálcio, podem transmitir essa informação nas células do hospedeiro. O clone de cDNA de cafeeiro, MN-HSS1-A10, apresentou maior similaridade com a proteína CIPK 11 de $A$. thaliana, membro de uma família de quinases, que interagem com proteínas tipo calcineurina B isoladas da mesma planta, as quais são induzidas em resposta a diferentes tipos de estresse (Kim et al., 2000). Ali et al. (2003) isolaram de uma biblioteca de cDNA produzida a partir de folhas de feijão sob a resposta de hipersensibilidade, oito clones de genes codificadores de proteínas de ligação à calmodulina. Analisando a expressão em folhas de feijão inoculadas com isolados 
bacterianos virulentos e avirulentos verificaram um aumento da expressão desses genes em resposta aos patógenos incompatíveis. Os genes foram associados com a indução de respostas de defesa, sendo, também, ativados após o tratamento com, ácido salicílico, ácido jasmônico, $\mathrm{H}_{2} \mathrm{O}_{2}$ e um elicitor de respostas de defesa isolado de fungo. No presente trabalho, a ativação em cafeeiro pelo indutor de resistência ASM, de genes codificadores de proteína de ligação à calmodulina (GAD) e de quinase tipo CIPK, sugere que mecanismos regulados por esses genes podem ter sido ativados na resistência induzida no cultivar Mundo Novo. Aumentos na expressão de genes codificadores de quinases, quinases tipo receptoras e fosfatases foram, também, observados em outras plantas, como por exemplo, em A. thaliana após inoculação com o patógeno incompatível A. brassicicola ou tratamento com ácido salicílico e/ou metil jasmonato (Schenk et al., 2000). Foi induzido em cafeeiro pelo tratamento com o indutor de resistência ASM, um clone de cDNA, que mostrou maior similaridade com gene codificador de proteína de resistência a doenças com repetições ricas em leucina isolado de A. thaliana, e apresentou, também, domínio LRR. Foi isolado de fumo um gene codificador de uma proteína LRR, que foi expresso diferencialmente em resposta a um elicitor isolado de fungo. A expressão do gene foi ativada por Pseudomonas syringae pv. glycinea não patogênica à $N$. tabacum e tardiamente, pelo patógeno de fumo, $P$. syringae pv. tabaci, sugerindo que o produto do gene, a proteína LRR, pode estar envolvida na resistência dessa planta contra doenças (Takemoto et al., 2000).

Foi verificado no presente trabalho que o ASM induziu em cafeeiro, genes envolvidos no metabolismo de lipídeos (Tabela 9). Trabalhos recentes apontam moléculas lipídicas como mensageiras da SAR, conforme já relatado na revisão de literatura (Maldonado et al., 2002 e Kumar \& Klessig, 2003). Foi constatado, também, que sinais derivados de ácidos graxos modulam a comunicação entre as diferentes vias sinalizadoras de defesa (Nandi et al., 2003). Moléculas lipídicas podem, ainda, estar envolvidas na sinalização de respostas de defesa. O clone de cDNA, MN-HSS4-G07, apresentou maior similaridade com gene codificador da enzima acil-CoA sintetase, isolado de uma biblioteca de cDNA produzida a partir de tecidos foliares de pimenta tratados com ácido salicílico (Lee et al., 2001). A enzima acil-CoA sintetase está 
envolvida no transporte e metabolismo de lipídeos, como, por exemplo, na esterificação de ácidos graxos e também, na biossíntese, transporte e catabolismo de metabólitos secundários. Lee et al. (2001) observaram um rápido acúmulo de mRNAs do gene nos tecidos foliares das plantas em resposta ao tratamento com ácido salicílico ou à inoculação com $X$. campestris pv. vesicatoria. Os autores verificaram que o gene foi regulado por um promotor quase idêntico àqueles de genes da via biossintética de fenilpropanóides e concluíram, também, que a proteína acil-CoA sintetase, localizada na membrana plasmática, apresenta um papel na sinalização de respostas de defesa. A serina C-palmitoiltransferase, catalisa a primeira etapa na biossíntese de esfingolipídeos. Alguns esfingolipídeos são potentes moléculas mensageiras secundárias, que podem estar envolvidas na mobilização de íons cálcio ou também, como a ceramida, podem sinalizar a morte celular programada através da ativação de quinases. O clone de cDNA isolado de cafeeiro, após tratamento com o indutor de resistência ASM, apresentou maior similaridade com gene de batata codificador de serina C-palmitoiltransferase. $\mathrm{O}$ clone de cDNA codificador dessa proteína foi isolado de plantas de batata, também, por HSS, tendo sido verificado um aumento da expressão do gene durante a resposta de hipersensibilidade ativada em um cultivar resistente, após inoculação com o patógeno $P$. infestans (Birch et al., 1999). Como a serina C-palmitoiltransferase é uma enzima chave na biossíntese de esfingolipídeos, o isolamento de gene codificador dessa proteína em cafeeiro indica que pode ter ocorrido a síntese desses lipídeos nas plantas tratadas com o indutor de resistência. Em cafeeiro foram isolados, também, clones de cDNA similares a gene codificador de lipase isolado de A. thaliana (Tabela 9). Jakab et al. (2003) identificaram, por seleção diferencial, um gene codificador de lipase em plantas de Arabidopsis pré-tratadas com o indutor de resistência BABA. A expressão desse gene foi ativada pela aplicação de BABA, ácido salicílico, etileno e vários patógenos, sendo dependente de ácido salicílico e etileno. Foram identificados outros genes codificadores de lipases em A. thaliana, que apresentaram um padrão de expressão característico de genes codificadores de PR-proteínas. A sua expressão foi regulada e induzida por moléculas sinalizadoras de vias de defesa, tais como ácido salicílico, etileno e ácido jasmônico (Jakab et al., 2003). 
A degradação controlada de proteínas nas células vegetais é mediada pelo sistema ubiquitina/proteassomo e ubiquitina ligases. O proteassomo $26 \mathrm{~S}$ é um complexo multicatalítico de proteinases encontrado no núcleo ou citoplasma celular, sendo constituído por uma subunidade catalítica, denominada partícula $20 \mathrm{~S}$, que realiza a proteólise e a uma unidade reguladora, a partícula 19S, que reconhece a proteína alvo selecionada para a degradação. A proteína selecionada para degradação na célula vegetal é ligada à ubiquitina por meio da ação de ubiquitina ligases. A proteína marcada com ubiquitina é então reconhecida e degradada no proteassomo. A proteólise dependente de ubiquitina/proteassomo é necessária não apenas para a degradação de proteínas mal formadas ou danificadas e de proteínas funcionais que não são mais necessárias para a célula, mas é requerida, também, em outros processos, como por exemplo, na morte celular e na regulação da expressão gênica através do controle de fatores de transcrição específicos (Ingvardsen \& Veierskov, 2001). Em plantas, foi demonstrado que o proteassomo está envolvido na progressão (regulação) do ciclo celular, na senescência, nos primeiros estádios do desenvolvimento de plântulas e em respostas de defesa (Becker et al., 2000). Em cafeeiro, foram detectados genes que apresentaram similaridade com ubiquitina proteína ligase do tipo "Ring finger" e poliubiquitina, induzidos após o tratamento com o ASM, indicando que a proteólise pode ter sido ativada na resistência induzida no cultivar suscetível Mundo Novo (Tabela 10). A ubiquitina foi induzida, também, em cultura de células de soja em suspensão quando tratadas com elicitor proveniente de fungo ou $\mathrm{H}_{2} \mathrm{O}_{2}$ (Levine et al., 1994). Estudos mais recentes evidenciaram que o complexo proteassomo/ubiquitina pode desempenhar um papel importante na indução de respostas de defesa e na expressão da SAR em plantas. Genes envolvidos na degradação controlada de proteínas podem exercer um controle na expressão de genes relacionados à resistência, por exemplo, realizando a proteólise de inibidores da ativação de vias sinalizadoras de defesa. Becker et al. (2000) observaram que a síntese de mRNAs de quitinase induzida em plântulas de pepino por ácido salicílico e elicitor isolado das paredes celulares do fungo Phytophthora sojae foi suprimida por inibidores da atividade do proteassomo. Gene codificador de uma subunidade- $\beta$ do proteassomo $20 \mathrm{~S}$ foi ativado em $N$. tabacum pelo tratamento com ácido 
salicílico, $\mathrm{H}_{2} \mathrm{O}_{2}$ e com elicitinas, como a criptogeína, um elicitor protéico de respostas de defesa em plantas. A criptogeína induziu, também, em plantas de fumo, a resposta de hipersensibilidade e a SAR. Em plantas de fumo transformadas, incapazes de acumular ácido salicílico, não foi observada a indução do gene, após o tratamento com criptogeína ou ácido salicílico, sendo correlacionada com a perda simultânea da capacidade de expressar a SAR (Etienne et al., 2000). Foi sugerido, posteriormente, que a ativação de vários genes codificadores de diferentes subunidades do proteassomo $20 \mathrm{~S}$ poderia induzir uma proteólise específica envolvida na resposta de hipersensibilidade e na SAR monitorada por criptogeína em plantas de fumo (Dahan et al., 2001).

Além dos genes relacionados à resistência de plantas contra doenças, foi observada em cafeeiro Mundo Novo, a expressão de genes não implicados previamente em respostas de defesa (Tabela 11). Um total de $30 \%$ dos genes ativados em cafeeiro pelo tratamento com o indutor ASM apresentou função relacionada, à manutenção celular e desenvolvimento vegetal (Figura 12 e Tabela 11). A indução de alguns dos genes identificados em cafeeiro, como aqueles codificadores de proteína de ligação da clorofila $\mathrm{a} / \mathrm{b}$ (três clones), de transportador de hexose e de celulose sintase-2 (CesA-2) foi, também, observada em A. thaliana, após inoculação com A. brassicicola ou pelos tratamentos com ácido salicílico ou metil jasmonato (Schenk et al., 2000). A expressão de genes codificadores de rubisco activase, de um fator de ribosilação do ADP, de UDP glucose 4-epimerase e de glicosil transferase observada no cafeeiro tratado com indutor de resistência, foi verificada em plântulas de arroz, após inoculação com $P$. grisea ou pelos tratamentos com ASM ou ácido jasmônico (Xiong et al., 2001). Os resultados obtidos no presente trabalho sugerem a existência de uma comunicação entre vias de defesa e outras vias sinalizadoras, como havia sido observado por Schenk et al. (2000), quando detectaram $35 \%$ de genes ativados em Arabidopsis, envolvidos na manutenção celular e desenvolvimento vegetal. A complexidade de vias sinalizadoras na célula vegetal tem sido evidenciada pela ocorrência de comunicação ou interferência mútua, como por exemplo, entre as vias de defesa dependentes de ácido salicílico, ácido jasmônico e etileno, as quais podem afetar-se mutuamente, de forma positiva ou negativa (Genoud \& Métraux, 1999; Pieterse et al. 2001). Foi verificado, também, que a 
transdução de sinal em vias reguladas pela luz e nas vias sinalizadoras de genes relacionados à patogênese podem estar conectadas. A indução de resistência em Arabidopsis contra $P$. syringae e o acúmulo da proteína PR-1 mostrou uma forte dependência da luz. Plantas mutantes apresentando deficiência em receptores de luz (fitocromos) foram fortemente bloqueadas na expressão de resistência e indução de PR-1 mediada por ácido salicílico. Foi constatado que o efeito observado não foi ocasionado pela falta de fonte de carbono fotossintética, mas sim devido a um aumento da sensibilidade do tecido vegetal ao ácido salicílico endógeno, pela ação da luz (Genoud \& Métraux, 1999 e Métraux, 2001).

\subsubsection{Genes isolados de cafeeiro Híbrido de Timor inoculado com o patógeno $H$. vastatrix}

A técnica de hibridização subtrativa por supressão (HSS) permitiu isolar genes implicados no estresse oxidativo, na resposta de hipersensibilidade ou na morte celular programada induzidos em cafeeiro resistente Híbrido de Timor, 72 h após a inoculação com o patógeno $H$. vastatrix (Tabela 12). Similarmente ao observado em Mundo Novo foram detectados clones codificadores das enzimas antioxidantes, como a ascorbato peroxidase e catalase. Entretanto, ao contrário do observado no cultivar Mundo Novo, a expressão dos clones de cDNA que apresentaram maior similaridade com genes de catalase foi também detectada nas plantas não inoculadas com o patógeno, sugerindo que essa enzima não é induzida especificamente durante a resposta resistência (Figura 11 e Tabela 12). O patógeno induziu, também, em Híbrido de Timor, outros genes envolvidos nos mecanismos de proteção da célula vegetal, os quais apresentaram similaridade com as enzimas glutationa peroxidase e glutationa reductase. A glutationa peroxidase utiliza como substrato a glutationa para catalisar a redução de peróxido de hidrogênio ou peróxidos de lipídeos e hidroperóxidos orgânicos, minimizando os efeitos tóxicos desses compostos, produzidos durante o estresse oxidativo. A glutationa reductase, por sua vez, fornece substrato livre (glutationa reduzida) para a ação da glutationa peroxidase ou da GST. Em Híbrido de Timor foi observada, também, a 
indução de gene, similar à anidrase carbônica isolada de $N$. tabacum, envolvida na proteção contra danos oxidativos (Tabela 12). A anidrase carbônica isolada de cloroplasto de plantas de fumo (SABP3) possui capacidade de se ligar ao ácido salicílico e exibe atividade antioxidante. A co-expressão em folhas de Nicotiana benthamiana do gene de resistência de tomate, Pto, e do gene correspondente de avirulência, avrPto, de $P$. syringae, desencadeia a resposta de hipersensibilidade. O silenciamento da expressão de gene codificador de anidrase carbônica em folhas de $N$. benthamiana suprimiu a resposta de hipersensibilidade mediada por Pto:avrPto, ativada na resistência contra doenças (Slaymaker et al., 2002). A indução de gene similar à anidrase carbônica no cultivar resistente de cafeeiro, após a inoculação com o patógeno, sugere que esse gene poderia ter um papel na mediação da resposta de hipersensibilidade na interação incompatível Híbrido de Timor-H.vastatrix. A expressão em cafeeiro de genes codificadores de enzimas antioxidantes sugere que houve a produção de ROS durante a resposta de resistência ativada em Híbrido de Timor após o contacto com $H$. vastatrix. Foi detectado em cafeeiro resistente, um clone de cDNA que apresentou similaridade altamente significativa com gene de Oryza sativa, codificador de uma proteína pertencente à uma família de genes de defesa denominada HIR (" $\underline{h y p e r s e n s i t i v e ~ i n d u c e d ~}$ reaction" - reação de hipersensibilidade induzida). Os membros dessa família estão associados com reações de hipersensibilidade envolvendo a morte celular e resistência contra fitopatógenos (Nadimpalli et al., 2000). As proteínas HIR fazem parte de uma superfamília denominada PID (“proliferation, ֵon, and death”) formada, também, por proibitinas e estomatinas, envolvidas na proliferação e controle do ciclo celular e na regulação do canal de íons, respectivamente. A indução desse gene foi também observada em plantas de tomate expressando constitutivamente o gene de resistência Pto (35S::Pto) (Xiao et al., 2001). Foi verificado, também, que um gene da família HIR de $N$. tabacum induziu nessa planta, a resposta de hipersensibilidade e a expressão de gene PR-2 codificador de $\beta$-1,3-glucanase (Karrer et al., 1998). A detecção de gene da família HIR em cafeeiro, além de um clone de cDNA similar à gene de cisteína protease, que pode estar envolvida na mediação da morte celular programada (Solomon et al., 1999), sugere que ocorreu ativação da resposta de hipersensibilidade no cafeeiro resistente 
Híbrido de Timor, $72 \mathrm{~h}$ após a inoculação com o patógeno (Tabela 12). A ativação dessa resposta tem sido normalmente observada em outras interações incompatíveis, embora a expressão da resistência nem sempre esteja vinculada à resposta de hipersensibilidade. Os resultados obtidos no presente trabalho corroboram as observações feitas por outros autores, através de estudos citológicos realizados com diferentes genótipos de cafeeiro apresentando resistência completa a $H$. vastatrix. Uma das primeiras respostas de resistência observada, iniciada 48 h após a inoculação das plantas, consistiu na reação de hipersensibilidade, evidenciada pela morte rápida das células do hospedeiro no sítio de infecção, acompanhada pelo encapsulamento dos haustórios do patógeno através do depósito de calose e celulose (Guerra-Guimarães et al., 2001 e Silva et al., 2002).

Foram induzidos em Híbrido de Timor após a inoculação com o patógeno, alguns genes que apresentaram similaridade com aqueles codificadores de proteínas antimicrobianas, como a aspártico proteinase, inibidores de cisteína proteinase tipo cistatina e $\beta$-1,3-glucanase, já descritos para o cultivar Mundo Novo (Tabela 13). O clone de cDNA isolado de cafeeiro Híbrido de Timor apresentou similaridade com a aspártico protease, isolada de tomateiro por Schaller \& Ryan (1996), mencionada anteriormente, que pode estar associada à defesa contra insetos herbívoros. Além destes, foi isolado um clone de cDNA que apresentou similaridade com gene codificador de proteína inibidora de pectina metilesterases e invertases (PMEI), implicada na regulação do desenvolvimento de frutos, metabolismo de carboidratos, extensão da parede celular e inibição de patógenos microbianos. Na defesa de plantas contra fitopatógenos as proteínas PMEI estão envolvidas na proteção contra enzimas secretadas por microrganismos patogênicos, como as pectinases, que degradam os polissacarídeos pécticos da parede celular do hospedeiro. A extensão da degradação da parede celular vegetal é controlada pela presença de proteínas da planta que inibem a ação hidrolítica dessas enzimas microbianas (Esquerré-Tugayé et al., 2000). Em cafeeiro Híbrido de Timor, a PMEI poderia ter sido ativada para a proteção das células vegetais contra a ação de enzimas pectinolíticas secretadas por $H$. vastatrix na patogênese.

O fato de terem sido detectados dois clones de cDNA codificadores da enzima CAD sugere que pode ter ocorrido a síntese de lignina durante a resposta de defesa de 
Híbrido de Timor contra H. vastatrix (Tabela 14 e Figura 11). Esta suposição é reforçada por estudos realizados por Silva et al. (2002), que observaram histologicamente a lignificação das paredes celulares dos tecidos foliares de cultivares resistentes de $C$. arabica e Coffea congensis, cinco dias após a inoculação das plantas com uma raça avirulenta de $H$. vastatrix.

A indução, em Híbrido de Timor, de genes codificadores de isoflavona redutase, implicada na síntese de fitoalexinas isoflavonóides e das enzimas (S)-Nmetilcoclaurina 3'-hidroxilase e reticulina oxidase, envolvidas na mesma via metabólica para a biossíntese de alcalóides, sugere que esses compostos antimicrobianos do metabolismo secundário podem ter sido sintetizados em cafeeiro durante a resposta de resistência ativada contra $H$. vastatrix (Tabela 14 e Figura 11). O possível acúmulo de fitoalexinas isoflavonóides e de alcalóides antimicrobianos nos tecidos foliares de cafeeiro poderia contribuir para a inibição do desenvolvimento do patógeno em Híbrido de Timor. De fato, Rodrigues Jr. et al. (1975b) sugeriram a formação de fitoalexinas nas interações incompatíveis entre cafeeiro-ferrugem, embora não se tenha procedido ao seu isolamento. A isoflavona redutase, que atua na via metabólica de isoflavonas, catalisa uma etapa específica para a biossíntese de fitoalexinas, como a medicarpina e pisatina, isoladas de alfafa e de ervilha, respectivamente. A transcrição de gene codificador de isoflavona redutase foi altamente induzida em cultura de células de alfafa em resposta ao tratamento com elicitores, que são substâncias capazes de ativar a síntese de fitoalexinas em plantas. A indução do gene foi correlacionada com o aumento de atividade enzimática da isoflavona redutase, com o acúmulo de medicarpina e com a indução de outras enzimas específicas dessa via metabólica (Paiva et al., 1991). Em plântulas de ervilha tratadas com cloreto de cobre foi observada, também, uma intensa transcrição de gene codificador de isoflavona redutase, consistente com a detecção da atividade enzimática dessa proteína e com o acúmulo de pisatina (Paiva et al., 1994). A enzima (S)-N-metilcoclaurina 3'-hidroxilase catalisa a penúltima etapa para a biossíntese do alcalóide intermediário central (S)-reticulina. A (S)-reticulina pode dar origem a uma ampla variedade de alcalóides dependendo da ação de diferentes enzimas, como, por exemplo, da reticulina oxidase (enzima da ponte de berberina), resultando na formação 
de berberina, um alcalóide antimicrobiano. O clone de cDNA isolado de Híbrido de Timor apresentou similaridade altamente significativa com gene de (S)-Nmetilcoclaurina 3'-hidroxilase isolado de cultura de células de papoula tratadas com metil jasmonato (Pauli \& Kutchan, 1998). A enzima da ponte de berberina é essencial para a biossíntese de um grupo de alcalóides, as benzofenantridinas, que apresentam atividade antimicrobiana e acumulam-se em algumas espécies vegetais em resposta ao ataque por fitopatógenos, apresentando uma ação similar às fitoalexinas. Foi observada a expressão de gene codificador da enzima da ponte de berberina e a produção concomitante de alcalóides, em cultura de células de papoula tratadas com uma preparação de parede celular de S. cerevisiae (Dittrich \& Kutchan, 1991).

Foram detectados em cafeeiro Híbrido de Timor após inoculação com o patógeno, dez clones de cDNA que apresentaram similaridade com genes codificadores de proteínas transportadoras $\mathrm{ABC}$ isolados de A. thaliana, N. tabacum, O. sativa e da planta aquática Spirodela polyrrhiza (Tabela 14). Os transportadores ABC de ligação ao ATP compreendem uma superfamília de proteínas localizadas na membrana que exportam uma ampla variedade de compostos citotóxicos, utilizando a energia de hidrólise do ATP para o transporte ativo de diferentes substratos. A maioria dos transportadores $\mathrm{ABC}$ caracterizados em plantas estão localizados na membrana de vacúolos e estão envolvidos na absorção intracelular de compostos tóxicos à célula vegetal. Quatro clones de cDNA isolados de Híbrido de Timor, apresentaram similaridade com gene codificador de transportador ABC tipo PDR (NtPDR1) isolado de cultura de células de $N$. tabacum, após indução com elicitina, uma proteína proveniente do fungo $P$. infestans, que induz a resposta de hipersensibilidade em fumo (Sasabe et al., 2002). A expressão do gene NtPDR1 foi rapidamente e intensamente induzida pela elicitina, e por uma proteína indutora de resposta de hipersensibilidade, isolada da bactéria $P$. syringae pv. tomato. O gene NtPDR1 foi ativado, também, por extrato de levedura ou por metil jasmonato. Por outro lado, foi observado por Jasiński et al. (2001), que uma proteína transportadora $\mathrm{ABC}$ localizada na membrana plasmática $(\mathrm{NpABC} 1)$ isolada de Nicotiana plumbaginifolia está envolvida na secreção de diterpenos antifúngicos, compostos do metabolismo secundário, que desempenham um papel na 
defesa de plantas contra fitopatógenos. Foi verificado, ainda, que a expressão de um transportador $\mathrm{ABC}$ em plantas de tomate (Pti3) está envolvida na indução da resposta de hipersensibilidade, mediada pelo gene Pto que confere resistência contra $P$. syringae pv. tomato (Sessa et al., 2000). Esses trabalhos evidenciam o envolvimento de transportadores $\mathrm{ABC}$ nos mecanismos de defesa de plantas contra fitopatógenos. Os resultados obtidos no presente trabalho indicam que genes codificadores de proteínas transportadoras $\mathrm{ABC}$ foram ativados na interação incompatível Híbrido de Timor- $H$. vastatrix (Tabela 14 e Figura 11). Essas proteínas poderiam contribuir para a destoxificação celular transportando compostos fenólicos tóxicos à célula vegetal acumulados durante a resposta de defesa, por exemplo, na expressão da reação de hipersensibilidade. Poderiam, ainda, estar envolvidas na secreção, para os espaços intercelulares, de compostos antifúngicos do metabolismo secundário, restringindo o desenvolvimento do patógeno. Entretanto, estudos posteriores devem ser conduzidos para elucidar o envolvimento dessas proteínas na resistência de cafeeiro contra $H$. vastatrix.

A enzima fosfolipase hidrolisa a membrana celular vegetal produzindo lisofosfolipídeos e ácidos graxos livres, como o linoleico e o linolênico. Esses compostos são utilizados pela enzima lipoxigenase (LOX), que dará origem aos hidroperóxidos de lipídeos, como por exemplo, o ácido hidroperoxilinolênico, substrato utilizado pela aleno óxido sintase (AOS) para a síntese de ácido jasmônico. As fosfolipases A de plantas podem mediar a ação de elicitores de respostas de defesa provenientes de fungos. Várias enzimas, tais como a $\beta$-1,3-glucanase, são induzidas como resultado da ativação de fosfolipases $A_{2}$ (Trewavas, 2000). Por outro lado, os hidroperóxidos de lipídeos formados pela ação da LOX, são tóxicos a fitopatógenos e podem, também, causar a necrose da célula vegetal (Rustérucci et al., 1999). Foi observado que a resposta de hipersensibilidade induzida nos tecidos foliares de plantas de fumo pela proteína criptogeína purificada de $P$. cryptogea, depende da produção de peróxidos de lipídeos pela ação da enzima LOX. Foi verificado, também, o envolvimento da atividade de uma lipase para fornecer os substratos para a LOX, através da hidrólise da membrana celular vegetal durante a resposta de hipersensibilidade 
(Rustérucci et al., 1999). Foram isolados em Híbrido de Timor clones de cDNA que apresentaram similaridade com genes isolados de plantas, que codificaram as enzimas fosfolipase e LOX (Tabela 15). A indução desses genes em cafeeiro em resposta à presença do patógeno, sugere que alguns dos processos acima mencionados podem ter sido ativados em Híbrido de Timor durante a resposta de resistência.

A ACC oxidase (1-aminociclopropano-1-carboxilato oxidase), conhecida previamente como a enzima formadora de etileno, catalisa a última etapa na biossíntese de etileno, a partir de ACC (ácido 1-aminociclopropano-1-carboxílico). O precursor imediato do etileno, ACC, é produzido a partir do ciclo de Yang. O fato de ter sido detectado um clone de cDNA em Híbrido de Timor similar a gene codificador de ACC oxidase isolado de plantas de tomate, sugere que essa via metabólica levando à síntese desse regulador vegetal, pode ter sido ativada no cultivar resistente em resposta a $H$. vastatrix (Tabela 15, Figura 11). Muitos genes codificadores de PR-proteínas que são induzidos nas interações planta-patógeno são regulados pelo etileno. Foi observado também, que a expressão de alguns destes genes em determinadas plantas é independente de ácido salicílico, mas requer a ativação da via sinalizadora regulada pelo etileno. As PR-proteínas induzidas pelo etileno são normalmente básicas como, por exemplo, as defensinas, $\beta$-1,3-glucanases básicas e osmotinas. Em plantas de tomate portadoras do gene de resistência Pto, o etileno induziu rapidamente a expressão de gene codificador de um fator de transcrição (Pti4), seguida pela indução de genes de uma quitinase básica, de uma $\beta$-1,3-glucanase básica e de osmotina. A proteína Pti4 se liga especificamente a uma região do promotor de muitos genes codificadores de PRproteínas, sendo que essa ligação é intensificada, quando o fator de transcrição é fosforilado ( $\mathrm{Gu}$ et al., 2000). No presente trabalho, foi observada a indução de gene codificador de uma $\beta$-1,3-glucanase básica no cafeeiro resistente Híbrido de Timor inoculado com o patógeno (Tabelas 13 e 20). A indução desse gene pode ter sido regulada pelo etileno durante a resposta de resistência. Como já observado no cultivar Mundo Novo, foi detectado em Híbrido de Timor um clone de cDNA que apresentou similaridade com gene codificador de SAM sintetase isolado de Catharanthus roseus, enzima do ciclo de Yang, que pode levar à síntese de etileno (Tabelas 7 e 15). 
A expressão de resistência em uma interação incompatível planta-patógeno depende da ativação de mecanismos eficientes de reconhecimento, que envolvem a interação entre produto de gene de resistência do hospedeiro com o produto de gene correspondente de avirulência do patógeno e a subseqüente ativação de mecanismos de transdução de sinais. Os mecanismos de sinalização na célula vegetal resultam na expressão de genes e síntese de compostos de defesa que vão bloquear o desenvolvimento do patógeno nos tecidos vegetais. $\mathrm{Na}$ interação entre um cultivar resistente de cafeeiro e uma raça avirulenta do patógeno $H$. vastatrix, a expressão de incompatibilidade ocorre na fase de formação dos primeiros haustórios na célula vegetal, entre 48 e 72 h após a inoculação (Martins \& Moraes, 1996 e Silva et al., 2002). Vários genes de resistência contra doenças já foram isolados de diferentes plantas (genes-R) e codificam serina-treonina quinases ou proteínas com repetições ricas em leucina (LRR), com sítio de ligação à nucleotídeo (NBS), com zíper de leucina (LZ) ou com domínio de resistência Toll/interleukina-1 (TIR). Por exemplo, o gene Xa21, que confere resistência em arroz contra Xanthomonas oryzae pv. oryzae, codifica uma proteína de membrana com domínio extracelular LRR e outro intracelular de quinase. Os genes de tomate $C f-2$, $C f-4, C f-5$ e $C f-9$ que conferem resistência contra o fungo $C$. fulvum codificam, também, uma proteína de membrana que apresenta, entretanto, apenas um domínio extracelular LRR. O gene Pto de tomate que confere resistência contra $P$. syringae pv. tomato codifica uma serina-treonina quinase intracelular, enquanto que o gene de Arabidopsis, RPS2, que confere resistência ao mesmo patógeno, codifica, também, uma proteína localizada no citopasma, mas que apresenta domínio LZ-NBS-LRR. O gene L6 do linho, que confere resistência ao agente causal da ferrugem nessa planta, o fungo Melampsora lini, especificamente às raças fisiológicas portadoras do gene de avirulência $A L 6$, codifica uma proteína intracelular TIR-NBS-LRR (Hammond-Kosack \& Jones, 2000). Alguns genes- $\mathrm{R}$ podem ser induzidos em resposta a infecção por patógenos. A expressão do gene $X a 1$ que confere resistência em arroz contra $X$. oryzae pv. oryzae e codifica uma proteína NBS-LRR localizada no citoplasma, foi induzida pela inoculação com essa bactéria (Yoshimura et al., 1998). Em Híbrido de Timor foi possível isolar cinco clones de cDNA, que apresentaram similaridade com genes isolados de outras plantas 
codificadores de proteínas de resistência, por exemplo, do tipo LRR de arroz, NBS-LRR de Solanum acaule ou com domínio TIR-NBS-LRR de linho (Tabela 16). Esses genes isolados de Híbrido de Timor foram ativados em resposta à presença do patógeno e podem representar genes-R, envolvidos nos mecanismos específicos de reconhecimento, que conferem resistência em cafeeiro às raças fisiológicas de $H$. vastatrix, portadoras de genes correspondentes de avirulência (Tabela 16 e Figura 11). Uma outra possibilidade é que os clones de cDNA isolados de Híbrido de Timor, representem análogos de genes de resistência (RGA) que podem auxiliar na modulação de respostas de defesa. Nem todos os produtos de genes de resistência contêm os domínios funcionais descritos. O gene mlo de cevada não é um gene-R raça-específico, pois confere ampla resistência a todas as raças conhecidas de B. graminis f.sp. hordei. A proteína MLO está localizada na membrana plasmática e não possui nenhum dos motivos estruturais presentes nas proteínas-R, que conferem resistência raça-específica (Piffanelli et al., 2002). Uma mutação em gene-R de cevada raça-específico não interfere na resposta de resistência mediada por mlo e o inverso também é verdadeiro, indicando vias sinalizadoras distintas. Em Híbrido de Timor foi isolado um clone de cDNA que apresentou similaridade com gene codificador da proteína MLO, ativado pela inoculação com $H$. vastatrix. (Tabela 16 e Figura 11). Pode-se aventar a possibilidade, de que essa proteína no cafeeiro esteja envolvida em mecanismos de resistência inespecíficos, conferindo ampla resistência a outros microrganismos não patogênicos ao cafeeiro, embora esses aspectos necessitem ser elucidados. Proteínas MLO têm sido identificadas em outras plantas, mas com exceção da MLO de cevada, os mecanismos bioquímicos e função biológica dessas proteínas são desconhecidos (Piffanelli et al., 2002).

Foi possível isolar de Híbrido de Timor por HSS, outros clones de cDNA representando genes que foram induzidos pelo patógeno e estão implicados em processos de sinalização, como aqueles codificadores de um fator de transcrição da família bZIP, de proteínas de ligação à calmodulina ou ao GTP, quinases, quinases tipo receptoras, quinases específicas, como uma quinase tipo CIPK de interação com calcineurina B conforme descrito para o cultivar Mundo Novo, além de uma quinase CDPK e de uma MAP-quinase (Tabela 16). 
Conforme já mencionado, a calmodulina desempenha um papel importante na percepção e sinalização para a célula vegetal de modificações na concentração de íons cálcio. Um clone de cDNA isolado de Híbrido de Timor apresentou maior similaridade com gene codificador de proteína de ligação à calmodulina isolado de plantas de feijão, o qual foi ativado em interações incompatíveis planta-patógeno e após o tratamento com indutores de respostas de defesa (Ali et al., 2003). As quinases CDPK apresentam um domínio de calmodulina próximo à região C-terminal, capaz de se ligar aos íons cálcio e um domínio catalítico de quinase na região $\mathrm{N}$-terminal da mesma molécula. Na presença de íons $\mathrm{Ca}^{2+}$ o sítio de quinase é exposto e sua atividade catalítica é iniciada. Em plantas de fumo foram isolados dois clones de cDNA codificadores de proteínas quinases dependentes de cálcio, do tipo CDPKs. Foi observado um aumento na transcrição dos genes de CDPK nas plantas em resposta a estresse ou ao tratamento com um elicitor raça-específico. Através do silenciamento dos genes CDPKs em plantas de fumo, foi possível constatar que as proteínas quinases codificadas por esses genes são requeridas para a ativação de respostas de defesa, especificamente, a resposta de hipersensibilidade induzida em interações do tipo gene-a-gene (Romeis et al., 2001). Em Híbrido de Timor foi isolado um clone de cDNA similar a uma proteína CDPK isolada de plantas de fumo, correspondendo a gene induzido por $H$. vastatrix (Tabela 16 e Figura 11). A indução desse gene na planta, após o contato com o patógeno, poderia estar relacionada à ativação da resposta de hipersensibilidade em cafeeiro. Como os processos iniciais de sinalização que ativam a resposta de hipersensibilidade em plantas incluem mudanças nos fluxos de íons e ativação de proteínas quinases, a inativação de proteínas CDPKs poderia comprometer a cascata sinalizadora dessa resposta em uma interação gene-agene.

Foi isolado de cafeeiro resistente um clone de cDNA, que apresentou alta similaridade com gene isolado de plantas de fumo codificador de uma MAP-quinase denominada WIPK, induzida por patógenos ou em resposta a ferimentos (Tabela 16). As MAP-quinases são responsáveis pela regulação direta de fatores de transcrição. Um diterpeno isolado de folhas de fumo, após a inoculação com o TMV, foi capaz de ativar a MAP-quinase WIPK e a síntese das PR-proteínas, PR-1 e PR-2 ( $\beta$-1,3-glucanase) 
básicas, além de um inibidor de proteinase e da enzima ACC oxidase. Entretanto, esse composto não induziu o acúmulo de acido salić́lico ou de PR-proteínas ácidas em plantas de fumo. Além desses aspectos, em plantas de fumo portadoras do gene $N$ de resistência codificador de uma proteína TIR-NBS-LRR, foi detectado um aumento rápido na concentração do diterpeno durante a resposta de hipersensibilidade, levando a crer que esse composto age como um sinal endógeno para mediar as respostas de defesa em plantas de fumo contra TMV e ferimento (Seo et al., 2003). De forma similar, foi observado no presente trabalho, em Híbrido de Timor de Timor após inoculação com o patógeno, a indução de genes codificadores de uma $\beta$-1,3-glucanase básica, de inibidores de proteinase, de ACC oxidase, de MAP quinase similar a WIPK e de proteínas transportadoras $\mathrm{ABC}$, que podem estar envolvidas na secreção de diterpenos (Tabelas 13, 14, 15, 16 e 20 e Figura 11). Por outro lado, não foram detectadas PRproteínas ácidas, similarmente ao observado em plantas de fumo. Seria interessante estudar posteriormente como esses mecanismos são ativados em cafeeiro e elucidar sua relação com a ativação da resposta de hipersensibilidade e implicação na resistência em cafeeiro contra fitopatógenos. Em plantas de fumo, um fator de transcrição da família bZIP está envolvido em respostas mediadas por auxina e no estabelecimento de respostas de defesa contra fitopatógenos. Foi observado que uma proteína com repetições de anquirina ANK1, interage especificamente com uma região presente nesse fator de transcrição. O gene codificador de ANK1 se expressa constitutivamente, mas sua transcrição é transitoriamente reprimida após inoculação com fitopatógenos. A anquirina parece regular a expressão do bZIP na sinalização mediada por auxina e nas respostas de defesa contra patógenos (Kuhlmann et al., 2003). Em cafeeiro Híbrido de Timor foi observada a ativação de um fator de transcrição da família bZIP, após a inoculação com o patógeno, não sendo observada, entretanto, a ativação de gene que apresentou similaridade com uma proteína com repetições de anquirina (Tabela 16 e Figura 11).

Foram detectadas em leguminosas, como soja e feijão, proteínas receptoras localizadas na membrana plasmática que apresentam capacidade de ligação à $\beta$-glucanas (Mithöfer et al., 2000 e Umemoto et al., 1997). Em soja, estudos demonstraram que 
essas proteínas ligam-se a $\beta$-glucanas liberadas das paredes celulares do fungo fitopatogênico Phytophthora megasperma, através da ação de glucanases da soja, ativando subseqüentemente respostas de defesa nas plantas, como a formação da fitolexina gliceolina (Umemoto et al., 1997). Através do isolamento de cDNAs codificadores dessas proteínas em feijão e soja, foi constatado que a ligação dos receptores de $\beta$-glucanas com oligossacarídeos provenientes de fungos fitopatogênicos, pode mediar a sinalização de respostas de defesa (Mithöfer et al., 2000 e Umemoto et al., 1997). No presente trabalho foi possível isolar de Híbrido de Timor, um clone de cDNA que apresentou similaridade altamente significativa com receptor de Brassica napus (Tabela 16) e com esses receptores isolados de soja e feijão. Além desse aspecto, a seqüência de aminoácidos deduzida a partir do cDNA isolado de cafeeiro apresentou os mesmos domínios encontrados para as seqüências de receptores isolados dessas plantas. Como as células mãe de haustórios e os haustórios de $H$. vastatrix apresentam $\beta$-glucanas nas paredes celulares (Guerra-Guimarães et al., 2001), poderia ser aventada a possibilidade do receptor de $\beta$-glucanas de cafeeiro reconhecer o patógeno, através da ligação com esses polissacarídeos, resultando na ativação de algumas respostas de defesa. Por outro lado, foi isolado de cafeeiro resistente, após inoculação com o patógeno, gene codificador de uma $\beta$-1,3-glucanase (Tabelas 13 e 20). Essa enzima poderia hidrolisar parcialmente $\beta$-glucanas presentes nas paredes celulares de hifas de $H$. vastatrix e liberar oligossacarídeos, que seriam, subseqüentemente, reconhecidos por esse receptor de elicitor $\beta$-glucana detectado em Híbrido de Timor. Entretanto, essas possibilidades precisam ser posteriormente investigadas.

Entre os clones de cDNA isolados de Híbrido de Timor envolvidos no metabolismo de lipídeos, encontram-se quatro clones que apresentaram similaridade com gene codificador de acil-CoA sintetase de C. annuum semelhante àquele isolado de Mundo Novo (Tabelas 9 e 17). Além destes, a indução em cafeeiro resistente de gene codificador de acil-CoA oxidase, enzima que catalisa a primeira etapa da $\beta$-oxidação de ácidos graxos e de omega-6 ácido graxo desaturase, indica que o metabolismo de lipídeos foi ativado na interação incompatível Híbrido de Timor-H.vastatrix (Tabela 17). 
A omega-6 ácido graxo desaturase ( $\omega 6$-desaturase) é membro de uma família de enzimas que desempenham um papel importante na regulação da concentração total de ácidos graxos insaturados na célula e está, especialmente, envolvida na síntese de lipídeos contendo ácidos graxos poliinsaturados. Estudos recentes efetuados com plantas mutantes de A. thaliana revelaram que o nível de insaturação dos ácidos graxos na célula vegetal, o qual é regulado pela ação dessas enzimas, afeta as vias sinalizadoras de respostas de defesa, inclusive aquelas ativadas por ácido salicílico ou ácido jasmônico. A mutação no gene de Arabidopsis que codifica uma $\omega 6$-desaturase suprime uma etapa que é comum para a ativação da morte celular, acúmulo de ácido salicílico e ativação de vias de defesa independentes da proteína reguladora NPR1 (Nandi et al., 2003). A indução de gene codificador de $\omega 6$-desaturase em Híbrido de Timor sugere que essas vias podem ter sido ativadas durante a resposta de resistência de cafeeiro contra $H$. vastatrix. Xiao et al. (2001), empregando, também, a HSS, isolaram de plantas de tomate expressando constitutivamente o gene de resistência Pto (35S::Pto), clones de cDNA codificadores de proteínas envolvidas no metabolismo de lipídeos, como a $\omega 6$ desaturase.

Foi observada em cafeeiro resistente Híbrido de Timor, a expressão de vários componentes envolvidos na degradação controlada de proteínas, como ubiquitinas, ubiquitina ligase, subunidade reguladora do proteassomo $26 \mathrm{~S}$ e subunidades- $\alpha$ e $\beta$ do proteassomo 20S, unidade catalítica responsável pela proteólise (Tabela 18). Esses resultados sugerem que ocorreu proteólise durante a expressão de resistência em cafeeiro, após a inoculação com o patógeno. A proteólise pode ser essencial para a expressão da resistência em algumas interações hospedeiro-patógeno. A associação da proteína reguladora SGT1 com ubiquitina ligase é necessária para a expressão da resistência contra doenças em plantas, mediada por proteínas tipo NBS-LRR (Peart et al., 2002). Foi observado que o silenciamento do gene codificador de SGT1 em $N$. benthamiana interferiu, não apenas na expressão de resistência raça-cultivar específica mediada por proteínas NBS-LRR e por outras proteínas de resistência, como também, em plantas não hospedeiras. A expressão de genes relacionados à proteólise foi, também, 
observada em outras interações incompatíveis, como em cultivar resistente de plantas de batata contra P. infestans (Birch et al., 1999) e em Arabidopsis contra A. brassicicola (Schenk et al., 2000).

Como foi observado no cultivar Mundo Novo após o tratamento com indutor de resistência, ocorreu, também, na interação incompatível Híbrido de Timor-H. vastatrix, a indução de genes apresentando funções relacionadas a diferentes vias metabólicas, além daquelas implicadas na resistência contra doenças (Tabela 19). Um total de $30 \%$ dos genes ativados em Híbrido de Timor apresentou função relacionada, à manutenção celular e desenvolvimento vegetal, como por exemplo, aqueles codificadores de transportador de açúcar (seis clones), de proteína de ligação da clorofila a/b (um clone), de rubisco activase (três clones), de proteínas de choque térmico (doze clones), de citocromo P450 (quatro clones), de ciclofilina (um clone) e de actina (um clone) (Figura 13 e Tabela 19). Os resultados indicam que ocorre a ativação de vias do metabolismo primário juntamente com a indução de vias sinalizadoras para a expressão de genes relacionados à defesa. A indução de vários genes de manutenção celular pode acompanhar as respostas de defesa para assegurar que concentrações adequadas de compostos precursores sejam mantidas na célula vegetal (Hammond-Kosack \& Jones, 1996). A indução de alguns dos genes mencionados foi também observada em outras interações incompatíveis, como por exemplo, em cultivar resistente de batata inoculado com P. infestans, sendo detectada por HSS (Birch et al., 1999). Genes envolvidos no metabolismo de açúcar, como transportadores de glucose, foram intensamente induzidos em Arabidopsis em resposta ao tratamento com ácido salicílico ou metil jasmonato (Schenk et al., 2000). A indução de genes para o transporte de açúcares, após a inoculação com patógenos e tratamento com elicitor de respostas de defesa foi relatada previamente (Truernit et al., 1996). 


\title{
5.2.3. Determinação por seleção diferencial da expressão de genes ativados em cafeeiro cv. Mundo Novo após tratamento com ASM e em Híbrido de
} Timor, após inoculação com $H$. vastatrix

\begin{abstract}
A técnica da seleção diferencial permitiu avaliar que cerca de $79 \%$ e $77 \%$ dos clones de cDNAs presentes, respectivamente, nas bibliotecas subtraídas de cafeeiro Mundo Novo e Híbrido de Timor, obtidas por HSS, correspondem a genes possivelmente induzidos nas condições estudadas. Birch et al. (1999) isolaram genes de um cultivar resistente de batata, induzidos nos primeiros estágios da resposta de hipersensibilidade à $P$. infestans, utilizando a técnica da HSS para gerar uma biblioteca de cDNA enriquecida de seqüências induzidas durante essa resposta. Para confirmar quais os clones individuais, presentes na biblioteca de cDNA subtraída, representavam genes expressos diferencialmente, utilizaram, também, a técnica da seleção diferencial e verificaram que 75\% dos clones correspondiam a genes ativados. Xiao et al. (2001), empregando, também a HSS, isolaram de plantas de tomate expressando constitutivamente o gene de resistência Pto (35S::Pto), genes associados a mecanismos de defesa. Para confirmar a expressão diferencial dos clones de cDNA da biblioteca subtraída realizaram a análise por "Reverse Northern" e observaram que $83 \%$ dos clones correspondiam a genes ativados nas folhas de tomate $35 \mathrm{~S}:$ :Pto.

A técnica de seleção diferencial utilizada no presente trabalho e recomendada para confirmar os clones de cDNA que são expressos diferencialmente em bibliotecas subtraídas obtidas após a HSS, permitiu avaliar os genes ativados em Mundo Novo pelo indutor de resistência e no Híbrido de Timor em resposta ao patógeno. Entretanto, é possível que cerca de 1 a $2 \%$ dos clones identificados por seleção diferencial com as sondas subtraídas não representem genes realmente ativados nas condições estudadas (PCR-Select Differential Screening Kit User Manual, 2001a). Posteriormente será utilizada uma outra técnica, por exemplo, o "Northern blot", para realizar um estudo mais detalhado da expressão e regulação temporal da transcrição de genes de interesse detectados nas bibliotecas subtraídas.
\end{abstract}




\subsubsection{Comparação de genes isolados por HSS induzidos em cafeeiro cv. Mundo Novo após tratamento com o indutor de resistência, com aqueles ativados em Híbrido de Timor em resposta à $H$. vastatrix}

Foi possível isolar por HSS, do cv. Mundo Novo com resistência induzida e da interação incompatível Híbrido de Timor - $H$. vastatrix, vários clones de cDNA que apresentaram similaridade com genes, isolados de outras plantas, codificadores de proteínas com funções similares. Entre estes, podem ser mencionados aqueles codificadores de cisteína proteinases envolvidas na resposta de hipersensibilidade ou genes de enzimas antioxidantes, como ascorbato peroxidase, glutationa-S-transferase ou glutationa peroxidase. Foram detectados, também, nas duas interações, genes antimicrobianos com funções similares, como a aspártico protease, cistatinas e $\beta$-1,3glucanase, gene envolvido na síntese de compostos do metabolismo secundário, como a CAD, gene envolvido na síntese de compostos com função sinalizadora de respostas de defesa, como a SAM-sintetase, genes de quinase tipo CIPK e serina/treonina quinases relacionadas à percepção e transdução de sinal, além de genes envolvidos no metabolismo de lipídeos, como a acil-CoA sintetase e na degradação controlada de proteínas, como poliubiquitina e ubiquitina proteína ligase. Esses resultados indicam que alguns compostos relacionados à defesa e associados a diferentes processos, como lignificação dos tecidos vegetais, produção de espécies reativas de oxigênio, resposta de hipersensibilidade e degradação controlada de proteínas, são ativados tanto na resistência induzida como na resistência vertical.

Entretanto, a comparação dos genes isolados por HSS de cafeeiro suscetível cv. Mundo Novo após tratamento com o indutor de resistência e de cafeeiro resistente Híbrido de Timor em resposta à $H$. vastatrix revelou algumas diferenças, que podem estar relacionadas com mecanismos distintos de resistência ativados nessas interações. Além de terem sido detectados genes nas duas interações, apresentando funções distintas, o número de genes associado a alguns dos processos relacionados à defesa não foi similar. Eventos de reconhecimento e vias de defesa distintas parecem estar 
envolvidas na expressão de resistência em Híbrido de Timor-H. vastatrix e no Mundo Novo tratado com ASM.

Além de ter sido detectado um número maior de genes implicados em mecanismos de defesa na interação incompatível (22\%), do que no Mundo Novo com resistência induzida $(16 \%)$, foi possível observar que a resistência ativada no cafeeiro resistente está mais associada com a expressão de genes envolvidos nos mecanismos de percepção e transdução de sinal (44\%) e síntese e transporte de compostos do metabolismo secundário (23\%), do que a resistência induzida no cultivar suscetível, tendo sido detectados no Mundo Novo, para os mesmos processos, 30\% e 12\% do total de genes ativados, respectivamente (Figuras 12, 13, 14 e 15). Entretanto, a resistência induzida em cafeeiro Mundo Novo está especialmente relacionada com a expressão de genes codificadores de proteínas antimicrobianas (22\%), quando comparada com a resistência vertical observada no Híbrido de Timor (6\%) (Figuras 14 e 15). Esses resultados indicam que vias sinalizadoras distintas foram ativadas nas duas interações.

$\mathrm{Na}$ resistência induzida, após a ativação de mecanismos de defesa, se observa, freqüentemente, nas plantas previamente tratadas com indutores de resistência, uma diminuição e não a ausência de sintomas de doenças provocadas por fitopatógenos (Sticher et al., 1997). Tem sido observado que fitopatógenos podem se desenvolver parcialmente nos tecidos foliares de plantas que expressam a SAR (Friedrich et al., 1996). De fato, em cafeeiro tratado com o composto ASM e outros indutores de resistência como extrato de levedura, observa-se uma redução parcial dos sintomas da ferrugem (Tabela 1) (Martins \& Moraes, 1996). Na resistência induzida em um cultivar normalmente suscetível, como o cafeeiro Mundo Novo, apesar de mecanismos de sinalização serem ativados resultando na transcrição de genes de defesa, aspectos que foram observados no presente trabalho, o acúmulo de proteínas antimicrobianas pode se constituir em um mecanismo importante de resistência, degradando, por exemplo, as estruturas de infecção do patógeno, que está se desenvolvendo nos tecidos vegetais. Entretanto, em uma interação incompatível como cafeeiro Híbrido de Timor-H.vastatrix, o desenvolvimento do patógeno é totalmente bloqueado nos tecidos do hospedeiro em decorrência da ativação de mecanismos de defesa, não permitindo seu estabelecimento e 
a formação subseqüente de sintomas nas plantas. Nesse caso, os mecanismos específicos de reconhecimento mediados por proteínas de resistência de plantas como aquelas do tipo NBS-LRR, detectadas no presente trabalho, com a subseqüente ativação de mecanismos de percepção e transdução de sinais que levam, por exemplo, à ativação da resposta de hipersensibilidade e a síntese de compostos do metabolismo secundário que se acumulam rapidamente no sítio de infecção, podem ser essenciais para bloquear totalmente o desenvolvimento do patógeno, no ínicio da patôgenese. Por outro lado, o transporte de compostos do metabolismo secundário pode ter um papel importante na expressão da resistência raça-cultivar específica em cafeeiro, evidenciada pela detecção de vários clones de cDNA codificadores de proteínas transportadoras $\mathrm{ABC}$ detectados em Híbrido de Timor em resposta ao patógeno, em contraste com apenas um clone detectado em Mundo Novo com resistência induzida. O ácido jasmônico, molécula sinalizadora de respostas defesa, parece estar envolvido na expressão da resistência induzida em cafeeiro por ASM, tendo em vista o isolamento de genes indicando tanto a indução da via biossintética, como a ativação de via sinalizadora associada com esse regulador vegetal.

Os resultados obtidos no presente trabalho corroboram as observações feitas por Martins \& Moraes (1996), através de estudos histológicos comparativos conduzidos em cafeeiro suscetível com ou sem resistência induzida e em genótipo resistente, após a inoculação com $H$. vastatrix. Observou-se que a inibição do desenvolvimento de $H$. vastatrix no híbrido resistente Sarchimor foi iniciada após 48 h, sendo evidenciada, 72 h após a inoculação, pelo tamanho reduzido das colônias e diminuição de cerca de $50 \%$, no número de haustórios formados, em relação ao cultivar suscetível Mundo Novo. No cultivar suscetível tratado com extrato de levedura, a resistência foi expressa $72 \mathrm{~h}$ após a inoculação com o patógeno, observando-se na planta induzida o desaparecimento das estruturas de infecção do fungo. Os autores concluíram que a expressão de resistência em Sarchimor ocorre mais rapidamente do que em Mundo Novo com resistência induzida, e através de mecanismos distintos.

Foi possível obter no presente trabalho as seqüências completas de genes codificadores de $\beta$-1,3-glucanases isolados de cafeeiro Mundo Novo e Híbrido de 
Timor, que apresentaram características distintas e maior similaridade com genes isolados de outras plantas, do que entre si (Figuras 20 e 21 e Tabela 20). Os resultados obtidos sugerem que o indutor de resistência ASM, um análogo funcional do ácido salicílico, ativou no cv. Mundo Novo uma $\beta$-1,3-glucanase de caráter ácido, enquanto que no genótipo resistente foi observada a indução de uma $\beta$-1,3-glucanase básica em resposta à presença do patógeno. Esses resultados estão de acordo com observações feitas em outras interações planta-patógeno, nas quais a expressão de PR-proteínas acídicas está normalmente mais associada à SAR mediada por ácido salicílico (Ryals et al., 1996). Por outro lado, os genes de PR-proteínas regulados por etileno, codificam normalmente proteínas básicas (Gu et al., 2000 e Seo et al., 2003). Os resultados obtidos no presente estudo estão de acordo com essas observações, uma vez que foi detectado em Híbrido de Timor durante a resposta de resistência ativada contra o patógeno, gene codificador de enzima da biossíntese do etileno (Tabela 15).

A técnica da HSS permitiu isolar vários genes associados à resistência vertical e à resistência induzida em cafeeiro, perfazendo um total de $22 \%$ e de $16 \%$ do total de genes isolados, respectivamente. Os estudos realizados possibilitaram, também, obter um perfil dos mecanismos e respostas de defesa associadas à SAR e à resistência raçacultivar específica na interação cafeeiro-H. vastatrix. Entretanto, estudos adicionais são necessários para elucidar a função desses genes em cafeeiro. A partir das informações obtidas no presente trabalho, poderá se estudar a expressão temporal dos genes e seu papel específico na interação cafeeiro- $H$. vastatrix. Os clones de cDNA obtidos nas bibliotecas subtraídas poderão ser utilizados como sondas para estudos da expressão de genes da SAR ou da resistência vertical em cafeeiro.

A utilização de PR-proteínas ou dos respectivos genes como marcadores moleculares de resistência, especialmente da resistência sistêmica adquirida, pode-se constituir em uma importante ferramenta para auxiliar o desenvolvimento de estratégias visando o controle de doenças de plantas. As informações obtidas no presente estudo poderão, também, ser utilizadas no melhoramento genético assistido por marcadores moleculares e para o desenvolvimento de plantas geneticamente modificadas visando resistência contra fitopatógenos. 


\section{CONCLUSÕES}

1. O acibenzolar-S-metil (ASM) na concentração de $200 \mu \mathrm{g}$ de i.a./mL induziu aumentos de atividade das enzimas quitinases e $\beta$-1,3-glucanases (PR-proteínas) e resistência local e sistêmica em cafeeiro suscetível cultivar Mundo Novo contra a ferrugem causada pelo fungo $H$. vastatrix. A indução dessas PR-proteínas nos tecidos foliares mostrou estar associada à expressão da resistência local e sistêmica, ativada por ASM em cafeeiro contra o patógeno. A resistência e atividades enzimáticas foram rapidamente induzidas no cafeeiro suscetível pelo ASM, sendo expressas após um dia do tratamento com o indutor e perdurando pelo menos três semanas.

2. Estudos moleculares, utilizando duas bibliotecas subtraídas contendo cada uma 384 clones de cDNA e produzidas através da técnica de hibridização subtrativa por supressão (HSS), permitiram a identificação de genes associados à resistência sistêmica adquirida (SAR) ativada pelo ASM no cafeeiro suscetível cv. Mundo Novo e à resistência vertical, observada no genótipo resistente Híbrido de Timor após a inoculação com $H$. vastatrix.

3. Foram isolados genes apresentando funções similares relacionadas à defesa de plantas contra fitopatógenos, tanto na interação incompatível Híbrido de Timor - $H$. vastatrix, como no cafeeiro Mundo Novo com resistência induzida. Os genes detectados estão implicados em diferentes processos como: estresse oxidativo, resposta de hipersensibilidade, morte celular programada, síntese de proteínas antimicrobianas, síntese e transporte de compostos antimicrobianos do metabolismo secundário, 
percepção e transdução de sinal, síntese de proteínas relacionadas à patogênese, metabolismo de lipídeos e degradação controlada de proteínas.

4. Os resultados obtidos, indicaram diferenças no perfil dos genes isolados, sugerindo que, as resistências ativadas em Mundo Novo por ASM e em Híbrido de Timor em resposta à $H$. vastatrix ocorrem através de mecanismos distintos. Foi identificado na interação incompatível, Híbrido de Timor - H. vastatrix, um número maior de genes implicados em mecanismos de defesa (22\%), do que no cultivar suscetível Mundo Novo com resistência induzida pelo ASM (16\%). No Híbrido de Timor inoculado com $H$. vastatrix houve ativação de uma maior diversidade de vias de transdução de sinal (44\%) do que no Mundo Novo tratado com ASM (30\%), refletindo uma maior complexidade da resistência ativada biologicamente do que quimicamente. $\mathrm{O}$ mecanismo de restrição do desenvolvimento do patógeno envolve principalmente a síntese e transporte de compostos antimicrobianos do metabolismo secundário (23\%) em Híbrido de Timor inoculado com $H$. vastatrix. A resistência induzida pelo ASM no cultivar suscetível Mundo Novo está mais associada com a expressão de PR-proteínas antimicrobianas (22\%), do que a resistência vertical observada no cafeeiro resistente Híbrido de Timor inoculado com o patógeno (6\%).

5. Foram obtidas as seqüências completas de genes codificadores de $\beta$-1,3glucanases ativados em cafeeiro Mundo Novo pelo indutor de resistência ASM e em Híbrido de Timor pelo patógeno H. vastatrix, através da técnica RACE (amplificação rápida das extremidades de cDNA), com base nas seqüências parciais determinadas para os respectivos clones de cDNA presentes nas bibliotecas subtraídas obtidas no presente estudo. As seqüências de cafeeiro apresentaram maior similaridade com genes isolados de outras plantas, do que entre si. As propriedades estimadas para as proteínas codificadas por esses genes indicaram que a $\beta$-1,3-glucanase isolada de Híbrido de Timor apresenta um peso molecular de cerca de 34 kDa e caráter básico, enquanto que a de Mundo Novo possui peso molecular de cerca de $50 \mathrm{kDa}$ e caráter ácido. As seqüências completas de cDNAs para os genes codificadores de $\beta$-1,3-glucanases de 
cafeeiro Mundo Novo ( $\mathrm{n}^{\circ}$ de acesso: AY389812) e de Híbrido de Timor ( ${ }^{\circ}$ de acesso: AY389811) foram depositadas no "National Center for Biotechnology Information" (NCBI), EUA. 
ANEXOS 


NeBI
Search

ᄃ 1: AY389811. Coffea arabica x ...[gi:37223497]

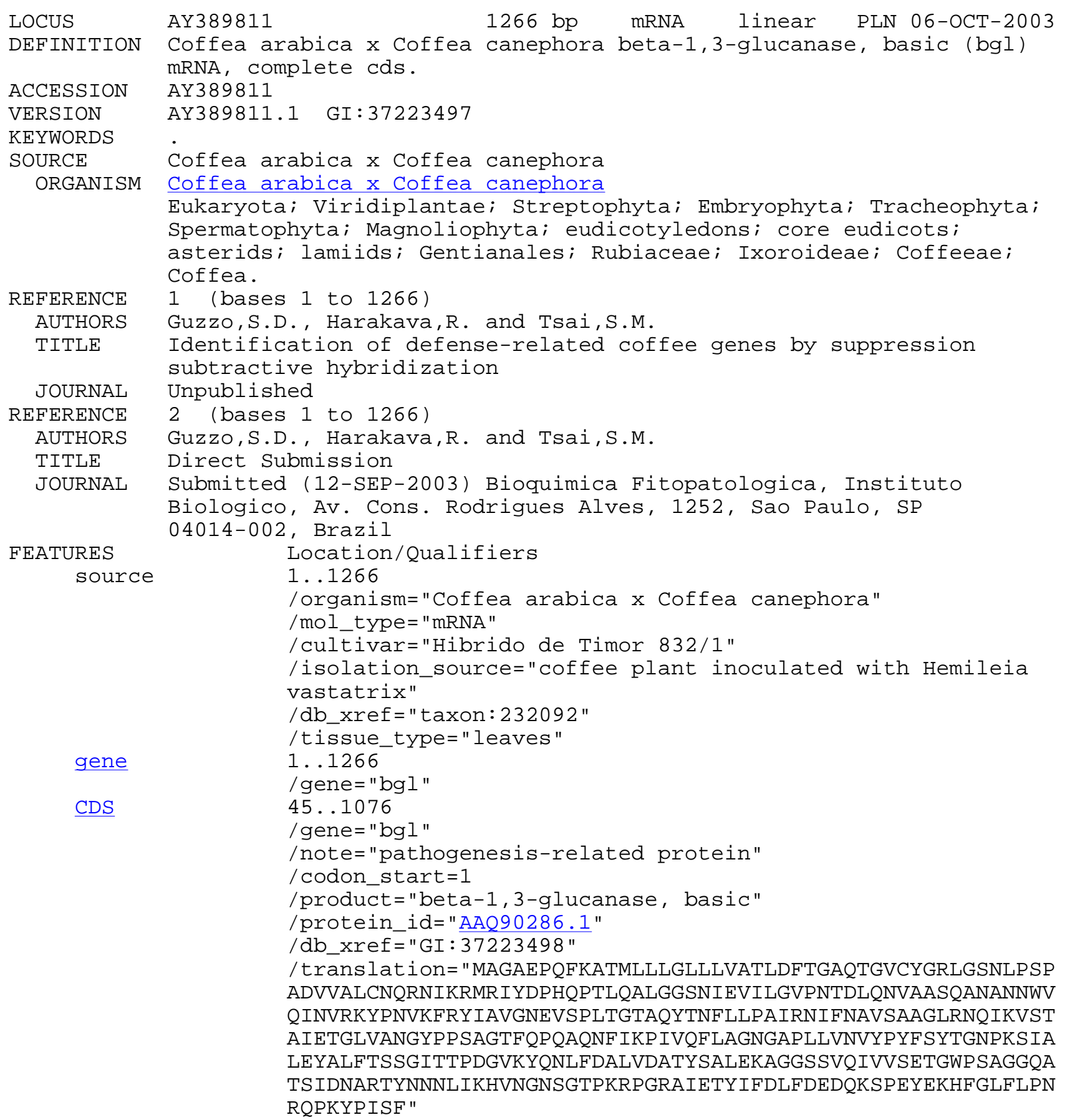


ORIGIN

1 aactaacatt aagtagtacc taaatattgc tcgtttcatt gtccatggct ggtgcagaac

61 cacaattcaa ggccactatg cttctcctcg gcctgcttt agttgcaacc cttgatttta

121 caggggctca aacaggagtt tgttatggaa ggcttggaag taatcttcca tctccagcag

181 atgttgtcgc cctgtgcaac caaagaaaca tcaaaagaat gcgaatctat gatcctcatc

241 aacccaccct tcaagccctt ggaggttcaa acattgaagt cattcttggg gttcccaaca

301 ccgatctaca gaatgttgct gcaagccaag ctaatgcaaa taattgggtt caaatcaacg

361 tcaggaagta tcccaacgtc aaattcaggt acattgcagt tggaaatgaa gtcagcccac

421 taacagggac ggctcagtac acaaactttc ttctccctgc catcagaaac atcttcaacg

481 cagtttctgc agcggggctc agaaaccaga tcaaagtttc cactgctatt gaaactggac

541 tagttgcaaa tggttatcct ccatcagctg gcactttcca acctcaagct caaaattta

601 tcaagcccat tgttcagttc ttagctggca acggtgcccc attactcgtt aatgtatatc

661 catacttttc ctacacaggc aatcccaaga gcatagctct tgaatatgct cttttacat

721 cttcgggcat caccacacca gatggtgtga agtatcaaaa tcttttgat gctctcgtgg

781 atgcaacata ctcggcgctc gaaaaggctg gaggctcatc agtccaaatt gttgtatcgg

841 agactggttg gccatcagct gggggacaag cgacatcaat agacaatgcc aggacttaca

901 acaataacct gatcaagcat gtcaatggga attctggaac cccaaaaagg cctggaaggg

961 ctattgagac ttacatttt gatttgtttg atgaagatca aaagagtcca gaatatgaga

1021 agcattttgg gctctttctt ccaaataggc agccaaagta cccaatcagt ttctaactag

1081 attgaggaat caactgtata acaggaataa ggacagatag actccatctg ttgcctctcc

1141 tgcttttatc aattgtcatc tcaaataagg gttgctctaa taatttctag ccttggcaac

1201 gtatgcgtga ataaacacaa atttttgct gctggaacaa aaaaaaaaa aaaaaaaaa 1261 aaaaaa

Disclaimer | Write to the Help Desk

$\underline{\mathrm{NCBI}}|\underline{\mathrm{NLM}}| \underline{\mathrm{NIH}}$ 




ᄃ 1: AY389812. Coffea arabica be...[gi:37223499]

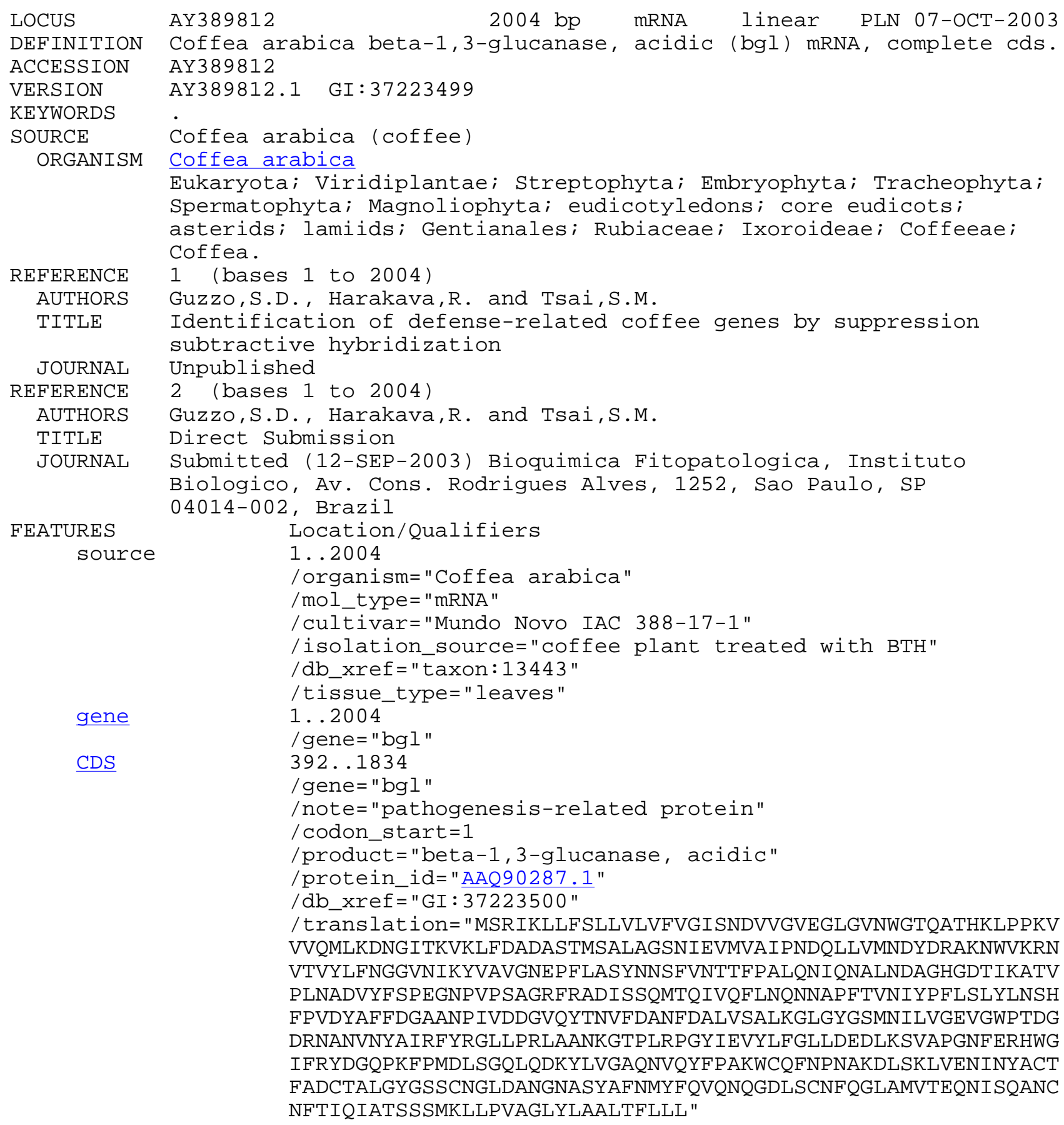


ORIGIN

1 attcacattc gtcataaaag cttttccgtt tttctcggat atagttatta gtatct gat

61 ttattcacaa aatgatatt ggggttttct tattcattg attacttgga aaaaacatt

121 ggattttggc tgattttcg tacccacctg ccaaaatcca tttctttctt ttcttttct

181 tataaatctg aatccctcct ctttgtttt ttcttttct ttttgtccct cttctcttct

241 ctttttttt ttttttattt gacaaaaaga agaggaacct ttatttatct tgaaaaagtc

301 ttggttcaca agtgataaag attgtatttt tactcatagg gaataataaa ttcctctgca

361 gggctgatt tcagttctt tttggctgaa gatgtcaaga ataaagctt tatt agctt

421 gttggtattg gtatttgttg ggattagtaa tgatgtggtg ggtgttgaag ggcttggtgt

481 gaactggggt acacaggcaa cgcacaagtt gcctcctaag gtggtagtgc aaatgctgaa

541 agacaatgga ataacaaaag tgaaactgtt tgatgcagac gcatcaacta tgagtgctct

601 ggctggctct aatattgaag taatggttgc tattcctaat gaccagcttc ttgttatgaa

661 tgactacgat agagctaaga actgggttaa gcgcaatgtc actgtctacc ttttcaatgg

721 aggtgttaac ataaagtatg tagcagttgg taatgagcca tttcttgcat cttacaataa

781 ctcattcgtg aacaccacat tcccagccct tcagaacata caaaacgccc taaatgatgc

841 tgggcatggt gacaccataa aggcaactgt gccgttaaat gctgatgtct attttcacc

901 agaaggcaat cctgttccct ctgctggaag atttcgggca gatatcagtt cccaaatgac

961 ccagattgtt cagttcttga accaaaataa tgcaccttt actgtaaata tttaccctt

1021 cttgagtctt tacttaaact cacacttccc agttgactat gccttctttg atggggctgc

1081 taaccccata gttgatgatg gagttcagta cacaaatgtc ttcgatgcca actttgatgc

1141 cttggtttca gcactaaagg gattggggta tggaagcatg aatattttgg ttggagaggt

1201 tggatggccc actgatgggg acaggaatgc caatgtaaat tatgctatta ggtttacag

1261 gggtcttctc ccaagacttg ccgcaaataa aggaacccca cttcggcctg gttatataga

1321 ggtttacttg tttggacttc tagatgaaga tttgaagagt gtagctcctg gtaattttga

1381 gcgccattgg gggattttca ggtacgatgg acagcccaag tttcctatgg atctttcagg

1441 tcagttgcaa gacaaatatc ttgtgggggc gcagaatgtg cagtattttc ctgctaaatg

1501 gtgccagttc aatcctaatg caaaagactt gagcaaactc gttgagaata tcaattatgc

1561 ttgcacattt gcagattgca cagctcttgg gtatggttcg tcttgtaatg gtttggatgc

1621 caatgggaat gcatcatatg catttaatat gtacttccag gtccagaacc aaggagatt

1681 gagctgcaat tttcaaggtt tagctatggt gactgagcag aacatatctc aagcaaattg

1741 caacttcacc attcaaattg cgacctcttc ttctatgaag ttgttgccgg tagctggatt

1801 atatttagca gcattaacat ttctattgct ataggcatct ttctgtagat acctcacatg

1861 tattatttt gatacattca tttgaggcaa taatttatac taatacagct gggcccttt

1921 ttgccctgca gattcatttg ataaaaaaaa aaaaaaaaaa aaaaaaaaa aaaaaaaaa

1981 aaaaaaaaaa aaaaaaaaaa aaaa 


\section{REFERÊNCIAS BIBLIOGRÁFICAS}

ALI, G.S.; REDDY, V.S.; LINDGREN, P.B.; JAKOBEK, J.L.; REDDY, A.S. Differential expression of genes encoding calmodulin-binding proteins in response to bacterial pathogens and inducers of defense responses. Plant Molecular Biology, v.51, n.6, p.803-815, 2003.

ALTSCHUL, S.F.; MADDEN, T.L.; SCHÄFFER, A.A.; ZHANG, J.; ZHANG, Z; MILLER, W.; LIPMAN, D.J. Gapped BLAST and PSI-BLAST: a new generation of protein database search programs. Nucleic Acids Research, v.25, p.3389-3402, 1997.

ALVAREZ, M.E.; PENNELL, R.I.; MEIJER, P.-J.; ISHIKAWA, A.; DIXON, R.A.; LAMB, C. Reactive oxygen intermediates mediate a systemic signal network in the establishment of plant immunity. Cell, v.92, p.773-784, 1998.

BAYSAL, Ö.; SOYLU, E.M.; SOYLU, S. Induction of defence-related enzymes and resistance by the plant activator acibenzolar-S-methyl in tomato seedlings against bacterial canker caused by Clavibacter michiganensis ssp.michiganensis. Plant Pathology, v.52, n.6, p.747-753, 2003.

BECKER, J.; KEMPF, R.; JEBLICK, W.; KAUSS, H. Induction of competence for elicitation of defense responses in cucumber hypocotyls requires proteasome activity. The Plant Journal, v.21, n.3, p.311-316, 2000.

BENHAMOU, N.; THERIAULT, G. Treatment with chitosan enhances resistance of tomato plants to the crown and root rot pathogen Fusarium oxysporum $\mathrm{f}$. sp.radicis-lycopersici. Physiological and Molecular Plant Pathology, v.41, p.33-52, 1992. 
BENHAMOU, N.; BÉLANGER, R.R. Benzothiadiazole-mediated induced resistance to Fusarium oxysporum f. sp.radicis-lycopersici in tomato. Plant Physiology, v.118, p.1203-1212, 1998.

BENHAMOU, N.; LAFONTAINE, P.J.; NICOLE, M. Induction of systemic resistance of Fusarium crown and root rot in tomato plants by seed treatment with chitosan. Phytopathology, v.84, p.1432-1444, 1994.

BERKELEY, M.J. The Gardeners' Chronicle. The Gardeners Chronicle and Agricultural Gazette, London, 06 Nov. 1869. p.11.

BESSER, K.; JAROSH, B.; LANGEN, G.; KOGEL, K.-H. Expression analysis of genes induced in barley after chemical activation reveals distinct disease resistance pathways. Molecular Plant Pathology, v.1, n.5, p.277-286, 2000.

BETTENCOURT, A.J. Melhoramento genético do cafeeiro. Transferência de fatores de resistência à Hemileia vastatrix Berk. et Br. para os principais cultivares de Coffea arabica L. Lisboa: Junta de Investigações Científicas do Ultramar CIFC, 1981. 93p.

BETTENCOURT, A.J. Características agronômicas de seleções derivadas de cruzamentos entre Híbrido de Timor e as variedades Caturra, Vila Sarchi e Catuaí. In: SIMPÓSIO SOBRE FERRUGENS DO CAFEEIRO, Oeiras, 1983. Comunicações. Oeiras - Portugal: CIFC, 1984. p.353-371.

BIRCH, P.R.J.; AVROVA, A.O.; DUNCAN, J.M.; LYON, G.D.; TOTH, R.L. Isolation of potato genes that are induced during an early stage of the hypersensitive response to Phytophthora infestans. Molecular Plant-Microbe Interactions, v.12, n.4, p.356-361, 1999.

BIRNBOIM, H.C.; DOLY, J. A rapid alkaline extraction procedure for screening recombinant plasmid DNA. Nucleic Acids Research, v.7, n.6, p.1513-1523, 1979.

BOKSHI, A.I.; MORRIS, S.C.; DEVERALL, B.J. Effects of benzothiadiazole and acetylsalicylic acid on $\beta$-1,3-glucanase activity and disease resistance in potato. Plant Pathology, v.52, n.1, p.22-27, 2003. 
BOL, J.F.; LINTHORST, H.J.M.; CORNELISSEN, B.J.C. Plant pathogenesisrelated proteins induced by virus infection. Annual Review of Phytopathology, v.28, p.113-138, 1990.

BOLLER, T. Hydrolytic enzymes in plant disease resistance. In: KOSUGE, T.; NESTER, E.W. (Ed.) Plant-microbe interactions, molecular and genetic perspectives. New York: Macmillan, 1987. v.2, p.385-413.

BORDEN, S.; HIGGINS, V.J. Hydrogen peroxide plays a critical role in the defense response of tomato to Cladosporium fulvum. Physiological and Molecular Plant Pathology, v.61, n.4, p.227-236, 2002.

BOSTOCK, R.M.; KARBAN, R.; THALER, J.S.; WEYMAN, P.D.; GILCHRIST, D. Signal interactions in induced resistance to pathogens and insect herbivores. European Journal of Plant Pathology, v.107, p.103-111, 2001.

BRADFORD, M.M. A rapid and sensitive method for quantification of microgram quantities of protein utilizing the principle of protein-dye binding. Analytical Biochemistry, v.72, p.248-254, 1976.

BREUSEGEM, F.V.; VRANOVÁ, E.; DAT, J.F.; INZÉ, D. The role of active oxygen species in plant signal transduction. Plant Science, v.161, p.405-414, 2001.

BUFE, A.; SPANGFORT, M.D.; KAHLERT, H.; SCHLAAK, M.; BECKER, W.-M. The major birch pollen allergen BetvI, shows ribonuclease activity. Planta, v.199, p.413-415, 1996.

BURKETOVA, L.; SINDELAROVA, M.; SINDELAR, L. Benzothiadiazole as an inducer of $\beta$-1,3-glucanase and chitinase isozymes in sugar beet. Biologia Plantarum, v.42, n.2, p.279-287, 1999.

BUSAM, G.; KASSEMEYER, H.H.; MATERN, U. Differential expression of chitinases in Vitis vinifera L. responding to systemic acquired resistance activators or fungal challenge. Plant Physiology, v.115, p.1029-1038, 1997. 
BUZI, A.; CHILOSI, G.; DE SILLO, D.; MAGRO, P. Induction of resistance in melon to Didymella bryoniae and Sclerotinia sclerotiorum by seed treatments with acibenzolar-S-methyl and methyl jasmonate but not with salicylic acid. Journal of Phytopathology, v.152, n.1, p.34-42, 2004.

CAPDEVILLE, G. DE; BEER, S.V.; WATKINS, C.B.; WILSON, C.L.; TEDESCHI, L.O.; AIST, J.R. Pre- and post-harvest Harpin treatments of apples induce resistance to blue mold. Plant Disease, v.87, n.1, p.39-44, 2003.

CARVALHO, A.; MÔNACO, L.C. Transferência do fator caturra para o cultivar Mundo Novo de Coffea arabica. Bragantia, v.31, p.379-399, 1972.

CHENCHIK, A.; ZHU, Y.Y.; DIATCHENKO, L.; LI, R.; HILL, J.; SIEBERT, P. Generation and use of high quality cDNA from small amounts of total RNA by SMART PCR. In: SIEBERT, P.; LARRICK, J.W. (Ed.) Gene cloning and analysis by RT-PCR. Westborough: BioTechniques Press, 1998. p.305-319.

CHESTER, K.S. The problem of acquired physiological immunity in plants. Quarterly Review of Biology, v.8, p.275-324, 1933.

CHOMCZYNSKI, P.; SACCHI, N. Single-step method of RNA isolation by acid guanidinium thiocyanate-phenol-chloroform extraction. Analytical Biochemistry, v.162, n.1, p.156-159, 1987.

CLONTECH LABORATORIES. CLONTECH PCR-Select cDNA subtraction kit user manual. Palo Alto, 2000a. 47p.

CLONTECH LABORATORIES. SMART PCR cDNA synthesis kit user manual. Palo Alto, 2000b. 39p.

CLONTECH LABORATORIES. PCR-Select differential screening kit user manual. Palo Alto, 2001a. 32p.

CLONTECH LABORATORIES. SMART RACE cDNA amplification kit user manual. Palo Alto, 2001b. 39p.

COHEN, Y.; GISI, U.; MÖSINGER, E. Systemic resistance of potato plants against Phytophthora infestans induced by unsaturated fatty acids. Physiological and Molecular Plant Pathology, v.38, p.255-263, 1991. 
COHEN, Y.; REUVENI, M.; BAIDER, A. Local and systemic activity of BABA (DL-3-aminobutyric acid) against Plasmopara viticola in grapevines. European Journal of Plant Pathology, v.105, n.4, p.351-361, 1999.

CONRATH, U.; PIETERSE, C.M.J.; MAUCH-MANI, B. Priming in plant-pathogen interactions. Trends in Plant Science, v.7, n.5, p.210-216, 2002.

COQUOZ, J.L.; BUCHALA, A.J.; MEUWLY, P.; MÉTRAUX, J.-P. Arachidonic acid treatment of potato plants induces local synthesis of salicylic acid and confers systemic resistance to Phytophthora infestans and Alternaria solani. Phytopathology, v.85, p.1219-1224, 1995.

CRUICKSHANK, I.A.M.; MANDRYK, A. The effect of stem infestations of tobacco with Peronospora tabacina Adam on foliage reaction to blue mold. Journal of Australian Agricultural Science, v.26, p.369-372, 1960.

DAHAN, J.; ETIENNE, P.; PETITOT, A.-S.; HOUOT, V.; BLEIN, J.-P.; SUTY, L. Cryptogein affects expression of $\alpha 3, \alpha 6$ and $\beta 120 \mathrm{~S}$ proteasome subunits encoding genes in tobacco. Journal of Experimental Botany, v.52, n.362, p.1947-1948, 2001.

DANN, E.K.; MEUWLY, P.; MÉTRAUX, J.-P.; DEVERALL, B.J. The effect of pathogen inoculation or chemical treatment on activities of chitinase and $\beta-1,3-$ glucanase and accumulation of salicylic acid in leaves of green bean, Phaseolus vulgaris L. Physiological and Molecular Plant Pathology, v.49, n.5, p.307-319, 1996.

DAVIES, C.; ROBINSON, S.P. Differential screening indicates a dramatic change in mRNA profiles during grape berry ripening. Cloning and characterization of cDNAs encoding putative cell wall and stress response proteins. Plant Physiology, v.122, n.3, p.803-812, 2000.

DEAN, R.; KUĆ, J. Induced systemic protection in cucumber: The source of the “signal”. Physiological and Molecular Plant Pathology, v.28, p.227-233, 1986. 
DELANEY, T.P.; FRIEDRICH, L.; RYALS, J.A. Arabidopsis signal transduction mutant defective in chemically and biologically induced disease resistance. Proceedings of the National Academy of Sciences of the USA, v.92, p.66026606, 1995.

DELlagi, A.; HEILBRONN, J.; AVROVA, A.O.; MONTESANO, M.; PALVA, E.T.; STEWART, H.E.; TOTH, I.K.; COOKE, D.E.L.; LYON, G.D.; BIRCH, P.R.J. A potato gene encoding a WRKY-like transcription factor is induced in interactions with Erwinia carotovora subsp.atroseptica and Phytophthora infestans and is coregulated with class I endochitinase expression. Molecular Plant-Microbe Interactions, v.13, n.10, p.1092-1101, 2000.

DESIKAN， R.; A.-H.-MACKERNESS， S.; HANCOCK, J.T.; NEILL， S.J. Regulation of the Arabidopsis transcriptome by oxidative stress. Plant Physiology, v.127, p.159-172, 2001.

DIATCHENKO, L.; CHENCHIK, A.; SIEBERT, P. Suppression subtractive hybridization: a method for generating subtracted cDNA libraries starting from poly(A+) or total RNA. In: SIEBERT, P.; LARRICK, J.W. (Ed.) Gene cloning and analysis by RT-PCR. Westborough: BioTechniques Press, 1998. p.213239.

DIATCHENKO, L.; LAU, Y.-F.C.; CAMPBELL, A.P.; CHENCHIK, A.; MOQADAM, F.; HUANG, B.; LUKYANOV, S.; LUKYANOV, K.; GURSKAYA, N.; SVERDLOV, E.D.; SIEBERT, P.D. Suppression subtractive hybridization: A method for generating differentially regulated or tissue-specific cDNA probes and libraries. Proceedings of the National Academy of Sciences of the USA, v.93, p.6025-6030, 1996.

DITTRICH, H.; KUTCHAN, T.M. Molecular cloning, expression, and induction of berberine bridge enzyme, an enzyme essential to the formation of benzophenanthridine alkaloids in the response of plants to pathogenic attack. Proceedings of the National Academy of Sciences of the USA, v.88, n.22, p.9969-9973, 1991. 
DO, H.M.; HONG, J.K.; JUNG, H.W.; KIM, S.H.; HAM, J.H.; HWANG, B.K. Expression of peroxidase-like genes, $\mathrm{H}_{2} \mathrm{O}_{2}$ production and peroxidase activity during the hypersensitive response to Xanthomonas campestris pv.vesicatoria in Capsicum annuum. Molecular Plant-Microbe Interactions, v.16, n.3, p.196205, 2003.

DOKE, N.; RAMIREZ, A.V.; TOMIYAMA, K. Systemic induction of resistance in potato plants against Phytophthora infestans by local treatment with hyphal wall components of the fungus. Journal of Phytopathology, v.119, p.232-239, 1987.

ESQUERRÉ-TUGAYÉ, M-T.; BOUDART, G.; DUMAS, B. Cell wall degrading enzymes, inhibitory proteins, and oligosaccharides participate in the molecular dialogue between plants and pathogens. Plant Physiology and Biochemistry, v.38, n.1-2, p.157-163, 2000.

ETIENNE, P.; PETITOT, A.-S.; HOUOT, V.; BLEIN, J.-P.; SUTY, L. Induction of tcI 7 , a gene encoding a $\beta$-subunit of proteasome, in tobacco plants treated with elicitins, salicylic acid or hydrogen peroxide. FEBS Letters, v.466, n.2/3, p.213$218,2000$.

FARMER, E.E.; RYAN, C.A. Octadecanoid precursors of jasmonic acid activate the synthesis of wound-inducible proteinase inhibitors. Plant Cell, v.4, p.129-134, 1992.

FAZUOLI, L.C. Avaliação de progênies de café Mundo Novo (Coffea arabica L.) Piracicaba, 1977. 146p. Dissertação (Mestrado) - Escola Superior de Agricultura "Luiz de Queiroz", Universidade de São Paulo.

FAZUOLI, L.C.; MEDINA FILHO, H.P.; GONÇALVES, W.; GUERREIRO FILHO, O.; SILVAROLLA, M.B. Melhoramento do cafeeiro: variedades tipo arábica obtidas no Instituto Agronômico de Campinas. In: ZAMBOLIM, L. (Ed.) O estado da arte de tecnologias na produção de café. Viçosa: UFV, 2002. cap.5, p.163-215.

FOUGHT, L.; KUĆ, J. Lack of specificity in plant extracts and chemicals as inducers of systemic resistance in cucumber pants to anthracnose. Journal of Phytopathology, v.144, p.1-6, 1996. 
FRIEDRICH, L.; LAWTON, K.; RUESS, W.; MASNER, P.; SPECKER, N.; GUTRELlA, M.; MEIER, B.; DINCHER, S.; STAUB, T.; UKNES, S.; MÉTRAUX, J.-P.; KESSMANN, H.; RYALS, J. A benzothiadiazole derivative induces systemic acquired resistance in tobacco. Plant Journal, v.10, p.61-70, 1996.

FRITIG, B.; HEITZ, T.; LEGRAND, M. Antimicrobial proteins in induced plant defense. Current Opinion in Immunology, v.10, p.16-22, 1998.

GAFFNEY, T.; FRIEDRICH, L.; VERNOOIJ, B.; NEGRETTO, D.; NYE, G.; UKNES, S.; WARD, E.; KESSMANN, H.; RYALS, J. Requirement of salicylic acid for the induction of systemic acquired resistance. Science, v.261, p.754-756, 1993.

GENOUD, T.; MÉTRAUX, J.-P. Crosstalk in plant cell signaling: structure and function of the genetic network. Trends in Plant Science, v.4, p.503-507, 1999.

GLAZEBROOK, J. Genes controlling expression of defense responses in Arabidopsis. Current Opinion in Plant Biology, v.2, p.280-286, 1999.

GÖRLACH, J.; VOLRATH, S.; KNAUF-BEITER, G.; HENGY, G.; BECKHOVE, U.; KOGEL, K.H.; OOSTENDORP, M.; STAUB, T.; WARD, E.; KESSMANN, H.; RYALS, J. Benzothiadiazole, a novel class of inducers of systemic acquired resistance, activates gene expression and disease resistance in wheat. Plant Cell, v.8, p.629-643, 1996.

GOTTSTEIN, H.D.; KUĆ, J.A. Induction of systemic resistance to anthracnose in cucumber by phosphates. Phytopathology, v.79, p.176-179, 1989.

GRANT, J.J.; LOAKE, G.J. Role of Reactive oxygen intermediates and cognate redox signaling in disease resistance. Plant Physiology, v.124, n.1, p.21-30, 2000.

GU, Y.-Q.; YANG, C.; THARA, V.K.; ZHOU, J.; MARTIN, G.B. Pti4 is induced by ethylene and salicylic acid, and its product is phosphorylated by the Pto kinase. The Plant Cell, v.12, p.771-785, 2000. 
GUERRA-GUIMARÃES, L.; SILVA, M.C.; NICOLE, M.; AZINHEIRA, H.G.; RODRIGUES JUNIOR, C.J.; PINTO RICARDO, C. Chitinase activity associated with coffee-rust interaction. In: CONGRESS OF THE MEDITERRANEAN PHYTOPATHOLOGICAL UNION, 11.; CONGRESS OF THE SOCIEDADE PORTUGUESA DE FITOPATOLOGIA, 3., Évora, Portugal, 2001. Proceedings. Évora, 2001. p.356-358.

GUEVARA, M.G.; OLIVA, C.R.; HUARTE, M.; DALEO, G.R. An aspartic protease with antimicrobial activity is induced after infection and wounding in intercellular fluids of potato tubers. European Journal of Plant Pathology, v.108, n.2, p.131-137, 2002.

GUZZO, S.D.; MARTINS, E.M.F. Local and systemic induction of $\beta-1,3$-glucanase and chitinase in coffee leaves protected against Hemileia vastatrix by Bacillus thuringiensis. Journal of Phytopathology, v.144, n.9/10, p.449-454, 1996.

GUZZO, S.D.; CASTRO, R.M. DE; KIDA, K.; MARTINS, E.M.F. Ação protetora do acibenzolar-S-methyl em plantas de cafeeiro contra ferrugem. Arquivos do Instituto Biológico, v.68, n.1, p.89-94, 2001.

HAMMERSCHMIDT, R.; MÉTRAUX, J.-P.; VAN LOON, L.C. Inducing resistance: a summary of papers presented at the First International Symposium on Induced Resistance to Plant Diseases, Corfu, May 2000. European Journal of Plant Pathology, v.107, n.1, p.1-6, 2001.

HAMMOND-KOSACK, K.E.; JONES, J.D.G. Resistance gene-dependent plant defense responses. The Plant Cell, v.8, p.1773-1791, 1996.

HAMMOND-KOSACK, K.; JONES, J.D.G. Responses to plant pathogens. In: BUCHANAN, B.B.; GRUISSEM, W.; JONES, R.L. (Ed.) Biochemistry and molecular biology of plants. Rockville: American Society of Plant Biologists, 2000. chap.21, p.1102-1157.

HE, C.Y.; HSIANG, T.; WOLYN, D.J. Induction of systemic disease resistance and pathogen defence responses in Asparagus officinalis inoculated with nonpathogenic strains of Fusarium oxysporum. Plant Pathology, v.51, n.2, p.225-230, 2002. 
HEATH, M.C. Hypersensitive response-related death. Plant Molecular Biology, v.44, n.3, p.321-334, 2000.

HEIL, M.; BOSTOCK, R.M. Induced systemic resistance (ISR) against pathogens in the context of induced plant defenses. Annals of Botany, v.89, p.503-512, 2002.

HEITZ, T.; FRITIG, B.; LEGRAND, M. Local and systemic accumulation of pathogenesis-related proteins in tobacco plants infected with tobacco mosaic virus. Molecular Plant-Microbe Interactions, v.7, p.776-779, 1994.

HUCKELHOVEN, R.; DECHERT, C.; TRUJILlO, M.; KOGEL, K.H. Differential expression of putative cell death regulator genes in near-isogenic, resistant and susceptible barley lines during interaction with the powdery mildew fungus. Plant Molecular Biology, v.47, n.6, p.739-748, 2001.

HWANG, B.K.; SUNWOO, J.Y.; KIM, Y.J.; KIM, B.S. Accumulation f $\beta$-1,3glucanase and chitinase isoforms, and salicylic acid in the DL- $\beta$-amino-n-butyric acid-induced resistance response of pepper stems to Phytophthora capsici. Physiological and Molecular Plant Pathology, v.51, n.5, p.305-322, 1997.

INBAR, M.; DOOSTDAR, H.; SONODA, R.M.; LEIBEE, G.L.; MAYER, R.T. Elicitors of plant defensive systems reduce insect densities and disease incidence. Journal of Chemical Ecology, v.24, n.1, p.135-149, 1998.

INGVARDSEN, C.; VEIERSKOV, B. Ubiquitin- and proteasome-dependent proteolysis in plants. Physiologia Plantarum, v.112, n.4, p.451-459, 2001.

IRITI, M.; FAORO, F. Benzothiadiazole (BTH) induces cell-death independent resistance in Phaseolus vulgaris against Uromyces appendiculatus. Journal of Phytopathology, v.151, n.3, p.171-180, 2003.

JAKAB， G.; COTTIER， V.; TOQUIN， V.; RIGOLI， G.; ZIMMERLI， L.; MÉTRAUX, J.-P.; MAUCH-MANI, B. $\beta$-Aminobutyric acid-induced resistance in plants. European Journal of Plant Pathology, v.107, p.29-37, 2001.

JAKAB, G.; MANRIQUE, A.; ZIMMERLI, L.; MÉTRAUX, J.-P.; MAUCH-MANI, B. Molecular characterization of a novel lipase-like pathogen-inducible gene family of Arabidopsis. Plant Physiology, v.132, p.1-10, 2003. 
JASIŃSKI, M.; STUKKENS, Y.; DEGAND, H.; PURNELLE, B.; MARCHANDBRYNAERT, J.; BOUTRY, M. A plant plasma membrane ATP binding cassettetype transporter is involved in antifungal terpenoid secretion. The Plant Cell, v.13, p.1095-1107, 2001.

KARRER, E.E.; BEACHY, R.N.; HOLT, C.A. Cloning of tobacco genes that elicit the hypersensitive response. Plant Molecular Biology, v.36, p.681-690, 1998.

KELlER, H.; BLEIN, J.-P.; BONNET, P.; RICCI, P. Physiological and molecular characteristics of elicitin-induced systemic acquired resistance in tobacco. Plant Physiology, v.110, p.365-376, 1996.

KESSMANN, H.; STAUB, T.; HOFMANN, C.; MAETZKE, T.; HERZOG, J.; WARD, E.; UKNES, S.; RYALS, J. Induction of systemic acquired disease resistance in plants by chemicals. Annual Review of Phytopathology, v.32, p.439-459, 1994.

KIM, K.-N.; CHEONG, Y.H.; GUPTA, R.; LUAN, S. Interaction specificity of Arabidopsis calcineurin B-like calcium sensors and their target kinases. Plant Physiology, v.124, p.1844-1853, 2000.

KIM, Y.J.; HWANG, B.K. Isolation of a basic 34 kiloDalton $\beta$-1,3-glucanase with inhibitory activity against Phytophthora capsici from pepper stems. Physiological and Molecular Plant Pathology, v.50, p.103-115, 1997.

KNIGHT, V.I.; WANG, H.; LINCOLN, J.E.; LULAI, E.C.; GILCHRIST, D.G.; BOSTOCK, R.M. Hydroperoxides of fatty acids induce programmed cell death in tomato protoplasts. Physiological and Molecular Plant Pathology, v.59, n.6, p.275-325, 2001.

KOHLER, A.; SCHWINDLING, S.; CONRATH, U. Benzothiadiazole-induced priming for potentiated responses to pathogen infection, wounding, and infiltration of water into leaves requires the NPR1/NIM1 gene in Arabidopsis. Plant Physiology, v.128, n.3, p.1046-1056, 2002.

KOIWA, H.; BRESSAN, R.A.; HASEGAWA, P.M. Regulation of protease inhibitors and plant defense. Trends in Plant Science, v.2, p.379-384, 1997. 
KOMBRINK, E.; HAHLBROCK, K. Responses of cultured parsley cells to elicitors from phytopathogenic fungi. Timing and dose dependency of elicitor- induced reactions. Plant Physiology, v.81, n.1, p.216-221, 1986.

KUĆ, J. Induced immunity to plant disease. BioScience, v.32, p.854-860, 1982.

KUĆ, J. Systemic induced resistance. In: WALTERS, D.R.; SCHOLES, J.D.; BRYSON, R.J.; PAUL, N.D.; MCROBERTS, N. (Ed.) Aspects of applied biology: physiological responses of plants to pathogens. Dundee: Association of Applied Biologists, 1995. v.42, p.235-242.

KUĆ, J. Concepts and direction of induced systemic resistance in plants and its application. European Journal of Plant Pathology, v.107, p.7-12, 2001.

KUĆ, J.; SHOCKLEY, G.; KEARNEY, K. Protection of cucumber against Colletotrichum lagenarium by Colletotrichum lagenarium. Physiological Plant Pathology, v.7, p.195-199, 1975.

KUHLMANN, M.; HORVAY, K.; STRATHMANN, A.; HEINEKAMP, T.; FISCHER, U.; BOTTNER, S.; DROGE-LASER, W. The alpha-helical D1 domain of the tobacco bZIP transcription factor BZI-1 interacts with the ankyrinrepeat protein ANK1 and is important for BZI-1 function, both in auxin signaling and pathogen response. Journal of Biological Chemistry, v.278, n.10, p.87868794, 2003.

KUMAR, D.; KLESSIG, D.F. High-affinity salicylic acid-binding protein 2 is required for plant innate immunity and has salicylic acid-stimulated lipase activity. Proceedings of the National Academy of Sciences of the USA, v.100, n.26, p.16101-16106, 2003.

LAM, E.; KATO, N.; LAWTON, M. Programmed cell death, mitochondria and the plant hypersensitive response. Nature, v.411, p.848-853, 2001.

LATUNDE-DADA, A.O.; LUCAS, J.A. The plant defence activator acibenzolar-Smetyhl primes cowpea [Vigna unguiculata (L.) Walp.] seedlings for rapid induction of resistance. Physiological and Molecular Plant Pathology, v.58, n.5, p.199-208, 2001. 
LAWTON, K.; WEYMANN, K.; FRIEDRICH, L.; VERNOOIJ, B.; UKNES, S.; RYALS, J. Systemic acquired resistance in Arabidopsis requires salicylic acid but not ethylene. Molecular Plant Microbe Interactions, v.8, p.863-870, 1995.

LAWTON, K.; FRIEDRICH, L.; HUNT, M.; WEYMANN, K.; DELANEY, T.; KESSMANN, H.; STAUB, T.; RYALS, J. Benzothiadiazole induces disease resistance in Arabidopsis by activation of the systemic acquired resistance signal transduction pathway. Plant Journal, v.10, p.71-82, 1996.

LEE, S.J.; SUH, M.C.; KIM, S.; KWON, J.K.; KIM, M.; PAEK, K.H.; CHOI, D.; KIM, B.D. Molecular cloning of a novel pathogen-inducible cDNA encoding a putative acyl-CoA synthetase from Capsicum annuum L. Plant Molecular Biology, v.46, n.6, p.661-671, 2001.

LEON, J.; LAWTON, M.A.; RASKIN, I. Hydrogen peroxide stimulates salicylic acid biosynthesis in tobacco. Plant Physiology, v.108, n.4, p.1673-1678, 1995.

LEVINE, A.; TENHAKEN, R.; DIXON, R.; LAMB, C. $\mathrm{H}_{2} \mathrm{O}_{2}$ from the oxidative burst orchestrates the plant hypersensitive disease resistance response. Cell, v.79, p.583-593, 1994.

LO, S.-C.C.; HIPSKIND, J.D.; NICHOLSON, R.L. cDNA cloning of a sorghum pathogenesis-related protein (PR-10) and differential expression of defenserelated genes following inoculation with Cochliobolus heterostrophus or Colletotrichum sublineolum. Molecular Plant-Microbe Interactions, v.12, n.6, p.479-489, 1999.

MADAMANCHI, N.R.; KUĆ, J. Induced systemic resistance in plants. In: COLE, G.T.; HOCH, H.C. (Ed.) The fungal spore and disease initiation in plants and animals. New York: Plenum Press, 1991. p.347-362.

MALDONADO, A.M.; DOERNER, P.; DIXON, RA.; LAMB, C.J.; CAMERON, R.K. A putative lipid transfer protein involved in systemic resistance signaling in Arabidopsis. Nature, v.419, n.6905, p.399-403, 2002.

MARCHI, C.E.; BORGES, M.DE F.; RESENDE, M.L.V. Proteção induzida por benzotiadiazole contra a ferrugem-alaranjada (Hemileia vastatrix) em cafeeiro. Ciência e Agrotecnologia, v.26, n.5, p.1103-1106, 2002. 
MARCHLER-BAUER, A.; ANDERSON, J.B.; DEWEESE-SCOTT, C.; FEDOROVA, N.D.; GEER, L.Y.; HE, S.; HURWITZ, D.I.; JACKSON, J.D.; JACOBS, A.R.; LANCZYCKI, C.J.; LIEBERT, C.A.; LIU, C.; MADEJ, T.; MARCHLER, G.H.; MAZUMDER, R.; NIKOLSKAYA, N.A.; PANCHENKO, A.R.; RAO, B.S.; SHOEMAKER, B.A.; SIMONYAN, V.; SONG, J.S.; THIESSEN, P.A.; VASUDEVAN, S.; WANG, Y.; YAMASHITA, R.A.; YIN, J.J.; BRYANT, S.H. CDD: a curated Entrez database of conserved domain alignments. Nucleic Acids Research, v.31, n.1, p.383-387, 2003.

MARTINEZ, C.; BACCOU, J.-C.; BRESSON, E.; BAISSAC, Y.; DANIEL, J.-F.; JALlOUL, A.; MONTILLET, J.-L.; GEIGER, J.-P.; ASSIGBETSÉ, K.; NICOLE, M. Salicylic acid mediated by the oxidative burst is a key molecule in local and systemic responses of cotton challenged by an avirulent race of Xanthomonas campestris pv.malvacearum. Plant Physiology, v.122, p.757-766, 2000.

MARTINS, E.M.F. Seqüência de eventos primários do desenvolvimento de Hemileia vastatrix em folhas de cafeeiro com suscetibilidade genética, resistência induzida ou resistência genética. Piracicaba, 1988. 149p. Dissertação (Mestrado) - Escola Superior de Agricultura "Luiz de Queiroz", Universidade de São Paulo.

MARTINS, E.M.F. Controle da ferrugem do cafeeiro (Hemileia vastatrix) através da indução de resistência. In: BETTIOL, W. (Ed.) Controle biológico de doenças de plantas. Jaguariúna: EMBRAPA, CNPDA, 1991. cap.24, p.345-363.

MARTINS, E.M.F.; MORAES, W.B.C. Development of Hemileia vastatrix in coffee plants with genetic or induced resistance. Journal of Phytopathology, v.144, p.519-526, 1996.

MARTINS, E.M.F.; BERETTA, M.J.G.; ROVERATTI, D.S.; MORAES, W.B.C. Comparative induced protection to Hemileia vastatrix in coffee plants by nonspecific inducers from different fungal and bacterial origins. Fitopatologia Brasileira, v.10, p.521-529, 1985. 
MATIELLO, J.B.; SANTINATO, R.; GARCIA， A.W.R.; ALMEIDA， S.R.; FERNANDES, D.R. Cultura de café no Brasil. Novo Manual de Recomendações. In: MATIELLO, J.B. (Ed.) Rio de Janeiro: MAPA/PROCAFÉ, 2002. 387p.

MATZ, M.; LUKYANOV, S.; BOGDANOVA, E.; DIATCHENKO, L.; CHENCHIK, A. Amplification of cDNA ends based on template-switching effect and step-out PCR. Nucleic Acids Research, v.27, n.6, p.1558-1560, 1999.

MAUCH-MANI, B.; SLUSARENKO, A.J. Systemic acquired resistance in Arabidopsis thaliana induced by a predisposing infection with a pathogenic isolate of Fusarium oxysporum. Molecular Plant Microbe Interactions, v.7, p.378-383, 1994.

MAUCH-MANI, B.; MÉTRAUX, J.-P. Salicylic acid and systemic acquired resistance to pathogen attack. Annals of Botany, v.82, n.5, p.535-540, 1998.

MAXEMIUC-NACCACHE, V.; BRAGA, M.R.; DIETRICH, S.M.C. Chitinase and $\beta-1,3$-glucanase changes in compatible and incompatible combinations between coffee leaf disks and coffee rust (Hemileia vastatrix). Revista Brasileira de Botânica, v.15, p.145-150, 1992.

MÉTRAUX, J.-P. Systemic acquired resistance and salicylic acid: current state of knowledge. European Journal of Plant Pathology, v.107, p.13-18, 2001.

MÉTRAUX, J.-P., BOLLER, T.H. Local and systemic induction of chitinase in cucumber plants in response to viral, bacterial and fungal infections. Physiological and Molecular Plant Pathology, v.28, p.161-169, 1986.

MÉTRAUX, J.-P.; AHL-GOY, P.; STAUB, T.; SPEICH, J.; STEINEMANN, A.; RYALS, J.; WARD, E. Induced systemic resistance in cucumber in response to 2,6-dichloroisonicotinic acid and pathogens. In: HENNECKE, H.; VERMA, D.P.S. Advances in molecular genetics of plant-microbe interactions. Amsterdam: Kluwer Academic Publishers, 1991. v.1, p.432-439.

MITHÖFER, A.; FLIEGMANN, J.; NEUHAUS-URL, G.; SCHWARZ, H.; EBEL, J. The hepta- $\beta$-glucoside elicitor-binding proteins from legumes represent a putative receptor family. Biological Chemistry, v.381, p.705-713, 2000. 
MITTLER, R.; LAM, E.; SHULAEV, V.; COHEN, M. Signals controlling the expression of cytosolic ascorbate peroxidase during pathogen-induced programmed cell death in tobacco. Plant Molecular Biology, v.39, n.5, p.10251035, 1999.

MOERSCHBACHER, B.M. Ligninbiosynthese und die Resistenz des Weizens gegen Schwarzrost. Aachen, 1988. 193p. Tese (Doutorado) - RheinischWestfälischen Technischen Hochschule Aachen.

MORAES, W.B.C. Controle alternativo de fitopatógenos. Pesquisa Agropecuária Brasileira, v.27, p.175-190, 1992.

MORAES, W.B.C.; MARTINS, E.M.F.; MUSUMECI, M.R.; BERETTA, M.J.G. Induced protection to Hemileia vastatrix in coffee plants. S umma Phytopathologica, v.2, p.39-43, 1976.

MORRIS, S.W.; VERNOOIJ, B.; TITATARN, S.; STARRETT, M.; THOMAS, S.; WITSE, C.C.; FREDERIKSEN, R.A.; BHADHUFALCK, A.; HULBERT, S.; UKNES, S. Induced resistance responses in maize. Molecular Plant-Microbe Interactions, v.11, n.7, p.643-658, 1998.

NADIMPALLI, R.; YALPANI, N.; GURMUKH, S.J.; SIMMONS, C.R. Prohibitins, stomatins, and plant disease response genes compose a protein superfamily that controls cell proliferation, ion channel regulation, and death. The Journal of Biological Chemistry, v.275, n.38, p.29579-29586, 2000.

NAKAI, K.; KANEHISA, M. A knowledge base for predicting protein localization sites in eukaryotic cells. Genomics, v.14, p.897-911, 1992.

NANDI, A.; KROTHAPALLI, K.; BUSEMAN, C.M.; LI, M.; WELTI, R.; ENYEDI, A.; SHAH, J. Arabidopsis sfd mutants affect plastidic lipid composition and suppress dwarfing, cell death, and the enhanced disease resistance phenotypes resulting from the deficiency of a fatty acid desaturase. The Plant Cell, v.15, p.2383-2398, 2003. 
NARUSAKA, Y.; NARUSAKA, M.; HORIO, T.; ISHII, H. Comparison of local and systemic induction of acquired disease resistance in cucumber plants treated with benzothiadiazoles or salicylic acid. Plant and Cell Physiology, v.40, n.4, p.388395, 1999.

NAWRATH, C.; MÉTRAUX, J.-P. Salicylic acid induction-deficient mutants of Arabidopsis express PR-2 and PR-5 and accumulate high levels of camalexin after pathogen inoculation. Plant Cell, v.11, p.1393-1404, 1999.

NELSON, M.A.; KANG, S.; BRAUN, E.L.; CRAWFORD, M.E.; DOLAN, P.L.; LEONARD, P.M.; MITCHELL, J.; ARMIJO, A.M.; BEAN, L.; BLUEYES, E.; CUSHING, T.; ERRET, A.; FLEHARTY, M.; GORMAN, M.; JUDSON, K.; MILlER, R.; ORTEGA, J.; PAVlOVA, I.; PEREA, J.; TODISCO, S.; TRUJILLO, R.; VALENTINE, J.; WELLS, A.; WERNER-WASHBURNE, M.; YAZZIE, S.; NATVIG, D. Expressed sequences from conidial, mycelial and sexual stages of Neurospora crassa. Fungal Genetics and Biology, v.21, p.348$363,1997$.

OKA, Y.; COHEN, Y. Induced resistance to cyst and root-knot nematodes in cereals by DL- $\beta$-amino-n-butyric acid. European Journal of Plant Pathology, v.107, n.2, p.219-227, 2001.

OKA, Y.; COHEN, Y.; SPIEGEL, Y. Local and systemic induced resistance to the root-knot nematode in tomato by DL- $\beta$-amino-n-butyric acid. Phytopathology, v.89, p.1138-1143, 1999.

OKINAKA, Y.; MIMORI, K.; TAKEO, K.; KITAMURA, S.; TAKEUCHI, Y.; YAMAOKA, N.; YOSHIKAWA, M. A structural model for the mechanisms of elicitor release from fungal cell walls by plant [beta]-1,3-endoglucanase. Plant Physiology, v.109, n.3, p.839-845, 1995.

OOSTENDORP, M.; KUNZ, W.; DIETRICH, B.; STAUB, T. Induced disease resistance in plants by chemicals. European Journal of Plant Pathology, v.107, p.19-28, 2001. 
OROBER, M.; SIEGRIST, J.; BUCHENAUER, H. Mechanisms of phosphateinduced disease resistance in cucumber. European Journal of Plant Pathology, v.108, n.4, p.345-353, 2002.

PAIVA, N.L.; EDWARDS, R.; SUN, Y.J.; HRAZDINA, G.; DIXON, R.A. Stress responses in alfalfa (Medicago sativa L.) 11. Molecular cloning and expression of alfalfa isoflavone reductase, a key enzyme of isoflavonoid phytoalexin biosynthesis. Plant Molecular Biology, v.17, n.4, p.653-667, 1991.

PAIVA, N.L.; SUN, Y.J.; DIXON, R.A.; VANETTEN, H.D.; HRAZDINA, G. Molecular cloning of isoflavone reductase from pea (Pisum sativum L.): evidence for a 3R- isoflavanone intermediate in (+)-pisatin biosynthesis. Archives of Biochemistry and Biophysics, v.312, n.2, p.501-510, 1994.

PAN, S.Q.; YE, X.S.; KUĆ, J. Association of $\beta$-1,3-glucanase activity and isoform pattern with systemic resistance to blue mould in tobacco induced by stem injection with Peronospora tabacina or leaf inoculation with tobacco mosaic virus. Physiological and Molecular Plant Pathology, v.39, p.25-39, 1991.

PANABIÈRES, F.; PONCHET, M.; ALLASIA, V.; CARDIN, L.; RICCI, P. Characterization of border species among Pythiaceae: several Pythium isolates produce elicitins, typical proteins from Phytophthora spp. Mycological Research, v.101, p.1459-1468, 1997.

PASCHOLATI, S.F. Potencial de Saccharomyces cerevisiae e outros agentes bióticos na proteção de plantas contra patógenos. Piracicaba, 1998. 123p. Tese (Livre-Docência) - Escola Superior de Agricultura "Luiz de Queiroz", Universidade de São Paulo.

PASCHOLATI, S.F.; STANGARLIN, J.R.; HOTO, F.V.; PICCININ, E.; OSSWALD, W. Efeito in vitro do ativador de defesa vegetal "BION" no crescimento micelial e na germinação de conídios de Colletotrichum graminicola. Fitopatologia Brasileira, v.23, p.266, 1998. Suplemento.

PASCUAL, S.; NOMBELA, G.; AVILES, M.; MUÑIZ, M. Induced resistance in tomato to whitefly Bemisia tabaci by Bion. International Organization for Biological Control IOBC/WPRS Bulletin, v.26, n.10, p.61-64, 2003. 
PAULI, H.H.; KUTCHAN, T.M. Molecular cloning and functional heterologous expression of two alleles encoding (S)-N-methylcoclaurine 3'-hydroxilase (CYP80B1), a new methyl jasmonate-inducible cytochrome P-450-dependent monooxygenase of benzylisoquinoline alkaloid biosynthesis. Plant Journal, v.13, n.6, p.793-801, 1998.

PEART, J.R.; LU, R.; SADANANDOM, A.; MALCUIT, I.; MOFFETT, P.; BRICE, D.C.; SCHAUSER, L.; JAGGARD, D.A.W.; XIAO, S.; COLEMAN, M.J.; DOW, M.; JONES, J.D.G.; SHIRASU, K.; BAULCOMBE, D.C. Ubiquitin ligase-associated protein SGT1 is required for host and nonhost disease resistance in plants. Proceedings of the National Academy of Sciences of the USA, v.99, n.16, p.10865-10869, 2002.

PELLINEN, R.I.; KORHONEN, M.-S.; TAURIAINEN, A.A.; PALVA, E.T.; KANGASJÄRVI, J. Hydrogen peroxide activates cell death and defense gene expression in birch. Plant Physiology, v.130, n.2, p.549-560, 2002.

PENG, J.-L.; DONG, H.-S.; DONG, H.-P.; DELANEY, T.P.; BONASERA, J.M.; BEER, S.V. Harpin-elicited hypersensitive cell death and pathogen resistance require the $N D R 1$ and EDS1 genes. Physiological and Molecular Plant Pathology, v.62, n.6, p.317-326, 2003.

PEREIRA, A.A.; MOURA, W. De M.; ZAMBOLIM, L.; SAKIYAMA, N.S.; CHAVES, G.M. Melhoramento genético do cafeeiro no estado de Minas Gerais cultivares lançados e em fase de obtenção. In: ZAMBOLIM, L. (Ed.) O estado da arte de tecnologias na produção de café. Viçosa: UFV, 2002. cap.7, p.253295.

PERNAS, M.; LÓPEZ-SOLANILLA, E.; SÁNCHEZ-MONGE, R.; SALCEDO, G.; RODRÍGUEZ-PALENZUELA, P. Antifungal activity of a plant cystatin. Molecular Plant-Microbe Interactions, v.12, p.624-627, 1999.

PIETERSE, C.M.J.; TON, J.; VAN LOON, L.C. Cross-talk between plant defense signaling pathways: boost or burden? AgBiotechNet, v.3, p.1-8, 2001a. 
PIETERSE, C.M.J.; VAN PELT, J.A.; VAN WEES, S.C.M.; TON, J.; LÉONKLOOSTERZIEL, K.M.; KEURENTJES, J.J.B.; VERHAGEN, B.W.M.; KNOESTER, M.; VAN DER SLUIS, I.; BAKKER, P.A.H.M.; VAN LOON, L.C. Rhizobacteria-mediated induced systemic resistance: triggering, signaling and expression. European Journal of Plant Pathology, v.107, p.51-61, 2001 b.

PIFFANELLI, P.; ZHOU, F.; CASAIS, C.; ORME, J.; JAROSCH, B.; SCHAFFRATH, U.; COLLINS, N.C.; PANSTRUGA, R.; SCHULZE-LEFERT, P. The barley MLO modulator of defense and cell death is responsive to biotic and abiotic stress stimuli. Plant Physiology, v.129, p.1076-1085, 2002.

RESENDE, M.L.V.; NOJOSA, G.B.A.; CAVALCANTI, L.S.; AGUILAR, M.A.G.; SILVA, L.H.C.P.; PEREZ, J.O.; ANDRADE, G.C.G.; CARVALHO, G.A.; CASTRO, R.M. Induction of resistance in cocoa against Crinipellis perniciosa and Verticillium dahliae by acibenzolar-S-methyl (ASM). Plant Pathology, v.51, n.5, p.621-628, 2002.

REUVENI, R.; AGAPOV, V.; REUVENI, M. Foliar spray of phosphates induces growth increase and systemic resistance to Puccinia sorghi in maize. Plant Pathology, v.43, p.245-250, 1994.

RICCI, P.; BONNET, P.; HUET, J.; SALLANTIN, M.; BEAUVAIS-CANTE, F.; BRUNETEAU, M.; BILlARD, V.; MICHEL, G.; PERNOLlET, J. Structure and activity of proteins from pathogenic fungi Phytophthora eliciting necrosis and acquired resistance in tobacco. European Journal of Biochemistry, v.183, p.555-563, 1989.

RIJO, L.; RODRIGUES JUNIOR, C.J. Processo de infecção da Hemileia vastatrix Berk. et Br. em cultivares suscetíveis e resistentes de Coffea arabica L. Garcia de Orta. Series Est. Agraria, v.5, n.1/2, p.23-24, 1978.

ROBY, D.; TOPPAN, A.; ESQUERRÉ-TUGAYÉ, M.T. Systemic induction of chitinase activity and resistance in melon plants upon fungal infection or elicitor treatment. Physiological and Molecular Plant Pathology, v.33, p.409-417, 1988. 
ROCHE DIAGNOSTICS GMBH. DIG application manual for filter hybridization. Mannheim, 2000. 225p.

RODRIGUES JUNIOR, C.J.; BETTENCOURT, A.J.; RIJO, L. Races of the pathogen and resistance to coffee rust. Annual Review of Phytopathology, v.13, p.49-70, 1975a.

RODRIGUES JUNIOR, C.J.; MEDEIROS，E.F.; LEWIS，B.G. Relationships between a phytoalexin-like response in coffee leaves (Coffea arabica L.) and compatibility with Hemileia vastatrix Berk. \& Br. Physiologic Plant Pathology, v.6, p.35-41, 1975 b.

ROJAS, M.L.; MONTES DE GÓMEZ, V.; OCAMPO, C.A. Stimulation of lipoxygenase activity in cotyledonary leaves of coffee reacting hypersensitively to the coffee leaf rust. Physiological and Molecular Plant Pathology, v.43, p.209219, 1993.

ROMEIS, T.; LUDWIG, A.A.; MARTIN, R.; JONES, J.D.G. Calcium-dependent protein kinases play an essential role in a plant defense response. The EMBO Journal, v.20, n.20, p.5556-5567, 2001.

ROSS, F.A. Systemic acquired resistance induced by localized virus infection in plants. Virology, v.14, p.340-358, 1961.

ROULIN, S.; BUCHALA, A.J. The induction of $\beta$-1,3-glucanase and other enzymes in groundnut leaves infected with Cercospora arachidicola. Physiological and Molecular Plant Pathology, v.46, p.471-489, 1995.

RUESS, W.; MÜLlER, K.; KNAUF-BEITER, G.; KUNZ, W.; STAUB, T. Plant activator CGA 245704: an innovative approach for disease control in cereals and tobacco. In: BRIGHTON CROP PROTECTION CONFERENCE - PEST AND DISEASES. Brighton, 1996. p.9-17. (Ciba's Contribution). 
RUSTÉRUCCI, C.; MONTILlet, J.-L.; AGNEL, J.-P.; BATTESTI, C.; ALONSO, B.; KNOLL, A.; BESSOULE, J.-J.; ETIENNE, P.; SUTY, L.; BLEIN, J.-P.; TRIANTAPHYLIDÈS, C. Involvement of lipoxygenase-dependent production of fatty acid hydroperoxides in the development of the hypersensitive cell death induced by cryptogein on tobacco leaves. The Journal of Biological Chemistry, v.274, n.51, p.36446-36455, 1999.

RYALS, J.A.; NEUENSCHWANDER, U.H.; WILLITS, M.G.; MOLINA, A.; STEINER, H-Y; HUNT, M.D. Systemic acquired resistance. The Plant Cell, v.8, n.10, p.1809-1819, 1996.

RYAN, C.A. Protease inhibitors genes in plants: genes for improving defenses against insects and pathogens. Annual Review of Phytopathology, v.28, p.425449, 1990.

RYAN, C.A. The systemin signaling pathway: differential activation of plant defensive genes. Biochimica et Biophysica Acta, v.1477, n.1-2, p.112-121, 2000.

SAMBROOK, J.; RUSSELL, D.W. Molecular cloning: a laboratory manual. 3.ed. New York: Cold Spring Harbor Laboratory Press, 2001. v.1, p.1.119-1.122.

SANGER, F.; NICKLEN, S.; COULSON, A.R. DNA sequencing with chainterminating inhibitors. Proceedings of the National Academy of Sciences of the USA, v.74, p.5463-5467, 1977.

SASABE, M.; TOYODA, K.; SHIRAISHI, T.; INAGAKI, Y.; ICHINOSE, Y. cDNA cloning and characterization of tobacco ABC transporter: NtPDR1 is a novel elicitor-responsive gene. FEBS Letters, v.518, p.164-168, 2002.

SCHAFFRATH, U.; SCHEINPFLUG, H.; REISENER, H.J. An elicitor from Pyricularia oryzae induces resistance responses in rice: Isolation, characterization and physiological properties. Physiological and Molecular Plant Pathology, V.46, p.293-307, 1995.

SCHALLER, A.; RYAN, C.A. Molecular cloning of a tomato leaf cDNA encoding an aspartic protease, a systemic wound response protein. Plant Molecular Biology, v.31, p.1073-1077, 1996. 
SCHENK, P.M.; KAZAN, K.; WILSON, I.; ANDERSON, J.P.; RICHMOND, T.; SOMERVILLE, S.C.; MANNERS, J.M. Coordinated plant defense responses in Arabidopsis revealed by microarray analysis. Proceedings of the National Academy of Sciences of the USA, v.97, n.21, p.11655-11660, 2000.

SCHRÖDER, M.; HAHLBROCK, K.; KOMBRINK, E. Temporal and spatial patterns of $\beta$-1,3-glucanase and chitinase induction in potato leaves infected by Phytophthora infestans. Plant Journal, v.2, p.161-172, 1992.

SEO, S.; SETO, H.; KOSHINO, H.; YOSHIDA, S.; OHASHI, Y. A diterpene as an endogenous signal for the activation of defense responses to infection with tobacco mosaic virus and wounding in tobacco. The Plant Cell, v.15, p.863-873, 2003.

SERA, T.; ALTEIA, M.Z.; PETEK, M.R. Melhoramento do cafeeiro: variedades melhoradas no Instituto Agronômico do Paraná (IAPAR). In: ZAMBOLIM, L. (Ed.) $\mathbf{O}$ estado da arte de tecnologias na produção de café. Viçosa: UFV, 2002. cap.6, p.217-251.

SESSA, G.; D’ASCENZO, M.; MARTIN, G.B. Thr38 and Ser198 are Pto autophosphorylation sites required for the AvrPto-Pto-mediated hypersensitive response. EMBO Journal, v.19, n.10, p.2257-2269, 2000.

SHETTY, N.P.; KRISTENSEN, B.K.; NEWMAN, M.-A.; MØLLER, K.; GREGERSEN, P.L.; JØRGENSEN, H.J.L. Association of hydrogen peroxide with restriction of Septoria tritici in resistant wheat. Physiological and Molecular Plant Pathology, v.62, n.6, p.333-346, 2003.

SIEGRIST, J.; OROBER, M.; BUCHENAUER, H. $\beta$-Aminobutyric acid-mediated enhancement of resistance in tobacco to tobacco mosaic virus depends on the accumulation of salicylic acid. Physiological and Molecular Plant Pathology, v.56, p.95-106, 2000.

SILUÉ, D.; PAJOT, E.; COHEN, Y. Induction of resistance to downy mildew (Peronospora parasitica) in cauliflower by DL- $\beta$-amino-n-butanoic acid (BABA). Plant Pathology, v.51, n.1, p.97-102, 2002. 
SILVA, M.C.; NICOLE, M.; RIJO, L.; GEIGER, J.P.; RODRIGUES JR., C.J. Cytochemical aspects of the plant rust fungus interface during the compatible interaction Coffea arabica (cv.Caturra) - Hemileia vastatrix (race III). International Journal of Plant Science, v.160, n.1, p.79-91, 1999.

SILVA, M.C.; NICOLE, M.; GUERRA-GUIMARÃES, L.; RODRIGUES JUNIOR, C.J. Hypersensitive cell death and post-haustorial defense responses arrest the orange rust (Hemileia vastatrix) growth in resistant coffee leaves. Physiological and Molecular Plant Pathology, v.60, n.4, p.169-183, 2002.

SILVA, M.C.; VÁRZEA, V.M.P.; MARQUES, D.V.; GUERRA-GUIMARÃES, L.; NICOLE, M.; COELHO, D.; GEIGER, J.P.; RODRIGUES JUNIOR, C.J. The role of peroxidase activity in the hypersensitive reaction of Coffea arabica plants with complete resistance to orange rust (Hemileia vastatrix). In: INTERNATIONAL SYMPOSIUM ON DURABLE RESISTANCE: KEY TO SUSTAINABLE AGRICULTURE, Ede-Wageningen, 2000. p.59.

SIVASANKAR, S.; SHELDRICK, B.; ROTHSTEIN, S.J. Expression of allene oxide synthase determines defense gene activation in tomato. Plant Physiology, v.122, p.1335-1342, 2000.

SLAYMAKER, D.H.; NAVARRE, D.A.; CLARK, D.; POZO, O.D.; MARTIN, G.B.; KLESSIG, D.F. The tobacco salicylic acid-binding protein 3 (SABP3) is the chloroplast carbonic anhydrase, which exhibits antioxidant activity and plays a role in the hypersensitive defense response. Proceedings of the National Academy of Sciences of the USA, v.99, n.18, p.11640-11645, 2002.

SMITH, R.F.; WIESE, B.A.; WOJZYNSKI, M.K.; DAVISON, D.B.; WORLEY, K.C. BCM Search Launcher--an integrated interface to molecular biology data base search and analysis services available on the World Wide Web. Genome Research, v.6, n.5, p.454-462, 1996.

SOLOMON, M.; BELENGHI, B.; DELLEDONNE, M.; MENACHEM, E.; LEVINE, A. The involvement of cysteine proteases and protease inhibitor genes in the regulation of programmed cell death in plants. The Plant Cell, v.11, p.431443, 1999. 
STADNIK, M.J.; BUCHENAUER, H. Inhibition of phenylalanine ammonia-lyase suppresses the resistance induced by benzothiadiazole in wheat to Blumeria graminis f.sp.tritici. Physiological and Molecular Plant Pathology, v.57, p.2534, 2000.

STANGARLIN, J.R.; PASCHOLATI, S.F. Atividades de ribulose-1,5-bifosfato carboxilase-oxigenase (rubisco), clorofilase, $\beta$-1,3-glucanase e quitinase e conteúdo de clorofila em cultivares de feijoeiro (Phaseolus vulgaris) infectados com Uromyces appendiculatus. Summa Phytopathologica, v.26, n.1, p.34-42, 2000.

STICHER, L.; MAUCH-MANI, B.; MÉTRAUX, J.-P. Systemic acquired resistance. Annual Review of Phytopathology, v.35, p.235-270, 1997.

STROBEL, N.E.; JI, C.; GOPALAN, S.; KUĆ, J.A.; HE, S.Y. Induction of systemic acquired resistance in cucumber by Pseudomonas syringae pv.syringae 61 HrpZ $_{\text {Pss }}$ protein. The Plant Journal, v.9, n.4, p.431-440, 1996.

SUO, Y.; LEUNG, D.W.M. ASM-induced accumulation of extracellular proteins and blackspot disease in rose. Biologia Plantarum, v.45, n.2, p.273-279, 2002.

TAKEMOTO, D.; HAYASHI, M.; DOKE, N.; MISHIMURA, M.; KAWAKITA, K. Isolation of the gene for EILP, an elicitor-inducible LRR receptor-like protein, from tobacco by differential display. Plant Cell Physiology, v.41, n.4, p.458464, 2000.

TAKEMOTO, D.; YOSHIOKA, H.; DOKE, N.; KAWAKITA, K. Disease stressinducible genes of tobacco: expression profile of elicitor-responsive genes isolated by subtractive hybridization. Physiologia Plantarum, v.118, p.545-553, 2003.

TALLY, A.; OOSTENDORP, M.; LAWTON, K.; STAUB, T.; BASSI, B. Commercial development of elicitors of induced resistance to pathogens. In: AGRAWAL, A.A.; TUZUN, S.; BENT, E. (Ed.) Induced plant defenses against pathogens and herbivores. Saint Paul: APS Press, 1999. p.357-369. 
THALER, J.S.; FIDANTSEF, A.L.; DUFFEY, S.S.; BOSTOCK, R.M. Tradeoffs in plant defense against pathogens and herbivores: a field demonstration using chemical elicitors of induced resistance. Journal of Chemical Ecology, v.25, p.1597-1609, 1999.

THALER, J.S.; STOUT, M.J.; KARBAN, R.; DUFFEY, S.S. Jasmonate-mediated induced plant resistance affects a community of herbivores. Ecological Entomology, v.26, n.3, p.312-324, 2001.

TREWAVAS, A. Signal perception and transduction. In: BUCHANAN, B.B.; GRUISSEM, W.; JONES, R.L. (Ed.) Biochemistry and molecular biology of plants. Rockville: American Society of Plant Biologists, 2000. chap.18, p.930987.

TRUERNIT, E.; SCHMID, J.; EPPLE, P.; ILLIG, J.; SAUER, N. The sink-specific and stress-regulated Arabidopsis STP4 gene: enhanced expression of a gene encoding a monosaccharide transporter by wounding, elicitors, and pathogen challenge. Plant Cell, v.8, n.12, p.2169-2182, 1996.

TUZUN, S. The relationship between pathogen-induced systemic resistance (ISR) and multigenic (horizontal) resistance in plants. European Journal of Plant Pathology, v.107, p.85-93, 2001.

UKNES, S.; MAUCH-MANI, B.; MOYER, M.; POTTER, S.; WILlIAMS, S.; DINCHER, S.; CHANDLER, D.; SLUSARENKO, A.; WARD, E.; RYALS, J. Acquired resistance in Arabidopsis. Plant Cell, v.4, p.645-656, 1992.

UMEMOTO, N.; KAKITANI, M.; IWAMATSU, A.; YOSHIKAWA, M.; YAMAOKA, N.; ISHIDA, I. The structure and function of a soybean $\beta$-glucanelicitor-binding protein. Proceedings of the National Academy of Sciences of the USA, v.94, p.1029-1034, 1997.

VAN LOON, L.C.; VAN STRIEN, E.A. The families of pathogenesis-related proteins, their activities, and comparative analysis of PR-1 type proteins. Physiological and Molecular Plant Pathology, v.55, p.85-97, 1999. 
VAN LOON, L.C.; BAKKER, P.A.H.M.; PIETERSE, C.M.J. Systemic resistance induced by rhizosphere bacteria. Annual Review of Phytopathology, v.36, p.453-483, 1998.

VAN LOON, L.C.; PIERPOINT, W.S.; BOLLER, Th.; CONEJERO, V. Recommendations for naming plant pathogenesis-related proteins. Plant Molecular Biology Reporter, v.12, n.3, p.245-264, 1994.

VAN WEES, S.C.M.; SWART, E.A.M.; VAN PELT, J.A.; VAN LOON, L.C.; PIETERSE, C.M.J. Enhancement of induced disease resistance by simultaneous activation of salicylate- and jasmonate-dependent defense pathways in Arabidopsis thaliana. Plant Biology, v.97, p.8711-8716, 2000.

VÁRZEA, V.M.P.; RODRIGUES JUNIOR, C.J.; SILVA, M. Do C.M.L.; GOUVEIA, M.; MARQUES, D.V.; GUERRA-GUIMARAES, L.; RIBEIRO, A. Resistência do cafeeiro a Hemileia vastatrix. In: ZAMBOLIM, L. (Ed.) O estado da arte de tecnologias na produção de café. Viçosa: UFV, 2002. cap.8, p.297-320.

VERNOOIJ, B.; FRIEDRICH, L.; AHL GOY, P.; STAUB, T.; KESSMANN, H.; RYALS, J. 2,6-Dichloroisonicotinic acid-induced resistance to pathogens without the accumulation of salicylic acid. Molecular Plant-Microbe Interactions, v.8, p.228-234, 1995.

VERNOOIJ, B.; FRIEDRICH, L.; MORSE, A.; REIST, R.; KOLDITZ-JAWHAR, R.; WARD, E.; UKNES, S.; KESSMANN, H.; RYALS, J. Salicylic acid is not the translocated signal responsible for inducing systemic acquired resistance but is required in signal transduction. Plant Cell, v.6, p.959-965, 1994.

WALTERS, D.; COWLEY, T.; MITCHELL, A. Methyl jasmonate alters polyamine metabolism and induces systemic protection against powdery mildew infection in barley seedlings. Journal of Experimental Botany, v.53, n.369, p.747-756, 2002.

WAN, J.; DUNNING, F.M.; BENT, A.F. Probing plant-pathogen interactions and downstream defense signaling using DNA microarrays. Functional and Integrative Genomics, v.2, p.259-273, 2002. 
WANG, Z.; BROWN, D.D. A gene expression screen. Proceedings of the National Academy of Sciences of the USA, v.88, p.11505-11509, 1991.

WARD, E.R.; UKNES, S.J.; WILLIAMS, S.C.; DINCHER, S.S.; WIEDERHOLD, D.L.; ALEXANDER, D.C.; AHL GOY, P.; MÉTRAUX, J.-P.; RYALS, J.A. Coordinate genes activity in response to agents that induce systemic acquired resistance. Plant Cell, v.3, p.1085-1094, 1991.

WASTERNACK, C.; PARTHIER, B. Jasmonate-signalled plant gene expression. Trends in Plant Science, v.2, n.8, p.302-307, 1997.

WEI, Z.M.; LABY, R.J.; ZUMOFF, C.H.; BAUER, D.W.; HE, S.Y.; COLLMER, A.; BEER, S.V. Harpin, elicitor of the hypersensitive response produced by the plant pathogen Erwinia amylovora. Science, v.257, p.85-88, 1992.

WILKINS, J.C.; HOMER, K.A.; BEIGHTON, D. Altered protein expression of Streptococcus oralis cultured at low $\mathrm{pH}$ revealed by two-dimensional gel electrophoresis. Applied and Environmental Microbiology, v.67, n.8, p.3396$3405,2001$.

WILKINS, M.R.; GASTEIGER, E.; BAIROCH, A.; SANCHEZ, J.-C.; WILLIAMS, K.L.; APPEL, R.D.; HOCHSTRASSER, D.F. Protein identification and analysis tools in the ExPASy server. In: LINK, A.J. (Ed.). 2-D Proteome Analysis Protocols. New Jersey: Humana Press, 1998.

WIRTH, S.J.; WOLF, G.A. Dye-labelled substrates for the assay and detection of chitinase and lysozyme activity. Journal of Microbiological Methods, v.12, p.197-205, 1990.

WIRTH, S.J.; WOLF, G.A. Micro-plate colorimetric assay for endo-acting cellulase, xylanase, chitinase, 1,3- $\beta$-glucanase and amylase extracted from forest soil horizons. Soil Biology and Biochemistry, v.24, p.511-519, 1992.

WÜSTEFELD, A. Etablierung und Charakterisierung von ReisZellsuspensionskulturen Untersuchungen zur Reis/Pyricularia oryzae-Interaktion unter den Aspekten Elicitorwirkung, Mycelapplikation und ChitinaseAktivierung. Aachen, 1993. 148p. Thesis (Doctor) - Rheinisch-Westfälischen Technischen Hochschule Aachen. 
XIAO, F.; TANG, X.; ZHOU, J.-M. Expression of 35S::Pto globally activates defense-related genes in tomato plants. Plant Physiology, v.126, p.1637-1645, 2001.

XIONG, L.; LEE, M.-W.; QI, M.; YANG, Y. Identification of defense-related rice genes by suppression subtractive hybridization and differential screening. Molecular Plant-Microbe Interactions, v.14, n.5, p.685-692, 2001.

YOSHIMURA, S.; YAMANOUCHI, U.; KATAYOSE, Y.; TOKI, S.; WANG, Z.X.; KONO, I.; KURATA, N.; YANO, M.; IWATA, N.; SASAKI, T. Expression of $X a 1$, a bacterial blight-resistance gene in rice, is induced by bacterial inoculation. Proceedings of the National Academy of Sciences of the USA, v.95, p.1663$1668,1998$.

YOUNG, D.H.; PEGG, G.F. The action of tomato and Verticillium albo-atrum glycosidases on the hyphal wall of V.albo-atrum. Physiological Plant Pathology, v.21, p.411-423, 1982.

YU, L.M. Elicitins from Phytophthora and basic resistance in tobacco. Proceedings of the National Academy of Sciences of the USA, v.92, p.4088-4094, 1995.

ZAMBOLIM, L.; VALE, F.X.R. do; COSTA, H.; PEREIRA, A.A.; CHAVES, G.M. Epidemiologia e controle integrado da ferrugem-do-cafeeiro. In: ZAMBOLIM, L. (Ed.) $\mathbf{O}$ estado da arte de tecnologias na produção de café. Viçosa: UFV, 2002. cap.10, p.369-450.

ZHANG, Y.; FAN, W.; KINKEMA, M.; LI, X.; DONG, X. Interaction of NPR1 with basic leucine zipper protein transcription factors that bind sequences required for salicylic acid induction of the PR-1 gene. Proceedings of the National Academy of Sciences of the USA, v.96, p.6523-6528, 1999.

ZHOU, J.-M.; TRIFA, Y.; SILVA, H.; PONTIER, D.; LAM, E.; SHAH, J.; KLESSIG, D.F. NPR1 differentially interacts with members of the TGA/OBF family of transcription factors that bind an element of the PR-1 gene required for induction by salicylic acid. Molecular Plant-Microbe Interactions, v.13, p.191202, 2000. 
ZHU, Q.; MAHER, E.A.; MASOUD, S.; DIXON, R.A.; LAMB, C.J. Enhanced protection against fungal attack by constitutive co-expression of chitinase and glucanase genes in transgenic tobacco. Bio/Technology, v.12, p.807-812, 1994.

ZIADI, S.; POUPARD, P.; BRISSET, M.-N.; PAULIN, J.-P.; SIMONEAU, P. Characterization in apple leaves of two subclasses of PR-10 transcripts inducible by acibenzolar-S-methyl, a functional analogue of salicylic acid. Physiological and Molecular Plant Pathology, v.59, p.33-43, 2001.

ZIEGLER, J.; KEINÄNEN, M.; BALDWIN, I.T. Herbivore-induced allene oxide synthase transcripts and jasmonic acid in Nicotiana attenuata. Phytochemistry, v.58, p.729-738, 2001.

ZIMMERLI, L.; JAKAB, G.; MÉTRAUX, J.-P.; MAUCH-MANI, B. Potentiation of pathogen-specific defense mechanisms in Arabidopsis by $\beta$-aminobutyric acid. Proceedings of the National Academy of Sciences of the USA, v.97, n.23, p.12920-12925, 2000.

ZUPPINI, A.; BALDAN, B.; MILLIONI, R.; FAVARON, F.; NAVAZIO, L.; MARIANI, P. Chitosan induces $\mathrm{Ca}^{2+}$-mediated programmed cell death in soybean cells. New Phytologist, v.161, n.2, p.557-568, 2004. 